Universidade de São Paulo

Faculdade de Filosofia, Letras e Ciências Humanas

Departamento de Letras Clássicas e Vernáculas

Programa de Pós-Graduação em Literatura Portuguesa

Ana Cristina Joaquim

\title{
O corpo, o corpus - poemas e interseções discursivas: Artur do Cruzeiro Seixas, Herberto Helder, Mário Cesariny de Vasconcelos
}


Universidade de São Paulo

Faculdade de Filosofia, Letras e Ciências Humanas

Departamento de Letras Clássicas e Vernáculas

Programa de Pós-Graduação em Literatura Portuguesa

Ana Cristina Joaquim

\section{O corpo, o corpus - poemas e interseções discursivas: Artur do Cruzeiro Seixas, Herberto Helder, Mário Cesariny de Vasconcelos}

Tese apresentada ao Programa de Pós-Graduação em Literatura Portuguesa, do Departamento de Letras Clássicas e Vernáculas da Faculdade de Filosofia Letras e Ciências Humanas - USP, para a obtenção do título de Doutora em Letras.

Orientadora: Prof ${ }^{a}$. Dra . Paola Poma

Co-orientador: Prof. Dr. Gustavo Maximiliano Florêncio Rubim 
Nome: Ana Cristina Joaquim

Título: O corpo, o corpus - poemas e intersecções discursivas: Artur do Cruzeiro Seixas, Herberto Helder, Mário Cesariny de Vasconcelos

Tese apresentada ao Programa de Pós-Graduação em Literatura Portuguesa, do Departamento de Letras Clássicas e Vernáculas da Faculdade de Filosofia Letras e Ciências Humanas - USP, para a obtenção do título de Doutora em Letras.

Aprovada em: de de 2016

Professora Doutora Paola Poma - USP - Orientadora

Professora Livre-Docente Mônica Muniz de Souza Simas - USP

Professor Doutor Jorge Fernandes da Silveira - UFRJ

Professor Doutor Luis Claudio Sant'Anna Maffei - UFF

Professor Livre-Docente Maurício Salles Vasconcelos - USP 


\section{AGRADECIMENTOS}

À Coordenação de Aperfeiçoamento de Pessoal de Nível Superior (CAPES) que ofereceu as condições materiais para execução do trabalho, sem as quais essa pesquisa não teria sido possível.

Aos professores Adma Fadul Muhana, Annie Gisele Fernandes, Horácio Costa, Mônica Simas e Maurício Salles Vasconcelos por terem solidificado minha formação intelectual, humana \& afetiva.

Aos professores Diana Pimentel, Emerson Inácio, Fernando Cabral Martins, Gustavo Rubim, Helder Macedo, Hélio Salles Gentil, Ida Ferreira Alves, Jerónimo Pizarro, Jorge Fernandes da Silveira (quem primeiramente me fez atentar para a extensão vocabular do "corpo" ao "corpus"...), Leonardo Gandolfi, Lilian Jacoto, Luis Maffei, Perfecto Cuadrado, Rafael Santana, Rosa Maria Martelo, Ricardo Vasconcelos e Sofia de Sousa Silva pela presença carinhosa e contribuições indispensáveis neste percurso.

À Cidália Fernandes, Constança Araújo Amador e demais funcionários da Fundação Cupertino de Miranda, que tão generosamente me receberam e me permitiram acessar o espólio ao abrigo da Fundação.

Aos colegas de jornada Bruno Anselmi Matangrano, Danilo Bueno, Gisele Candido, Karina Uehara, Leonardo de Barros, Natasha Furlan Felizi, Nathália Macri Nahas, Roberta Ferraz, Rui Daniel Nascimento e Sofia Santos pela delicada cumplicidade.

Aos amigos de muitas geografias \& afetos, que imensamente contribuíram para a construção do meu olhar: Amélia Loureiro, Ana Isabel Soares, Ana Pauline Lee, Antonio Vicente Seraphim Pietroforte, Bruna Muriel, Caetano Souto Maior, Camila Pierobon, Carlos Gregório Guerra, Caroline Moraes, Claudio Daniel, Danielle Grace Almeida, Érica Zíngano, Ernesto Melo e Castro, Horácio Costa, Inês Dias, Isadora Reimão, Júlia de Carvalho Hansen, Leonardo de Barros, Leonardo Gandolfi, Lucas Kiler, Manuel de Freitas, Marília Garcia, Marina Villarinho, Markinho Hourneaux, Maurício Salles Vasconcelos, Miguel de Carvalho, Milena de Moura Barba, Natália Ribeiro, Natasha Furlan Felizi, Paulo Aureliano da Mata, Paulo Jonas de Lima Piva, Rodrigo Ielpo, San Romanelli Assumpção, Tales Frey e Vanessa Nicolav.

Ao Cruzeiro Seixas por tudo o que fez, faz e fará na subversão das idades que nos (in)determinam.

Agradeço sobretudo à Paola Poma, minha orientadora, pela confiança, paciência, atenção, pela presença constante, pelas reflexões possíveis, pelo amparo e intensidades diversas.

À minha mãe e irmão pelo apoio incondicional: os meus melhores sentimentos. 
Le Mystère du corps et le Mystère du verbe sont le même, ils viennnent d'une incoercibilité qui se tord sur elle-même de bas en bas. ${ }^{1}$

Todo e qualquer trabalho situa-se, bem ou mal, numa geografia - de preferencia na intimidade de uma matéria, desde que haja uma reciproca: ele trabalha a matéria e é trabalhado por ela. ${ }^{2}$

No exercício rigoroso de sua atividade, a crítica haverá de convocar todos aqueles instrumentos que lhe pareçam úteis, mas não poderá jamais esquecer que a realidade sobre a qual se volta é uma realidade de signos, de linguagem portanto. ${ }^{3}$

(...) a instabilidade é talvez um dos condimentos mais importantes para a artisticidade da obra de arte, que só pode viver quando recebida por alguém preciso, individual, e dai instável, e não simplesmente fechada por uma interpretação, um valor, um sentido únicos, que almejam à estabilidade, à autoridade - à morte, em resumo. ${ }^{4}$

\footnotetext{
${ }^{1}$ ARTAUD, Antonin. Oevres complètes (vol. XVIII). Paris: Gallimard, 1983, p. 183.

${ }^{2}$ LIMA, Sergio Claudio de Fransceschi. O corpo significa. São Paulo: EDART, 1976, p. 5

${ }^{3}$ CAMPOS, Haroldo de. Metalinguagem \& outras metas. São Paulo: Perspectiva, 1992, p. 11.

${ }^{4}$ COSTA, Horácio. Entrevista concedida à Claudio Daniel In: Revista Coyote, Londrina: $\mathrm{n}^{\circ}$ 10, p. 26-36, primavera de 2004, p. 32.
} 


\section{RESUMO}

JOAQUIM, Ana Cristina. O corpo, o corpus - poemas e intersecções discursivas: Artur do Cruzeiro Seixas, Herberto Helder, Mário Cesariny de Vasconcelos. Tese (Doutorado) - Faculdade de Filosofia Letras e Ciências Humanas da Universidade de São Paulo, 2016.

Trata-se de uma intersecção entre as reflexões acerca da subjetividade e a poesia portuguesa escrita por três autores do século XX: Artur do Cruzeiro Seixas, Herberto Helder e Mário Cesariny de Vasconcelos. Tomando como ponto de partida as considerações acerca da subjetividade inscritas na modernidade filosófica - conforme estabelecidas pela filosofia cartesiana - a pesquisa tem por objetivo subverter a visada racionalista, mediante as diretrizes da fenomenologia de Maurice Merleau-Ponty, e promover um elo entre corpo perceptivo e sujeito poético. Para tanto, importa considerar de que modo as figurações do corpo contribuem, na poética dos três autores mencionados, para uma ideia de constituição subjetiva mediante a escrita poética. Tendo em vista a linguagem poética como constituinte subjetivo, faz-se necessário refletir acerca das dobras da linguagem e da metalinguagem implicada nos processos de subjetivação.

Palavras-chave: Poesia, Portugueses, Subjetividade, Fenomenologia, Metalinguagem. 


\begin{abstract}
JOAQUIM, Ana Cristina. The body, the corpus - poems and discursive intersections: Artur do Cruzeiro Seixas, Herberto Helder, Mário Cesariny de Vasconcelos. Tese (Doutorado) - Faculdade de Filosofia Letras e Ciências Humanas da Universidade de São Paulo, 2016.

This thesis proposes a theoretical approach that examines the intersection between the reflection of subjectivity and language, which I will analyze in the Portuguese poetry of twentieth century writers Artur do Cruzeiro Seixas, Herberto Helder and Mario Cesariny de Vasconcelos. Taking as a starting point, the philosophical debates over subjectivity as established by Cartesian philosophy, this paper aims to subvert its rationalism through the phenomenology guidelines of Maurice Merleau-Ponty. I promote a link between perceptive body and poetical subject. I argue that the body's figurations contribute to the poetics of the three authors mentioned and enables an idea of subjective constitution through poetical writing. Once the poetical language is considered as a subjective constituent, I then reflect on the folds of language and metalanguage implicated in the processes that constitute subjectivity.
\end{abstract}

Key-words: Poetry, Portuguese, Subjectivity, Phenomenology, Metalanguage. 


\section{SUMÁRIO}

1. Introdução.............................................................. 10

$1.1 \quad$ No século $\mathrm{XX}$, o corpo.......................................11

$1.2 \quad$ A partir da Modernidade, o sujeito.....................................17

2. Capítulo I - Os campos discursivos do corpo: a filosofia, a poesia...................21

2.1 Descartes e Merleau-Ponty: do anticorpo cartesiano ao corpo como mensurador do mundo

2.2 Herberto Helder, Mário Cesariny e Cruzeiro Seixas: o corpo in-scrito, o corpo ex-scrito (acrescido de algumas considerações contextuais)....................36

3. Capítulo II - O corpo na fundação do sujeito da escrita.................................73

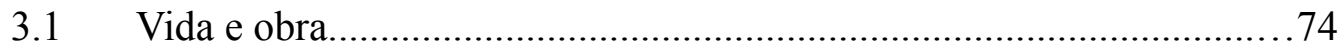

3.2 Herberto Helder e o nome-artesanato.................................................8 82

3.3 Mário Cesariny. e o nome porvir.......................................................101

3.4 Cruzeiro Seixas e o nome assombroso............................................121

3.5 Nomes e corpos, escritas de que percepção?......................................134

4. Capítulo III - A relação intercorpos............................................................138

4.1 O amor: argumento em favor da subversão.........................139

4.2 Herberto Helder e a gênese (gestação) do amor......................148

4.3 Mário Cesariny e o amor em trânsito..............................175

4.4 Cruzeiro Seixas e o amor transfonteiriço...........................192

4.5 Amor/amores de qual subjetividade?...........................209

5. Considerações Finais..................................................2 210

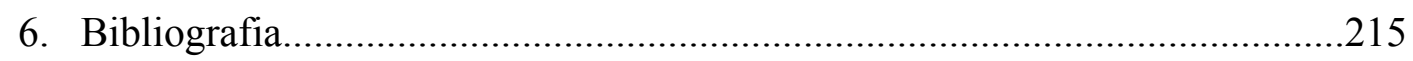

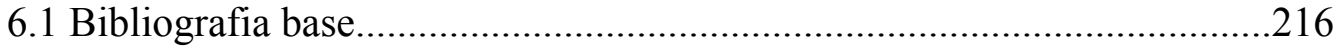

6.2 Bibliografia poético-literária (geral).................................219

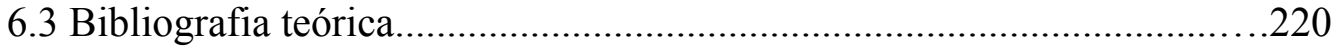




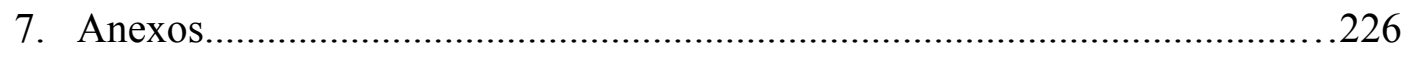
ANEXO A - Capa do Catálogo da Exposição do Grupo Surrealista de Lisboa............................................................... 227

ANEXO B - Na $1^{\mathrm{a}}$ Exposição de Cruzeiro Seixas em África.........................228 ANEXO C - Na 2a exposição de Cruzeiro Seixas Em África (15-24 - Jan. $57)$. 230

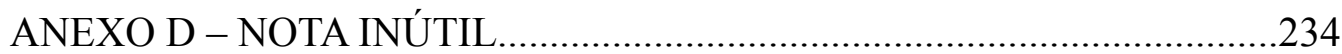

ANEXO E - Relance sobre a poesia de Edmundo de Bettencourt.................239

ANEXO F - Cena vocal com fundo visual de Cruzeiro Seixas....................253

ANEXO G - O Cadáver Esquisito e os estudantes........................................256

ANEXO H - Documento: censura de Apresentação do rosto.........................259

ANEXO I - Cesariny sombra de almagre....................................................260

ANEXO J - Cartaz da exposição de Cruzeiro Seixas na Galeria de Arte

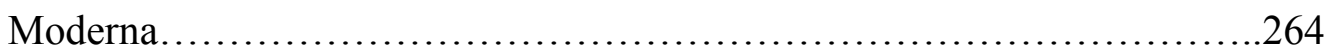


1. Introdução 


\subsection{No século XX, o corpo}

$\mathrm{O}$ século XX parece ter feito jus à materialidade como componente indissociável das formas de relação do homem com o mundo, consigo próprio, com os outros homens ${ }^{5}$. O corpo como traço de evidência de uma humanidade por muito tempo condicionada à metafísica - seja a metafísica da razão, seja a metafísica da religião - é, então, colocado em destaque de uma maneira muito própria: como eixo mesmo dessa humanidade, aspecto fundador de uma subjetividade que passa a ser pensada, a partir de então, em relação de complementaridade com a objetividade, como tentaremos mostrar . Essa "subjetividade encarnada" aparece com bastante evidência nas manifestações artísticas do século XX e, para fazer valer essa minha afirmação, eu poderia recorrer a diversas obras ou correntes artísticas em que o corpo e a sua materialidade são tópicos em evidência: um rápido olhar para a inauguração e para o enorme interesse que suscitou a arte da performance já seria argumento de peso, conforme atesta RoseLee Goldberg ${ }^{6}$. Para além disso, vale notar a variação inesgotável dos nus na fotografia - como atestam as obras do surrealista americano com carreira parisiense Man Ray, do alemão Hans Bellmer (com destaque, para além da fotografia, às suas ilustrações e bonecas, em que o corpo é decomposto e recomposto de maneira completamente inusitada), do húngaro Gyula Halász (mais conhecido pelo pseudônimo Brassaï) e do também húngaro André Kertész, em que os nus aparecem como imagens em distorção; ou o corpo encenado, nem sempre nu, da americana Diane Arbus. Os também inesgotáveis nus nas artes plásticas - e aqui a lista seria interminável, bastando

\footnotetext{
${ }^{5}$ É fato que a materialidade ou, mais especificamente, a importância do corpo variou historicamente de forma bastante complexa, sempre havendo a possibilidade de abordar determinada produção cultural inserida neste ou naquele momento histórico - a partir desse enfoque. Embora minha proposta de análise esteja circunscrita no modo como algumas manifestações artísticas (poéticas), situadas no século XX, revelam a centralidade do corpo como aspecto fundamental da constituição subjetiva, não me cabe caracterizar essa presença da materialidade como um aspecto inaugural, mas, tão somente, elucidá-la mediante suas peculiaridades nesse recorte de tempo em que se situam os poetas em questão e conversando, sempre que se faça conveniente, com a Modernidade Filosófica, momento em que o corpo está destituído de qualquer implicação subjetiva.

${ }^{6}$ Muito sucintamente, importa dizer que a performance foi aceita enquanto manifestação artística independente a partir da década de 70, momento em que o Futurismo e o Construtivismo russos vão focar o artista e seu corpo, sem que houvesse qualquer técnica regendo essa relação "arte-corpo" (diferenciando-se, vale dizer, de outras artes em que o corpo também estava em foco, como é o caso da dança ou do teatro). Antes de ser apropriada por artistas individuais - já na década de 90 - a performance é atualizada por outras vanguardas, como o Dadaísmo e a Bauhaus. Cf. GOLDBERG, Rose Lee. A arte da performance: Do Futurismo ao presente. São Paulo: Martins Fontes, 2006.
} 
mencionar algumas referências-chave como é o caso de Demoiselles D'Avignon, de Picasso, ou a série de nus de Modigliani, ou ainda o hiperrealismo escultural de Ron Mueck.

O corpo não se destaca, entretanto, apenas nas manifestações artísticas; o século XX francês também fomentou o pensamento filosófico acerca do corpo, que aparece evidenciado com bastante ênfase nas elaborações de pensadores tais como Michel Foucault: "Meu corpo é o contrário de uma utopia, é o que jamais se encontra sob outro céu, lugar absoluto, pequeno fragmento de espaço com o qual, no sentido estrito, faço corpo. Meu corpo, topia implacável."7, ou como Jean-Luc Nancy:

(...) o corpo dá lugar à existência. E dá lugar, muito precisamente, ao facto de que a existência tem por essência não ter nenhuma essência. É justamente por isso que a ontologia do corpo é a própria ontologia: o ser não é aqui qualquer coisa que preceda ou que esteja subjacente ao fenômeno. O corpo é o ser da existência ${ }^{8}$

em que o corpo assume posição central e é, por isso, centralizador de qualquer reflexão possível acerca da existência, única manifestação possível do ser. Também no pensamento pós-estruturalista e pós-psicanalista de Gilles Deleuze (de um certo modo, na esteira de Foucault), o corpo assume lugar de destaque. Deleuze, contra todas as fixações ideológicas operadas pelos discursos do poder instituído (o discurso religioso, o discurso pedagógico, o discurso médico...), vai falar no Corpo sem Órgãos, essa expressão tão diversa de qualquer metafísica, já que

não é de modo algum o contrário dos órgãos. $\mathrm{O}$ inimigo é o organismo. O CsO [Corpo sem Órgãos] não se opõe aos órgãos, mas a essa organização dos órgãos que se chama organismo (...). O organismo já é isto, o juízo de Deus, do qual os médicos se aproveitam e tiram seu poder. ${ }^{9}$

Tais modos de atenção acerca do corpo seriam, sem dúvida, vias possíveis de análise, sustentações para uma reflexão que encontra eco na materialização poética de uma diversidade imensa de poetas portugueses do século XX. Aqui novamente a lista

\footnotetext{
${ }^{7}$ FOUCAULT, Michel. O corpo utópico, as heterotopias. São Paulo: n-1 Edições, 2013, p.7.

${ }^{8}$ NANCY, Jean-Luc. Corpus. Lisboa: Vega, 2000, p. 16.

${ }^{9}$ DELEUZE, Gilles \& GATTARI, Félix. Mil platôs (vol.3). São Paulo: Editora 34, 2012, p. 24.
} 
seria infindável, basta uma breve mirada para os versos de Fiama Hasse Pais Brandão ${ }^{10}$ (notadamente aqueles de Matéria, de Enumeração da vista e do ouvido, de $O$ ar os tectos, mas também em poemas dispersos em livros vários como é o caso de "A minha mão fere-se na pedra...", de Visões mínimas, ou "Corpo cálido" de Homenagem à literatura); outra mirada para a poética de Luís Miguel Nava ${ }^{11}$, pela particularidade que ela apresenta ao agregar ao espírito, a matéria; e à matéria, o espírito, sem hierarquizações estabelecidas (Onde à nudez, O céu sob as entranhas); um olhar ainda para a poesia de Luiza Neto Jorge ${ }^{12}$ (especialmente em $A$ noite vertebrada e em $O s$ corpos vestidos) e para a poesia de Daniel Faria ${ }^{13}$, que parece reconhecer no corpo a possibilidade de comunicação com o divino (Homens que são como lugares mal situados, Mas basta-me um quadrado de sossego, Para encontrar o golpe no sono, Uma espécie de anjo ferido na raiz) e, por fim, numa visada menos ortodoxa e mais abrangente do ponto de vista da delimitação dos gêneros, interessaria muito pensar os pequenos verbetes de que se compõe o Atlas do corpo e da imaginação, de Gonçalo M. Tavares ${ }^{14}$.

Tais referências poderiam mesmo se expandir, de modo que os poetas que fizeram do corpo e da matéria, cada um a sua maneira, uma poética própria, comporiam uma lista inesgotável - e não apenas devido à recorrência de imagens corporais nas mais diversas manifestações poéticas do século XX (em português ou não...), mas devido, especialmente, a uma percepção de mundo e elaboração da escrita de caráter propriamente material, escrita essa que faz aparecer os órgãos do sentido e os membros do corpo como atestado da experiência vital que passa a ser o ato criativo: a organização escritural metaforizada pelo funcionamento biológico, eu arriscaria dizer. Num dos extremos dessa concepção, importa ainda mencionar a novidade trazida pela Poesia Experimental portuguesa, que - para citar apenas os mentores do movimento, Ernesto Manuel de Melo e Castro e Ana Hatherly ${ }^{15}$ - toma a materialidade

\footnotetext{
${ }^{10}$ Cf. BRANDÃO, Fiama Hasse Pais. Obra breve: poesia reunida. Lisboa: Assírio \& Alvim, 2006.

${ }^{11}$ Cf. NAVA, Luís Miguel. Poesia completa (1979-1994). Lisboa: Publicações Dom Quixote, 2002.

${ }^{12}$ Cf. JORGE, Luiza Neto. Poesia (1960-1989). Lisboa: Assírio \& Alvim, 2001.

${ }^{13}$ Cf. FARIA, Daniel. Poesia. Lisboa: Assírio \& Alvim, 2012.

${ }^{14}$ Cf. TAVARES, Gonçalo M. Atlas do corpo e da imaginação. Alfragide: Editorial Caminho, 2013.

${ }^{15}$ A PoEx (Poesia Experimental), foi um movimento que, como o Surrealismo, abarcou uma diversidade imensa de poetas. Importa mencionar aqui o nome de Herberto Helder que, além de ter assinado como
} 
como eixo próprio da escrita: esta passa a ser evidenciada pelos meios de que se utiliza, não sendo raros videopoemas, poemas visuais/plásticos, poemas sonoros; de forma que o olhar, a escuta e o movimento implicados na palavra - características sensoriais e, portanto, intimamente vinculadas ao corpo - estão articulados no modo "multimaterial" de composição poética. Em outras palavras, o corpo em particular e a matéria de modo geral, funcionam como elos relacionais significativos de uma concepção do humano que ultrapassa a visão puramente idealista.

$\mathrm{Na}$ mesma linha imagética e conceitual, se inscreve Herberto Helder que, de modo ainda mais enfático, situa o corpo nas reflexões sobre o próprio fazer poético. Os dois expoentes do surrealismo português que aqui elegemos para dialogar com Herberto Helder - Mário Cesariny de Vasconcelos e Arthur Manuel do Cruzeiro Seixas - se inscrevem nessa vertente de maneira menos declarada, no sentido de que o corpo não é "palavra engajada" como ocorre em Herberto Helder, isto é, não há um empenho tão evidente em associar o corpo ao fazer poético; embora, no caso da poesia surrealista portuguesa, nota-se não apenas a participação do corpo na maneira de mesclar sujeito e objeto (num procedimento semelhante àquele que descreve o pensamento fenomenológico, como veremos adiante), mas também a militância veemente contra os procedimentos lógicos da razão, o que redunda numa negação completa do pensamento cartesiano, que, conforme será evidenciado, exclui o corpo de qualquer participação nos elos filosóficos ali propostos.

A justificativa do recorte proposto passa, então, por uma relação de dupla abrangência: por um lado a abrangência do surrealismo enquanto movimento em Portugal, que abarcou (seja como atividade propriamente dita, seja como influência mais ou menos evidente), como veremos adiante, a prática de uma grande parte de poetas e artistas portugueses que dele se aproximaram de alguma maneira (vale frisar independentemente da adesão declarada - o caso de Herberto Helder, que em toda sua trajetória como poeta fez valer a liberdade subversiva tão aclamada pelos surrealistas sem jamais se declarar membro do movimento); por outro lado, a abrangência da temática corporal que, como aqui propomos, encontra sustentáculo mediante um olhar voltado para a história das ideias: pensar o corpo a partir de sua pertinência para o pensamento filosófico contribui para a elucidação do papel deste mesmo corpo no

organizador os dois números da revista Poesia Experimental, juntamente com António Aragão - outra personalidade bastante atuante no movimento PoEx -, ainda contribuiu com seis poemas visuais, que estão reproduzidos em: MARINHO, Maria de Fátima. Herberto Helder: a obra e o homem. Lisboa: Editora Arcádia, 1982, entre as páginas 104 e 105 (as reproduções não se encontram paginadas). 
modo de situar aquilo que, a partir da modernidade, recebe designação de maior importância: a subjetividade, o sujeito. Deste ponto de vista, ninguém melhor que Maurice Merleau-Ponty para traçar o percurso que nos interessa, uma vez que, ao situar a percepção como eixo motriz das suas reflexões, ele passa por uma negação do racionalismo cartesiano.

Descartes, como o maior representante do pensamento fundador da modernidade filosófica, inaugurou os modos de pensar e estabelecer a subjetividade mediante a operação racional. O texto cartesiano configura-se, portanto, como o antitexto do corpo, para nos apropriarmos de uma expressão utilizada por Pedro Eiras em ensaio dedicado a Herberto Helder, em que tece considerações acerca de sua poesia no confronto com o cartesianismo: "Trata-se de confrontar objetos. Para ler um texto, procurar os seus anti-textos, aquilo que ele nega, que ele manifestamente, aparentemente recusa." $" 16$.

Nesse mesmo sentido justificamos o corpo fenomenológico como um recorte que nos permite, além de traçar o seu anti-texto racionalista (sendo anti-textos racionalistas tanto o surrealismo quanto a poética herbertiana, para além do recorte temático que aqui propomos...), estabelecer um fluxo de leitura que se integra na materialidade. Claro esteja o caráter não exaustivo deste recorte no que se refere a uma abordagem dos poemas: também a metafísica (como a magia, o esoterismo, a ideia de psique componente do inconsciente...) poderia se configurar como um polo de leitura. Seriam, portanto, outros recortes possíveis que também encontrariam no racionalismo cartesiano seu anti-texto.

A metafísica por meio da magia, do esoterismo, do inconsciente e de sua manifestação no sonho, é tópico presente na poesia dos três autores em questão e não faltam ensaios críticos que abordam a poesia de Herberto Helder, de Cesariny e de Cruzeiro Seixas a partir de, pelo menos, uma das tradições metafísicas listadas acima. No caso de Herberto Helder, eu mencionaria dois longos estudos em que a metafísica é colocada no centro das investigações sobre a sua poética: fruto de uma pesquisa levada a cabo pela Prof ${ }^{a}$ Maria Lúcia Dal Farra, A alquimia da linguagem: leitura da cosmogonia poética de Herberto Helder, publicado em 1986 pela Imprensa NacionalCasa da Moeda, que é, muito mais do que uma leitura puramente idealista, uma feliz conjunção entre a materialidade e a metafísica operada pelas possibilidades que a

\footnotetext{
${ }^{16}$ EIRAS, Pedro. "A pedra na cabeça. Herberto Helder, René Descartes, uma questão de loucura". In: Textos pretextos, número 17, outono/inverno 2012, p.20-29, p. 21.
} 
leitura alquímica oferece; e, por um caminho mais voltado para a magia e o rito, $A$ obra ao rubro de Herberto Helder, de Maria Estela Guedes, publicado, em 2010, pela Editora Escrituras - que, entretanto, também encontra na alquimia alguma justificativa de abordagem. No caso de Cesariny, eu poderia mencionar os diversos estudos e ensaios produzidos por António Candido Franco, mas me atenho àquele em que a investida na metafísica ocorre com maior veemência: Notas para a compreensão do surrealismo em Portugal, publicado pela Licorne, sem especificação do ano ${ }^{17}$. Com o intuito de reforçar o elo entre Teixeira de Pascoaes e o surrealismo português (na esteira de Cesariny), a metafísica é aqui de tal modo assumida como via única de abordagem, que não apenas grande parte da tradição esotérica é reivindicada em consonância com a psicanálise freudiana (o inconsciente é visto como uma porta para o “além mundo"), mas o método mesmo de investigação se vale do transcendente, não sendo raras associações interpretativas justificadas por sonhos que teve António Candido Franco. No caso de Cruzeiro Seixas, dada a escassez de discursos críticos acerca de sua poesia (ele é muito mais conhecido pela obra plástica do que pela poética), me restrinjo a mencionar um pequeno texto publicado por Valter Hugo Mãe no Jornal de Letras e Artes em fevereiro de 2014, em que o escritor afirma que "Os corpos" do mestre Artur do Cruzeiro Seixas "são sobretudo alusões a corpos e não garantias de fisicalidade" e mais adiante: "De algum modo, o visionarismo de Artur do Cruzeiro Seixas é uma espiritualidade exercida a vida inteira. O seu surrealismo é uma manifestação da disciplina natural do espírito". ${ }^{18}$

Este recorte, portanto, reflete uma escolha (e, como toda escolha, há que se assumir os limites que dela advém...), uma escolha temática que é, de algum modo, um engajamento, uma vez que pretende valorizar essa via corporal de acesso ao mundo e ao ser. Tais limites no entanto não significam que, ao colocar o corpo em evidência, eu estaria recusando a presença das metafísicas envolvidas nos poemas, de maneira que, vez ou outra, se faz necessário reivindicá-las na leitura e perscrutar de que modo elas confirmam ou se relacionam com a evidenciação do corpo.

\footnotetext{
${ }^{17}$ Sabe-se, pela leitura do texto, que foi publicado posteriormente a Teixeira de Pascoaes nas Palavras do Surrealismo em Português, de 2010.

${ }^{18}$ MÃE, Valter Hugo. “Cruzeiro Seixas”. Jornal de Letras e Artes, 19 de fevereiro de 2014.
} 


\subsection{A partir da modernidade, a subjetividade}

Desde a tomada de partido a favor do racionalismo pela modernidade, a subjetividade passa a ser um conceito chave para lidar com questões históricas, sociais, ético/morais e epistemológicas. A reviravolta econômico-social que acompanha esse pensamento acerca da subjetividade - a saber, o declínio da aristocracia e a ascendência de uma nova classe social: a burguesia, que trouxe consigo uma nova maneira de organização social em que, noções de privacidade e individualidade permeiam as relações familiares, afetivas e profissionais -, coincide com o mote filosófico adequado a tais modificações econômico-sociais, isto é, o surgimento do racionalismo, (fins do século XVI) que acaba por redundar no Iluminismo (século XVIII) com o estabelecimento da sociedade burguesa. O racionalismo apresenta-se, nesse momento, como uma tentativa de superação das incertezas (na tradição filosófica, muito marcada pela escola cética) e consequente busca das certezas científicas universais. É nesse contexto que o racionalismo se estabelece como orientação de pensamento que tem na subjetividade o seu ponto de partida para a elaboração de uma perspectiva totalizante acerca do homem e da sua participação no logos universal.

Depois de séculos dominado pelo racionalismo nos moldes que serão expostos a seguir, o pensamento filosófico adota uma postura de investigação em que a subjetividade é considerada não apenas mediante uma operação da razão, mas também como resultado de uma operação da percepção, de forma que as reflexões acerca do corpo assumem evidente importância. Já no século XIX a fenomenologia surge como alternativa de abordagem: a subjetividade só pode ser pensada em relação à objetividade, isto é, sujeito e objeto são parte de um mesmo ciclo de conhecimento, deixando, portanto, de figurar como noções opostas.

Partindo dessas considerações, que desenvolverei devidamente adiante, trata-se, então, de fazer um breve percurso histórico acerca da ideia de subjetividade, passando por Descartes e Merleau-Ponty (capítulo I) - os dois grandes nomes no que se refere à problemática em questão, respectivamente, "anti-texto" e "co-texto" em relação aos poetas que colocamos em evidência - para pensar o papel que o corpo desempenha em cada um desses momentos. Trata-se ainda, neste mesmo capítulo, de apresentar o contexto de atuação escrita de cada um dos autores (com especial ênfase para a relação que mantiveram com o surrealismo), bem como de percorrer os discursos extra- 
poéticos - e por "discursos extra-poéticos", entendemos toda forma de manifestação escrita que, mesmo que se refira à criação poética ou artística, não seja veiculada em forma de poesia, sendo eles cartas, ensaios críticos, manifestos, panfletos, entrevistas, etc. - que permeiam a produção poética dos três autores, com especial ênfase para os diálogos que mantiveram entre si e para a evidenciação do corpo como eixo de reflexão poética.

A seguir, trataremos de pensar a "subjetividade encarnada", tal como se elabora pela escrita na poesia de Herberto Helder, Mário Cesariny e Cruzeiro Seixas (capítulo II). Investigaremos de que modo, mediante uma conjunção entre corpo e texto, "vida e obra", se desenha uma nova maneira de estabelecimento identitário. A discussão que permeia a relação entre vida e obra ganha, então, uma dimensão propriamente material e metalinguística, no sentido de que, nos três poetas, predomina uma visada da escrita como função corporal, ou seja, como uma forma de vida encarnada e constantemente evocada mediante processos que chamam atenção para a explicitação da linguagem. A recorrente figurativização do corpo e a explicitação metalinguística passam a ser catalizadoras dessa relação entre vida e obra. Conforme Rosa Maria Martelo em ensaio dedicado à confrontar as poéticas de Eugénio de Andrade e Fernando Pessoa, me dedico a uma leitura que contemple as “(...) três vertentes distintas da presença do corpo na escrita: a tematização do corpo (1), a inclusão de uma representação do corpo na construção da subjectividade (2) e o reconhecimento da actuação do corpo no processo criativo da escrita poética (3).". 19

No capítulo final (capítulo III), trata-se de pensar os modos de relação intercorpos - o corpo próprio e os outros corpos, com ênfase para o amor como eixo relacional, considerando-se, o amor erótico e as relações de gênero, mas não apenas: trata-se de considerar o amor como catalizador também das relações nacionais e raciais.

A seleção dos poetas para a presente pesquisa foi motivada pelo possível estabelecimento de uma cena de escrita, a princípio delimitada pelo diálogo mantido entre Herberto Helder e Mário Cesariny, entre Herberto Helder e Cruzeiro Seixas e entre Cesariny e Cruzeiro Seixas, ainda que tenham sido diálogos pontuais e espaçados no tempo. Se, por um lado, a poesia de Herberto Helder tem sido amplamente debatida

${ }^{19}$ MARTELO, Rosa Maria. "O corpo e corpus: Eugénio de Andrade vs. Pessoa (e outros caminhos" In: Em parte incerta, estudos de poesia portuguesa moderna e contemporânea. Porto: Campo das Letras, 2004, p. 135. 
nos meios de difusão poética - dada a força inescapável de sua sintaxe, bem como a coerência ( de um estilo peculiar -, e Mário Cesariny, apenas muito recentemente, tem sido alvo de maior interesse, Cruzeiro Seixas é, diferentemente, pouquíssimo (re)conhecido como poeta. Tendo estes fatores em vista, colocar estes três poetas lado a lado, resulta de um empenho, possibilitado pelo recorte temático, de dar voz à elaboração de um modo de subjetividade poética em grande parte compartilhada pelos três poetas supracitados (cuja ênfase do recorte que proponho recai no corpo), que, embora não equivalham no quesito "visibilidade acadêmica ou midiática", sem dúvida são, cada um a sua maneira, donos de uma poética consistente o bastante para que seja possível considerá-los sob o prisma de uma pesquisa acadêmica. Soma-se a isso o fato de que as criações resultantes dos diversos poetas e artistas envolvidos com o surrealismo em Portugal são mais ou menos irregulares em extensão quantitativa e temporal (com evidente exceção para o caso de Mário Cesariny e Cruzeiro Seixas o que justifica, portanto, a presente escolha), e, muito embora essa pesquisa não se pretenda uma abordagem do surrealismo Português - e menos ainda tenha como objetivo uma "leitura surrealista" dos surrealistas aqui eleitos (também por esse motivo não me atenho mais pormenorizadamente sobre os procedimentos de criação surrealistas, que inclusive já foram debatidos e divulgados suficientemente e não possibilitam qualquer ganho interpretativo para além de um certo didatismo implicado na decodificação de um modus operandi. Ademais, conforme as palavras de Fernando Martinho: "Uma coisa são as regras definidas pela poética surrealista para a decifração dos seus textos; outra, a posição do leitor que dificilmente poderá prescindir dos instrumentos de análise que utiliza para outros textos." ${ }^{20}$ ) -, não seria possível ignorar a força de um movimento que desencadeou grande debate na criação e na crítica ao longo da segunda metade do século XX português.

No que se refere à seleção do corpus poético, obedece ao recorte temático (e, portanto, está subsumida à temática da subjetividade encarnada e adjacências possíveis), de modo que não há privilégio de uma obra específica ou de um único poema de cada um dos autores, tampouco se privilegia uma fase em especial, mas, ao contrário, há o intuito de mostrar que a figurativização do corpo perpassa os vários momentos de elaboração criativa em cada um dos poetas. Nesse sentido, trata-se de um

\footnotetext{
${ }^{20}$ MARTINHO, Fernando J. B. Tendências dominantes da poesia portuguesa da década de 50. Lisboa: Edições Colibri, 2013 (2 edição), p. 45.
} 
caminho de abordagem menos ortodoxo, uma vez que não persegue uma cronologia ou uma noção de "conjunto", no mais das vezes pautada por uma publicação específica.

Pretendo, por meio deste percurso, perceber de que modo a poesia - ancorada pela abordagem filosófica que elegi como possibilidade de diálogo - permite uma reelaboração dos modos perceptivos, resultando numa proposta de revisitação dos olhares para o mundo e para o ser, em que o corpo assume lugar de destaque. 
2. Capítulo I:

Os campos discursivos do corpo: a filosofia, a poesia 


\subsection{Descartes e Merleau-Ponty: do anticorpo cartesiano ao corpo como mensurador do mundo}

\section{(...) fora do pensamento não há nada que seja ou exista verdadeiramente ${ }^{21}$}

Não existem problemas dominantes ou problemas subordinados: todos os problemas são concêntricos. ${ }^{22}$

A teoria fenomenológica de Maurice Merleau-Ponty apresenta-se na história das ideias como uma resposta à teoria cartesiana, cujos termos residem com bastante ênfase numa tentativa de conferir ao corpo o espaço de importância que lhe é devido nas reflexões epistemológicas e, em alguma medida, socioculturais. O sujeito cartesiano é, como poderemos ver no confronto das teorias, um sujeito desprovido do corpo naquilo que lhe seria mais próprio: a sua materialidade. Seu pensamento é guiado pura e simplesmente pelo aparato dedutivo que a razão analítica é capaz de conceber obedecendo fielmente aos princípios da lógica tradicional.

$\mathrm{O}$ corpo do qual nos fala Merleau-Ponty, em nada se assemelha à res extensa em Descartes. Explico: a filosofia cartesiana é essencialmente dualista, ou seja, há a admissão da existência de duas realidades completamente distintas: a alma substância pensante, e o corpo - substância extensa. Esse dualismo significa, portanto, a separação entre sujeito (alma = substância pensante/ res cogitans) e objeto $($ corpo = substância extensa/ res extensa).

Como decorrência de grande interesse, o dualismo cartesiano confere importâncias diversas para uma e outra substancia: Descartes defende a precedência do sujeito em relação ao objeto (isto é, em relação ao mundo, aos outros seres, ou àquilo que na sua filosofia pode ser entendido como a realidade objetiva), havendo assim uma independência do sujeito, de modo que apenas o sujeito pensante (alma) é capaz de atingir e ordenar o conhecimento. A partir disso, tudo passa a depender de demonstração intelectual - incluindo-se aí, a existência do mundo material e a realidade que lhe é própria. O próprio sujeito pensante garante como provável (isto é, passível de ser provado) a existência dos objetos. Ainda, segundo essa linha de

\footnotetext{
${ }^{21}$ DESCARTES, René. Princípios da Filosofia. Lisboa: Edições 70, 1997, p. 29.

${ }^{22}$ MERLEAU-PONTY. Maurice. Fenomenologia da percepção. São Paulo: Martins Fontes, 1996, p. 550.
} 
pensamento, tudo o que temos primeiramente são as nossas representações mentais (antes mesmo de qualquer experiência) e mediante as nossas representações é que iremos atestar a realidade.

A justificativa maior do pensamento cartesiano em relação à precedência da res cogitans sobre a res extensa se dá por um método: o exercício da dúvida. A dúvida é, entretanto, provisória, apenas um meio para a obtenção da verdade, por fim atingida, indubitável. A grande descoberta alcançada pelo pensamento mediante tal procedimento é a existência subjetiva em si mesma. Ora, o exercício da dúvida, por si só, revela uma existência indubitável: a existência do pensamento, ou seja, mediante o pensamento é que se torna possível o exercício da dúvida (dúvida $=$ ato do pensamento), o que permitiria concluir a existência do pensamento/sujeito.

(...) enquanto eu desejava considerar assim tudo como sendo falso, era obrigatório que eu, ao pensar, fosse alguma coisa. Percebi, então, que a verdade penso, logo existo era tão sólida e tão exata que sequer as mais extravagantes suposições dos céticos conseguiriam abalálas. $^{23}$

Há, dessa maneira, uma afirmação da existência do próprio sujeito enquanto ser pensante. Daí a conclusão: Cogito, ergo sum. Importa enfatizar que, ao estabelecer a existência do pensamento, ele está estabelecendo também a existência do ser, que se define enquanto aquele que pensa, de modo que o ser é o próprio pensamento.

Nota-se, mediante a dedução acima, que apenas o pensamento pode assegurar a existência, isto é, seguindo essa esteira de raciocínio, se qualquer outra função daquilo que supomos ser EU, fosse tomada como eixo para concluir a MINHA existência, não seria possível alcançar a mesma certeza. Por exemplo, se tomo como eixo a respiração e digo "Respiro, logo existo", eu teria de ser capaz de provar o ato de respiração apenas por meio da razão (a experiência sensorial da respiração, isto é, o argumento empírico, não tem valor no sistema cartesiano, já que a experiência nem sempre é regular, podendo ocorrer de maneira diversa daquela que prevemos, estando ela sujeita a falhas e a exceções). Entretanto se eu dissesse: "Penso que respiro, logo existo", então seria possível assegurar a minha existência, já que a atenção recairia, nesse caso, sobre o ato de pensar, este sim indubitável. O mesmo ocorre se eu agregar o termo "penso" a qualquer outra minha representação ou a qualquer outra função daquilo que acredite ser EU: "Penso que me movimento, logo existo", ou ainda, "Penso que tenho

\footnotetext{
${ }^{23}$ DESCARTES, René. Discurso sobre o método. São Paulo: Hemus Editora, s/d, p. 66-67.
} 
um corpo, logo existo", etc. No limite, a proposição "Penso, logo existo" tem o valor da proposição: "Existo enquanto penso", o que torna o ato de pensar a possibilidade de assegurar a minha existência.

A extensão, entretanto, assim como o pensamento, também seria uma característica essencial do ser, de acordo com a sua proposta dualista. E por essencial, entendemos qualquer substância, ou seja, algo que subsiste, existe por si próprio e, portanto, não depende de nada além de si mesmo para existir. Em outras palavras também a extensão constituiria o ser enquanto ser que existe, porém, não caberia a ela assegurar a existência:

(...) concluí de tudo isso que eu era, uma substância cuja essência ou natureza reside unicamente em pensar e que, para que exista, não necessita de lugar algum nem depende de nada material, de modo que eu, isto é, a alma, pela qual sou o que sou, é totalmente diversa do corpo e mesmo mais fácil de ser reconhecida do que este e, ainda que, se o corpo não existisse, ela não deixaria de ser tudo o que é. ${ }^{24}$

Embora essa deficiência da res extensa diante da res cogitans, a essencialidade com a qual a extensão é conotada em Descartes, permite não apenas assegurar a perspectiva racionalista, como condenar qualquer possibilidade de leitura em que esteja implicada a sua materialidade: a extensão é uma essência e, portanto, uma ideia (já que nenhum valor de verdade pode advir da experiência), ou seja, o corpo, a matéria, naquilo que têm de essencial, são conhecidos pelo entendimento e não pelos sentidos. De acordo com Franklin Leopoldo e Silva:

(...) Descartes não comete incoerência quando afirma que, embora o mundo material exista, ele não pode ser efetivamente conhecido enquanto tal, isto é, as percepções de corpos não podem tornar-se ideias objetivas. É como se necessitássemos menos da existência das coisas materiais do que do conceito de coisas materiais. Ora, esse conceito não constitui problemas porque é um ente matemático: a extensão pura e simplesmente geométrica. ${ }^{25}$

O corpo em Merleau-Ponty, muito diversamente, é um corpo em relação, pois que situado num mundo que já está dado antes da reflexão, isto é, o mundo não depende de nenhuma garantia do pensamento para que tenha sua existência

\footnotetext{
${ }^{24}$ Idem, p. 67.

${ }^{25}$ SILVA. Franklin Leopoldo e. Descartes: a metafisica da modernidade. São Paulo: Editora Moderna, 1993, p. 78.
} 
comprovada, de forma que a sua teoria é, portanto, uma tentativa de compreensão do homem e do mundo mediante a sua facticidade: não busca as origens, tampouco o conhecimento absoluto e verdadeiro ${ }^{26}$. A sua filosofia não se ocupa com a clareza e distinção ${ }^{27}$ oferecidas pela evidência racional, mas propõe uma investigação do ser mediante a condição factual que o determina, sendo o corpo, portanto, componente primordial da sua teoria. Isso não significa, como veremos, uma desconsideração da razão; ao contrário: significa considerá-la inserida numa rede de relações sem a qual seria impossível atestar a existência do indivíduo.

Prevalece, portanto, a noção do ser em situação e tendo em conta a facticidade como eixo de compressão do homem e do mundo (um eixo, portanto, relacional), o Cogito cartesiano sofre aqui uma reviravolta:

O Cogito deve revelar-me em situação (...). O verdadeiro Cogito não define a existência do sujeito pelo pensamento de existir que ele tem, não converte a certeza do mundo em certeza do pensamento do mundo e, enfim, não substitui o próprio mundo pela significação mundo. Ele reconhece, ao contrário, meu próprio pensamento como fato inalienável, e elimina qualquer espécie de idealismo revelandome como "ser no mundo". ${ }^{28}$

Dessa constatação segue-se o rompimento com a desconfiança de Descartes quanto à validade do mundo percebido (e a consequente desvalorização da percepção enquanto fundamento do conhecimento), uma vez que o mundo, bem como a minha

\footnotetext{
${ }^{26} \mathrm{O}$ conhecimento verdadeiro, de acordo com Descartes, só pode ser obtido dedutivamente, isto é, por meio da razão, já que os nossos sentidos, ao contrário do que defendem os empiristas, não seriam fiáveis, pois a experiência estaria sujeita às contingências diversas de tempo e de espaço: “(...) a experiência nos mostrou que os sentidos nos enganaram em várias ocasiões, e por isso seria imprudência confiar demasiado naqueles que já nos enganaram, mesmo que tivesse sido só uma vez, como também porque quando dormimos sonhamos quase sempre, e então parece-nos que sentimos vivamente e imaginamos claramente uma infinidade de coisas que não se encontram onde as supomos" (DESCARTES, René. Princípios da Filosofia. Lisboa: Edições 70, 1997, p.28). As ideias que temos dos objetos sensíveis - objetos exteriores dos quais formulamos representações a partir da experiência sensível - prestar-se-iam bem à incerteza, pois seriam instáveis e obscuras, mas as ideias matemáticas ('figura' e 'número'), de forma diversa, seriam claras e distintas, isto é, todos a conceberiam do mesmo modo: “(...) entre todos que, antes de mim, buscaram a verdade nas ciências, somente os matemáticos conseguiram encontrar algumas demonstrações, quero dizer, certas razões claras e evidentes" (DESCARTES, René. Discurso sobre o método. São Paulo: Hemus Editora, s/d, p. 41). Tais 'razões' seriam, de acordo com Descartes, ideias inatas, ou seja, ideias que nascem conosco, que subsistem em nós e que são imutáveis e universais e, portanto, seriam ideias verdadeiras, sobre as quais não haveria dúvida.
}

${ }^{27}$ Conforme Descartes afirma em Princípios da filosofia: "Chamo conhecimento claro àquilo que é manifesto a um espírito atento (...). E o conhecimento distinto é aquela apreensão de tal modo precisa e diferente de todas as outras que só compreende em si aquilo que lhe aparece manifestamente àquele que a considera de modo adequado.” (DESCARTES, René. Princípios da Filosofia. Lisboa: Edições 70, 1997, p. 7).

${ }^{28}$ MERLEAU-PONTY. Maurice. Fenomenologia da percepção. São Paulo: Martins Fontes, 1996, p. 9. 
existência, não seriam meramente evidencias oferecidas pelo meu pensamento, mas situação pela qual estou condicionado, ou seja: o mundo e a existência não mais assegurados pela reflexão, mas pela vivência, de forma que não há espaço, na fenomenologia, para a metafísica racionalista.

A evidência do mundo deixa de ser caracterizada pelo seu valor de verdade (aquela verdade tão perseguida pelo método cartesiano), e o seu estatuto passa a ser medido, desse ponto de vista, pura e simplesmente pela percepção inquestionável que temos dele: “(...) não é preciso perguntar-se se nós percebemos verdadeiramente um mundo, é preciso dizer, ao contrário: o mundo é aquilo que nós percebemos" ${ }^{29}$. Ao 'abandonar' a verdade absoluta enquanto objetivo obsessivamente perseguido pela vertente racionalista, Merleau-Ponty flexibiliza as noções de mundo subjetivo e mundo objetivo, uma vez que a existência não pode ser considerada apartada daquilo que a rodeia, ou melhor, aquilo que a rodeia é também aquilo que a evidencia e a constitui:

A aquisição mais importante da fenomenologia foi sem dúvida ter unido o extremo subjetivismo ao extremo objetivismo em sua noção do mundo ou da racionalidade. A racionalidade é exatamente proporcional às experiências nas quais ela se revela. Existe racionalidade, quer dizer: as perspectivas se confrontam, as percepções se confirmam, um sentido aparece. Mas ele não deve ser posto à parte, transformado em Espírito absoluto ou em mundo no sentido realista. ${ }^{30}$

A razão atua, desse modo, juntamente com a experiência e a percepção é o resultado dessa intersecção entre subjetividade e objetividade. A percepção, assim colocada no centro das investigações epistemológicas, desmitifica a razão enquanto via única para o desvelamento do sentido, como queriam os racionalistas; ou melhor: o sentido não é sequer algo a ser desvelado, mas ele é construído pela própria percepção, ou seja, a experiência é ela mesma mediada pelo corpo. Dessa perspectiva, não haveria uma verdade absoluta e única a ser desvelada, mas um sentido que emanaria da nossa capacidade/disponibilidade perceptiva, por assim dizer, de modo que a desmitificação da razão ganha contornos ainda mais extensos desse ponto de vista. A nossa necessária adesão ao mundo enquanto seres em situação não permite que qualquer investigação seja feita sem considerar essa implicação; em outras palavras: não seria possível isolar a razão com o objetivo de "olhar para fora", posto que somos implicados e constituídos

\footnotetext{
${ }^{29}$ Idem, pp, 13, 14.

${ }^{30}$ Idem, p. 18.
} 
também por esse "fora".

A partir desse destronamento da razão já é possível vislumbrar a importância conferida ao corpo no pensamento fenomenológico. O corpo fenomenológico é o corpo em que subjetividade e objetividade se manifestam sem que seja possível uma distinção absoluta entre estes dois polos, ou a prioridade de um sobre outro. De acordo com Merleau-Ponty: "O corpo é o veículo do ser no mundo, e ter um corpo é, para um ser vivo, juntar-se a um meio definido, confundir-se com certos projetos e empenhar-se continuamente neles" ${ }^{\prime 1}$. Ora, ter um corpo é, desse modo, ser um corpo, existir como um corpo, daí que arrisco dizer do caráter ontológico da sua filosofia. Daí também a ambiguidade da nossa condição subjetiva/objetiva, expressão do corpo enquanto sujeito, que para ser entendido em sua integridade, deve ser pensado na relação que estabelece com o mundo e com os outros corpos. No mesmo sentido, ainda, se justifica e se enfatiza a recusa do corpo próprio como puro objeto (como queria Descartes): "O que o impede de ser alguma vez objeto (...) é o fato de ele ser aquilo por que existem objetos. Ele não é nem tangível nem visível na medida em que é aquilo que vê e aquilo que toca" ${ }^{, 32}$ e ainda:

(...) fazer aparecer o corpo como sujeito do movimento e sujeito da percepção - se isso não é verbal, isso quer dizer: o corpo como tocante-tocado, o vidente-visto, lugar de uma espécie de reflexão e, através disso, capaz de relacionar-se a outra coisa que não sua própria massa, de fechar o seu ciclo sobre o visível, sobre o sensível exterior (...). Isto nada tem a ver com uma consciência que desceria num corpo-objeto. ${ }^{33}$

Subjetividade e objetividade aparecem, assim, como "categorias" em relação constante, uma sempre interferindo e determinando a outra, de modo que poderíamos pensar num mundo construído (já que condicionado...) pela nossa percepção:

(...) não há um vidente, primeiramente vazio, que em seguida se abre para [as coisas], mas sim algo de que não poderíamos aproximar-nos mais a não ser apalpando-o com o olhar, coisas que não poderíamos sonhar ver 'inteiramente nuas', porquanto o próprio olhar as envolve e as veste com sua carne ${ }^{34}$;

\footnotetext{
${ }^{31}$ Idem, p. 122.

${ }^{32}$ Idem, p. 136.

${ }^{33}$ MELEAU-PONTY, Maurice. A natureza. São Paulo: Martins fontes, 2006, pp. 337, 338.

${ }^{34}$ MELEAU-PONTY, Maurice. O visivel e o invisível. São Paulo: Perspectiva, 2000, p. 128.
} 
Ora, temos aqui, de modo bastante explícito, a evidência de que o pensamento fenomenológico abandona de fato a noção de verdade absoluta racionalista, já que seria inimaginável ver o mundo inteiramente nu, em sua "verdade cartesiana"35, portanto, e isso pelo simples fato de que o corpo é o meio de acesso ao mundo e, de algum modo, se delimita nessa situação em que se insere (o próprio mundo); do mesmo modo que a razão não pode ser isolada de sua facticidade para perseguir a nudez de todas as coisas.

No corpo fenomenológico os diferentes sentidos não podem ser pensados isoladamente (como tampouco o podem os sentidos e a ideia, ou aquilo que ele nomeia como o visível e o invisível, como veremos mais pormenorizadamente adiante): "o visível não é um zero de tangível, o tangível não é um zero de visível”’36, tudo isso coexiste na elaboração perceptiva. Essa confluência atualizada no momento contínuo da percepção será de grande importância para a análise que se seguirá dos poemas.

Em constante diálogo com a teoria cartesiana, como viemos observando até então - diálogo, vale ressaltar, sempre marcado pelas diferenças que dão sentido à teoria fenomenológica - Merleau-Ponty se ocupa com a demolição do conceito de substância (e por esse motivo, já não importa mais falar em dualismo substancial como importava no caso de Descartes), o que permite a elaboração de uma nova rede de relações, a exemplo desta atualizada pela definição que se segue:

\begin{abstract}
A carne não é matéria, não é espírito, não é substância. Seria preciso, para designá-la, o velho termo 'elemento', no sentido em que era empregado para falar da água, do ar, da terra e do fogo, isto é, no sentido de uma coisa geral, meio caminho entre o indivíduo espáciotemporal e a ideia, espécie de princípio encarnado que importa um estilo de ser em todos os lugares onde se encontra uma parcela sua. Neste sentido a carne é um 'elemento' do Ser. Não fato ou soma de fatos e, no entanto, aderência ao lugar e ao agora. Ainda mais: inauguração do onde e do quando, possibilidade e exigência do fato, numa palavra, facticidade, o que faz com que o fato seja fato. ${ }^{37}$
\end{abstract}

Nota-se, então, que, de acordo com a perspectiva fenomenológica, não importa aquela precisão conceitual submetida aos postulados lógicos da razão, mas uma tentativa de fidelidade na captação de uma manifestação por si só múltipla e

\footnotetext{
${ }^{35}$ Embora Merleau-Ponty não use o termo "verdade", acredito ser viável a interpretação de que a percepção equivaleria, em sua filosofia, a uma espécie de "verdade".

${ }^{36} \mathrm{Idem}$, nota p. 131

${ }^{37}$ Idem, p. 136.
} 
heterogenia e que, por isso, se situa marginalmente em relação à clareza e distinção exigidas na formulação do conhecimento verdadeiro, segundo Descartes. MerleauPonty desde logo adverte para o fato de que aquilo a que chama "carne" ${ }^{38}$ nos termos supracitados é, de fato, o correlato de uma noção para a qual não há nomenclatura na filosofia ocidental, uma vez que inaugura uma maneira de abordagem que ultrapassa a dicotomia espírito/matéria a partir da qual as teorias filosóficas precedentes se debruçaram. Não sendo matéria, a carne é a reunião de todas as percepções esparsas; nas palavras de Merleau-Ponty, a carne é o eu penso que deve acompanhar todas as nossas experiências (numa clara subversão do eu penso cartesiano, que deveria acompanhar, diferentemente, todas as nossas representações...), assinalando, assim, a impossível disjunção entre ideia e experiência.

$\mathrm{Na}$ esteira da comunicação entre o visível e o invisível, isto é, na tentativa de justificar as relações entre o táctil, o visível o audível, etc. e a ideia - atualizadas pela carne - Merleau-Ponty lança mão das artes como exemplos desses modos de relacionamento:

\begin{abstract}
A literatura, a música, as paixões, mas também a experiência do mundo visível são tanto quanto a ciência de Lavoisier e de Ampère, a exploração de um invisível, constituindo ambas no desvendamento de um universo de ideias. Simplesmente, aquele invisível, aquelas ideias não se deixam separar, como as dos cientistas, das aparências sensíveis, mas erigem-se numa segunda positividade (...) não há visão sem anteparo: as ideias de que falamos não seriam por nós mais conhecidas se não possuíssemos corpo e sensibilidade, mas então é que seriam inacessíveis; a "pequena frase", a noção da luz, tanto quanto uma "ideia de inteligência", não se esgotaram nas suas manifestações e só nos poderiam ser dadas como ideias através de uma experiência carnal. ${ }^{39}$
\end{abstract}

Antes de dar continuidade aos desdobramentos da fenomenologia no que diz respeito ao tempo, ao espaço e aos outros corpos (mais precisamente, às relações intercorpos), importa pensar, mediante a conjunção atualizada pela noção de carne, o papel que as artes ocupam no processo de tornar visível o invisível, por assim dizer. Em outras palavras, importa frisar, para o presente propósito, os acontecimentos artísticos como um modo de percepção inaugural ${ }^{40}$, em que ideias e sensações

\footnotetext{
38 "Essa coisa-abertura para as coisas, participáveis por elas, ou que as porta em seu circuito, é propriamente a carne." (MELEAU-PONTY, Maurice. A natureza. São Paulo: Martins Fontes, 2006, p. $359)$.

${ }^{39}$ MELEAU-PONTY, Maurice. O visivel e o invisivel. São Paulo: Perspectiva, 2000, pp. 144, 145.
} 
participam na extensão das elaborações de mundo ${ }^{41}$.

Essa extensão da nossa elaboração de mundo proporcionada pelas artes aparece com evidência na seguinte passagem: “O mundo percebido não é apenas o conjunto de coisas naturais, é também os quadros, as músicas, os livros, tudo o que os alemães chamam de um "mundo cultural"" 42 . Nesse sentido, vale assinalar a seguinte concepção: “(...) existe sempre uma linguagem antes da linguagem que é a percepção" ${ }^{\text {43 }}$. Partindo dessa perspectiva e supondo a percepção como possibilidade de inauguração de um conhecimento, temos que as artes seriam elas mesmas linguagens perceptivas, isto é, a linguagem da arte, se dermos um salto interpretativo, é a percepção mesma enquanto elaboração da linguagem - e enquanto linguagem é que se torna visível. Embora não seja prioridade das artes a inauguração desse conhecimento ou a capacidade de dar a ver a ideia, é nelas que mais facilmente ocorre essa possibilidade $^{44}$. Na experiência comum do mundo visível (na vivência do quotidiano), em geral, estamos submetidos às normas da percepção efetiva, a essa espécie de verdade condicionada pelos nichos sociais em que nos situamos, suas regras de comportamento e sua preponderante economia de meios em favor de uma maior utilidade de resultados dificultam a inauguração do conhecimento, posto que a percepção já estaria viciada; tal como podemos derivar da citação a seguir:

\footnotetext{
${ }^{40}$ Essa percepção inaugural que a viabilização artística proporciona, acredito abarcar o conjunto que envolve o produtor, a obra e a recepção (nesse caso, respectivamente, o poeta/sujeito poético, o poema e o leitor), de forma que abordarei cada uma delas conforme seja adequado para os devidos momentos de análise interpretativa. Importa esclarecer, entretanto, que, de acordo com a perspectiva de leitura eleita, o poeta e o poema são instâncias que se manifestam conjuntamente, uma vez que não tratarei do produtor/poeta num contexto que não aquele que circunscreva as abrangências poéticas/literárias de exclusivo interesse, mas tão somente, tratarei do sujeito poético que se manifesta - ao mesmo tempo que passa a existir - mediante poemas e pronunciamentos acerca do campo de atuação poética.

${ }^{41}$ Aqui se faz apropriada a indicação do caráter sociocultural do seu pensamento, posto que esse processo de conversão do invisível no visível possibilita novas maneiras de entendimento e, como consequência de importância, novas formas de relacionamento social. Essas reflexões serão de grande importância no momento de abordagem dos poemas e, em especial, no momento de exposição dos engajamentos e motivações surrealistas.

${ }^{42}$ MERLEAU-PONTY, Maurice. Conversas - 1948. São Paulo: Martins Fontes, 2009, p. 65.

${ }^{43}$ MELEAU-PONTY, Maurice. A natureza. São Paulo: Martins fontes, 2006, p. 353.

44 “Se muitos pintores, depois de Cézanne, recusaram curvar-se à lei da perspectiva geométrica, é porque queriam recuperar e representar o próprio nascimento da paisagem diante de nossos olhos, é porque não se contentavam com um relatório analítico e queriam aproximar-se do estilo propriamente dito da experiência perceptiva.” (MERLEAU-PONTY, Maurice. Conversas - 1948. São Paulo: Martins Fontes, 2009, p. 14).
} 
As pretensas condições da percepção só se tornam anteriores à própria percepção quando, em lugar de descrever o fenômeno perceptivo como primeira abertura ao projeto, nós supomos em torno dele um meio onde já estejam inscritas todas as explicitações e todas as confrontações que a percepção analítica obterá, onde estejam justificadas todas as normas da percepção efetiva - um lugar da verdade, um mundo. Ao fazer isso, nós subtraímos à percepção a sua função essencial, que é a de fundar ou de inaugurar o conhecimento, e a vemos através de seus resultados. ${ }^{45}$

Assim viciados, os resultados da percepção codificada acabam por funcionar como guias para a percepção futura, fixando, portanto, a estrutura perceptiva que, presa no ciclo, é impedida de viabilizar a inauguração do conhecimento.

Também o aspecto social padece desse prejuízo, já que as investigações epistemológicas e ontológicas que a filosofia e a psicologia empreenderam acerca da problemática perceptiva, não podem ser entendidas sem um intertexto importante: a sociedade. É no seio das relações interpessoais, espaciais e temporais - sempre mediadas pelas regras de convívio social - que ocorre a fixação da percepção. A arte ocupa, portanto, papel de destaque no que se refere à promoção da desestabilização perceptiva, pois que a coloca em movimento mediante a inserção de novos códigos de percepção ainda não estabilizados socialmente, ou seja, não passíveis de regulamentação do ponto de vista utilitário. Merleau-Ponty oferece ainda um exemplo que se encaixa muito bem ao que aqui consideramos como as formas desestabilizadoras da arte:

Se nós nos puséssemos a ver como coisas os intervalos entre as coisas, o aspecto do mundo seria mudado de maneira tão sensível (...). Não seriam mais os mesmos elementos ligados de outra maneira, as mesmas sensações diferentemente associadas, o mesmo texto investido de um outro sentido, a mesma matéria em uma outra forma, mas verdadeiramente um outro mundo. ${ }^{46}$

Retomando as reflexões sobre subjetividade/objetividade e a maneira pela qual elas se definem como cruzamento no ato da percepção, importa verificar os desdobramentos fenomenológicos das relações intersujeitos, das relações espaciais e das relações temporais, o que faremos de forma breve e apenas como direcionamento da leitura dos poemas que sucederá nos próximos capítulos.

Quanto à relação entre sujeitos, ou, mais precisamente, quanto à relação entre

\footnotetext{
${ }^{45}$ MERLEAU-PONTY. Maurice. Fenomenologia da percepção. São Paulo: Martins Fontes, 1996, p. 40.

${ }^{46}$ Idem, p. 39.
} 
os corpos (corpo próprio e corpo de outrem), Merleau-Ponty discorre de forma que não se faz possível excluir os aspectos culturais dessa interação. Tais aspectos são de tal modo intensificados que acabam por embaçar as barreiras entre o eu e o outro, sem, no entanto, diluí-las por completo. Se é verdade que reconheço meu corpo de modo distinto de como reconheço os outros corpos - "[as partes do meu corpo] se relacionam umas às outras de uma maneira original: elas não estão desdobradas umas ao lado das outras, mas envolvidas umas nas outras" ${ }^{\$ 7}$, há, entretanto, um fator de peso a ser considerado: “(...) uma multiplicidade de Eus ou ainda um Eu em geral”,48, que simbolizam a experiência perceptiva num determinado ambiente sociocultural. Por meio da linguagem e de um processo de identificação entre os corpos é que se torna possível reconhecer a existência de outrem e ao mesmo tempo reconhecer a nossa coexistência social:

(...) percebo que outrem é possível para mim como um outro que percebe os mesmos sensíveis que eu percebo. Carne maciça da estesiologia, carne sutilizada da co-percepção, isto é, da identificação entre os esquemas corporais. $\mathrm{O}$ meu esquema corporal projeta-se nos outros e os introjeta, tem relações de ser com eles, procura a identificação, apresenta-se como indiviso com eles, deseja-os. ${ }^{49}$

O sentido da coexistência se completa, precisamente, na condição social:

(...) essa vida estranha [a do outro] é uma vida aberta, assim como a minha com a qual ela se comunica. Ela não se esgota num certo número de funções biológicas ou sensórias. Ela anexa a si objetos naturais desviando-os de seu sentido imediato, ela constrói-se utensílios, instrumentos, ela se projeta no ambiente em objetos culturais. ${ }^{50}$

Essa vida, em princípio, 'estranha' que dizemos ser o outro, é, como vimos, transpassada e completada pelo sujeito na dinâmica perceptiva da qual é resultado o mundo social, assim como o sujeito é transpassado e completado pelo outro nessa mesma dinâmica. Deixa de haver, também aqui, a concepção objectual do corpo próprio, do corpo de outrem ou da sociedade cultural: "trazemos [o social] ligado a nós

\footnotetext{
${ }^{47}$ Idem, p. 143.

${ }^{48}$ Idem, p. 466.

${ }^{49}$ MELEAU-PONTY, Maurice. A natureza. São Paulo: Martins Fontes, 2006, p. 361.

${ }^{50}$ MERLEAU-PONTY. Maurice. Fenomenologia da percepção. São Paulo: Martins Fontes, 1996, p. 474
} 
antes de qualquer objetivação" ${ }^{\text {. }}$.

Não podendo ser de outro modo, a espacialidade em Merleau-Ponty também se apresenta como um eixo de intersecção, não objeto da percepção, mas meio onde a existência ocorre - "[a espacialidade do corpo] não é, como a dos objetos exteriores ou das 'sensações espaciais', uma espacialidade de posição, mas uma espacialidade de situação" ${ }^{\# 2}$ e as consequências dessa forma de relação se dão na noção mesma de existência: "A superação do pensamento euclidiano do espaço tem uma significação ontológica: um espaço diante de nós (projetivo) cede o lugar a um espaço onde estamos, posto que é tão somente métrica do mundo físico" ${ }^{\circledR 3}$, isso, porque não é possível separar a matéria do mundo, ela só existe para nossa percepção como relação. Pelo mesmo motivo as orientações dos conteúdos significativos, (cima, baixo, pequeno, grande, vertical, inclinado...), incluindo-se aqui as do corpo próprio, não se dão por si mesmas, mas exigem o sujeito da percepção, exigem a experiência, a situação; de maneira que o corpo se relaciona com o espaço, não apenas por meio de sua materialidade e nunca como coisa no espaço objetivo, mas enquanto um sistema de ações possiveis $^{54}$. Os dois polos relacionais seriam, portanto, 1) a tarefa (referente às ações possíveis - escolhas) e 2) a situação (referente aos possíveis modos de atuação espacialmente circunscrita).

A mobilidade, como propriedade do corpo, permite ao sujeito transitar por níveis do espaço, de modo que, sempre que nos situamos em determinado 'ambiente', estamos inseridos em determinado nível perceptivo, que nos é solicitado pelo espaço como dado previamente adquirido, uma estrutura na qual estamos contidos. Entretanto, adverte Merleau-Ponty: “Ter experiência de uma estrutura não é recebê-la em si passivamente: é vivê-la, retomá-la, assumi-la, reencontrar seu sentido imanente" ${ }^{\text {"55 }}$ A situação do sujeito no espaço, bem como a sua movimentação são, portanto, variações do poder do sujeito sobre o mundo. O espaço, para além de comportar os fenômenos físicos de posicionamento e deslocamento é também o lugar de projeção de

\footnotetext{
${ }^{51}$ Idem, p. 485.

${ }^{52}$ Idem, p. 146

${ }^{53}$ MELEAU-PONTY, Maurice. A natureza. São Paulo: Martins Fontes, 2006, p. 344.

${ }^{54}$ Cf. MERLEAU-PONTY. Maurice. Fenomenologia da percepção. São Paulo: Martins Fontes, 1996, p. 336.

${ }^{55}$ Idem, p. 348.
} 
significações:

Dissemos que o espaço é existencial; poderíamos dizer da mesma maneira, que a existência é espacial, quer dizer, que por uma necessidade interior, ela se abre a um 'fora', a tal ponto que se pode falar de um espaço mental e de um mundo das significações e dos objetos de pensamento que nelas se constituem. ${ }^{56}$

Dessa forma, Merleau-Ponty inclui a situação espacial no cerne mesmo das relações abarcadas pela existência, considerando a amplitude significativa que a noção de espaço adquire em seu pensamento.

Das reflexões que Merleau-Ponty desenvolve acerca do tempo, interessa-nos, pontualmente para o presente propósito, aquelas em que o tempo é apresentado "não enquanto objeto do nosso saber, mas [como] uma dimensão do nosso ser" ${ }^{\text {"57 }}$, de forma que a subjetividade, mais uma vez (exatamente como ocorre no caso da sua interação com o espaço e com os outros corpos), se define pela sua situação temporal, ao mesmo tempo em que determina qualquer olhar possível para o tempo, não sendo possível falar do tempo como uma síntese objetiva: "É preciso compreender o tempo como sujeito e o sujeito como tempo", afirma Merleau-Ponty, e, logo em seguida continua: “A subjetividade não está no tempo porque ela assume ou vive o tempo e se confunde com a coesão de uma vida" ${ }^{58}$. Ora, de acordo com essa perspectiva, o tempo não é um processo dotado de realidade por si mesmo, mas fruto da relação que eu estabeleço com o mundo. A passagem do tempo (isto é, a mudança) supõe necessariamente alguém que a experiencie, o que ocorre no desdobramento próprio de uma vida, de forma que viver é o único modo de efetuá-la.

Todas as reflexões acerca do corpo, dos outros corpos, do espaço e do tempo, tal como as expusemos acima, implicam numa indissociabilidade, em outras palavras, numa interdependência, que só fazem enfatizar a ideia do sujeito factual, isto é, do sujeito que só se define em situação e por meio de suas relações com o mundo, de forma que, a um só tempo o influencia e é influenciado por este: “A carne do corpo nos faz compreender a carne do mundo" $" 59$.

\footnotetext{
${ }^{56}$ Idem, p. 394.

${ }^{57}$ Idem, p. 557.

${ }^{58}$ Idem, p. 566.

${ }^{59}$ MELEAU-PONTY, Maurice. A natureza. São Paulo: Martins Fontes, 2006, p. 351.
} 
A noção de carne enquanto elemento - eixo relacional e ponto de intersecção entre subjetividade e objetividade - sintetiza, a nosso ver um projeto filosófico que destrona a tradição racionalista e oferece inúmeros argumentos para viabilizar a ancoragem do corpo nas investigações ontológicas, epistemológicas e sociais, como pudemos observar. 


\subsection{Mário Cesariny, Cruzeiro Seixas e Herberto Helder: o corpo in-scrito, o corpo ex-scrito (acrescido de algumas considerações contextuais)}

Deve-se compreender de todas as maneiras ao mesmo tempo, tudo tem um sentido, nós reencontramos sob todos os aspectos a mesma estrutura de ser. ${ }^{60}$

\section{Apresentação}

A partir das teorizações expostas anteriormente, cabe delinear o percurso poético de Mário Cesariny, Cruzeiro Seixas e Herberto Helder (nesta ordem elencados, pois trata-se, neste momento, de pensá-los a partir das respectivas atuações em relação ao surrealismo como forma de contextualização) que, como veremos, se constrói na contramão da lógica cartesiana e se dirige a uma noção de sujeito em que o corpo ganha uma importância muito próxima da importância que tem em MerleauPonty (considerando a flexibilidade da fronteira entre sujeito e objeto, tal como ele defende).

Faz-se necessário, para tanto, definir o campo de atuação poética que cada um dos autores elege para si, levanto em conta as respectivas filiações estéticas e o modo pelo qual elas nos são comunicadas. Nesse momento, importa fazer um panorama do surrealismo e a maneira pela qual Cesariny, por um lado, e Cruzeiro Seixas, por outro, militaram no movimento; e ainda, por um "terceiro lado", as relações de distância e aproximação que Herberto Helder manteve com o surrealismo português, bem como sondar quais as implicações desse "flerte distanciado" em sua obra.

Mais especificamente, interessa demarcar de que forma o corpo aparece no discurso desses autores: o corpo como eixo significativo da elaboração criativa, de tal forma figurativizado que o sujeito lírico é corporificado no discurso poético. Neste primeiro momento, a investigação recai sobre o discurso extra-poético ${ }^{61}$, isto é,

\footnotetext{
${ }^{60}$ MERLEAU-PONTY. Maurice. Fenomenologia da percepção. São Paulo: Martins Fontes, 1996, p. 17.

${ }^{61}$ A questão dos gêneros literários, importa ressaltar, é bastante flexibilizada na produção poética a partir do século XX, e chega a se tornar uma polêmica quando se trata da escrita de Herberto Helder, como demonstram as seguintes palavras de Manuel de Freitas: “(...) pode-se até afirmar, com inteira legitimidade, que Herberto Helder nunca escreveu prosa.” (FREITAS, Manuel de. Pedacinhos de ossos. Lisboa: Averno, 2012, p. 97) . Ainda assim, opto por manter o termo "extra-poético" e por incluir neste quesito algumas citações do livro Photomaton \& Vox que, embora composto por uma gama imensa de variações formais (há aqui uma produção textual que ora se identifica mais proximamente com poemas, ora com prosa ficcional, ora, até mesmo, com ensaios, uma vez que se debruçam sobre a reflexão de determinados autores), considero este um livro que se reporta, no seu todo, às mais variadas formas de elaboração do dizer sobre a escrita. Conforme Maurício Salles Vasconcelos: "Único livro em que
} 
buscamos em textos programáticos, manifestos, prefácios, entrevistas, textos críticos e demais declarações e explicitação das bases sobre as quais os poetas se debruçam para justificar as respectivas poesias.

\section{Surrealistas e simpatizantes: uma história abreviada}

De modo bastante resumido, um olhar para a diversidade de poetas e manifestações que compõe o surrealismo em Portugal $^{62}$ nos oferecerá argumentos para justificar o destaque daquele que mais veementemente se dedicou à intervenção e divulgação surrealista: Mário Cesariny de Vasconcelos.

Apresento um brevíssimo percurso histórico como uma forma de contextualização (entre outras possíveis) e, para tanto, reproduzo alguns dados que fui colher em $O$ Surrealismo em Portugal, de Maria de Fátima Marinho ${ }^{63}$. De acordo com a pesquisadora, em 1941, Antonio Pedro publica o primeiro texto surrealista português: Apenas uma narrativa. Desde 1936, entretanto, António Pedro estava às voltas com o surrealismo inglês, de forma que, a despeito de todas as polêmicas posteriores acerca de sua verve surrealista ${ }^{64}$, António Pedro é considerado pela pesquisadora aquele que

Herberto Helder reúne textos sobre estética, propício ao estabelecimento de uma poética Photomaton \& Vox se mostra inseparável da escrita de poemas (em versos e em prosa) assim como das referencias feitas pelo autor ao seu projeto e itinerário criativos. O livro se compõe, também, da mescla com inserts biográficos e notas sobre história, ou melhor, sobre o seu modo de acontecer na perspectiva do laboratório fotomático-vocal instalado no interior da lírica portuguesa por Helder, desde os fins dos anos de 1950." (VASCONCELOS, Maurício Salles. Jean-Luc Godard: história(s) da literatura. Belo Horizonte: Relicário Edições, 2015, p. 139).

${ }^{62}$ Seria mesmo possível falar em surrealismos portugueses, no plural, tal qual a proposta do congresso decorrido em Lisboa em novembro de 2013: "Congresso Internacional Surrealismo(s) em Portugal. Nos 60 anos da morte de António Maria Lisboa".

${ }^{63}$ Diante do percurso estabelecido pela pesquisadora, me coloco menos como alguém que acata sem concessões essa delimitação, e mais como quem pretende apresentar ao leitor uma sistematização possível; de modo que o encadeamento apresentado por Maria de Fátima Marinho deve ser lido a título informativo, no sentido de que permite ao leitor ter conhecimento da historiografia que se convencionou adotar acerca do surrealismo em Portugal. Me eximo de problematizar devidamente tais questões historiográficas, uma vez que delas faço uso apenas de modo panorâmico e contextual, sem que as considere a questão central desta pesquisa (e o contexto aqui entendido como uma elaboração e fixação crítica mediante determinada forma de estabelecimento historiográfico).

${ }^{64}$ Essa complexificação da postura surrealista de António Pedro é muito bem tratada por Fernando Matos Oliveira: “(...) o que no Surrealismo de António Pedro pode suscitar ambiguidade é, precisamente, a oscilação entre a adesão plena à sua ética mais genuína (que só poderia ser de uma entrega total e absoluta) e à adesão ao estilo surrealista que, apesar de manipulado com maestria, se manteria eticamente em 'equação' com outros momentos menos afirmativos da sua obra. No fundo , a questão resume-se ao seguinte: um autor SURREALISTA não poderia sê-lo apenas durante certo período de tempo." (OLIVEIRA, Fernando Matos. "Introdução" In: PEDRO, António. Antologia 
primeiramente introduziu o surrealismo em Portugal ${ }^{65}$. Sem que se perca muito tempo com tais polêmicas - que sempre têm em vista uma tentativa (a meu ver mais ou menos frustrada) de delimitar o estatuto de um nome - importa sondar, mediante alguns acontecimentos e núcleos de movimentação cultural, a inserção da vanguarda francesa em Portugal.

A partir da década de 40, começam a surgir no país tímidas menções a respeito do movimento encabeçado por Breton, porém, o neorrealismo se mantinha ainda como núcleo predominante (com o qual andou às voltas o próprio Cesariny, muito embora de maneira subversiva ${ }^{66}$ ). De acordo com a perspectiva assumida por Maria de Fátima Marinho, somente em 1947, teria ocorrido o surgimento de um grupo: o Grupo Surrealista de Lisboa. Mas há ressalvas e a própria pesquisadora manifesta hesitação diante dessa delimitação: “(...) em 1947 ainda não há verdadeiramente um grupo surrealista em Portugal. Há sim vários escritores que começam a interessar-se por esse movimento e que iniciam leituras, encontros, experiências e projectos com vista à formação de um movimento organizado"67. Importa alertar para um fato precedente

Poética (introdução seleção e notas de Fernando Matos Oliveira. Braga, Coimbra: Ângelus Novus, 1998, p. XXXIV).

${ }^{65}$ Cf. MARINHO, Maria de Fátima. O surrealismo em Portugal. Lisboa: Imprensa Nacional/Casa da Moeda, 1987, p. 187.

${ }^{66}$ Sobre a produção poética de Cesariny que antecede a sua adesão ao surrealismo, o próprio Cesariny se pronuncia: "Eu comecei como neo-realista e o neo-realismo era uma escola de preconceitos muito rígidos. Não nos deixava ler isto e não nos deixava fazer aquilo e aqueloutro. Era uma orquestra de proibições. Fui muito marcado por isso." (FRANCO, António Cândido. Teixeira de Pascoaes nas palavras do surrealismo em português. Editora Licorne, 2010, p.42). Maria de Fátima Marinho dedica algumas páginas de seu livro, sempre com o intuido de mostrar que o humor e mesmo a ironia surrealista já estavam presentes antes mesmo de Cesariny aderir ao surrealismo: "Nicolau Cansado Escritor é pois uma espécie de retrato irónico dos escritos neo-realistas, tão em voga ao tempo" (Maria de Fátima. O surrealismo em Portugal. Lisboa: Imprensa Nacional/Casa da Moeda, 1987, p. 311). No mesmo sentido Manuel Hermínio Monteiro, nos apresenta a seguinte menção de O'Neill: “Alexandre O'Neill destacará como verdadeiros actos surrealistas do Surrealismo, em Portugal, os happenings do Café Hermínius, a "crudelíssima sátira cesarinyana intitulada Nicolau Cansado Escritor, que consistia na antologia poética de um fictício Cansado que era o impiedoso retrato de muito neo-realismo e muito presencismo então em voga (...)" (MONTEIRO, Manuel Hermínio. "Surrealismo: do "cadáveresquisito' ao gato resplendente andando pela noite" In: A Phala, um século de poesia (edição especial). Lisboa: Assírio \& Alvim, 1988, p. 94). Tais olhares que conotam com traços surrealistas a fase présurrealista de Cesariny contribuem para a problemática histórica que o surrealismo traz para discussão; problemática muito bem sintetizada na justificativa de que Natália Correia lança mão na sua antologia, O Surrealismo na poesia portuguesa: "Os estados dinâmicos do surrealismo hão-de tornar-se visíveis não por uma exposição histórica, mas por um acto surrealista (poético) ou por um relação de simpatia com esse acto, naturalmente hostil a uma redução histórica, que obscureceria as aparições esponâneas que organizam o movimento surrealista" (CORREIA, Natália. O Surrealismo na poesia portuguesa. Lisboa: Frenesi, 2002, p. 5).

${ }^{67}$ Cf. MARINHO, Maria de Fátima. O surrealismo em Portugal. Lisboa: Imprensa Nacional/Casa da Moeda, 1987, p. 28. 
que, de acordo com Adelaide Ginga Tchen, teria favorecido o encontro de alguns dos nomes entre os que posteriormente se reuniriam em torno do surrealismo português: trata-se da escola de Arroio que, conforme atenta a pesquisadora,

No panorama do ensino oficial esta era uma escola modelar pela qualidade pedagógica e humana dominante, onde 'tudo o que se fazia por fora era estimado, compreendido, exaltado', fato que contribuía para a construção de um ambiente salutar numa base de consideração mútua. ${ }^{68}$

$\mathrm{Na}$ António Arroio conviveram Antonio Domingues, Fernando Azevedo, Cruzeiro Seixas, Cesariny, Vespeira, Fernando Lemos e outros:

Antonio Domingues foi o primeiro do grupo a entrar na escola António Arroio, no ano lectivo inaugural, com 13 anos (1934-40); Fernando de Azevedo matriculou-se em 1935, com 12 anos (193540); em 1936 chegaram Cruzeiro Seixas (1936-41), Moniz Pereira (1936-40) e Mário Cesariny (1936-40), os dois primeiros tinham já 16 anos e Cesariny 13; Marcelino Vespeira entrou logo depois, em 1937, com 12 anos (1937-42); Fernando Lemos (1938-43), o mais novo de todos, só chega à António Arroio em 1938, com 12 anos; sobre Fernando José Francisco e Pedro Oom não foi possível determinar datas precisas. ${ }^{69}$

Também Vespeira ressalta a importância dessa convivência juvenil para a formação do grupo no final da década de 40: "Há uma certa linhagem do surrealismo português que deriva daí, da António Arroio e do Hermínius (...)"70, e, recentemente, Cruzeiro Seixas: "Foi realmente na António Arroio com o Mário Cesariny, que era um miúdo que tinha menos dois anos que eu, que começou tudo. Não posso dizer que fosse tudo, tudo, porque há qualquer coisa que nasce já conosco"71.

Cabe, aqui, um olhar curioso para a diversidade de nomes que circula como referência do surrealismo português no ano de 1947: Antonio Domingues, Alexandre O’Neill, Mário Cesariny, Jorge de Sena, Adolfo Casais Monteiro, Vespeira, Fernando de Azevedo, Antonio Pedro, José-Augusto França, Pedro Oom, Antonio Maria Lisboa, Henrique Risques Pereira, Cruzeiro Seixas, Mario Henrique Leiria, e outros ainda ${ }^{72}$, de

\footnotetext{
${ }^{68}$ TCHEN, Adelaide Ginga. A aventura surrealista. Lisboa: Edições Colibre, 2003, p. 153.

${ }^{69}$ Idem, p. 152.

${ }^{70}$ VESPEIRA, M. Apud TCHEN, Adelaide Ginga (Op. cit.), p. 156.

${ }^{71}$ LETRIA, José Jorge. Cruzeiro Seixas: A liberdade Livre. Diálogo com José Jorge Letria. Lisboa: Guerra e Paz, 2014, p. 37.

${ }^{72}$ Além dos nomes já mencionados, Luiz Pacheco acrescenta os seguintes: Henrique Tavares, Luís
} 
modo que, mesmo de forma dispersa, pode se pensar no surrealismo como um movimento de grande impacto e que permeia boa parte dos poetas, artistas visuais e críticos portugueses ao longo do século $\mathrm{XX}^{73}$. Embora o grau de adesão ao movimento seja bastante irregular em cada um dos nomes supramencionados, todos, de alguma forma, manifestaram algum interesse pela divulgação da vanguarda que apenas tardiamente se manifesta em Portugal ${ }^{74}$. Entre diversas adesões e abandonos, há um fato que merece destaque e que será determinante para a prática surrealista em Portugal: em 1948 Cesariny remete uma carta a Antonio Pedro comunicando o seu rompimento com o Grupo Surrealista de Lisboa nos seguintes termos:

Serve esta para dizer que me desligo inteiramente do Grupo Surrealista de Lisboa por não acreditar que seja Grupo e ainda menos que seja Surrealista. Quanto aos demais pormenores, creio-os suficientemente conhecidos (ou debatidos ou palpitados) por todos, para que seja necessário o cartapázio da praxe e os alguns gritos lancinantes do costume. ${ }^{75}$

Também em carta direcionada a O’Neill e António Domingues, Cesariny expõe o seu descontentamento com o Grupo Surrealista de Lisboa. Nesta correspondência há alguns pontos que nos interessam particularmente: as críticas que dirige contra " $\mathrm{O}$ esteticismo, camuflado ou migado, concorrendo para o relegamento dos fenômenos ditos de acaso (...) e a grande desistência de um estado de revolta contra o meio

Pestana da Marinha, José Carlos Gonzales, Jõao Fernandes, Manuel Crespo e José Manuel Simões. (Cf. PACHECO, Luiz. O espelho libertino. São Paulo: Escrituras, 2007, p. 56.)

${ }^{73}$ Seria mesmo possível fazer uma leitura do surrealismo em Portugal como o grande catalizador da produção cultural portuguesa ao longo do século XX; já que, mais ou menos engajados no movimento, por ele circularam nomes como: António Barahona da Fonseca, Manuel de Castro, Mário Botas, Paula Rego, Júlio Pomar, Vieira da Silva e Arpad Szenes, D’Assumpção, Carlos Calvet, Helder Macedo, e certamente muitos outros que uma listagem exaustiva poderia trazer. Isso sem considerar as repercussões do surrealismo para a nova geração de poetas vivos e artistas em geral, alguns deles, como é o caso de Miguel de Carvalho, declaradamente adepto do movimento e continuamente em contato com surrealistas do mundo todo. Sobre o surrealismo francês, Maurice Blanchot reconhece abrangência semelhante: "Não existe mais a escola [surrealista], mas um estado de espírito subsiste. Ninguém mais pertence a esse movimento, e todos sentem que poderiam ter participado dele. Em toda pessoa que escreve há uma vocação surrealista confessa, que aborta, que aparece algumas vezes usurpada, mas que, mesmo falsa, expressa um esforço e uma necessidade sincera. O surrealismo desapareceu? É que ele não está aqui ou ali: ele está em toda parte. É um fantasma, uma brilhante obsessão por sua vez, metamorfose, merecida, tornou-se surreal.” (BLANCHOT, Maurice. A parte do fogo. Rio de Janeiro: Rocco, 2011, p. 94.)

${ }^{74}$ Entre os portugueses, o movimento ganha força apenas nos fins da década de quarenta, se distanciando mais de 20 anos do primeiro manifesto de Breton. Para uma exposição mais detalhada das relações entre Surrealismo Francês e Surrealismo Português, vide: MARINHO, Maria de Fátima. $O$ surrealismo em Portugal. Lisboa: Imprensa Nacional/Casa da Moeda, 1987, p. 29-42, p. 50, p. 55, p. 6977 , p. 123-156.

${ }^{75}$ CESARINY, Mário. As mãos na água a cabeça no mar. Lisboa: Assírio \& Alvim, 1985, p. 309. 
pulvimerdento que nos rodeia." ${ }^{, 76}$. Nota-se, nestas críticas, uma atitude de intolerância diante de uma postura acerca do surrealismo (postura assumida pelos integrantes do Grupo Surrealista de Lisboa, vale lembrar, encabeçado por António Pedro) que, segundo Cesariny, estaria aquém do significado que ele conota ao movimento. Para Cesariny, o surrealismo deveria abarcar, além do teor político e combativo (com especial ênfase para o fato de que Portugal, a esta época, vive sob a ditadura salazarista, e nesta chave de leitura é que lemos a expressão: "estado de revolta contra o meio pulvimerdento que nos rodeia"), um teor ontológico e epistemológico: o poema, e as artes plásticas, enquanto manifestações da surrealidade deveriam ser propulsores de uma nova forma de pensar e de existir, desvelando possibilidades latentes de relações entre os significados (a propósito, vale frisar, bem de acordo com a proposta de Merleau-Ponty, já que a defesa que este faz da percepção como motor primeiro e único de acesso ao mundo, revela um empenho de não privar a percepção da sua função essencial, que é a de fundar ou de inaugurar o conhecimento, tendência que aponta justamente para as tais possibilidades latentes de modos de relação que podem surgir na nossa forma de perceber e organizar o mundo). É exatamente isso que parece defender Cesariny quando condena o esteticismo que, segundo ele, seria norteador da prática do Grupo Surrealista de Lisboa. Essa demarcação de radicalidade da proposta surrealista operada por Cesariny acaba por marcar o modo de atuação do surrealismo português, que, daí em diante - e de maneira progressiva - passa a ser indissociável do nome de Cesariny.

Não é, no entanto, possível tomar a acusação de Cesariny a sério, já que, diferentemente do que ele diz, o Grupo Surrealista de Lisboa apresenta sim uma atividade política, ou, para tomar emprestadas as suas próprias palavras, um "estado de revolta contra o meio pulvimerdento que nos rodeia”, tal qual demonstra a capa do catálogo de sua primeira e única exposição ${ }^{77}$ (primeira e única, já que em 1949, o Grupo Surrealista de Lisboa se desfaz após censura do governo contra esta mesma capa):

Os expositores pretendiam intervir (...) na campanha para a eleição do Presidente da República então em curso (...) decidiram imprimir na capa do catálogo um manifesto anti-fascista: 'O Grupo Surrealista de Lisboa pergunta depois de 22 anos de MEDO ainda seremos capazes de um ato de

\footnotetext{
${ }^{76}$ Idem, pp. 308, 309.

${ }^{77}$ ANEXO A, p. 227.
} 
liberdade? É absolutamente indispensável votar contra o fascismo, ${ }^{, 78}$.

Cesariny, já sem relações com Antonio Pedro, se reúne num novo agrupamento: Os Surrealistas Dissidentes ou, simplesmente, Os Surrealistas, do qual faziam parte, inicialmente, Antonio Maria Lisboa, Pedro Oom, Fernando Alves dos Santos, Henrique Risques Pereira, Cruzeiro Seixas e Carlos Eurico da Costa. Também entre os Dissidentes, há alguma mobilidade entre os participantes, de forma que a pesquisadora defende que 1951 é o último ano em que temos notícias das atividades surrealistas como acontecimento coletivo e regular ${ }^{79}$. Outros escritores, pintores e poetas manifestam alguma afinidade com os membros do Surrealismo Dissidente neste momento, como é o caso de Manuel de Lima, Natália Correia, Isabel Meyrelles e Luiz Pacheco (apenas para mencionar os mais expressivos), entretanto, isso ocorre de forma bastante pontual.

Entre 1955 e 1956, uma manifestação diversa vem particularizar ainda mais esse agrupamento de pessoas: o Café Gelo passa a ser o ponto de encontro de Cesariny, Luiz Pacheco, Manuel de Lima, Antonio José Forte, João Rodrigues, Manuel de Castro, João Vieira, Helder Macedo e Herberto Helder. Essas reuniões estendem-se até o início da década de 60. Em 58 são publicados os volumes de A antologia em 1958; em 61, é publicada a Antologia Surrealista do Cadáver Esquisito, um livro que reúne a produção poética coletiva dos autores supramencionados (entre eles, importa frisar, surrealistas e simpatizantes); e em 63 a antologia Surrealismo/Abjeccionismo. De fato, tais autores, de acordo com Cesariny ${ }^{80}$, reúnem-se em torno daquilo que Pedro Oom

\footnotetext{
${ }^{78}$ MARINHO, Maria de Fátima. O surrealismo em Portugal. Lisboa: Imprensa Nacional/Casa da Moeda, 1987, pp. 46, 47. Segue em anexo, a reprodução da capa (p. 172). As repercussões negativas do apelo político somadas à dissolução do Grupo Surrealista de Lisboa acabam por situar Antonio Pedro na marginalidade, embora ele tenha seguido como poeta, pintor e, mais tarde, iria dedicar-se ao teatro.

${ }^{79}$ Sabemos que em 1948 ocorrem as primeiras experiências de criação coletiva (cadáveres esquisitos) e no mesmo ano iniciam-se as ações no Jardim Universitário das Belas Artes (JUBA), que se estenderão até 1949. Além disso, há uma série de textos programáticos divulgados em jornais e revistas literárias, bem como exposições coletivas e individuais. Tais eventos, atesta a pesquisador, seriam o suficiente para se pensar no surrealismo em atividade enquanto agrupamento, e a ausência dessas mesmas atividades, seria, por consequência, o bastante para se dizer da extinção do grupo. Em 1951 Cruzeiro Seixas parte para África e, em 1953 morre Antonio Maria Lisboa, fatos que acabam por diluir ainda mais a coesão inicial do grupo, pois, como bem formulou Natália Correia, a trilogia cupular do grupo Surrealista Dissidente era constituída por Artur Cruzeiro Seixas, Mário Cesariny e Antonio Maria Lisboa (Cf. CORREIA, Natália. O surrealismo na poesia portuguesa. Lisboa: Frenesi, 2002, pp. 429, 430.). Para uma visada mais detalhada dos eventos surrealistas, mediante uma perspectiva histórica, vide TCHEN, Adelaide Ginga. "Cronologia” in A aventura surrealista. Lisboa: Edições Colibri, 2001.

80 “Em 1956-59 outra geração surgirá constituindo os chamados grupos do Café Royal e do Café Gelo. Estes grupos (...) voltar-se-ão mais a um 'abjeccionismo' conjuntural do que à proposta surrealista, e,
} 
viria a denominar Abjecciocismo, uma variação portuguesa em relação ao surrealismo francês:

No abjeccionismo, que é, antes de tudo, uma atitude concebida para a sobrevivência do indivíduo sem lhe coactar a livre floração da personalidade e, ao mesmo tempo, para lhe fornecer armas mentais que the permitam afirmar-se eliminando o atrito que possa surgir entre ele e os outros indivíduos do agregado social a que pertence, também se acredita numa Realidade Absoluta e o seu fim é o mesmo do surrealismo: a transformação dos valores básicos da sociedade 'moderna', dita civilizada, através da transformação moral e espiritual do indivíduo isolado, isto é, considerado isoladamente como um todo e não como mera peça na colectividade (...) a posição abjeccionista se baseia na resposta que cada um dará à pergunta: 'que pode fazer um homem desesperado quando o ar é um vómito e nós seres abjectos?'. A diferença fundamental entre surrealismo e abjeccionismo está no seguinte: nós também acreditamos na existência de um determinado ponto do espírito onde a vida e a morte, o alto e o baixo, o sonho e a vigília, etc., deixam de ser contraditoriamente apercebidos, mas cremos igualmente na existência de um outro ponto do espírito onde, simultaneamente à resolução das antinomias se toma consciência das forças em germe que irão criar novos antagonismos. ${ }^{81}$

Essa longa citação apresenta alguns pontos de interesse que justificam o uso do termo "simpatizantes" que utilizamos em referência aos autores não declaradamente surrealistas que se envolveram, de algum modo, com alguns dos ideais surrealistas. Adiante, veremos de que modo o abjeccionismo servirá como justificativa para pensarmos a alternância entre aproximação e distanciamento que Herberto Helder manteve em relação ao surrealismo.

Por ora, vale evidenciar três pontos que nos chamam atenção nessa exposição do Abjeccionismo: 1) a ênfase na posição individual em detrimento da obediência a pressupostos que venham a reger uma coletividade determinada (como aqui interpretamos, uma proposta de flexibilização do surrealismo ortodoxo - que exigiria uma radical assunção dos dogmas que determinam suas práticas. No mesmo sentido, poderíamos ainda retomar a experiência do surrealismo francês no que se refere ao elo que este manteve inicialmente com o comunismo: consta que Breton exigia dos demais

por exaltantes que tivessem sido para mim a adesão e a companhia, recuso continuar a experiência (...)." (CESARINY, Mário. As mãos na água a cabeça no mar. Lisboa: Assírio \& Alvim, 1985, p. 280).

81 "Pedro Oom: um homem pode entrar livremente numa prisão e sair dela mais amarrado do que quando para lá entrou” in CESARINY, Mário. A Intervenção Surrealista. Lisboa: Assírio \& Alvim, 1997, pp. 291, 292 (texto referente a uma entrevista concedida por Pedro Oom ao Jornal de Letras e Artes de 1963). 
participantes a subordinação a uma ideologia política que naquele momento era vista como consoante à prática surrealista ${ }^{82}$ ), exatamente como defende Fernando J. B. Martinho: “O abjeccionismo (...) não via com bons olhos a possibilidade de o surrealismo se transformar numa outra escola, numa ortodoxia que se arrogasse o direito de pôr limites à liberdade de criação e, inquisitorialmente, se dedicasse a actos de excomunhão." ${ }^{83}$; 2) o contexto de hostilidade política e moral de Portugal sob a ditadura salazarista ("quando o ar é um vómito”...), que acaba por tornar os poetas e os cidadãos portugueses, de modo geral, "seres abjectos"; e 3) a ideia de que não seria possível diluir por completo as antinomias, como queriam os surrealistas franceses, de forma que haveria uma renovação incessante destas, constatação que aponta para o princípio da metamorfose, como veremos mais detalhadamente.

De acordo com Monica Simas, entre surrealismo e abjeccionismo, haveria uma diferença que, ao fim, reconduziria ambos a uma delimitação imposta pela linguagem mesma:

Se o abjeccionismo, em sua práxis teórica, parece remeter o sujeito no sentido contrário às forças positivadoras do surrealismo, a negação que dessa postura decorre e que parece não dar trégua às obrigações da reflexão, permite à consciência lidar com o irromper do vazio no discurso, o mesmo vazio que, no surrealismo, pode preencher-se a partir dos limites da própria linguagem. ${ }^{84}$

A perspectiva oferecida por Monica Simas me parece bastante justificável, tanto mais se tivermos em conta que "os limites da própria linguagem" são também os limites da própria existência, dado que a existência em termos de humanidade é

\footnotetext{
${ }^{82}$ Apesar de Michel Löwy defender um marxismo libertário em André Breton devido às relações que este teria estabelecido entre maravilhoso surrealista e ação política, entre sonho e materialismo histórico, não é possível ignorar que as suas declaradas relações com o comunismo implicam na obediência a uma ortodoxia ideológica, minando, inevitavelmente, os posicionamentos individuais - já bastante fragilizados pelo credo surrealista per si que, também na França, redundou em expulsões e abandono de membros participantes do movimento. Curioso notar que o próprio Michel Löwy atenta para esses fatos: "A adesão dos surrealistas ao materialismo histórico, solenemente afirmada por Breton no Segundo Manifesto, marcou profundamente a história do movimento e particularmente aquela de seu posicionamento político. São conhecidos os principais momentos desse percurso: a entrada no Partido Comunista Francês em 1927; a ruptura com o comunismo stalinista por ocasião do Congresso em Defesa da Cultura de 1935; a visita de Breton a Trotski no México em 1938 e a fundação da Fiari (Federação Internacional de Arte Revolucionária Independente) (...)" (LÖWY, Michel. A estrela da manhã: surrealismo e marxismo. Rio de Janeiro: Civilização Brasileira, 2002, p. 14).

${ }^{83}$ MARTINHO, Fernando J. B. Tendências dominantes da poesia portuguesa da década de 50. Lisboa: Edições Colibri, 2013 ( $2^{\mathrm{a}}$ edição), p. 68.

${ }^{84}$ SIMAS, Monica. "Surrealismo e Abjeccionismo: dois movimentos controversos". Anais do XX Encontro de Professores Brasileiros de literatura Portuguesa - No Limite dos Sentidos. Rio de Janeiro: L. Christianol/Newbooks Editoração Eletrônica, 2005. CD-ROM.
} 
condicionada e determinada pela linguagem.

Uma vez evidenciadas as especificidades do abjeccionismo em relação ao surrealismo nos moldes bretonianos (e mesmo nos moldes cesarinyanianos, por assim dizer), retornaremos a elas no momento em que formos pensar a atuação de Herberto Helder. Não, entretanto, sem que se faça valer o testemunho de Helder Macedo acerca das reuniões no Café Gelo:

Caracterizar-nos como um grupo - o "Grupo do Gelo" - como tem sido feito, e depois rotular-nos a todos de "surrealistas" ou de "abjeccionistas", como se persiste em fazer, é no entanto redutor da nossa tantas vezes conflituosa diversidade. Evitemos portanto esses ou quaisquer outros rótulos já então gastos pelo uso e que neutralizam mais do que revelam. É certo que todos nós, de um modo ou de outro, prestámos homenagem aos surrealistas que nos precederam. Mas também aos futuristas que os precederam. E ao Cesário Verde que a todos precedeu. E ao Carlos Drummond de Andrade que metemos de permeio entre o Pessoa e o Cesariny. Já o disse e digo de novo aqui: O que todos nós, os do Café Gelo, tínhamos em comum era uma atitude de recusa, uma partilhada vontade de quebrar amarras, um só sabermos o que não queríamos para podermos deixar um espaço livre para o que pudéssemos talvez querer. A recusa de normas estabelecidas era a nossa única norma. $\mathrm{O}$ questionamento de valores impostos o nosso único valor. As noites eram os nossos dias. Se vivíamos num mundo às avessas, tínhamos de conseguir viver no avesso das avessas. Estávamos todos muito zangados com o que queriam fazer de nós: o governo, as universidades, as várias polícias que não nos queriam deixar ser quem ainda não sabíamos que poderíamos querer ser, os intelectuais estabelecidos que nos queriam ensinar a sermos quem não queríamos ser. Desdenhávamos rótulos, desprezávamos preconceitos. $^{85}$

Ora, o testemunho que nos apresenta Macedo, permite que a historiografia traçada por Maria de Fátima Marinho seja, minimamente, relativizada, uma vez que, de acordo com o poeta e professor que lá esteve, Mário Cesariny começou a frequentar tais reuniões algum tempo depois delas já estarem em curso:

O Mário Cesariny, mais velho do que nós, foi acolhido no Gelo com respeitoso júbilo, não como o "penado" que a moralidade oficial tinha forçado a ser mas como um predecessor que tinha aprendido, antes de nós, que "faz-se luz pelo processo de eliminação de sombras". 86

Ao que continua:

\footnotetext{
${ }^{85}$ MACEDO, Helder. "A utopia da negação", Arte \& Utopia (Ed Margarida Acciaiuoli, Ana Duarte Rodrigues, Maria João Castro, Paula André, Paulo Simões Rodrigues) CHAIA; DINÂMICA'CET-IUL; FCSH, Lisboa, 2013 (pp. 237-244), pp. 239, 240.

${ }^{86}$ Idem, p. 240
} 
Nós surrealistas? Tudo aquilo era abjeccionismo? Sim, claro, mas também não. Aliás não sei se alguma vez terá havido surrealismo em Portugal e, se houve, as circunstâncias portuguesas desde logo separaram os que viram nele uma metodologia estética, como terá sido o caso de Ernesto Sampaio, e os que o adoptaram como uma atitude política. ${ }^{87}$

Helder Macedo apresenta, por fim, este parecer do que teriam sido, de fato, as reuniões no Café Gelo:

Para os arrumadores retrospectivos das literaturas e das artes o Gelo foi o húmus de onde emergiram vários notáveis pintores e, consensualmente, o poeta português mais importante (e certamente

E mais: mais influente) da segunda metade do Século XX, Herberto Helder. ${ }^{88}$

Por isto se entende, se alguma coisa disto se pode entender, que não é pela literatura, que não é sequer pela pintura em que alguns depois prosperaram que o Gelo merece ser recordado. Repito: é pelo que então não queríamos ser onde não podíamos estar. Ou seja: não é pelo que depois nos tornámos mas pelo que não chegámos a ser. Porque nunca se chega a ser, como então já sabíamos (...). O que havia de comum em todos nós era um grande nojo partilhado em modos convergentes de o exprimirmos. ${ }^{89}$

Estas palavras finais parecem-me adequar-se, de algum modo, à ideia central contida naquilo que Pedro Oom iria nomear como abjeccionismo, ainda que o façam pela via negativa: trata-se justamente da recusa que dá título ao belo ensaio/testemunho de Helder Macedo: "A utopia da negação". A importância de que se reveste este testemunho, vem assinalar a complexidade inscrita em eventos literários e artísticos como tais, fato muitas vezes ignorado por aqueles que se ocupam da delimitação histórica que, tal como tento abarcar na presente pesquisa, deve aparecer apenas como mais um dos discursos aproximativos ao que teria sido não apenas as reuniões no Café Gelo, mas o surrealismo português com toda a centralidade auto demarcada por Mário Cesariny.

Nesse mesmo sentido, creio que seria possível pensar, juntamente com o professor Fernando Cabral Martins ${ }^{90}$, que o precursor do surrealismo em Portugal não

\footnotetext{
${ }^{87}$ Idem, p. 241.

${ }^{88}$ Idem, p. 242.

${ }^{89}$ Idem, p. 244.

${ }^{90}$ Agradeço ao professor Fernando Cabral Martins que, em conversa informal, possibilitou que algumas intuições minhas se confirmassem: não apenas acerca da historiografia surrealista estabelecida, mas
} 
seria Antonio Pedro, mas Almada Negreiros: neste caso, uma nova historiografia se justificaria, se lêssemos, por exemplo, os versos iniciais (que são também os versos finais) do poema "You are welcome to Elsinore", de Cesariny: "entre nós e as palavras (...)"91, como uma provável citação de $A$ invenção do dia claro, de Almada:

\section{"NÓS E AS PALAVRAS:}

Nós não somos do século d'inventar as palavras. As palavras já foram inventadas. Nós somos do século d'inventar outra vez as palavras que já foram inventadas." ${ }^{\text {92 }}$.

Interessa, entretanto, voltar a atenção à atuação de Mário Cesariny, que, desde o novo agrupamento, se auto-coroa o mentor do surrealismo português, não apenas pela constância com que se disse surrealista (mesmo após a dissolução de todos os grupos...), mas ainda por ter sido responsável pela divulgação do surrealismo português e internacional mediante a publicação de livros como Jornal do gato, de 1974, Textos de afirmação e de combate do surrealismo mundial, de 1977, As mãos na água, a cabeça no mar, de 1985 e A Intervenção Surrealista, de 1997.

A filiação declarada ao surrealismo por Mário Cesariny se estabelece como uma demarcação ideológica que, importa frisar, rompe imediatamente com a lógica cartesiana: a noção de que a poesia é resultado de uma deflagração no modo de pensar e agir racionalistas e, por isso, oferece meios para a reconstrução do homem despido dos limites impostos pelo pensamento lógico ${ }^{93}$. Pela insistência com que se define enquanto uma ética, o surrealismo se apresenta como uma proposta de associação intrínseca entre o fazer poético e o modus vivendi, o que redunda numa recusa da ideia do surrealismo como movimento literário ou artístico meramente restrito - exatamente como já vimos na crítica que dirige contra o Grupo Surrealista de Lisboa, em que condena o esteticismo ali presente, e aqui se reproduz com algumas variações:

\footnotetext{
especialmente acerca da importância de Almada Negreiros para o surrealismo português.

${ }^{91}$ CESARINY, Mário. Uma grande razão. Lisboa: Assírio \& Alvim, 2007, p. 67.

${ }^{92}$ NEGREIROS, Almada. A invenção do dia claro. Lisboa: Assírio \& Alvim, 2005, p. 20.

${ }^{93}$ Essa afirmação também se aplica ao caso de Cruzeiro Seixas, uma vez que ele aderiu, tanto quanto Cesariny, aos postulados do surrealismo. A grande diferença entre ambos, como fica claro, é que Cesariny assume uma postura muito próxima daquela assumida por Breton na França: toma para si a tarefa de divulgação e de definição dos postulados do movimento. Conforme o relato de Cruzeiro Seixas: "[Mário] era um Saint-Germain-des-Prés em Lisboa, e aquilo não me interessava nada. Os cafés, ter um grupo, ter dois grupos, ter um grupo neste café, outro naquele café, onde ele pontificava." LETRIA, José Jorge. Cruzeiros Seixas: A liberdade livre. Diálogo com José Jorge Letria. Lisboa: Guerra \& Paz, 2014, p. 84.
} 
(...) a Literatura nunca nos ocupará demasiado; dizendo literatura somos percebidos -, a nossa aceitação de certos postulados do surrealismo, primeiro, e depois a prática consciente e apaixonada, levaram-nos ao corte definitivo não só com o naturalismo e respectivo cortejo de razões interpretacionistas, mas com toda a expressão unicamente interpretativa (estilizante) $<<$ do real $>>.^{94}$

e, ainda, em 1962, ao ser entrevistado pelo Jornal de Letras e Artes: “(...) não sei se sabe que o surrealismo - mas não só o surrealismo -, vai para umas dezenas de anos, anunciou a morte da literatura, num propósito não muito divergente do da filosofia ainda romântica que, no século passado, tocou os sinos pela morte de Deus." "95, ao que continua: “(...) quando digo poeta não digo fazedor de poemas, digo poeta, figura bem mais vasta do que andam a dar a ler os tipógrafos" ${ }^{96}$. Sobre as afirmações supramencionadas, vale frisar que Cesariny incorporou o preceito bretoniano de que o surrealismo não é escola literária ou, de modo mais geral, artística, mas atitude moral e, em alguma medida, ontológica e epistemológica, pois se apresenta enquanto uma concepção do homem e visão de mundo. Imediatamente somos remetidos às afirmações de Breton: “(...) há que se admitir, afinal, que o surrealismo não teve outra intenção senão a de provocar, do ponto de vista intelectual e moral, uma crise de consciência de espécie mais geral e mais séria (...)"97, e ainda: "A nós (...) compete procurar aperceber sempre mais claramente o que se trama sem o homem saber, nas profundezas de seu espírito (...)"98.

O meio artístico de sua manifestação resulta, desse modo, da ideia de que as artes e, neste caso específico, a poesia seriam as formas mais propícias de burlar o império da lógica, no qual os mecanismos do pensamento humano, e por consequência, o funcionamento da sociedade estariam "aprisionados". Pelo mesmo motivo, encontramos grande diversidade de manifestações artísticas por parte dos membros do surrealismo que transitavam entre a escrita, a pintura, a escultura, como foi o caso de Cesariny e Cruzeiro Seixas.

\footnotetext{
94 CESARINY, Mário. 'Sem título' in A Intervenção Surrealista. Lisboa: Assírio \& Alvim, 1997, pp. 88, 89.

${ }^{95}$ CESARINY, Mário. 'Entrevista ao Jornal de letras e artes (1962)' in A Intervenção Surrealista. Lisboa: Assírio \& Alvim, 1997, p. 282.

${ }^{96}$ Idem, p. 283.

97 BRETON, André. "Segundo manifesto do surrealismo" In: BRETON, André. Manifestos do surrealismo. São Paulo: Editora Brasiliense, 1985, p. 97.

${ }^{98}$ Idem, p. 135.
} 
Parece-me relevante, entretanto, subverter essa recusa estética do surrealismo e dar um salto além, uma vez que penso ser a estética ela mesma uma forma de manifestação ética, ou seja, o que flagro tendo em vista os resultados artísticos das manifestações surrealistas, não é exatamente uma recusa da estética, mas a transformação desta numa ética. Do grego aisthêtiké, a origem da palavra traduz o seu significado: o conhecimento pelos sentidos, de modo que poderíamos pensar o surrealismo como uma afirmação da ética a partir do caráter sensorial de que a criação artística se vale. Daí estética e ética deixam de figurar como termos excludentes e a recusa do "esteticismo" na qual se empenham os surrealistas, figura apenas como crítica a uma postura artística desprovida de ética, em que o resultado criativo seria meramente um adorno. ${ }^{99}$

Com o intuito de evidenciar a coincidência proposta entre vida e obra (implicada na concepção ética da criação surrealista), dizemos que a ênfase surrealista na coletividade coincide com a noção de uma "vida surrealista" que é também um projeto coletivo (formação de grupos, encontros em cafés, realizações de exposições, produções poéticas coletivas), cuja finalidade maior se resume na palavra liberdade. Em palavras mais adequadas, Ernesto Sampaio afirma:

Não é pedir muito à vida - apenas o essencial - viver num estado de tensão sensível propício ao estabelecimento de cumplicidades fulgurantes entre o coração, o pensamento e um universo que de

\footnotetext{
${ }^{99}$ A respeito do simbolismo em Portugal, Gustavo Rubim se pronuncia de modo que a reflexão em debate seja aplicável também no caso do surrealismo, uma vez que se direciona para a afirmação de uma interdependência entre ética e estética: “Se a 'consciência de missão' se define pela vontade de conjugar harmoniosamente literatura e acção histórica, então, como diz Ocatavio Paz 'a doutrina da 'arte pela arte', que parece negar essa atitude, confirma-a e prolonga-a: mais que uma estética foi uma ética e ainda, muitas vezes, uma religião e uma política' (Paz, 1974, p. 92). Uma religião e uma política a que (...) não é alheio o esteticismo de Eugénio de Castro. Religião ou, pelo menos, culto da palavra poética como 'silva esotérica para raros apenas', o esteticismo define-se, antes de tudo, pela redução da questão da poesia ao domínio da estética (no duplo sentido - territorial e político - da palavra 'domínio'). Ora, este autêntico enclausuramento equivale a uma neutralização da poesia enquanto questão crítica, isto é: à sua codificação como território de linguagem bem definido e bem delimitado, que se distingue rigorosamente de tudo aquilo com que confina e que, sobretudo, coincide sempre consigo mesmo, com a sua identidade ou essência definida em nome de fins superiores. E é nesse ponto que, ao invés de negar, o esteticismo confirma e prolonga a chamada 'literatura militante': na pressuposição de uma finalidade (social, ideológica ou estética) em cujos limites estáveis se encerra a função do discurso literário. Nesse sentido, pode muito bem dizer-se que a atitude esteticista e a atitude militante (ou 'vitalista') não existem uma sem a outra e, mais ainda, que não chegam a ter qualquer existência real fora da polêmica que as opõe e, desse modo, lhes dá sentido." (RUBIM, Gustavo. Experiência da alucinação. Camilo Pessanha e a questão da poesia. Lisboa: Editorial Caminho, 1993, p. 62). Ainda a respeito das relações entre ética e estética, nos fala Manuel Gusmão em ensaio dedicado à Mário Cesariny: "O poético tornase uma modalidade ética da linguagem." (GUSMÃO, Manuel. "Entre nós e as palavras (Mário Cesariny)” In: Tatuagem e palimpsesto. Lisboa: Assírio \& Alvim, 2010, p. 406.).
} 
nenhum modo nos é indiferente. Não é pedir-lhe muito - apenas não desmerecer dela - jogar no amor todas as chances de cumprimento supremo desse encontro, e saber reconhecer os sinais com que o mundo nos significa o seu acordo, saber reconhecê-los em todo o nosso tempo e todo o nosso espaço, só nossos quando verdadeiramente livres, conquistados em luta contra o que reduz, destrói e mutila a tensão extrema do ser na conjunção maravilhosa do desejo e da realidade exterior. ${ }^{100}$

Esse trecho apresenta ainda de que maneira essa vida surrealista acontece: mediante uma integração plena entre tempo, espaço e sujeito, embaçando, assim, e exatamente como propõe Merleau-Ponty, as fronteiras entre subjetividade e objetividade. A um só tempo, seguem as palavras de Ernesto Sampaio e de André Breton que reiteram essa proposta: "Tudo incitava o homem autêntico a não aceitar o realismo, isto é, a não desistir de agir sobre a realidade exterior. A realidade, seja a das palavras, seja a das coisas, contém a surrealidade. 'Nada do que nos rodeia nos é objecto; tudo nos é sujeito' (Breton)"101.

O empenho coletivista, ao qual nos referimos, aparece no discurso de Cesariny nos seguintes termos: “(...) procede o cadáver esquisito que é poesia, o qual tende a fundir num só total delirante parcelas diferenciadas como 7 mais 4 mais 5 igual a um que aparece e é um homem que marcha de olhos muito abertos através pontos-vácuo da universal matéria [grifo nosso]."102; ainda: "Quatro homens livres não são mais liberdade do que um só. Mas são mais reverbero no mesmo fulgor." "103; e mais: "O máximo de liberdade de expressão individual gerando o máximo disponível de expressão colectiva" ${ }^{\text {104 }}$. Mais uma vez, recorremos a Merleau-Ponty e àquilo que ele entende por corpo: um sistema universal interior-exterior, “(...) há indivisão do meu corpo, do meu corpo e do mundo, do meu corpo e dos outros corpos entre si (...) Projeção - introjeção"105. Essa aglutinação de muitos corpos, redundando no corpo do

\footnotetext{
${ }^{100}$ SAMPAIO, Ernesto. O sal vertido. Lisboa: Hiena Editora, 1988, p. 21.

${ }^{101}$ Idem, p. 29.

${ }^{102}$ CESARINY, Mário "Na publicação da Antologia do cadáver esquisito", in A Intervenção Surrealista, Lisboa: Assírio \& Alvim, 1997, p.277.

${ }^{103}$ CESARINY, Mário. 'Autoridade e liberdade são uma e mesma coisa', in A única real tradição viva, (org. Perfecto Cuadrado). Lisboa: Assírio \& Alvim, 1998, p. 379.
}

104 CESARINY, Mário "Na publicação da Antologia do cadáver esquisito", in A Intervenção Surrealista, Lisboa: Assírio \& Alvim, 1997, p.277.

${ }^{105}$ MELEAU-PONTY, Maurice. A natureza. São Paulo: Martins Fontes, 2006, p. 441. 
poema, foi, certamente, um dos modos mais evidentes em que se fez ver, no surrealismo, a interação entre vida e escrita: a vida passa a ser aquilo que uma pequena comunidade surrealista pode conceber em termos de criação.

Sobre Cruzeiro Seixas, os dados históricos são bastante mais escassos, certamente, isso se deve ao fato de que, em 1951, ele alista-se na Marinha Mercante, viaja para a Índia, para o extremo Oriente, e acaba por instalar-se em Angola até 1964. Quando começa a guerra colonial, ele decide retornar à Lisboa. Mesmo de volta à Portugal, Cruzeiro Seixas segue seu trajeto de maneira isolada, já que em 1978 ele se desentende com Cesariny ${ }^{106}$ e apenas em 2006, ano da morte deste, é que eles se reencontram para uma exposição conjunta.

A sua militância em relação ao surrealismo é, por tais motivos, relativa, muito embora, em entrevista recente (efetuada em novembro de 2011 e publicada em 2014), Cruzeiro Seixas reafirme o surrealismo como o seu programa de vida ${ }^{107}$ e, na esteira do que defendia Breton e Cesariny: "o surrealismo, acho eu, ultrapassa muito a noção estética que as pessoas têm dele. Mas ultrapassa muito. O surrealismo poderia ser um princípio político, porque a aspiração da liberdade e a cultura são duas coisas que têm de estar sempre ligadas"108 e, adiante: "Se não gosto do termo "intelectual, ainda gosto menos do termo 'artista'. Os pintores andam por aí todos contentes com a designação de artistas. Eu não! Eu não quero ser artista"109.

No catálogo da sua primeira exposição em Angola $^{110}$, há um apanhado de diversas citações que marcam a sua adesão ao surrealismo, entre elas, três citações do Breton, uma de Cesariny, uma de Rimbaud e uma de Lautréamont - deste último, justamente aquela que marca posição a favor do coletivo: "La poésie doit être faite par tous, non par un."111. Importa dizer que essa noção da poesia como um acontecimento coletivo defendida pelos surrealistas, permite que se pense o corpo como dotado de

\footnotetext{
${ }^{106}$ Cf. MARINHO, Maria de Fátima. O surrealismo em Portugal. Lisboa: Imprensa Nacional/Casa da Moeda, 1987, pp. 111, 112.

107 "Quando encontrar outro, estou absolutamente disposto a adoptá-lo. Mas com 91 anos já não é fácil encontrar”. LETRIA, José Jorge. Cruzeiros Seixas: A liberdade livre. Diálogo com José Jorge Letria. Lisboa: Guerra \& Paz, 2014, p. 41.

${ }^{108}$ Idem, p. 40.

${ }^{109}$ Idem, p. 82.

${ }^{110}$ ANEXO B , p. 228

${ }^{111}$ SEIXAS, Cruzeiro. "Na $1^{a}$ exposição de Cruzeiro Seixas em África" (do catálogo) in A Intervenção Surrealista. Lisboa: Assírio \& Alvim, 1997, p. 186.
} 
limites maleáveis, como será apresentado nos próximos capítulos, mediante a leitura dos poemas, e implica, muito mais do que a reunião grupal (que, como visto, foi bastante efêmera), uma ideia de sujeito poético.

É notável que grande parte das manifestações extra-poéticas de Cruzeiro Seixas quase nunca resultam da palavra própria, de forma que a noção de autoria é diluída e, por consequência, o sujeito da escrita aparece abalado em sua autonomia: o limite eu/outro é, então, flexibilizado, isto é, Cruzeiro Seixas aparece como signatário em meio a outros surrealistas em textos como "Do capítulo da probidade", de 1951 (no qual não se torna possível saber quem foi que escreveu o que) ou, como é o caso dos dois catálogos de suas exposições em África, em que seus textos são compostos por meio de citações, numa clara postura de fazer suas as palavras de outros, enfatizando, assim, o pressuposto coletivo do empenho surrealista, tal como se explicita na já mencionada citação de Lautréamont. No catálogo de sua segunda exposição ${ }^{112}$, tudo o que temos é a transposição de um longo trecho de Chants de Maldoror, de Lautréamont, no qual estão atualizados procedimentos de escrita tipicamente surrealistas, tais como a livre associação, o rompimento com a causalidade narrativa e com demais procedimentos lógicos do raciocínio.

O caso de Herberto Helder em relação ao surrealismo, exige uma longa abordagem. É bastante frequente encontrarmos entre os críticos do surrealismo menções acerca do envolvimento circunstancial de Herberto Helder no movimento, ou mesmo sugestões de adesões aos postulados que se manifestam na elaboração estética de seus poemas. Para Natália Correia, por exemplo, Herberto Helder faria parte daqueles escritores fortemente influenciados pelo surrealismo, com a ressalva de que, em sua poesia, "as determinantes surrealistas se diluem nas intensidades de um impressionante personalismo lírico"113. Perfecto Cuadrado também menciona o seu nome dentre os "autores ligados ao Surrealismo nas suas sucessivas reaparições, ressurreições e reencarnações em Portugal"114 . Maria de Fátima Marinho afirma:

(...) a produção de Herberto Helder não se esgota nas suas ligações

\footnotetext{
${ }^{112}$ ANEXO C, p. 230.

${ }^{113}$ CORREIA, Natália. O surrealismo na poesia portuguesa. Lisboa: Frenesi, 2002, p. 430.

${ }^{114}$ CUADRADO, Perfecto. "Uma divagação final (mais) abjectamente académica: notas sobre a poesia surrealista (portuguesa)" In: A única real tradição viva. (org. Perfecto Cuadrado). Lisboa: Assírio \& Alvim, 1998 p. 64
} 
com o surrealismo, abrangendo uma área mais vasta que atinge entre outras a poesia experimental e concreta. É, contudo, importante ressaltar que o autor de Apresentação do Rosto é um dos casos em que o surrealismo português alcança um nível mais elevado. Talvez porque não é puro, talvez porque Herberto Helder nunca pretendeu, teoricamente, ser surrealista, mas o foi, frequentemente, na prática. ${ }^{115}$

\section{O próprio Cruzeiro Seixas afirma:}

Não quero no entanto deixar de referir alguns dos nomes maiores do surrealismo daqui como António Maria Lisboa, Herberto Helder, Mário Henrique Leiria, António Dacosta, D’Assumpção, Ernesto Sampaio, Carlos Calvet, António Areal, Isabel Meyrelles, Raul Perez, Fernando Alves dos Santos, Mário Botas, etc, etc. ${ }^{116}$.

Ainda algumas palavras sobre a crítica: em sua tese de doutorado, Luis Maffei também se ocupará dessa reflexão, apontando para a síntese imagética presente em $O s$ brancos arquipélagos, como efeito de um modo de composição onírico. Maffei tem, entretanto, em vista a recusa de Herberto Helder diante de qualquer "escola" de pensamento ou literária e, assim, acerca das características supramencionadas, afirma:

Por tudo isso, não temo muito afirmar que é justamente por ser "contrário a escolas" que Herberto Helder pode, de modo talvez lúdico como o da "oficina" iludida de Do mundo, jogar com as heranças que quiser, recolhendo-as como a sua poesia apeteça e não tendo a mais pequena obrigação de uma coerência que seria, a todos os títulos, pequena, tola. ${ }^{117}$

Para discorrer sobre as aproximações e os distanciamentos que $\mathrm{HH}$, alternadamente, manteve em relação ao surrealismo, importa retomar os termos nos quais o Abjeccionismo se define, de modo que a participação de Herberto Helder nas reuniões do Café Gelo, como mencionei acima, já encontrará alguma justificativa.

O primeiro ponto elencado por Pedro Oom a respeito do abjeccionismo, como visto, a ênfase na posição individual em detrimento da obediência a pressupostos que

${ }^{115}$ MARINHO, Maria de Fátima. O surrealismo em Portugal. Lisboa: Imprensa Nacional/Casa da Moeda, 1987, p. 289. Em livro dedicado a Herberto Helder, a estudiosa oferece diversas referências surrealistas em sua obra (Cf. MARINHO, Maria de Fátima. Herberto Helder: a obra e o homem. Lisboa: editora Arcádia, 1982, p. 27, pp.29, 30, p. 159, p. 207-213.) e, E mais recentemente, num trecho de artigo cujo subtópico (que também é a sua conclusão...) se intitula "Herberto Helder é e não é um poeta surrealista", Maria Estela Guedes faz uma defesa de um surrealismo não escolar em Herberto Helder (Cf. GUEDES, Maria Estela. "Dois textos" in IDEIA: revista de cultura libertária, no 71/72, Évora: novembro de 2013, p. 78-81, consultado virtualmente em http://colectivolibertarioevora.files.wordpress.com/2013/12/a-ideia-71-72.pdf)

${ }^{116}$ SEIXAS, Cruzeiro. "Carta inútil e comunicação quase automática" in A IDEIA: revista de cultura

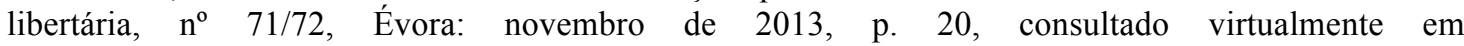
http://colectivolibertarioevora.files.wordpress.com/2013/12/a-ideia-71-72.pdf.

${ }^{117}$ MAFFEI, Luis. Do mundo de Herberto Helder. Tese de doutoramento em Letras Vernáculas. Rio de Janeiro, Faculdade de Letras/UFRJ, 2007, p. 54. 
venham a reger uma coletividade determinada, já nos oferece argumento de peso para justificar a espécie de envolvimento que Herberto Helder mantém com o abjeccionismo neste momento, já que, de forma bastante incisiva, o poeta se pronuncia em Photomaton \& Vox: “A poesia é feita contra todos, e por um só; de cada vez, um e só" ${ }^{118}$, marcando, de uma vez por todas, a divergência da concepção adotada pelos surrealistas, que, como Cruzeiro Seixas, recuperam as palavras de Lautréamont, palavras que, tais como apropriadas por $\mathrm{HH}$, se transformam no seu oposto. Essa individuação do sujeito da escrita, entretanto, pode encontrar justificativa mais pela recusa em participar das polêmicas surrealistas (os surrealistas portugueses, assim como os franceses, embora levantassem a bandeira da liberdade a qualquer custo, eram bastante rígidos quanto aos critérios de estabelecimento de seus postulados - no caso de Portugal essa postura ortodoxa é praticada especialmente por Mário Cesariny - o que redundou numa série de desentendimentos entre alguns dos participantes do grupo e a consequente expulsão ou abandono de outros), do que numa antipatia em relação ao ideal surrealista, já que, conforme atesta Maria de Fátima Marinho:

(...) quando em 1952 começaram a aparecer publicados seus primeiros textos [de Herberto Helder], a atmosfera literária lisboeta e portuguesa acabava de ser agitada pelas actividades e polémicas dos dois grupos surrealistas de Lisboa (...) era natural, pois, que a obra de Herberto Helder se 'ressentisse' dessas ideias e processos. ${ }^{119}$

Nesse mesmo sentido, Maria Estela Guedes apresenta o trecho de um documento assinado por Herberto Helder e Máximo Lisboa que diz o seguinte:

[Os abaixo assinados] Recusam a denominação de "surrealistas" que alguma crítica, por desatenção e desocupação, lhes atribuiu ou atribuirá. Aceitam do surrealismo a proposta de uma liberdade tão grande que nela caiba mesmo uma atitude "anti-surrealista". Aceitam do surrealismo todos os primados que se encontram com a dignidade humana e a Alegria de Viver, garantia (consideram) de uma posição ética fundamental diante da mesma vida. Aceitam do surrealismo - para amor e admiração secreta e pública - os actos, obras e morte de alguns exemplificadores que foram surrealistas, quando isso os identificou com a sua pessoal vocação de homens livres. Recusam, finalmente, o surrealismo onde ele não pode ser isso. Recusam-no como escola, como prisão, como antologia, como

\footnotetext{
${ }^{118}$ HELDER, Herberto. Photomaton \& Vox. Lisboa: Assírio \& Alvim, p. 153.

${ }^{119}$ MARINHO, Maria de Fátima. Herberto Helder: a obra e o homem. Lisboa: editora Arcádia, 1982, p. 208.
} 


\section{Chiado. $^{120}$}

Sugerimos, então, que a recusa do surrealismo atestada por Herberto Helder incide justamente na sua defesa em favor da liberdade de posicionamento individual (fato que se confirma se atentamos para a seguinte declaração: "Breton era um sargento rancheiro, um sargento irascível e peremptório. Ou comiam daquilo, todos, ou levavam

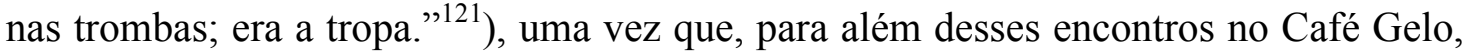
Herberto Helder sempre manteve relações com poetas do surrealismo, relações que passam necessariamente pela literatura enquanto prática subversiva. Nesse sentido, nota-se a ênfase na valorização da individualidade presente em cada um dos autores surrealistas; como Herberto Helder explicita no caso do prefácio que escreve para António José Forte ${ }^{122}$, em que afirma:

O tributo ao surrealismo - pauta imaginística, sopro metafórico, erotismo mágico, visão apocalíptica do quotidiano ou fé na salvação dentro da história através da utopia - não viola o seu universo pessoal e o esquema que o traveja. Esses aspectos conformam-se a características privadas suas. ${ }^{123}$

O mesmo empenho de valorização do indivíduo no ato da criação também aparece, em texto de 1963 com post-scriptum em 1999, sobre a poesia de Edmundo de Bettencourt ${ }^{124}$, poeta que, tendo transitado entre os presencistas e, portanto, deslocado do grupo surrealista é qualificado por Herberto Helder como surrealista num sentido muito preciso: "Surrealismo é uma incómoda designação escolar que os surrealistas nos forneceram. Não será surrealista (despido o termo do equívoco geracional) todo aquele que transpôs a noção tradicional de realidade (...)?"125. Diz ainda:

\footnotetext{
${ }^{120}$ GUEDES, Maria Estela. "Dois textos” in IDEIA: revista de cultura libertária, $\mathrm{n}^{\mathrm{o}}$ 71/72, Évora: novembro de 2013, p. 80, consultado virtualmente em: http://colectivolibertarioevora.files.wordpress.com/2013/12/a-ideia-71-72.pdf.

${ }^{121}$ HELDER, Herberto. "Herberto Helder: entrevista" In: Inimigo Rumor. Rio de Janeiro, Lisboa: Cotovia, 7 Letras, Angelus Novus, nº 11, p. 190-197, 2ºmestre de 2001, p. 194.

${ }^{122}$ ANEXO D, p. 234.

${ }^{123}$ HELDER, Herberto. "Nota inútil” In: FORTE, António José. Uma faca nos dentes. Lisboa: Parceria A. M. Pereira, 2003, p.15.

${ }^{124}$ ANEXO E, p. 239.

${ }^{125}$ Sobre isso, importa frisar, nesse mesmo trecho, a seguinte afirmação de Herberto Herlder:. (HELDER, Herberto. "Relance sobre a poesia de Edmundo de Bettencourt" in Poemas de Edmundo de Bettencourt. Lisboa: Assírio \& Alvim, 1999, p. 21).
} 
(...) hoje deslocou-se a capacidade criadora do indivíduo para a comunidade, crendo que o indivíduo é apenas uma flexão do poder criador dela (...). Se a instituição fosse, por definição, uma categoria revolucionária, é evidente que tudo estaria certo, mas a verdade é que ela representa o ordenamento congelado do impulso que lhe deu origem (...) o movimento é qualidade da imaginação, quer dizer, atributo da individualidade - ao contrário da fixação institucional, da ordem, que é atributo da razão, quer dizer, atributo da comunidade. É a esta individualidade que se recorre para ultrapassar o estatismo da instituição. ${ }^{126}$

A mesma perspectiva aparece quando discorre sobre uma pintura de Cruzeiro Seixas ${ }^{127}$ : “O talento é a possibilidade da pessoalidade (...). O talento é cada um.

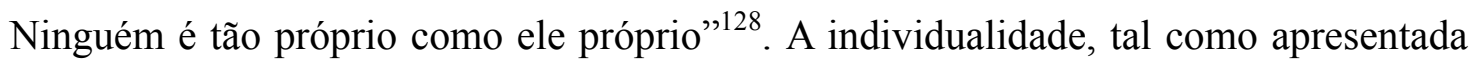
por Herberto Helder é sinônimo de liberdade, uma liberdade que não poderia ocorrer verdadeiramente caso regulada por um credo ortodoxo ou por preceitos quaisquer, como era o caso da prática corrente do movimento surrealista português. A liberdade de que os surrealistas foram porta-vozes enfáticos, na visada de Herberto Helder, só poderia se manifestar verdadeiramente para além do surrealismo.

$\mathrm{Na}$ Antologia Surrealista do Cadáver Esquisito encontramos, porém, um texto de 1957 produzido coletivamente e assinado por Herberto Helder, João Rodrigues e José Sebag ${ }^{129}$, em que nos deparamos não apenas com uma sintaxe inusitada, com a livre associação de imagens responsável pelo rompimento com a lógica tradicional, mas também com um tom bastante subversivo, como é de praxe entre os surrealistas. Vale reproduzir um trecho em que o aspecto coletivo se evidencia mais enfaticamente pelo uso da primeira pessoa do plural:

(...) recusamos a casa da misericórdia, a viagem pacífica, o artigo de fundo, a teoria do espaço curvo (...). Aceitamos o algodão de rama, bem como o iodado, alguns nomes escolhidos ao acaso nos arquivos de identificação enquanto só nomes; nomes feios, pronomes, alguns substantivos cómodos, a ira, aceitamos a confusão $(. . .)^{130}$

\footnotetext{
${ }^{126}$ Idem, pp. 12, 13.

${ }^{127}$ ANEXO F, p. 253.

${ }^{128}$ HELDER, Herberto. Cena vocal sobre fundo visual de Cruzeiro Seixas. Lisboa: Diário de Notícias, 19 de junho de 1980.

${ }^{129}$ ANEXO G, p. 256.

${ }^{130}$ CESARINY, Mário. Antologia do cadáver esquisito. Lisboa: Assírio \& Alvim, 1989, p. 69.
} 
Em texto de jornal em homenagem a Manuel de Castro (por ocasião da morte deste), reproduzido por Maria Estela Guedes na revista A IDEIA 73/74, lemos Herberto Helder, em tom confessional, a respeito dessa atividade conjunta praticada pelos poetas em torno dos cafés: "Éramos bastante jovens e andávamos todos à procura. Alguns outros aproximavam-se para ver. Mas naquela sociedade canibal, os que não estavam dispostos a deixarem-se devorar contavam-se por não muitas caras." "131, de forma que a atuação coletiva parece ter desempenhado importância decisiva no percurso de Herberto Helder, de tal modo que a expressão de que se utiliza - sociedade canibal - ressalta, a um só tempo, a implicação relacional/coletiva desse momento, bem como uma certa voracidade nas maneiras de estar com o outro, a ponto de se utilizar de uma metáfora (essa espécie de fome devoradora) que revela, inclusive, a poesia como uma necessidade fisiológica.

Ora, esse aparente impasse que surge da sua posição marcadamente pessoal e a sua participação num cadáver esquisito pode ser amenizado se levarmos em conta a leitura de alguns poemas (o que será feito nos capítulos seguintes), em que poderemos flagrar uma postura ambígua no que se refere à constituição do indivíduo. Como poderemos notar, não se trata nunca de uma defesa da coletividade, mas, numa visada menos institucional (e como instituição ele qualifica o surrealismo, como vimos há pouco), de uma ideia de indivíduo que é complexificada na relação com o outro.

Desse modo, acreditamos que a diferença entre a postura pessoalista característica de Herberto Helder, num extremo, e a postura coletivista característica dos surrealistas no extremo oposto, incidem muito mais sobre a definição dos respectivos campos de atuação escrita de um e de outros, do que sobre a importância que a alteridade assume na constituição do sujeito da escrita, como veremos mais adiante. Nesse sentido, acredito serem plenamente adequadas as reflexões de MerleauPonty sobre essa problemática: “(...) como a minha imagem capta o meu ato de tocar, a imagem visual dos outros também o capta: eles são também o fora de mim. E eu sou o interior deles. Eles me alienam e eu os incorporo. Eu vejo pelos olhos de outrem - o mundo" $" 132$.

\footnotetext{
${ }^{131}$ HELDER, Herberto. "Eu que apareci acidentalmente vivo" In: A IDEIA. Lisboa: $\mathrm{n}^{\circ} 73 / 74, \mathrm{p} .34-35$, outono de 2014, p. 34.

${ }^{132}$ MELEAU-PONTY, Maurice. A natureza. São Paulo: Martins Fontes, 2006, p. 440.
} 
A grande diferença entre Herberto Helder e os surrealistas ortodoxos ${ }^{133}$ quanto à questão "pessoalidade versus coletividade" é, portanto, a lucidez do olhar que Herberto Helder conseguiu manter em relação à ideia de liberdade: os surrealistas, uma vez submetidos aos pressupostos que regiam o movimento, corriam o risco de serem aprisionados ao que poderia ter se tornado a instituição surrealista. É bem verdade, porém, que nem Cesariny nem Cruzeiro Seixas sucumbiram a essa ameaça no que se refere a formalização poética, apresentando, respectivamente - e cada um com a individualidade criativa que lhe cabe, como ficará claro, no momento de leitura dos poemas - uma obra poética única e diversificada que, certamente extrapola os princípios do automatismo psíquico ou qualquer outro credo surrealista dos quais, contraditoriamente, eles mesmos foram porta-vozes.

Importa trazer uma última citação de Photomaton \& Vox, que mostra ainda mais essa complexidade da relação eu/outro tal como aparece em Herberto Helder - e aqui, alcança, inclusive, algumas reflexões que desenvolveremos nos próximos capítulos sobre o corpo próprio e o espaço: “O que está por fora corresponde ao que está por dentro, quando deveria ser: o que está por fora é o que está por dentro" ${ }^{134}$. Ora, a noção dessa fronteira movediça, como figura em Merleau-Ponty, redunda numa significação ontológica: a recusa do puro objeto ${ }^{135}$, de modo que subjetividade e objetividade tornam-se, como vimos, noções permeáveis, já que se interferem e se determinam mutuamente. Nas palavras do filósofo: “(...) em vez de ciência do mundo por relações contempladas desde o exterior (relações de espaço, por exemplo), o corpo é o mensurador do mundo, eu estou aberto para o mundo (...)"136.

Retomando o segundo ponto assinalado por Pedro Oom, quando este fala sobre o Abjeccionismo no sentido da abjeção a que são submetidos os portugueses naquele momento de grande hostilidade política, também é possível estabelecer um paralelo com eventos que envolveram Herberto Helder, o que justifica, mais uma vez, a sua aproximação em direção aos surrealistas por essa espécie de comunhão subversiva

\footnotetext{
133 E entre os surrealistas ortodoxos incluem-se tanto Mário Cesariny quanto Cruzeiro Seixas: ambos signatários de polêmicas diversas envolvendo a crítica e outros poetas. Sobre isso, vale conferir Pacheco Versus Cesariny e Jornal do Gato.

${ }^{134}$ HELDER, Herberto. Photomaton \& Vox. Lisboa: Assírio \& Alvim, p. 74.

${ }^{135}$ Cf. MELEAU-PONTY, Maurice. A natureza. São Paulo: Martins Fontes, 2006, p. 344

${ }^{136}$ Idem, p. 350.
} 
contra um ambiente extremamente repressor: os surrealistas foram vítimas constantes de censura por parte dos órgãos encarregados de garantir a permanência da ditadura salazarista $^{137}$. No caso de Herberto Helder, temos notícias de dois incidentes: em estudo de Diana Pimentel, lemos que Apresentação do rosto é retirado de circulação pela censura em $1968^{138}$ e, quase simultaneamente, vem a decisão de Herberto Helder de excluir o livro do conjunto total de sua obra ${ }^{139}$. Sabemos que, embora o livro nunca mais tenha sido reeditado, a reapropriação de suas partes em livros posteriores ${ }^{140}$ pode ser lida como um atestado dessa postura subversiva em relação à censura, um ato de desobediência, de afrontamento político. Nesse mesmo ano, conforme relata Maria de Fátima Marinho, "Participou, como intermediário entre editor e tradutor, na publicação do livro Filosofia na Alcova do Marquês de Sade. Por isso teve um processo judicial,

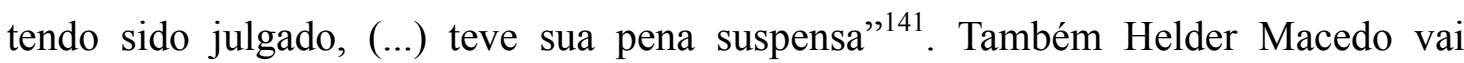

\footnotetext{
${ }^{137}$ Adelaide Ginga apresenta uma listagem de diversos nomes atuantes do surrealismo que tinham suas fichas no PIDE (Polícia Internacional e de Defesa do Estado), onde constam, inclusive, o nome de Mário Cesariny e de Cruzeiro Seixas. (Cf. TCHEN, Adelaide Ginga. A Aventura Surrealista. Lisboa: Colibri, 2001, p. 187-204). Também António Cândido Franco narra que em 1953 "É-lhe [ao Cesariny] aplicada, pelos serviços da Secção Central da Polícia Judiciária de Lisboa, pena de cinco anos de liberdade vigiada, por 'suspeito de vagabundagem."'. (FRANCO, António Cândido. Mário Cesariny: Cartas para a casa de Pascoaes. Vila Nova de Famalicão: Documenta, Fundação Cupertino de Miranda, 2012, p. 245.)

${ }^{138}$ Conforme documento (ANEXO H, p. 259), acessado a partir da Biblioteca e arquivo de José Pacheco Pereira, disponível em: http://ephemerajpp.com/2012/01/25/censura-relatorio-no-8243-22-dejulho-de-1968-relativo-a-apresentacao-do-rosto-de-herberto-helder-censorship-report-no-8243-july-221968-on-apresentacao-do-rosto-of-herberto-helder/.
}

${ }^{139}$ PIMENTEL, Diana. Ler a voz, ver o rosto: uma polaroide de Herberto Helder. Porto: Campo das Letras, s/d, p.46. Sobre isso, o próprio Herberto Helder irá se pronunciar de maneira bastante irônica em Photomaton \& Vox: "Imagine-se agora que pretendo apresentar-me o meu próprio rosto. Estou logo metido num caso policial. Colecciono pormenores e suspeitas, sigo uma pista que abandono, volto ao começo que já não é o mesmo começo mas o começo de outros começos. Uma confusão. Evidentemente não se chega a descobrir coisa alguma. Todos os crimes são crimes perfeitos" (HELDER, Herberto. Photomaton \& Vox. Lisboa: Assírio \& Alvim, 2006, pp. 129, 130). Essa alusão ao crime, no entanto, ganha outra possibilidade interpretativa, quando se considera o crime não mais como referência ao fato empírico da censura, mas como resultado do percurso autobiográfico: nesse sentido, a investigação acerca da própria identidade pode ser lida como algo que viola o interdito, subverte a proibição, importa enfatizar, pela escrita (daí a força da ironia que ressaltamos há pouco). É exatamente nesse sentido que investe Manuel de Freitas ao longo de seu ensaio Uma espécie de crime, tal como nos deixa entrever no "Átrio", com que começa a tecer suas considerações: "Estamos, por assim dizer, no cenário de um crime iminente em que o revólver (simultaneamente apontado ao autor e ao leitor) se chama escrita." (FREITAS, Manuel de. Um espécie de crime: Apresentação do Rosto de Herberto Helder. Lisboa: \& etc, 2001, p. 11).

${ }^{140}$ As informações acerca do destino das partes de Apresentação do rosto podem ser encontradas em: FREITAS, Manuel de. Uma espécie de crime: Apresentação do rosto de Herberto Helder. Lisboa: \& etc, 2001, pp. 21, 22.

${ }^{141}$ MARINHO, Maria de Fátima. Herberto Helder: a obra e o homem. Lisboa: editora Arcádia, 1982, p. 15. 
mencionar o seguinte fato:

O que o Café Gelo da segunda metade dos anos 50 pode ter significado certamente não é definível em termos políticos partidários. Mesmo quando (ou sobretudo quando), por exemplo, o Herberto Helder e eu nos encontrámos envolvidos, em 1958, numa desarrumada tentativa de golpe revolucionário que teria metido armas... se tivesse acontecido. Mas o O'Neill já tinha dito, o que nesse tempo acontecia não acontecia. ${ }^{142}$

O terceiro ponto assinalado por Pedro Oom - a crença em que a dissolução das antinomias não seria um impeditivo para o surgimento de novas antinomias, o que redunda num movimento incessante com a consequência de uma perpétua substituição nos modos relacionais - pode ser, de certa maneira, associado à constância com que a ideia de metamorfose aparece na obra de Herberto Helder. "Teoria das cores", situado em Os passos em volta (publicação brasileira de 2005), apresenta-se como um texto ${ }^{143}$ exemplar nesse sentido: versa sobre um pintor desejoso de retratar com fidelidade um peixe num aquário e, durante a observação que precede o retrato, percebe a inusitada mudança de cor que o peixe começa por sofrer (efetuar?) - do vermelho para o preto -, decidindo então pintá-lo de amarelo, por haver compreendido esta outra espécie de fidelidade:

Ao meditar sobre as razões da mudança exatamente quando assentava na sua fidelidade, o pintor supôs que o peixe, efetuando um número de mágica, mostrava que existia apenas uma lei abrangendo tanto o mundo das coisas como o da imaginação. Era a lei da metamorfose. ${ }^{144}$

A metamorfose, entretanto, não figura apenas como um tema recorrente em sua obra, mas revela uma adesão do próprio poeta, no seu fazer poético, a esta lei, uma vez

\footnotetext{
${ }^{142}$ MACEDO, Helder. "A utopia da negação”, Arte \& Utopia (Ed Margarida Acciaiuoli, Ana Duarte Rodrigues, Maria João Castro, Paula André, Paulo Simões Rodrigues) CHAIA; DINÂMICA'CET-IUL; FCSH, Lisboa, 2013 (pp. 237-244), p. 241.

${ }^{143}$ Vale aqui esclarecer a nomeação de que lançamos mão: 'texto', já que, como o próprio autor adverte sobre o livro em entrevista concedida a Fernando Ribeiro de Mello, publicada do Jornal de Letras e Artes n. ${ }^{\circ}$ 139, de 17 de Maio de 1964: "Inscrevê-lo na designação de contos, ou chamar aos meus outros livros conjuntos de poemas, significa apenas ausência de superfície às categorias estabelecidas. Não me parece necessário referir a crise das classificações literárias. Caminha-se, sabemo-lo todos, para uma visão total da obra literária que se não podem adoptar distinções afinal nunca rigorosas, senão de um ponto de vista didáctico e, assim mesmo, somente em determinado grau de didactismo, «Os Passos em Volta» são a minha primeira tentativa para superar a dictomia prosa-poesia." ( http : // editora - afrodite. blogspot. com/ 2007/09/entrevista-herberto-helder.html).
}

${ }^{144}$ HELDER, Herberto. Os passos em volta. São Paulo: Azougue Editorial, 2005, pp. 21, 22. 
que este mesmo trecho do texto, datado de 1963 e publicado em Vocação animal, apresenta a seguinte versão:

Ao meditar acerca das razões por que o peixe mudara de cor precisamente na hora em que o pintor assentava na sua fidelidade, ele pensou que, lá de dentro do aquário, o peixe, realizando o seu número de prestidigitação, pretendia fazer notar que existia apenas uma lei que abrange tanto o mundo das coisas como o da imaginação. Essa lei seria a metamorfose. ${ }^{145}$

Vê-se que o próprio texto sofreu uma metamorfose de 1963 a 2005. Em verdade, essas modificações textuais são bastante comuns em H.H ${ }^{146}$. Como bem aponta Maurício Salles, em Herberto Helder há grande clareza a respeito do inacabamento da linguagem ${ }^{147}$, e afirma ainda:

o elemento de autoposição do escrito como trabalho em continuidade, próprio de uma não obra (poderia pontuar Blanchot), sempre a ser reunido, ainda não encerrado, não fixado nas miragens da autoria e da cultura, uma vez que sua totalização está sendo revista e repensada em função do conjunto e de suas conjunções no tempo. ${ }^{148}$

Herberto Helder aplica assim, um procedimento semelhante ao dos surrealistas, quando estes efetuam a manipulação de $\operatorname{textos}^{149}$ : textos próprios ou alheios: como o próprio poeta faz questão de frisar a respeito de suas traduções, poemas mudados para

\footnotetext{
${ }^{145}$ HELDER, Herberto. Vocação Animal, "Coleção Cadernos de Poesia”. Lisboa: Publicações Dom Quixote, 1971, p.12.

${ }^{146}$ Para uma visão mais ampla do tema, vide Herberto Helder: A obra e o homem, de Maria de Fátima Marinho, onde a autora tece uma diversidade de considerações acerca das variações presentes nas diferentes edições dos textos de HH.
}

${ }^{147}$ Cf. VASONCELOS, Maurício Salles. Espiral terra - poéticas contemporâneas de língua portuguesa. Tese de livre-docência. São Paulo: FFLCH-USP, 2010, p. 199.

${ }^{148}$ Idem, pp. 10, 11.

${ }^{149}$ Os surrealistas portugueses lançaram mão de métodos de criação definidos pela prática de alguns exercícios; entre eles a manipulação de textos tradicionais que, juntamente com o Inventário, o Cadáver esquisito e a Colagem, eram motivadores de relações inusitadas entre significados. No caso da manipulação de textos, a proposta consistia no estabelecimento de regras prévias de modificação de poemas e textos da literatura (alterações de palavras, fonemas, idiomas, etc), como no exemplo de António Domingues e Alexandre O'Neill que, a partir da seguinte quadra portuguesa: “À entrada da Borralha/ logo à casa primeira/ hei-de colher uma rosa/ sem pôr as mãos na roseira", passando pela fase intermediária de destruição do sentido lógico: "Pá bemprata na pupalha/ togo pá bala crimeita/ lei-se doer uma gosa/ bem flor lãs mãos na toleira", para finalmente chegar em: "Estava, em prata, sobre a palha/ E outro na gala caseira/ Nua, a doer, gosa a lei/ A flor das mãos na poeira" (DOMINGUES, António \& O’NEILL, Alexandre. In: A única real tradição viva. (org. Perfecto Cuadrado). Lisboa: Assírio \& Alvim, 1998 p. 51). 
o português (Doze nós numa corda, Poemas ameríndios, Oulof, As magias, O bebedor nocturno). Em Oulof, HH inicia com uma epígrafe do poeta belga Henri Michaux que diz o seguinte: "Saisir: traduir. Et tout est traduction à tout niveau, em toute direction" 150 , ora, a compreensão, deste ponto de vista, é sinônimo do ato de traduzir e, estendendo a definição ao lado de H.H., sinônimo do ato de mudar, modificar, metamorfosear: o movimento é, portanto, incessante.

Todas essas convergências, entretanto, jamais impediram Herberto Helder de proferir algumas palavras bastante severas acerca do surrealismo, como aquelas que encontramos em Photomaton \& Vox: "Nunca há surrealismo, porque o surrealismo que houver será sempre uma 'descrição do mundo' (Juan Matus), em que se implica um preconceito gradual ou termométrico da realidade" $" 151$ e, com mais contundência:

Põe-se uma vaca a ruminar a estrela de Arcturus. Mas há um nevoeiro luminoso que ninguém toca, há as fibras transparentes da morte, e o terrorismo angélico - enquanto os contemporâneos comem do que nem podem e cagam-se nas cadeiras terrestres. $\mathrm{O}$ surrealismo faz parte dessa merda. ${ }^{152}$

Nota-se, nesses trechos, a acidez irônica com a qual Herberto Helder se refere ao surrealismo. Essa ironia apenas camufla um ponto de vista bastante radical: como sugere Herberto Helder, o surrealismo - que se apresenta como o grande desestabilizador da lógica organizacional do mundo moderno - estaria baseado numa ideia preconcebida acerca da realidade, de forma que uma postura verdadeiramente libertária veria a própria realidade factual como um constructo e, assim, esta não poderia se distinguir de qualquer surrealidade ou manifestação criativa que supõe um rompimento com o referencial. Em outras palavras, Herberto Helder toma para a si a posição de que não há, absolutamente, um referencial de realidade, apenas elaborações forjadas (isto é, a própria realidade seria uma construção), anulando, desse modo, o solo do real sobre o qual a subversão surrealista se justificaria. Eis um trecho passível dessa interpretação: "Olha, olha: eles sabem o que é a realidade! Pergunto onde aprenderam, que eles são dos que aprendem. Meninos, onde está afixado o cartaz:

\footnotetext{
${ }^{150}$ HELDER, Herberto. Doze nós numa corda - poemas mudados para o português. Lisboa: Assírio \& Alvim, 1997, p. 7.

${ }^{151}$ HELDER, Herberto. Photomaton \& Vox. Lisboa: Assírio \& Alvim, 2006, p. 64.

${ }^{152}$ Idem, Ibidem.
} 
ISTO É A REALIDADE -?",153.

Se iniciamos este tópico com uma breve história do surrealismo, passando respectivamente por Mário Cesariny, Cruzeiro Seixas e concluímos mediante a apresentação da alternância entre aproximação e distanciamento na relação de Herberto Helder com o surrealismo; começaremos o tópico seguinte, inversamente, com uma exposição dos discursos acerca do corpo primeiramente em Herberto Helder. Isso porque nele, mais do que em Cesariny ou em Cruzeiro Seixas, o corpo aparece insistentemente como argumento que sustenta a criação poética.

\section{O corpo poemático, o corpo existencial, os corpos surrealistas}

A atestada evidência da relação ambígua que Herberto Helder mantém com o surrealismo (a saber: crítica do movimento e elogio da liberdade, elogio das possibilidades de elaboração criativa que advém dessa liberdade - além da postura, ora de aproximação, ora de distanciamento em relação aos membros do surrealismo português), cede lugar a uma espécie de comunhão se levarmos em conta que, nos trechos em que discorre sobre a temática surrealista ou sobre poetas filiados ao movimento, frequentemente lança mão de metáforas corporais.

No pequeno texto em que discorre sobre o talento intitulado "Cena vocal com fundo visual de Cruzeiro Seixas"154, lemos o seguinte: "E o nosso corpo que é o fremente corpo das imagens, as imagens encarnadas, impõe a emenda do mundo." ${ }^{\prime 55}$, numa clara confluência em relação à noção de carne como elemento relacional, subjetivo/objetivo (já que o sujeito/corpo se constitui mediante o mundo, ao mesmo tempo em que constitui esse mundo, ou, nas palavras de $\mathrm{HH}$, impõe sua emenda...), exatamente como pudemos ler em Merleau-Ponty. Ainda sobre Cruzeiro Seixas: "O Atelier de Cruzeiro Seixas: Astro assoprado, sombria ligeireza, dom: eu sei. Nada me

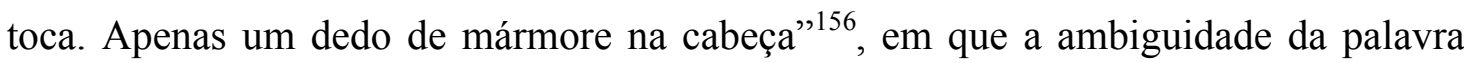

\footnotetext{
${ }^{153}$ Idem, p. 115.

${ }^{154}$ ANEXO F, p. 253.

${ }^{155}$ HELDER, Herberto. Cena vocal sobre fundo visual de Cruzeiro Seixas. Lisboa: Diário de Notícias, 19 de junho de 1980.

${ }^{156}$ HERLDER, Herberto (citação sem fonte). In: ENTRE. Lisboa: $n^{\circ}$ 5, inverno de 2014, p. 74
} 
“tocar” (por a mão em algo ou ser comovido por algo) é logo intensificada pela figuração do dedo de mármore que incide sobre a cabeça, de forma que se pode supor a comoção, como fruto do contato entre os corpos. Sobre a poesia de Edmundo de Bettencourt ${ }^{157}$, poeta que, como vimos anteriormente, ele qualifica como surrealista dada a sua vocação de liberdade, lemos: "Há uma nova realidade. É o poema. Assim é que se pode dizer possuir o poema existência tão própria, independente e suficiente como um corpo." ${ }^{158}$. Sobre "sombra de almagre" de serigrafia, lemos: "No momento-Cesariny, este, há uma aurora dada-equinocialsurrealista que aclara, pelo método antinômico da obscuridade, a vida dos nomes e das coisas, as relações entre nomes e nomes, coisas e coisas, e a religião geral, nova, renova, cabeças, entranhas, dedos." ${ }^{~ 160}$, de modo que as partes do corpo, como indica Herberto Helder, seriam a matéria vocabular desse texto vital, que permitiria uma religação com a existência ${ }^{161}$.

Tais metáforas e comparações, como rapidamente demonstram as citações acima, indicam a um só tempo, o corpo enquanto subjetividade materializada na criação artística, bem como o texto criativo enquanto corpo orgânico com metabolismo autônomo (numa evidente subversão da ideia da escrita referencial). Mais do que isso, elas servem de vínculo entre a poesia surrealista portuguesa e a poesia de Herberto Helder, já que esta é, ela própria, carregada de metáforas corporais, como fica evidente nas seguintes formulações que encontramos em Photomaton \& Vox: “A mão pensa (...). Mão está diferente, indiferente. Começa a pensar, primeiro lenta, e depois com mais força e velocidade"162, e, ainda: "Eu, esta mão." ${ }^{\text {"163 }}$. Ora, se não é isso exatamente uma clara subversão do postulado da razão absoluta cartesiana? A mão, corpo que é,

\footnotetext{
${ }^{157}$ ANEXO E, p. 239.

${ }^{158}$ HELDER, Herberto. "Relance sobre a poesia de Edmundo de Bettencourt" in Poemas de Edmundo de Bettencourt. Lisboa: Assírio \& Alvim, 1999, p. 20.
}

\footnotetext{
${ }^{159}$ ANEXO I, p. 260.

${ }^{160}$ HELDER, Herberto. "Cesariny sombra de almagre”. A Phala, 1\#, 2007, p. 57.

${ }^{161}$ Também Luiz Pacheco atenta para o caráter fortemente corporal da escrita de Cesariny, como podemos ler na epígrafe de Comunidade: “A Mário Cesariny de Vasconcelos, Poeta do Corpo" (Cf. PACHECO, Luiz \& COELHO, Teresa Dias. Comunidade. Lisboa: Contexto Editora, 1980).

${ }^{162}$ HELDER, Herberto. Photomaton \& Vox. Lisboa: Assírio \& Alvim, p. 50.

${ }^{163}$ Idem, p. 53.
} 
elevada à categoria definidora do sujeito, comporta em si as propriedades do pensamento, e, mais além, é ela mesma manifestação do eu: subjetividade encarnada .

Nessa mesma esteira, encontramos a seguinte reflexão: “A dúvida da correspondência correcta da cabeça - eis outro problema. Portanto, cada vez menos sei se posso ser, porque (nas circunstâncias) o 'penso, logo existo' cai pela base, digamos, da própria cabeça."164. O "penso, logo existo" de Descartes é aqui questionado pela evidência da materialidade dessa cabeça que, apenas pelo pensamento não pode garantir ao sujeito existência própria. Cabe dizer que, conforme a leitura de Maria de Fátima Marinho, haveria neste texto uma alusão a um fato da biografia de Herberto Helder: “1972 - Em Junho sofre um acidente de viação, em consequência do qual esteve hospitalizado seis meses" ${ }^{\text {165 }}$, desde 1971, Herberto Helder esteve em Angola, e as referências à África presentes no texto, confirmam a correspondência ao fato empírico $^{166}$, conforme sugestão da pesquisadora. Esse dado não invalida, no entanto, o questionamento à lógica cartesiana presente no trecho, uma vez que a materialidade do corpo - cabeça - é que passa a ser a garantia de existência do sujeito e, em se tratando de um corpo/cabeça acidentado, a garantia de existência fica abalada.

Há um momento, ainda, em que Herberto Helder questiona a cultura e a condena enquanto porta-voz da castração criativa - as características da cultura são vistas aqui numa vertente muito semelhante às características da razão enquanto instituição -, uma vez que, de acordo com o poeta, a cultura seria um impeditivo da contradição e esta, por sua vez (obedecendo à mesma lógica argumentativa dos surrealistas), seria o ponto máximo de ampliação das possibilidades relacionais e, portanto, perceptivas:

A cultura é uma operação de empobrecimento da revelação. Compreenda-se: a cultura é a moral da imaginação; fecha prudentemente a excessiva abertura da linguagem, a formulação entusiástica do símbolo. Quem está fora da cultura propicia-se à revelação. A revelação é um puro espaço de contradição; e só a

${ }^{164}$ HELDER, Herberto. Photomaton \& Vox. Lisboa: Assírio \& Alvim, p. 123.

${ }^{165}$ MARINHO, Maria de Fátima. Herberto Helder: a obra e o homem. Lisboa: editora Arcádia, 1982, p.16.

${ }^{166}$ Conforme consta em Photomaton \& Vox: "Engenheiros de cabeça estiveram em África a olhar para dentro da minha, mas fazia muito calor e, com calor, que se pode pedir da atenção veloz ao longo de um hospital cheio de cabeças?" (HELDER, Herberto. Photomaton \& Vox. Lisboa: Assírio \& Alvim, 2006, p. $123)$. 
contradição é abrangedora bastante para conter as dimensões do símbolo. A urgência da contradição conduz à linguagem sobrecarregada, alusiva, recorrente, descontínua e permanentemente incompleta. A cultura possui conotações severas, é omissa (portanto: completa) $^{167}$.

Dessa forma, o ponto subversivo essencial, tanto se direcionarmos o nosso olhar para o racionalismo cartesiano, quanto se o direcionarmos para as amarras da cultura (que, tal como a herdamos, se constitui na modernidade e, por isso, obedece às diretrizes racionalistas) é, nas palavras de Merleau-Ponty: “(...) que o mundo não tem coerência, ela permanece uma ideia ou um limite que de fato jamais é atingido (...)"168, e essa ausência de coerência é justamente o que possibilita a existência das contradições no discurso poético, ao mesmo tempo que o engrandece. E o filósofo continua: “(...) que a razão reconheça que seu mundo também é inacabado, não finja ter ultrapassado o que se limitou a mascarar e não tome por incontestáveis uma civilização e um conhecimento que ela tem como função mais elevada, pelo contrário, contestar" $^{\text {169 }}$. Cruzeiro Seixas, num empenho semelhante, apresenta a seguinte citação de Pascal: “O destino da razão é ver que há muitas coisas que vão mais além do que ela." ${ }^{\prime 170}$. Também Cesariny, em texto que justifica a oposição em relação ao neorealismo, obedece à mesma lógica argumentativa: "Só aos sistemas de pensamento idealista convém afixar uma realidade estável, completa, um 'real' impossível de ser concentrado, destruído ou movido pela sua própria presença" ${ }^{\text {"171 }}$. Novamente Herberto Helder se pronuncia:

Não sou moderno, eu. A ênfase sublinha por um lado o caráter extremo da poesia e por outro a sua natureza extremamente dúbia de prática destruidora e criadora, e o segredo jubilatório dessa duplicidade; sublinha também, escandalosamente, o sentido nãointelectual, supra-racional, corporal, do poder da imaginação poética para animar o universo e identificar tudo com tudo. A cultura

${ }^{167}$ Idem, p. 119.

${ }^{168}$ MERLEAU-PONTY, Maurice. Conversas - 1948. São Paulo: Martins Fontes, 2009, p. 34.

${ }^{169}$ MERLEAU-PONTY, Maurice. Conversas - 1948. São Paulo: Martins Fontes, 2009, p. 35.

${ }^{170}$ SEIXAS, Cruzeiro. "Na $1^{\mathrm{a}}$ exposição de Cruzeiro Seixas em África, do catálogo" in A Intervenção Surrealista, Lisboa: Assírio \& Alvim, 1997, p.186

${ }^{171}$ CESARINY, Mário. "Sem título" in A intervenção surrealista. Lisboa: Assírio \& Alvim, 1997, p. 87. 
moderna tornou-se incapaz de tal ênfase, pois trata-se de uma cultura alimentada pelo racionalismo, a investigação, o utilitarismo. Se se pedir à cultura moderna para considerar o espírito enfático da magia, a identificação do nosso corpo com a matéria e as formas, toda a modernidade desaba. ${ }^{172}$

O percurso interpretativo que trilhamos se refaz por completo nessa citação, unindo ponto a ponto as recusas e as dissemelhanças com o poético, este sim: júbilo, corpo, magia, matéria.

Fato relevante, ainda, é a antologia organizada por HH, Edoi Lelia Doura, de 1985, em que, dentre nomes como Gomes Leal, Camilo Pessanha, Teixeira de Pascoaes, Fernando Pessoa, Almada Negreiros, e outros tantos, estão alguns nomes do surrealismo português: Natália Correia, Mário Cesariny, Antonio Maria Lisboa, Manuel de Castro, Ernesto Sampaio, António José Forte. No prefácio, é evidente a ponte que o poeta traça entre a sua noção de poesia, eivada pela ideia de organicidade/corpo, e os poemas que nela figuram: “(...) o lugar onde a carne é comida, e ressurge, mercê da aliança da linguagem com as formas! Não se discorre. A vitalidade nominal é intrínseca, metabólica (...)"173.

A confluência entre a fillosofia de Merleau-Ponty - no que se refere às relações entre corpos, subjetividades e subversões de modos estáticos de relação com vistas a inaugurações perceptivas - e as poéticas em jogo pode ser percebida, se trouxermos a seguinte reflexão do filósofo:

Dizendo que o corpo é simbolismo (...) o corpo passa no mundo e o mundo passa no corpo: o sentir ou o prazer, porque o corpo é móvel, isto é, poder de estar alhures é desvelamento de algo. Um órgão móvel dos sentidos (o olho, a mão) já é uma linguagem porque é uma interrogação (movimento) e uma resposta (percepção como Erfüllung [Realização] de um projeto), falar e compreender. ${ }^{174}$

O corpo, tal como propõe as elaborações de Merleau-Ponty, sendo simbolismo, é, então, apropriado pela poesia como forma de aproximação entre vida - pulsão vital e escrita, de maneira que a escrita se estabelece, tanto em Herberto Helder, como nos surrealistas, na contramão das codificações culturais e, portanto, estritamente racionais.

\footnotetext{
${ }^{172}$ HELDER, Herberto. "Herberto Helder: entrevista" In: Inimigo Rumor. Rio de Janeiro, Lisboa: Cotovia, 7 Letras, Angelus Novus, nº 11, p. 190-197, 2º semestre de 2001, p. 193.

${ }^{173}$ HELDER, Herberto. (prefácio) Edoi Lelia Doura: antologia das vozes comunicantes da poesia moderna portuguesa. Lisboa: Assírio \& Alvim, 1985, p.7.

${ }^{174}$ MELEAU-PONTY, Maurice. A natureza. São Paulo: Martins Fontes, 2006, p. 341.
} 
O corpo escrito e a escrita enquanto manifestação do corpo, o papel vital, metabólico da escrita, como fica bastante evidente no seguinte trecho de Herberto Helder:

O mundo do espírito é uma organização simbólica e o seu fundamento encontra-se na matéria, no corpo. O espírito deve entender-se como apenas o tecido de alusões simbólicas do próprio corpo. A escrita realiza a circulação do símbolo no plano material; é uma simbologia corporal e também uma corpografia simbólica. $\mathrm{Na}$ escrita reside o símbolo do corpo, mas o corpo é a última e verdadeira escrita. ${ }^{175}$

Os pronunciamentos de Cesariny quanto à questão corporal, diferentemente do que ocorre em Herberto Helder, são bastante escassos, de forma que encontramos apenas uma referência direta em textos extra-poéticos: "Com o surrealismo, a poesia faz-se olhos e ouvidos, acto testemunho" ${ }^{176}$. Essa afirmação nos conduz a uma perspectiva do surrealismo que extrapola a ideia de vanguarda literária para abarcar a noção de poesia enquanto modo de vida, como dito anteriormente. Quanto à recorrência da temática corporal em sua obra, levantamos a hipótese de que se deve à negação do pensamento lógico/racional; de forma que a corporificação do discurso poético, por assim dizer, acaba sendo uma alternativa de fuga da tradição racionalista (também o discurso místico assume esse papel de contraponto entre os surrealistas, embora não seja esse o foco da nossa atenção no presente trabalho). Importa, assim, ressaltar, que os surrealistas portugueses não atentaram para a questão do corpo com maior veemência, tal como fez $\mathrm{HH}$, isto é, o corpo muito escassamente aparece justificado ou apresentado como questão relevante nos textos manifestos, entrevistas ou demais formas de pronunciamento.

O mesmo ocorre no caso de Cruzeiro Seixas, que, em seus pronunciamentos, apenas atesta a sua adesão ao Grupo Surrealista Dissidente e a assunção dos pressupostos que o regiam, sem muitas manifestações explícitas quanto à temática corporal. Pontualmente, importa evocar outra entrevista recentemente publicada, em que Cruzeiro Seixas responde ao questionamento acerca do conhecimento de António José Forte: "Essa gente toda, conheci-a em cafés (...). E era uma coisa que eu não aguentava [eles eram intelectuais e eu não], às vezes não percebia bem aquilo tudo que

\footnotetext{
${ }^{175}$ HELDER, Herberto. Photomaton \& Vox. Lisboa: Assírio \& Alvim, p. 134.

176 CESARINY, Mário "Prefácio”, in A Intervenção Surrealista, Lisboa: Assírio \& Alvim, 1997, p. 9.
} 
se passava com eles, porque as coisas estavam intrínsecas na minha carne e nos meus ossos." 177 , de forma que o que parece estar implícito, é mesmo um surrealismo encarnado, que independe de uma fidelização grupal por meio dos encontros que privilegiassem a relação entre as ideias sobre as quais assentassem o movimento, ou seja: uma adesão à materialidade do acontecimento em detrimento de volteios em torno do pensamento que o sustentaria.

Quando, ainda, questionado sobre a recorrência do corpo nas suas imagens pictóricas e poéticas, Cruzeiro Seixas é peremptório: "O corpo é o meu templo"178. Não coincidentemente, António Barahona da Fonseca também ressalta tal característica em Cruzeiro Seixas: "a obra de Cruzeiro Seixas como uma continuação do nosso corpo (...). Os desenhos de Cruzeiro Seixas imprimem-se na nossa carne, como tatuagens. Quando os olhamos demoradamente, penetram até aos ossos e aí se recortam em baixos relevos (...)"179, menção que coloca o "espectador" no centro mesmo da questão corporal, como sendo materialmente tragado e modificado pelo contato com as criações. Há, ainda, uma referência ao corpo numa carta que Cruzeiro Seixas remete em 1956 de Dongo (Angola) à Cesariny:

Querido amigo, é isto que queremos, não é? São corpos assim os que tu afoga nas águas em chamas, porque tem verdes os cabelos verdes. Eu sei - nós sabemos demais. Está escrito que os olhos devem ser como pássaros, e voar para longe quando se aproximam nossos passos (...) não é um poema teu mas um rio do teu sangue que me vem manter (...). ${ }^{180}$

Os cabelos, os olhos e o sangue aparecem aqui associados à natureza, respectivamente, mediante o verde, os pássaros e o rio, de forma que a distância que separa os dois poetas é relativizada por um procedimento de transformar aquilo que está longe (o corpo do amigo Cesariny), naquilo que está próximo (a natureza africana). Tudo está fundido: o corpo do indivíduo é, então, o corpo da natureza, a

\footnotetext{
${ }^{177}$ SEIXAS, Cruzeiro. "Entrevista” In: Revista ENTRE, Lisboa: nº 5, p.56-71, 2014, inverno de 2014, p. 59.

178 JOAQUIM, Ana Cristina. "Entrevista com Artur Cruzeiro Seixas". Revista Desassossego, Universidade de São Paulo, nº13, p.136-141, jun./2015 (p.139).

${ }^{179}$ SEIXAS, Cruzeiro. "Entrevista" In: Revista ENTRE, Lisboa: nº 5, p.56-71, 2014, inverno de 2014, p. 78.
}

${ }^{180}$ CESARINY, Mário. A Intervenção Surrealista. Lisboa: Assírio \& Alvim, 1997, pp. 77, 78. 
natureza que rodeia Cruzeiro Seixas, é o sangue/poema de Cesariny; de forma que o poema é mesmo o corpo presentificado.

Importa mencionar que o continente africano, onde tanto Herberto Helder como Cruzeiro Seixas ${ }^{181}$ passaram longas temporadas, é um símbolo bastante adequado ao surrealismo, por alguns motivos expostos na seguinte fala de Cesariny ("Palestra de Mário Cesariny com Daniel Felipe em emissão para o Ultramar - por ocasião da primeira exposição de Cruzeiro Seixas em Luanda"):

\begin{abstract}
A África é o último continente surrealista. Tudo o que antecede, combate ou ultrapassa a interpretação estreitamente racionalista do homem e dos seus modos tem a ver com um sentido surrealista da vida. A África goza do privilégio raro de não ter produzido nem o cartesianismo [grifo nosso] nem nenhum dos sistemas de pensamento e acção baseados em universos de categorias. A África conhece um mito que nós ignoramos. Julgamo-la adormecida no passado e está talvez perfazendo o futuro. ${ }^{182}$
\end{abstract}

Em entrevista recente, Cruzeiro Seixas diz sobre a sua temporada na África: "Esse tempo foi um tempo, por estar tão longe desta civilização horrível, de reinventar a vida (...) [a poesia] foi feita naquele contato espantoso com a África, em condições únicas" $" 183$, de modo que a África aparece como contraponto de uma ideia civilizacional considerara pejorativamente pelo poeta, e mais: como espaço onde vida e poesia poderiam surgir de fato como invenção.

Num artigo intitulado "Herberto Helder: o antropófago da linguagem", Paola Poma atenta para as relações que a poesia de Herberto Helder estabelece com uma ideia de África primitiva, num sentido muito parecido com aquele que faz Cesariny. Paola Poma fala da sua poesia (com especial ênfase para os poemas da série Antropofagias) a propósito de uma "Luta porque recusa qualquer tipo de domesticação" ${ }^{184}$ e, em determinado momento, a pesquisadora atenta para uma espécie de involução - que, na poesia de Herberto Helder, soa, de fato, como uma evolução às

\footnotetext{
${ }^{181}$ Num de seus "Desaforismos", Cruzeiro Seixas afirma que “... África é uma das poucas palavras que ainda hoje acorda em mim o imediato alvoroço da paixão...". (SEIXAS, Cruzeiro. Homenagem à realidade. São Paulo: Editora Escrituras, 2005, p. 133).

${ }^{182}$ Idem, p. 73.

${ }^{183}$ LETRIA, José Jorge. Cruzeiros Seixas: A liberdade livre. Diálogo com José Jorge Letria. Lisboa: Guerra \& Paz, 2014, p. 74.

184 POMA, Paola. "Herberto Helder: o antropófago da linguagem" in Anais do XII Congresso Intenacional da Abraplip, 2009, p. 944 (http://www.abraplip.org/anais2009/documentos/ mesas_tematicas/paola_poma.pdf).
} 
avessas - já que marcada pelo percurso "homem/criatura/selvagem/bárbaro - ou seja, a cultura preterida pela barbárie" ${ }^{185}$. Nesse mesmo sentido, Eurico Gonçalves afirma: “(...) Cruzeiro Seixas se lança na redescoberta de um futuro tão antigo quanto o passado (...) $)^{, 186}$, em clara referência a um aspecto temporal que subverte a linearidade imposta pela razão; rompimento de importância capitular para o entendimento dessa nova maneira de colocação, conforme sintetiza Octavio Paz:

(...) os poetas do século XX opuseram ao tempo linear do progresso e da história o tempo instantâneo do erotismo, o tempo cíclico da analogia ou o tempo oco da consciência irônica. A imagem e o humor: duas negações do tempo sucessivo da razão crítica e sua deificação do futuro. ${ }^{187}$

Nota-se, assim, uma confluência de olhares sobre a África por parte de Herberto Helder, Cruzeiro Seixas e Cesariny, que acaba por ser também uma confluência subversiva em relação aos modelos de estratificação impostos pela cultura ocidental; sem dúvida pautada por uma ideia de civilização gerida pelo pensamento racionalista, especialmente no aspecto evolutivo no qual se calça a razão: a ideia de progresso. António Cândido Franco acerta, quando afirma, no mesmo sentido:

É conhecida - e de aplaudir por inteiro - a indiferença de André Breton diante do moderno pelo moderno, como se aquilo que de verdade lhe interessasse tanto se encontrasse no passado, no presente, no futuro ou noutro tempo qualquer a inventar. ${ }^{188}$

Feito esse percurso, importa sintetizar as bases pelas quais transitamos: ocorre que a in-scrição do corpo confunde-se, no movimento mesmo da escrita, com a sua exscrição, isto é, o corpo por dentro, o corpo íntimo do eu subjetivo é conformado pelo processo criativo, e dessa exposição escritural é que ele se constitui e delimita um universo relacional dotado de verdade própria, autônoma (daí o rompimento com um referencial qualquer...). Essa verdade não é outra coisa senão a inauguração da existência do sujeito da escrita e depende, portanto, de uma coincidência e

\footnotetext{
${ }^{185}$ Idem, p. 945.

${ }^{186}$ GONÇALVES, Eurico. Cartaz da exposição de Cruzeiro Seixas na Galeria de Arte Moderna (28 de maio - 17 de junho de 1982), sehue em anexo, p. 209.

${ }^{187}$ PAZ, Octavio. Os filho do barro. Rio de Janeiro: Nova Fronteira, 1984, p. 140.

${ }^{188}$ FRANCO, António Cândido. Teixeira de Pacoaes nas palavras do surrealismo em português. Editora Licorne, 2010, p. 18.
} 
simultaneidade entre eu e outro, entre percepção e criação, entre dentro e fora, entre ato e revelação: a revelação dessa verdade não adquire formas poéticas, como poderia supor uma visada idealista - do ponto de vista filosófico - ou referencial - do ponto de vista linguístico -, mas é verdade inaugurada pela própria escrita, ela é a forma poética. Exatamente como a vida, que se confunde com seu percurso, a escrita se confunde com sua verdade: vida e escrita, portanto, sobrepostas. O operador máximo desse eixo de sobreposição é, sem dúvida, o corpo, uma vez que é tematizado pelos poetas ao mesmo tempo que se impõe, nas poéticas em questão, como único meio possível de efetivação da escrita (já que a escrita implica a mão sobre o papel no ato de movimentação das matérias). O corpo, portanto, é de fato o catalisador entre escrita e existência, e garante, assim, a verdade ontológica da escrita em Herberto Helder, em Mário Cesariny e em Cruzeiro Seixas - “A verdadeira filosofia é reaprender a ver o mundo, e nesse sentido uma história narrada pode significar o mundo com tanta profundidade quanto um tratado de filosofia" ${ }^{\prime 189}$.

\footnotetext{
${ }^{189}$ MERLEAU-PONTY. Maurice. Fenomenologia da percepção. São Paulo: Martins Fontes, 1996, p.
} 19. 
3. Capítulo II:

O corpo na elaboração do sujeito da escrita 


\subsection{Vida e obra}

O nome que lhe tinham posto era, no entanto, demasiado para uma só pessoa. Trazê-lo assim sempre consigo abria-lhe feridas pelo corpo (...) $)^{190}$

Os nomes, não os dizemos com a parte alta da cabeça, dizêmo-los com os pulmões, antes de chegarem à cabeça. O que a cabeça ordena não forma nome senão nos pulmões. ${ }^{191}$

Num livro bastante curioso pela abrangência e peculiaridade com que trata a questão do contexto literário, Dominique Maingueneau afirma: “(...) a obra participa da vida do escritor. $O$ que se deve levar em consideração não é a obra fora da vida, nem a vida fora da obra, mas sua difícil união". ${ }^{192}$ Afirma, ainda, que “(...) a obra só pode surgir se, de uma maneira ou de outra, encontrar sua efetuação numa existência" ${ }^{\prime 193}$. Olhar para as relações entre vida e obra sem buscar nelas um elo causal que vai da vida à obra, como usualmente ocorre - sendo que, nessas abordagens tão desgastadas pela tentativa de encontrar o motivo, o disparo inicial, a verdade extratextual; a vida seria a causadora da obra, isto é, teria de ser pensada numa cadeia temporal como algo que antecede a obra - é suficientemente adequado para a leitura que aqui propomos. Isso nos redime, de certa feita, de percorrer um caminho em que a árvore genealógica dos poetas fosse requisitada para justificar, por exemplo, a recorrência da mulher mãe na poesia de Herberto Helder, ou a homossexualidade presente nos versos de Cesariny e tão insistentemente camuflada nos versos de Cruzeiro Seixas. Mais do que isso, o rompimento com o elo causal entre vida e obra, nos permite pensar essa relação no eixo da simultaneidade: a obra, como bem formulou Maingueneau, se efetua na existência, é ela mesma parte do existir, decorre na vida de maneira similar como decorrem as relações amorosas, as relações de amizade ou parentais, exatamente como decorre um resfriado ou a fome de todos os dias. Nesse sentido, a vida é obra e, muito precisamente, porque nos processos todos que envolvem a feitura de uma obra, a vida não pode ser suspensa. Maingueneau é certeiro ao se

\footnotetext{
${ }^{190}$ NAVA, Luís, Miguel. Poesia Completa (1979-1994). Lisboa: Publicações Dom Quixote, 2002, p. 147.

${ }^{191}$ ARTAUD. Antonin. Heliogabalo ou o anarquista coroado (trad. Mário Cesariny). Lisboa: Assírio \& Alvim, 1991, p. 90.

${ }^{192}$ MAINGUENEAU, Dominique. O contexto da obra literária. São Paulo: Martins Fontes, 2001, p. 46.

${ }^{193}$ Idem, p. 54.
} 
reapropriar do vocábulo exaustivamente utilizado para tratar dessa relação vida e obra, de modo a ressignificá-lo:

(...) falaremos de bio/grafia, com uma barra que une e separa dois termos em relação instável (...) A existência do criador desenvolve-se em função da parte de si mesma constituída pela obra já terminada, em curso de remate ou a ser construída. Em compensação, porém, a obra alimenta-se dessa existência que ela já habita. O escritor só consegue passar para sua obra uma experiência da vida minada pelo trabalho criativo, já obsedada pela obra. Existe aí um envolvimento recíproco e paradoxal que só se resolve no movimento da criação: a vida do escritor está à sombra da escrita, mas a escrita é uma forma de vida [grifo nosso]. O escritor "vive" a partir do momento em que sua vida é dilacerada pela exigência de criar, em que o espelho já se encontra na existência que deve refletir. ${ }^{194}$

É exatamente nessa linhagem de pensamento que nos propomos pensar o sujeito da escrita. Imprescindível levar em conta o corpo como lugar em que decorre a existência, como bem formulou Jean-Luc Nancy (conforme citação que trouxemos em outro momento), e, especialmente, como entende Merleau-Ponty, para quem a percepção - na qual necessariamente está implicada os aspectos sensoriais - é eixo fundador da subjetividade.

A recorrência do corpo, na forma a partir da qual o sujeito se escreve, nos permite pensar a escrita em relação intrínseca com a existência - existência que, por sua vez, se dá a ver no corpo -, isto é, o ato da escrita permite pensar a escrita como uma das manifestações possíveis das significações biológicas, elo indissociável entre vida e obra.

Daí que considerar a metalinguagem nessa mesma intersecção me parece de suma importância para o presente objetivo: se o foco é pensar as relações entre escrita e subjetividade/existência (e a subjetividade/existência, como venho insistindo, mediante o corpo), as evidenciações da escrita enquanto procedimento convocado à cena poética, se ocupam de reforçar o elo entre vida e obra, de modo que a escrita da existência coincide com a escrita da escrita (isto é, a evidenciação metalinguística mesma), especialmente em alguns pontos que serão ressaltados na leitura dos poemas.

O que seria, entretanto, a metalinguagem? De acordo com definição corrente, “Trata-se de metalinguagem, quando a linguagem se transforma em linguagem-objeto, a procura deliberada do êxito pela utilização da linguagem - instrumento como coisa e

${ }^{194}$ Idem, pp. 46, 47. 
não como signo"195, ou, para manter a coerência lexical desta proposta que levo adiante - e já dando um salto interpretativo - seria possível dizer que trata-se de metalinguagem, quando a linguagem se transforma em linguagem-corpo. Em outras, palavras, trata-se de metalinguagem, quando a linguagem deixa de ser um mero instrumento de referência extratextual (como ocorre na linguagem comunicativa), para ser ela mesma auto referencial, no sentido de que não aponta para algo que esteja fora da formalização literária. Empenhado nas relações entre materialidade poética e conhecimento, Paul Zumthor afirma: 'Nossos 'sentidos', na significação mais corporal da palavra, a visão, a audição, não são somente as ferramentas de registro, são órgãos de conhecimento." ${ }^{196}$, e ainda:

Ora, compreender-se não será surpreender-se, na ação das próprias vísceras, dos ritmos sanguíneos, com o que em nós o contato poético coloca em balanço? Todo texto poético é, nesse sentido, performativo, na medida em que aí ouvimos, e não de maneira metafórica, aquilo que ele nos diz. Percebemos a materialidade, o peso das palavras, sua estrutura acústica e as reações que elas provocam em nossos centros nervosos. Essa percepção, ela está lá. Não se acrescenta, ela está. ${ }^{197}$

Ora, há aqui, no esboço destas linhas, a manifesta adesão a um pressuposto bastante difundido, pelo menos, desde que os estudos da linguagem foram tomados como objeto de pesquisa científica (assim autonomeada pelos linguistas), ou mesmo com a nova hermenêutica que, a respeito das elaborações literárias, fala em termos de mundo do texto, supondo, assim, uma clara demarcação discursiva que opõe a linguagem com fins comunicativos da linguagem artística (poética) ${ }^{198}$. De acordo com

195 DA SILVA, Maria Isabel. “A metalinguagem na crônica de Drummond” In: Textualidade e discursividade (GUIMARÃES, Elisa, org.). São Paulo: Universidade Presbiteriana Mackenzie, 2010, p. 19.

${ }^{196}$ ZUMTHOR, Paul. Performance, recepção, leitura. São Paulo: Cosac Naify, 2007, 79.

${ }^{197}$ Idem, p. 55.

${ }^{198}$ Importante ressaltar a visibilidade que ganham os procedimentos de criação no século XX: Clement Greenberg evidencia a metalinguagem no campo das artes plásticas, como característica especialmente evidente na arte a partir deste século: "De Giotto a Courbet, a primeira tarefa do pintor era estabelecer uma ilusão de espaço tridimensional sobre uma superfície plana. Olhava-se através dessa superfície como se olharia através de um proscênio dentro de um palco. O modernismo tornou esse palco cada vez mais raso, até que, agora, seu pano de fundo passou a coincidir com sua cortina, que agora se tornou tudo que restou ao pintor para sobre ele trabalhar. Não é tanto a distorção ou mesmo a ausência de imagens que percebemos nessa pintura sobre cortina, mas sim a eliminação daqueles direitos espaciais que as imagens costumavam possuir quando o pintor era obrigado a criar uma ilusão do mesmo tipo de espaço que aquele em que nossos corpos se movimentam (...). A pintura agora [Clement Greenberg escreve em 1954] se tornou uma entidade que pertence à mesma ordem espacial a que pertencem nossos 
essa perspectiva, a linguagem poética seria sempre, em alguma medida, metalinguística, uma vez que não se trata de um discurso referencial: o poema não fala sobre algo, mas fala algo, e este algo é o próprio poema, sua composição sintática, fonética, sua versificação e demais recursos de composição; de modo que não há paráfrase possível, já que a "forma" é tão responsável pela sua significação quando o “conteúdo". Conforme Greimas:

O efeito de sentido surge aqui como um efeito de sentidos: o significante sonoro - e gráfico, em menor proporção - entra em jogo para conjugar suas articulações com as do significado, provocando com isto uma ilusão referencial e incitando-nos a assumir como verdadeiras as proposições emitidas pelo discurso poético, cuja sacralidade fica assim fundamentada em sua materialidade. ${ }^{199}$

De acordo com o linguista, a força coercitiva do poema é tamanha (no sentido de que se torna um objeto ou corpo autônomo, dado que sua matéria-prima sonoridade, grafismo - permite que se apresente ao mundo como dotado de materialidade), que somos levados, no confronto com o poema, a admiti-lo enquanto dado do mundo, o que se justifica na medida em que o poema é o seu próprio referente: a remissão de todo poema, no limite, é o próprio poema (a linguagem sobre a linguagem). Em consonância com as palavras de Severo Sarduy: "A única coisa que a burguesia ${ }^{200}$ não suporta, o que a "tira dos eixos", é a ideia de que o pensamento possa

corpos; não é mais o veículo de um equivalente imaginado nessa ordem (...). Se o espaço pictórico chega a enganar seu olho, é através de meios óticos, e pictóricos: por meio de relações de cor e forma amplamente divorciadas de conotações descritivas, e normalmente por meio de manipulações em que a parte superior e a parte inferior, assim como a frente e o fundo, tornam-se intercambiáveis. A pintura abstrata não apenas parece oferecer um tipo de experiência mais restrita, mais física e menos imaginativa do que a pintura ilusionista, mas parece fazê-lo sem os substantivos e os verbos transitivos, por assim, dizer, da linguagem da pintura.". Greenberg atenta ainda para as futuras possibilidades de abertura pecepcional que esta modalidade metalinguística de abordagem pode gerar: "Os especialistas do futuro talvez sejam mais sensíveis do que nós às dimensões imaginativas a às sugestões da literalidade, e encontrem na concretude das relações de cor e forma mais 'interesse humano' do que nas referencias extrapictóricas da arte ilusionista de antigamente." (GREENBERG, Clement. "Abstrato, figurativo e assim por diante" In: Arte e cultura. São Paulo: Cosac Naify, 2013, pp. 162, 163).Muito embora o termo "metalinguagem" não seja utilizado pelo crítico, é exatamente disso que trata, ao mencionar os aspectos de forma e cor (como equivalentes de uma "sintaxe" e de um "vocabulário" próprios à linguagem plástica).

${ }^{199}$ GREIMAS, A. J. "Por uma teoria do discurso poético" In: Ensaios de semiótica poética. São Paulo: Cultrix, 1975, p. 12.

${ }^{200}$ Num primeiro momento, pode parecer deslocada a colocação de classe expressa no comentário de Sarduy, que, stricto sensu, seria uma crítica contra um modo de se pensar a literatura/poesia; entretanto, faz-se necessário evocar novamente a modernidade (filosoficamente entendida), como o momento em que a tomada de consciência do sujeito pensante opera uma transformação social em que a burguesia 
pensar sobre o pensamento, de que a linguagem possa falar da linguagem, de que um autor não escreva sobre algo, mas escreva algo." 201 e, mais adiante:

O que nos engana é o que constitui a suposta exterioridade da literatura - a página, os espaços em branco, o que deles emerge entre as linhas, a horizontalidade da escritura, a própria escritura, etc. Esta aparência, este desencadear-se de significantes visuais - e por meio destes (os grafos), na nossa tradição, fonéticos - e as relações que entre eles se criam nesse lugar privilegiado da relação que é o plano da página, o volume do livro, são aquilo que um preconceito persistente considerou como a face exterior, como o reverso de algo que seria o que essa face expressa: os conteúdos, ideias, mensagem, ou então uma "ficção", um mundo imaginário, etc. § Esse preconceito, manifesto ou não, edulcorado com diversos vocabulários, assumido por sucessivas dialéticas, é o do realismo. Tudo nele, em sua vasta gramática, apoiada pela cultura, garantia de sua ideologia, supõe uma realidade exterior ao texto, à literalidade da escritura. Essa realidade que o autor se limitaria a expressar, a traduzir, dirigiria os movimentos da página, seu corpo, suas linguagens, a materialidade da escritura. ${ }^{202}$

Ora, é mesmo em prol da não-referencialidade que Sarduy se manifesta nesse longo trecho supracitado; um olhar para o poema (e, mais amplamente, para a literatura) como entidade autônoma, insisto: um corpo em pleno funcionamento. Também Blanchot vai falar em termos semelhantes a respeito do modo como os surrealistas se relacionam com as palavras:

De um lado, na escrita automática, não é propriamente a palavra que se torna livre, mas a palavra e minha liberdade que se tornam uma só coisa. Penetro na palavra, ela guarda minha marca e é minha realidade impressa; adere à minha não aderência. Mas de outro lado, essa liberdade das palavras significa que as palavras se liberam por si mesmas: elas não dependem mais exclusivamente das coisas que expressam, agem por conta própria, brincam e, como diz Breton, "fazem amor". Os surrealistas perceberam muito bem - e se serviram disso admiravelmente bem - o caráter estranho das palavras: viram que tinham uma espontaneidade própria. Há muito tempo a linguagem já pretendia ter um tipo especial de existência: ela recusava a simples transparência, não era apenas um olhar, uma

surge como nova classe ascendente, e passa a ditar as regras de ordenação do mundo conforme uma lógica racionalista que irá redundar numa lógica de capitalização, ou seja: os discursos devem ser utilitários, não seria possível simplesmente dizer algo, com o desinteresse utilitário com que o poema o faz. Se a utilidade é banida do discurso poético (com o que me coloco plenamente de acordo), não é banido, entretanto, um certo propósito que, conforme os poetas em questão, pode ser subsumido no eixo da constituição subjetiva.

201 SARDUY, Severo. Escrito sobre um corpo. São Paulo, Editora perspectiva, 1979, p. 22.

${ }^{202}$ Idem, p. 48. 
maneira de ver; ela existia, era uma coisa concreta $(\ldots) .{ }^{203}$

É claro que essas reflexões comportam, ao menos, duas objeções: a primeira delas, calcada no discurso da não-referencialidade, o que me leva a modalizar a assertiva e considerar que um poema tem sempre um ponto de partida e um ponto de chegada, ou seja, vem de algum lugar (está necessariamente inserido em um determinado período histórico e é fruto de uma formalização operada por um indivíduo que, por sua vez, tem sua trajetória particular constituída por crenças, adesões teóricas éticas e estéticas, etc.), e vai para algum lugar (é recebido por uma determinada comunidade de leitores que também está inserida num momento histórico - não necessariamente coincidente com o momento em que a obra foi publicada -, e que, por sua vez, pode entrar em consonância ou dissonância com o projeto criativo que ali se apresenta); de modo que há graus reconhecíveis de referencialidade a serem identificados nos poemas, tais como menções a fatos históricos, a acontecimentos particulares ou a pessoas que de fato existiram/existem; a prática da ekphrasis, que ocorre como descrição de uma obra visual previamente existente; formas variadas de intertextualidade, etc. Tais graus de referencialidade, entretanto, não dissolvem o núcleo duro que se apresenta como poema, sua autonomia, sua maneira de se manifestar diante do mundo extratextual como um objeto ou corpo existente. A segunda objeção possível se refere à afirmação de que todo poema seria metalinguístico, já que, como decorrência de um discurso não-referencial, o poema apontaria, no limite, para si próprio enquanto linguagem criadora de mundo. A objeção, é claro, reside no fato de que, se todo poema é metalinguístico, nenhum poema é metalinguístico, ou seja, a categoria "metalinguagem" estaria destituída de poder de análise e interpretação, já que não seria capaz de particularizar este ou aquele poema. Para escapar a esta segunda objeção - que entretanto poderia ser facilmente refutada, se considerássemos que a peculiaridade de cada poema não seria devida ao fato de nele haver ou não metalinguagem, mas, diferentemente, à maneira como cada poema é capaz de atualizar a metalinguagem que lhe é inerente -, recorro a algumas reflexões acerca do tema empenhadas por Josette Rey-Debove, que se dedicou a conceituar e a explicitar as diversas manifestações possíveis de metalinguagem.

Ao se debruçar sobre as questões implicadas na delimitação do que pode ser considerado um fato metalinguístico, a pesquisadora - que inicialmente não se debruça

${ }^{203}$ BLANCHOT, Maurice. A parte do fogo. Rio de Jnaeiro: Rocco, 2011, pp. 97, 98. 
sobre o discurso poético - concebe uma distinção bastante útil para a ampliação da noção de metalinguagem: se, por um lado, há palavras que por si só desempenham função metalinguística ("Les mots métalinguistiques, dont le statut est plus clair, sont généralement perçus comme des éléments d'une terminologie spécialisée, alors que tous les termes de parole (et d'écriture) en font partie." ${ }^{204}$ ), por outro lado, há formas de utilização das palavras que podem conotá-las como metalinguísticas:

La saisie de la fonction métalinguistique se fait en discours. Mais il est aisé de constater que ces faits de discours correspondent, pour une grande part, à une codification, donc à un système en langue, ne serait-ce qu'en considérant des faits lexicaux, par exemple

e ainda: l'existence des mots vox, mot, word, palabra, wort. ${ }^{205}$

Le mot métalinguistique est ou un mot qui est destiné à parler du langage (ex. adjectif), ou un mot polysémique qui, dans un des ses sens, parle du langage (ex. articuler); tout mot neutre peut acquérir, par le contexte, une valeur métalinguistique (ex. long dans un long discours), mais ce n'est qu'un effet de sens en contexte, non un sens particulier. ${ }^{206}$

Desse modo, a compreensão de um fato metalinguístico exige, no mais das vezes, uma operação de contextualização discursiva e, no que concerne ao discurso poético em específico - foco de nosso interesse -, uma operação propriamente interpretativa. Quando se pronuncia acerca da especificidade poética, Josette ReyDebove manifesta um ponto de vista comum àquele que expus inicialmente, isto é, supõe a não-referencialidade poética como um dado metalinguístico per si e, para tanto, toma emprestada a visada de Valéry:

Dans la communication courante, le discours est transparent, le signe n'est jamais perçu en tant que tel, sauf lorsqu'il est inconnu (...). Dans le texte littéraire, et spécialement le texte poétique, où l'expression personnelle (Comme je dis) se donne libre cours, construisant son propre code, le discours s'opacifie et impose ses signes au décodeur. Cette 'conscience métalinguistique', qui est en fait une SIGNIFICATION, était pour Valéry l'essentiel de la communément poétique, comme le rappelle Alain Rey: 'C'est que le sens, communément et couramment, est une attente de sa propre mort, un sursis avant la compréhension, cette transformation de l'homme au moyen de la négation du signe [...]. Il suffit au contraire

\footnotetext{
${ }^{204}$ REY-DEBOVE, Josette. Le metalangage. Montréal: Le Robert, 1986, p. 2.

${ }^{205}$ Idem, p. 20.

${ }^{206}$ Idem, p. 29.
} 
d'une incompréhension, inquiétude, besoin..., et le langage est rappelé' (Rey, 1974, p. 42). ${ }^{207}$

No caso do texto poético, os procedimentos de seleção e combinação operados pelo ato criativo se ocupam de, mediante uma nova sintaxe - no mais das vezes, resultado do deslocamento dos vocábulos de seu uso comunicativo -, oferecer uma nova percepção sobre o mundo que nada mais é do que uma nova percepção sobre a linguagem, primeiramente elaborada pelo poeta neste ato que é mesmo uma forma de inauguração de formas perceptivas (daí a pertinência de inserir as reflexões de Merleau-Ponty nesse contexto).

Ao retomar a heterodoxa proposta de relação entre vida e obra (tal como exposta mediante Maingueneau) nesse contexto de reflexão sobre metalinguagem, temos que a vida - entendida na intersecção com o ato criativo - passa a ser conotada, no que concerne à prática poética, com um sentido de linguagem ela própria, de modo que a elaboração discursiva sobre o corpo se estabelece em relação intrínseca com a elaboração discursiva ela mesma. Tal a importância das seguintes palavras de Josette Rey-Debove: "Le langage est susceptible de parler de tout, y compris de lui-même. Cette phrase doit être entendue au sens le plus général de langage, et au sens le plus complexe de lui-même." 208 , de modo que o sentido mais geral de "linguagem", nesse contexto, seria exatamente o sentido que brota da elaboração subjetiva no discurso poético; e, em consonância com o sentido mais complexo de "ela mesma", linguagem e vida passam a ser entendidas como indissociáveis, supondo-se assim, a linguagem como fator particularizador da vida humana, sem deixar de ressaltar toda a carga ontológica de que se reveste essa afirmação, a saber: a linguagem como definidora do homem, portanto, única via possível de (re)constituição subjetiva mediante as metamorfoses perceptivas que é capaz de operar. Conforme elaborou, Jean-Luc Nancy: "Porquê e como uma ou várias diferença(s) dos 'sentidos' em geral, e entre os sentidos sensíveis [sens sensibles] e o sentido sensato [sens sensé]?"209

\footnotetext{
${ }^{207}$ Idem, p. 288.

${ }^{208}$ Idem, p. 75.

${ }^{209}$ NANCY, Jean-Luc. À escuta. Belo Horizonte: Edições Chão da Feira, 2014, p. 13.
} 


\subsection{Herberto Helder e o nome-artesanato}

A seleção dos poemas, como dito inicialmente, obedece ao recorte temático e, para este segundo capítulo, elegemos poemas dos três autores em que o nome se apresenta como eixo de intersecção entre subjetividade e metalinguagem. A começar por Herberto Helder, segue a leitura do poema "Sou eu, assimétrico, artesão, anterior" ${ }^{210}$, em Do mundo, primeiramente publicado em 1994. Aqui o reproduzimos a partir de Ofício Cantante, de 2009, penúltimo volume de reunião de seus poemas ${ }^{211}$. Segue:

Sou eu, assimétrico, artesão, anterior

- na infância, no inferno.

Desarrumado num retrato em outro todo aberto.

A luz apoia-se nos planos de ar e água sobrepostos,

e entre eles desenvolvem-se

as matérias.

Trabalho um nome, o meu nome, a dor do sangue,

defronte

da massa inóspita ou da massa

mansa de outros nomes.

Vinhos enxameados, copos, facas, frutos opacos, leves

nomes,

escrevem-nos os dedos ferozes no papel

pouco, próximo. Tudo se purifica: o mundo

e o seu vocabulário. No retrato e no rosto, nas idades em que,

gramatical, carnalmente, me reparto.

Desequilibro-me para o lado onde trabalha a morte.

O lado em como isto se cala.

O primeiro verso inicia-se pelo pronome "eu", pronome dêitico que, de algum

\footnotetext{
${ }^{210}$ HELDER, Herberto. Oficio Cantante. Lisboa: Assírio \& Alvim, 2009, pp. 523, 524.

${ }^{211}$ Este volume não comporta seus dois últimos livros - Servidões, de 2013 e A morte sem mestre, de 2014, tampouco Poemas canhotos (póstumo de 2015), os dois primeiros foram incluídos, entretanto, na última publicação de sua obra: Poemas completos, de 2014.
} 
modo, obedece à mesma lógica de atuação do substantivo nome que lemos no sétimo verso, uma vez que ambos ("eu" e "nome") são termos que podem ser apropriados por todo e qualquer sujeito do discurso para designar a si mesmo. A apresentação deste “eu” é mesmo imediata: "Sou eu”, afirma o sujeito da enunciação, já no primeiro verso e, a seguir, entre vírgulas, uma série de epítetos que o qualificam como assimétrico, como artesão, como anterior. Voltaremos aos qualificativos em breve. Quanto ao nome, substantivo acompanhado pelo pronome possessivo (“o meu nome”), é enunciado apenas mediante o seu "denominador comum", isto é, de acordo com a gramática, o substantivo comum, nome. O seu correlato particularizador, o nome próprio a partir do qual cada ser se individualiza não é, entretanto, enunciado; em outras palavras, a assinatura, palavra e grafia de caráter particular que não se encontra dicionarizada - pois que seria necessária uma biografia, a história de uma vida para expressar o sentido que cada nome carrega -, a assinatura, então, permanece incógnita: o sujeito aqui se apresenta pela metalinguagem gramatical que parece defini-lo. Valeria perguntar, o ser se constitui pela linguagem? Sim, ao que parece. Daí a pertinência de pensar a percepção, conforme Merleu-Ponty, enquanto constituinte subjetiva, ressalto: a linguagem como meio de reelaboração perceptiva, neste caso, incidindo sobre a subjetividade mesma.

Vale atentar, no entanto, para o fato de que se trata de uma linguagem encarnada, linguagem por onde corre o sangue (indício de vida, indício necessário: o sangue em movimento. Se não há sangue, não há vida, de modo que a presença do sangue serve para qualificar esta escrita como vital). E o sangue, por sua vez, só por meio da dor é que pode ser visto, "a dor do sangue", como lemos no mesmo sétimo verso em que está o "nome" (o que faz da associação entre um e outro termo, inevitável), ou seja, só mediante uma fissura, só mediante um rasgo na pele o sangue poderia vir à superfície e dar-se a ver, como de fato ocorre: é como se o sangue se situasse na superfície mesma do poema ao ser verbalizado, a imagem poética se presentifica. Isto significa que, para que o sangue rompa com o espaço interior a que está circunscrito, para que saia de sua intimidade de nome e se deixe entrever no espaço do poema, é preciso que haja uma ferida, daí a dor como consequência da exposição que a palavra atualiza, sendo poema.

Há ainda que mencionar outra possível interpretação para a associação que evidenciamos entre nome e sangue: ambos são heranças familiares, ambos são elos que identificam o sujeito a um meio previamente determinado, a um meio que, portanto, 
não é fruto da escolha por afinidade e, nesse sentido, lemos juntamente com a "dor do sangue", também a imagem do retrato em que este "eu" aparece "desarrumado", numa possível menção à inadequação às heranças instituídas ou, ainda, um atestado de que o reconhecimento de si se faz no confronto com a alteridade codificada. Mais uma vez, a percepção expressa corporalmente se apresenta na imagem que o sujeito poético faz de si e de sua facticidade (o ser em situação a partir dos desvios operados pelo retrato fixado com certa indeterminação; fixado por outro, certamente, embora o outro não se apresente na cena relatada): há lucidez nesse modo de perceber-se, um passo dado para reconstituir-se pela escrita, conforme o decorrer do poema.

Ora, importa retomar a tripla qualificação do "eu” ("assimétrico, artesão, anterior”) - a qual remetemos há pouco - que diz, de alguma forma, do espaço, da ação e do tempo.

Do espaço, sabemos que é irregular, desigual - e essa desigualdade parece recair sobre o próprio sujeito, de modo que este "eu" (assimétrico) não é igual a si mesmo, não são iguais sequer os termos da comparação: "Desarrumado num retrato em outro todo aberto.”. Ora, há subversão nos modos de estabelecer as polaridades, apenas neste contexto é que desarrumado se opõe, não a arrumado, como seria de se supor, mas à aberto (que, por sua vez, opor-se-ia a fechado, num modo de oposição habitual). Tais construções reiteram a desigualdade a partir da qual o "eu" se apresenta e, mais do que isso, dão forma disforme a este "eu" (se é que é possível o paradoxo como tentativa de explicação...), situam o espaço que o delimita - embora o retrato em que o sujeito se apresenta "aberto" é como se o víssemos sem molduras, numa possível alusão ao ilimitado -, ao mesmo tempo que o "desarrumam".

Merece especial atenção o fato de que o "eu" se apresenta "aberto" num dos retratos e essa abertura, se associada ao caráter corpóreo no qual tanto insistimos, permite pensar um transito de dentro para fora e de fora para dentro, uma relação do corpo por dentro com o corpo, os corpos, os objetos por fora - fato que relacionamos à ideia de exposição mediante o poema, tanto quanto o seria dar a ver o sangue pela dor. Novamente Merleau-Ponty, e o seu conceito de carne relacional: "Essa coisa-abertura para as coisas, participáveis por elas, ou que as porta em seu circuito, é propriamente $a$ carne.",212

Da $a c ̧ a \tilde{o}$, o artesanato: atividade fruto do empenho individual, intrinsecamente

${ }^{212}$ MELEAU-PONTY, Maurice. A natureza. São Paulo: Martins Fontes, 2006, p. 359. 
associada ao trabalho manual. Este "eu" se apresenta, assim, como alguém que esculpe a sintaxe do poema, como aquele que pode tocar nas palavras, situado entre os dois elementos do mundo externo - "ar e água sobrepostos", em que a sobreposição pode indicar mistura e, sendo assim, este "eu" se situa na mistura mesma, local onde a luz encontra apoio e, portanto, confirma a positividade, isto é, ilumina, por assim dizer, a ideia de desarrumação e a ideia de abertura. Da desarrumação e da abertura dizemos que, se em algum momento figuraram como opostas, figuram agora como cúmplices de um mesmo eixo de abrangência: "eu", "água" e "ar" compondo o corpo no/do poema (atentando para o fato de que tanto a água quanto o ar são elementos vitais, isto é, sem qualquer um deles, a vida humana, o funcionamento do corpo não seria possível), ele permite que a via de comunicação entre o que está fora e o que está dentro, se estabeleça mediante o seu labor, a sua atividade manual - sem esquecer que a mão é o membro que empunha a caneta possibilitando a mediação entre o corpo do sujeito e o corpo do poema - estes dois corpos que na ação artesanal acabam por fundir-se. “(...) entre eles [ar e água, os elementos vitais]/ desenvolvem-se/ as matérias.", de modo que, considerando o poema ele mesmo como um corpo - e, portanto, autônomo -, poderíamos supor que, para além do labor do sujeito/artesão, há este labor que se manifesta independentemente da vontade do sujeito, isso que é o desenvolvimento das matérias (como se as próprias matérias fossem, em alguma medida, causa e efeito da sua atividade).

Quanto ao labor empreendido pelo sujeito da escrita, a ênfase recai sobre a escrita do nome próprio: "Trabalho um nome, o meu nome, a dor do sangue,/ defronte/da massa inóspita ou da massa/ mansa de outros nomes.”. O nome que lhe é próprio (no sentido de que vem acompanhado pelo pronome possessivo) aparece, então, diante de outros nomes: nomes massivos ("massa mansa"), encarnados como o nome do sujeito da escrita, são entretanto, inóspitos, no sentido de que não se chega a alcançar o "outro" como possível lar, o outro é corpo que não pode ser habitado. São mansos, afirma o sujeito, percebendo, pelo contraste do qualificativo (sugerimos a mansidão, como o que não reverbera incisivamente no sujeito) o lugar que habita, a massa própria, o limite que implica o seu corpo, ou seja, limite do "eu" é a dor (consequente, como propusemos, deste que também é um labor: a fissura, a ferida, o fazer ver o sangue ${ }^{213}$ ), pois a dor, assim como o gozo, só pode ser sentida no corpo

${ }^{213}$ Vale aqui um parênteses para trazer um trecho de Apresentação do Rosto, em que o sangue é o elo 
próprio; enquanto o corpo alheio jaz massa mansa, sendo, dessa forma, percepção sutil do artesão que se esculpe a si mesmo no corpo do poema. Daí a abertura, que poderíamos ler, também ela, sob o prisma da assimetria: por um lado há possibilidade de trânsito entre "eu" e "outro", mas apenas por um lado, isto é, apenas mansamente ou parcialmente o outro é percebido (aqui, vale relembrar a reflexão de Merleau-Ponty segundo a qual o corpo próprio se estabelece e, portanto é percebido, de modo diverso do corpo do outro).

Do tempo, poderíamos dizer que a predominância da forma verbal no presente, é complexificada mediante as referências a outros tempos e conjuga isso que aqui nomeamos memória do futuro (para tomar emprestado o sentido atribuído por Marcelo Tápia $^{214}$ à simultaneidade entre passado e futuro que aqui flagramos: ocorrência que se dá no presente, momento mesmo da escrita do poema que se reatualiza a cada nova leitura).

Haveria, desse modo, uma coincidência perceptiva deste "eu" "anterior" com a morte, tempo futuro, que apenas como silêncio pode ser evocada: "Desequilibro-me para o lado onde trabalha a morte./ O lado em como isto se cala.”. Ora, este lado, um dos tantos (sem especificação quantitativa) nos quais existe este sujeito assimétrico, temporalmente assimétrico como atestam a repartição indicada nos seguintes versos:

significativo na percepção que esse sujeito vai elaborando acerca de si mesmo: "Em mim, uma alegria tão forte que se torna necessário fazer qualquer coisa. Tiro do bolso o meu pequeno canivete e, no braço nu, traço um golpe fundo. Vejo o sangue correr, o meu sangue." (HELDER, Herberto. Apresentação do rosto. Lisboa: Ed. Ulisseia, 1968, p. 46). Esse contato com a própria intimidade (a possibilidade de ver o corpo que se expõe, que transita de dentro para fora), a possibilidade do autoconhecimento, a percepção de si é, no entanto, mediado por outro "evento sangrento", por assim dizer; desta vez, envolvendo a presença da alteridade: "Comigo foi assim, pensa ele: golpeei o braço, expus-me, criança doce e dramática em frente do espanto e da comoção das mulheres, caí no abismo, ressuscitei sob a delicadíssima atenção feminina, cresceram-me os braços e as pernas, insinuou-se em mim um novo ritmo, soube que ultrapassei um perigo e fiquei de uma outra maneira diante de tudo (...). Depois diz: aconteceu-lhe o mesmo a ela, mas de um modo particular (...). Quanto ao sangue de uma irmã de doze anos que de repente pára de comer ameixas e olha a parede e fica em pânico e grita e atrai as mulheres e é arrastada para o fundo da casa - começo a saber uma pequena coisa. Tenho medo." (Idem, p.60). Se dissemos, na leitura do poema, que o corpo do outro, massa mansa, é parcialmente inacessível no sentido de não ser capaz de provocar dor ou prazer, ocorre, em Apresentação do rosto, mediante este episódio da menstruação da irmã, uma complexificação da relação com a alteridade: a percepção deste sujeito que se situa do lado de fora do mundo feminino, é composta também por aquilo que lhe é velado. Dessa obscuridade, entretanto, vem também um conhecimento mediado pelo medo: "começo a saber uma pequena coisa. Tenho medo.”. Novamente o corpo da percepção está em evidência, seja ele o corpo próprio que percebe a si mesmo ou o corpo que percebe que há o imperceptível (conhecimento adquirido pela via negativa, a percepção de que não há percepção possível referente ao corpo alheio...).

${ }^{214}$ Eis o poema, "EU”, em que flagramos tal sentido: "o telefone tocou,/e não era ninguém/ o que podia ter sido,/ qualquer voz antiga/ ou voz anônima,/ desconhecida,/ abriu-me todos/ os ecos da memória,/ para trás e/ para frente,/ para o passado/ e para o futuro/ o presente vazio,/ ausente de voz,/ cheio de tudo que não ouvi,/ cheio de todas as chances,/ aturdiu-me:/ um silêncio eufórico/ com todas as vozes/ faltantes" (TÁPIA, Marcelo. Valor de uso. São Paulo: [e] editorial, 2009, p. 57). 
"No retrato e no rosto, nas idades em que, gramatical, carnalmente, me reparto." - este lado, dizíamos, implica o silêncio como é evidente no fim do poema e, no entanto, somos diretamente lançados para a o primeiro verso em que a assimetria de partida, justifica essa espécie de circularidade, pois no início, há o vocábulo "assimétrico" e no fim, a evidenciação de um dos lados dessa assimetria, de forma que "lado onde trabalha a morte" não esgota as possíveis referências da assimetria, induzindo-nos a retornar ao verso inicial, ou seja, o silêncio é novamente e sempre desfeito pelo princípio ao qual eternamente retorna.

Sobre a repartição gramatical, carnal deste "eu", vale atentar para o modo como, no contexto do poema, gramática e carne são apresentados numa relação de sinonímia, o que reafirma a feitura do poema como forma de percepção da existência, e a relação vida e obra se fortalece no sentido em que expusemos mediante as considerações de Maingueneau. O próprio Herberto Helder se pronuncia a este respeito: "Fazem uma vida com boa caligrafia, eles [os poetas] - e acabou-se.",215, e, em texto ainda mais antigo sobre a poesia de Afonso Duarte: "A poesia é que é importante, exatamente porque é a própria vida do poeta, a qual nem a proximidade da morte pode embaraçar." ${ }^{216}$, associando, de maneira radical, vida e linguagem/ofício poético - ofício artesanal este, decorrência do uso das mãos ao tocarem as matérias vocabulares.

"O mundo e seu vocabulário", as coisas do mundo, os objetos nos quais se pode tocar a partir do corpo. A exemplo do poeta: as palavras/corpos/objetos "vinhos enxameados", "copos", "facas", "frutos opacos", são todos "leves nomes", assim qualificados na suposição de que há leveza nessa matéria que se vai buscar ao mundo, não pesam sobre as mãos, sempre que transformadas as matérias em matéria verbal, vocábulos, corpos da escrita. Da leveza, certamente se diz por causa da purificação

\footnotetext{
${ }^{215}$ HELDER, Herberto. Apresentação do rosto. Lisboa: Ed. Ulisseia, 1968, p. 164. Mais recentemente, em texto que abre seu penúltimo livro de poemas, Servidões, Herberto Helder complexifica essa relação entre vida e escrita nos seguintes termos: “( ...) creio haver quem nasça de si próprio e significa talvez, isto, que nada tenho a ver com a história, que a criei, eu, à história, passe a megalomania se o é; a história é a minha biografia e os pontos onde vida e criação tocam pontos da história comum, pensandose que há história comum, são contactos de que me sirvo não para a ficção da minha existência, mas para a ficção da história que serve a verdade biográfica." (HELDER, Herberto. Servidões. Lisboa: Assírio \& Alvim, 2013, pp. 17, 18.). Há, nesse pequeno trecho, a inserção de um terceiro elemento situado entre a vida e a obra: trata-se da história comum e, em que pesem as desconfianças que o autor nutre diante desse universo socialmente partilhado, esse elemento será de grande importância para o próximo capítulo, quando nos ativermos às reflexões acerca das relações entre corpos.
}

${ }^{216}$ HELDER, Herberto. "Relance sobre Afonso Duarte". In: Folhas de poesia. Lisboa no 3, p.4-6, setembro de 1958 , p. 6. 
operada pelos dedos (ferozes) no ato da escrita: "escrevem-nos os dedos ferozes no papel/ pouco, próximo.”, e mais do que a leveza, há que se atentar para a proximidade, signo de um contato possível com a matéria exterior, sem, no entanto, deixar de marcar uma separação. O papel é pouco, em contraste com a ferocidade dos dedos, e a ferocidade dos dedos, por sua vez, contrasta com a leveza dos nomes: daí a assimetria que, além de abarcar o fluxo temporal, as várias idades/metamorfoses da carne e da gramática (sempre em comunhão, nunca é demais ressaltar), abarca ainda o contato deste sujeito com o mundo.

Assimetria maior, ao que me parece, é esta mesma que decorre dos vários tempos, a tentativa de fixar pela matéria da palavra uma existência em constante transformação e que, no limite, redunda na diferenciação entre vida e morte no espaço da escrita: a vida como ofício da carne diante da carne do verbo, a morte, como o desequilíbrio, pendor para a impossibilidade perceptiva: "O lado em como isto se cala". O sujeito calado, diríamos, é justamente aquele que se coloca diante dos limites da percepção, uma vez que aquilo que não pode ser percebido acerca de si, não pode tampouco tomar forma na matéria da escrita.

Sobre este ciclo vida/morte, a que aludimos há pouco, vale trazer as palavras de Silvina Rodrigues Lopes:

[Herberto Helder] põe em jogo a vida como potência que traz em si
outra morte - aquela que não é apenas a terrível negação do
indivíduo na linguagem que recebe: a outra morte, dionisíaca, que é
também a outra vida que cada corpo segrega ao participar do instante
da criação onde a forma e o informe, as trevas e a luz, se reúnem. O
sublime é da ordem dessa queda que põe em movimento a linguagem
e eleva à dança. ${ }^{217}$

Ora, importa enfatizar, nas palavras da ensaísta, esse jogo entre vida e morte sobre o tabuleiro da escrita (espaço em que a vida acontece), isto é, no ato da criação os opostos se assimilam, encontram uma maneira de convergência, de modo que a outra morte repercute na outra vida e isso se dá no corpo mesmo da existência, com como bem sublinhou Silvina. Sobre o dionisíaco, a luz, o sublime e a dança que essa morte abarca - enquanto participante do movimento vital - poderíamos dizer que tomam para si a tarefa de estabelecer o vínculo que pressupõe a circularidade

\footnotetext{
${ }^{217}$ LOPES, Silvina Rodrigues. A inocência do devir: ensaio a partir da obra de Herberto Helder. Viseu: Edições Vendaval, 2003, p. 31.
} 
vida/morte. Essa pulsão vital diante da morte, esse movimento circular que já havíamos flagrado na leitura do poema (com especial ênfase para o fato de que há movimento, e a percepção, portanto, é resultado desse golpe difuso sempre a modificarse, como se a forma fosse captada num contínuo de instantes que se confundem e ecoam sucessivos e remissivos, impedindo a fixação, a delimitação peremptória que uma visada racionalista teria como meta num sistema de categorias estanques), percebe-se pela contaminação que a vizinhança vocabular opera sobre o signo do silêncio, promovendo mais e mais continuidades. Em outro momento, o próprio Herberto Helder nos oferece a circularidade como chave de leitura de sua obra: "Tratase de 'escrita circular', naquele âmbito em que se concebe a volta ao ponto de partida" ${ }^{218}$. Essa circularidade, entretanto, nem sempre se faz evidente: a partir de $A$ faca não corta o fogo, a morte aparece com mais frequência e, de algum modo, ainda mantém-se como parte das percepções em que a existência decorre, permanecendo, assim, nesse ciclo vital na qual se inseria até então, embora já se faça sentir algum estremecimento deste percurso circular. Lemos no primeiro verso de um poema sem título: "a morte está tão atenta à tua força contra ela" ${ }^{219}$, e alguns versos depois, temos que essa força toma forma corpórea, é uma resistência em que somente o corpo se pode empenhar: "há muito já alguém pediu o mesmo,/ que ela recuasse,/ ilhargas, ombros, dedos, o movimento dos cabelos,/ o corpo solitário,/ um canto último fundido ao início do canto,/ mas a morte sabe que não há razão nunca,/ e quem pede sabe que não pode". Ora, o pedido de recuo diante da morte, nada mais é do que a imposição do corpo enquanto vida, o desejo manifesto de eternamente rodar nesse círculo cantante ("um canto último fundido ao início do canto", exatamente como o princípio norteador de leitura do poema anterior); mas tal pedido, isto é, a própria manifestação da existência, é vã: nada pode. Nota-se aqui que a morte vai tornando-se retilínea, um caminho numa única direção, se esboça já em oposição ao modo circular em que aparecia até então. A conjunção com a vida, vai se tornando cada vez mais turva. Também Luis Maffei ressalta essa temática, ao tratar do poema "li algures que os gregos antigos não escreviam necrológios, / (...)", em A faca não corta o fogo:

(...) é preciso passar pela morte quando se lê Herberto Helder, e há aspectos que fazem esse tema se ainda mais notável no último Herberto Helder, por algumas razões e evidências. Nenhuma delas,

\footnotetext{
${ }^{218}$ HELDER, Helberto. Photomaton \& Vox. Lisboa: Assírio \& Alvim, 2006, p. 65.

${ }^{219}$ HELDER, Helberto. Oficio Cantante. Lisboa: Assírio \& Alvim, 2009, p. 610.
} 
obviamente, é necrológica, pois à poesia não interessa o obituário, e, à herbertiana, pouco importa o logos feito mera razão. ${ }^{220}$

De modo que a leitura do crítico parece confluir com a leitura que propusemos da morte enquanto parte da vida, uma vez que ele nega a mortificação da escrita, ao negar os necrológios em favor da paixão (e no comentário, também a razão é preterida em favor da paixão).

É em Servidões, entretanto, que se nota com mais veemência que o sujeito da escrita perde o fôlego das andanças circulares. Os poemas, na sua maioria, muito breves, em contraste com a prolixidade vital por meio da qual se apresentavam em livros anteriores, são quase um atestado do pouco de ar que ainda resta a este sujeito da escrita. E o ar, como dissemos, há poucas linhas atrás, é um dos elementos sem os quais a vida se torna inviável... Lemos o seguinte verso: “(...) escrevi o poema cada vez mais curto para chegar mais depressa,"221, donde se supõe que há um ponto de chegada; e, no mesmo poema, "escrevi-o tão directo que não fosse entendido, (...)/ nem no sítio do umbigo que se liga ao sangue impuro,/ nem no sítio da boca onde se nomeia o sopro", e daí concluímos que este lugar de chegada, não é senão a morte, que, embora não seja nomeada no presente poema, é exaustivamente mencionada nos demais poemas do livro: apenas a morte pode provocar esse desentendimento carnal, apenas a morte pode figurar como o duplo velado do eixo central da vida (o umbigo, signo da nascença). A morte é, assim, palavra que a boca cala, pois que impossibilita o sopro, a circulação do ar: a morte não fala, não respira, não escreve, ou melhor, a morte escreve muito brevemente aquilo que o corpo não entende. ${ }^{222}$

Sem nunca perder de vista o corpo enquanto fundamento do sujeito da escrita, e aproveitando a deixa que a "boca" nos possibilita, enquanto parte do corpo responsável por funções vitais como a alimentação e a respiração (e, por que não estender para a fala a noção de função vital?), trazemos ainda este poema de Flash, livro de 1980, cuja

\footnotetext{
${ }^{220}$ MAFFEI, Luis. "Os gregos antigos não escreviam necrológios” In: Soldado aos laços das constelações. São Paulo: Lumme Editor, 2011, p.78.

${ }^{221}$ HELDER, Herberto. Servidões. Lisboa: Assírio \& Alvim, 2013, p. 49.

${ }^{222}$ Paul Zumthor vai mencionar o silêncio como eixo significativo para a poesia na intersecção corpórea: “A voz repousa no silêncio do corpo. Ela emana dele, depois volta. Mas o silêncio pode ser duplo; ele é ambíguo: absoluto, é um nada; integrado ao jogo da voz, torna-se significante: não necessariamente tanto como signo, mas entra no processo da significância. Nesse lugar em que a voz se dobra nela mesma, identifica-se com o sopro, de onde tantos outros simbolismos, recolhidos pelas religiões: o sopro criador , animus, rouah; a voz como poder de verdade. (ZUMTHOR, Paul. Performance, recepção, leitura. São Paulo: Cosac Naify, 2007, p. 82).
} 
nossa reprodução faz-se a partir de Oficio Cantante $^{223}$ :

Boca.

Brûlure, blessure. Onde

Desembocam, como se diz em nome, os canais muitos.

Pura consumpção em voz alta, ou num murmúrio,

entre sangue venoso, ou

traça de lume. Gangrena,

músico,

uma bolha.

Arte medonha da paixão.

Um poro monstruoso que respira o mundo.

Nele se coroam

o escuro, o fôlego, o ar ardido.

O ouro, o ouro.

Tubo sonoro por onde se coa o corpo.

Se escoa todo.

Há um deslocamento logo de partida: na sequência de um primeiro verso muito sucinto desenhado pelo vocábulo que será motor do desenvolvimento de todo o restante do poema - "Boca" -, somos conduzidos ao segundo verso, também sucinto (embora mais de um vocábulo o componha), em que o deslocamento ao qual aludimos, pode ser lido como um deslocamento espacial: muda-se de verso, muda-se de idioma e por consequência muda-se de território. Brûlure, conforme o dicionário francês $L e$ Robert, tem as seguintes acepções: "1. Lésion produite sur une partie du corps par l'action du feu, de la chaleur, d'un rayonnement ou d'une substance corrosive. Se faire une brûlure à la main. La profondeur, l'étendue d'une brûlure. Brûlures du premier $(\rightarrow$ érythème), du deuxième ( $\rightarrow$ phlyctène), du troisième degré $(\rightarrow 1$. escarre). "une brûlure enflait sa cloque d'eau » (Colette). Tache ou trou à l'endroit où un objet, une matière a brûlé. Brûlure de cigarette sur une moquette. 2. Sensation de chaleur intense, d'irritation dans l'organisme. "une brûlure lui tordait la poitrine» (Daudet). Brûlures d'estomac. 3. Altération des végétaux due au soleil ou à la gelée". No dicionário Domingos Azevedo (francês-português), lemos: "queimadura, queimadela; e

${ }^{223}$ HELDER, Helberto. Oficio Cantante. Lisboa: Assírio \& Alvim, 2009, p. 353. 
(fig.) remédio, recurso contra inconvenientes e males", de modo que uma nova acepção nos faz atentar para a ambiguidade presente no vocábulo. Ora, se lemos a boca como uma espécie de ferida provocada pelo fogo (conotação negativa), lemos também como lugar de irradiação da luz e do calor (conotação positiva), o que permite supor, novamente na esteira do poema anterior - em que o sangue, para que se fizesse ver, pressupunha uma ferida - que a luz e o calor que advém dessa boca em exposição seriam decorrência de uma fissura, um rasgo, uma ferida. A ambivalência do termo permite que o relacionemos à noção grega de pharmakon que abarca em si tanto a causa da dor quanto a cura para a dor, sendo, a um só tempo, o veneno e o remédio ${ }^{224}$.

Em "blessure" temos, segundo o Le Robert: "1. Lésion faite aux tissus vivants par une cause extérieure (pression, instrument tranchant ou contondant, arme à feu; chaleur), involontairement ou pour nuire. Types de blessures : lésion, plaie, trauma; balafre, coupure, écorchure, égratignure, entaille, éraflure, estafilade, estocade, morsure, mutilation, piqûre; bleu, bosse, brûlure, commotion, contusion, distension, ecchymose, élongation, entorse, fêlure, foulure, fracture, froissement, hématome, luxation, meurtrissure. Blessure grave, mortelle. Infliger une blessure à qqn. Etre couvert de blessures. Soigner, panser une blessure. Marque, trace d'une blessure. $\rightarrow$ cicatrice. Blessure en séton*. Condamné pour coups et blessures. Blessures involontaires. 2. Atteinte morale. $\rightarrow$ coup, douleur, froissement, offense. Blessure d'amour-propre. $\rightarrow$ humiliation. Rouvrir, raviver une blessure.". Vemos, portanto, reiterado o sentido primeiro de "brûlure", em Domingos de Azevedo, as acepções se confirmam: "Ferida, golpe, chaga", e no sentido figurado: "ferida, ofensa, injúria, insulto (tudo que ofende o espírito, a inteligência, a honra)" e, ainda, "mortificação, tormento, dor" , de modo que somos levados a considerar a própria anatomia da boca, a sua abertura como uma ferida, um corte, uma fenda que se abre para o interior do corpo e, ao mostrar a interioridade, mostra, figurativamente - já que é de subjetividade

\footnotetext{
${ }^{224}$ Essa ambiguidade está presente no mundo grego também na imagem de Dionisio, conforme o estudioso Jaa Torrano atesta na seguinte passagem: “À ambiguidade da loucura dionisíaca, benéfica ou maléfica segundo a atitude do homem perante o Deus, corresponde a ambiguidade das drogas (pharmákois, EURÍPEDES - Bacas, v. 326) com que se têm medicações e com que entretanto se adoece." (TORRANO, Jaa. O pensamento mítico no horizonte de Platão. São Paulo: Annablume Clássica, 2013, p. 15). A ambiguidade na imagem de Dionisio remete ao comentário de Silvina que expusemos em linhas anteriores para tratar da circularidade vida e morte, uma vez que ela associa a morte a um aspecto dionisíaco, de modo que a ideia da morte como sendo simplesmente uma negação da vida é, no entanto, complexificada no mesmo sentido da ambivalência presente em pharmakon. Vida e morte, cura e doença: é como se a combinação pareada entre estes quatro vocábulos pudesse totalizar os modos de manifestação da união dos opostos, gerando, cada par, um terceiro eixo de compreensão que o poema comporta.
} 
que se trata -, também a intimidade. Essa exposição é como se redundasse numa ofensa, num insulto mesmo, e o dizemos em consonância aos sentidos todos que o vocábulo comporta, mas dizemos também, tendo em vista uma ideia bastante recorrente em Herberto Helder da escrita como um ato violento ou criminoso: "O amor e a palavra são crimes sem perdão (...) a única graça concedida ao criminoso é o seu próprio crime (...). Escrever é perigoso."225, ou: “É sempre tempo de rebentar, sempre ódio, sempre crime (...)"226, e ainda, no pequeno excerto intitulado "(action-writing)": "Desejaria que este escrito fosse um puro teorema poético da violência"227

Retomando os dois primeiros versos, há uma razão propriamente fonética para a qual não podemos deixar de atentar: os dois vocábulos franceses se iniciam com o fonema /b/, assim como ocorre com "Boca" e desse deslocamento espacial que dissemos haver entre os versos e os idiomas, podemos dizer que é, de algum modo, uma aproximação: mudar de lugar (muda-se simultaneamente de verso e de idioma) para tornar mais próximos os sentidos implicados nos vocábulos envolvidos pela boca, e isso ocorre tanto porque a boca é, no corpo, aquela que pode pronunciá-los - daí que a sonoridade explosiva implicada pelo fonema inicial ser colocada em relevo - mas também porque o vocábulo "boca" é uma espécie de disparador semântico que acaba por envolver os termos franceses que lhe servem de epíteto.

Curioso tomar este poema, em que há uma manifesta ausência do "eu", como mote de leitura para pensar a subjetividade. A ausência do pronome em primeira pessoa poderia significar um sujeito que se esconde, e de alguma maneira poderíamos supôlo, mas somente se relacionarmos a subjetividade à explicitação do "eu" no poema. O pronome em primeira pessoa é aqui substituído por aquilo que seria um de seus referentes mais imediatos, ou a sua metonímia, se considerarmos a metalinguagem envolvida nesta composição. Explico: a boca como atualização do referente para o qual apontaria este "eu", dêitico que, tal como é colocado em suspenção na situação de enunciação do poema, acaba por enfatizar o teor metalinguístico dessa subjetividade por meio da imagem da boca. Poderíamos assim parafrasear: "eu, esta boca que falo" ou "boca que sou, palavra que escrevo", numa linha de leitura que guarda algumas semelhanças com aquela apresentada por Eliane Robert Moares, em $O$ corpo

\footnotetext{
${ }^{225}$ HELDER, Herberto. Photomaton \& Vox. Lisboa: Assírio \& Alvim, 2006, p. 32.

${ }^{226}$ Idem, p. 38.

${ }^{227}$ Idem, p. 80.
} 
Impossivel, conforme lemos a seguir: “(...) a consciência de si é dispersada em proveito de uma experiência autônoma da mão que escreve, o que também guarda semelhanças com a conhecida expressão de Tzara, 'o pensamento se produz na boca",228, e ainda: “As ideias deveriam ser testadas na carne; mas não só isso: a mão, a boca, os olhos, os ouvidos, o sexo eram considerados "órgãos pensantes", e qualquer pensamento que deixasse de levar isso em conta estaria confinado aos limites do idealismo." 229 .

No caso do poema de Herberto Helder, o sujeito, muito diversamente de esconder-se, dá-se a ver por este órgão vital (como já dissemos, por onde transitam o ar e o alimento) que, expandindo aquilo que seria parte do escopo de suas funções vitais, permite a comunicação (mediante a proferição da palavra), entre "os canais muitos" e o mundo: "Um poro monstruoso que respira o mundo". Signos da subjetividade são também os qualificativos que lhe servem: "Arte medonha da paixão", sendo a boca arte (e aqui remetemos à ideia do artesão presente no poema anterior), causa do medo e causada por este, podemos supor, se tivermos em vista a violência implicada na ferida da qual resulta, e, sobretudo, paixão: signo do sofrimento - no sentido de que é passiva -, sofre as consequências de uma atividade. Ao que parece, entretanto, atividade e passividade são as duas manifestações de um único eixo subjetivo: boca e mundo, em que a palavra é, ela mesma, o elo unificador desse movimento (intimidade/exterioridade) que existe enquanto poema. ${ }^{230}$

Ainda um verso vale a nossa atenção: "Tubo sonoro por onde se coa o corpo."; e vale justamente pela manifestação que é daquilo que anuncia, isto é, a ênfase na sonoridade semanticamente expressa, coincide com a sensação sonora provocada pela leitura do verso em questão: a predominância do fechamento vocálico (notadamente

\footnotetext{
${ }^{228}$ MORAES, Eliane Robert. O corpo impossível. São Paulo: Iluminuras: 2005, p. 55.

${ }^{229}$ Idem, p. 71.
}

${ }^{230}$ A respeito da poesia de Luís Miguel Nava, é pertinente trazer para o presente contexto a relação que Ricardo Vasconcelos estabelece entre linguagem e corpo, tendo em vista a equivalência entre interioridade e exterioridade corporal e interioridade e exterioridade de sentido; esta última, possibilitada pela metáfora (uma vez que a metáfora pode ser entendida como um artifício de linguagem em que a significação literal se deslocaria - para uma exterioridade - em direção às significações figurativas mediante o contexto poético): "A fragmentação dos limites, nesta poética, solicitando espontaneamente uma forma de conhecimento erigida sobre a metáfora, põe em xeque a ideia de separação de sistemas fechados. Isto acontece uma vez que essa delimitação de espaços (interior/exterior) vive da permanente dupla possibilidade de ser preservada ou dissolvida, consoante se reconheça mais fácil ou mais difícil o acesso ao que vai dentro de cada um de nós ou a tudo quanto nos rodeia; por outras palavras, conforme concebamos uma barreira entre o nosso interior e o que nos rodeia, ou a recusemos, no pressuposto de que essa barreira entre nós e o mundo é um artifício." (VASCONCELOS, Ricardo. Campo de relâmpagos: leituras do excesso na poesia de Luís Miguel Nava. Lisboa: Assírio \& Alvim, 2009. p. 31). 
pela frequência com que ocorre a vogal "o") transforma a leitura do poema por meio das articulações necessárias que a boca deve fazer para efetuar essa leitura, num percurso pelo "tubo" que nós, leitores, somos: boca. Assim, enquanto tubo sonoro, nos reconhecemos mediante o ato da leitura, ou seja, é na pronúncia do verso em que existimos, ecoamos juntamente com os "os”, como há de ser a propagação do som no interior de um tubo. O verso em questão mostra de que maneira vida e obra ocorrem conjuntamente numa operação sempre sensorial, e daí que o corpo além da boca é convocado pelo procedimento de coar: na boca é que se coa o corpo - a boca, matéria primeira em que o "eu" se manifestaria (como propusemos), por onde passam ar, alimento, e, sobretudo, a matéria sonora que a palavra é em relação à carne - nesse coar há uma atividade própria mesmo de artesão, daquele que separa as matérias e faz penetrar o que no corpo se colhe. Está o corpo todo, desse modo, à serviço da boca: eis o poema, eis, portanto, vida/existência e obra coincidindo. Possibilidade operada pela revolução perceptiva empenhada mediante o ato criativo: o poema como espaço que torna viável a reinvenção subjetiva sem que tenha de prestar contas aos possíveis lógicos determinados pela razão funcional. Tal reinvenção, no caso de Herberto Helder, ocorre por meio de uma reorganização dos elementos corporais, em que a hierarquia é subvertida e a boca ocupa a maior posição de importância (a ponto de reger ou "coar" o corpo todo, ou seja, o sujeito mesmo). Outro dado se faz relevante: por tratar-se de um sujeito da escrita a metalinguagem é presença que não se pode ignorar: eis a possibilidade de considerar como metalinguístico este poema, conforme a interpretação decorrida, exatamente na linhagem teórica de Josette Rey-Debove, já que não apenas há vocábulos especializados que se encarregam de atestar a função metalinguística ("Desembocam, como se diz em nome"; "consumpção em voz alta, ou num murmúrio), mas a própria boca assume conotação metalinguística neste contexto (novamente ReyDebove, dessa vez acerca da afirmação que o contexto discursivo importa na identificação metalinguística), uma vez que a boca, ao enfatizar o sujeito da percepção como corpo, é também o órgão que remete à proferição da palavra: o próprio poema, portanto. Dessa forma, o elo entre vida/subjetividade e obra, está aqui cristalizado, sem que dele estejam excluídos os arcabouços perceptivos e metalinguísticos de que lançamos mão como possibilidade de leitura.

Também Jorge Fernandes da Silveira, em belo ensaio dedicado às conversações poéticas entre Herberto Helder, Fiama Hasse Pais Brandão e Gastão Cruz vai evidenciar a boca como lugar privilegiado em que ocorre a intersecção entre corpo e 
poema. Em referencia ao título do seu ensaio, a saber, "Acolher na boca", o ensaísta afirma: “(...) em literatura nada se prova, mas dá um sabor especial ao verbo usá-lo em título tão apurado como esta colher, de ouro já, experimentando as suas muitas e variadas ementas." 231 e, algumas páginas a seguir:

voltar à realidade da poesia, à sua textualidade, é o convite para que o trabalho poético saiba acolher na boca o poema, quer dizer, sinta prazer na sua leitura, e para que «depois no chão dos olhos», quer dizer, no poema $(\mathrm{a} / \mathrm{re})$ colhido pela boca, tenha apre(e)ndido que o real tem mais sabor quando passa pela prova de fogo da escrita. ${ }^{232}$

Importa ainda retomar essa ideia que, há pouco e timidamente, esboçamos sobre o sujeito que se esconde. Logo recuamos, dizendo que o pronome "eu" estaria implícito na imagem da "boca", e dizemos, mais enfaticamente, que a subjetividade no poema é manifesta a despeito da verbalização do pronome em primeira pessoa, este "eu" que, conforme vimos na metafísica cartesiana, seria uma espécie de entidade mental, completamente alheia a qualquer manifestação orgânica.

Recorremos, para maior possibilidade de reflexão, a alguns trechos do poema III ${ }^{233}$, de Poemacto ${ }^{234}$, publicado primeiramente em 1961: "O actor acende a boca. Depois, os cabelos./ Finge as suas caras nas poças interiores.”. Antes de tudo, vale tecer algumas considerações sobre o título do livro: o poema é ato, ou seja, pressupõe ação por parte do sujeito da escrita e agir é sempre agir sobre algo, manifestação que carrega em si a potência da modificação. Daí que pensar na figura do ator como aquele que age sobre o poema e com o poema se modifica (“(...) acende a boca ${ }^{235}$. Depois, os cabelos"), nos permite complexificar a relação estabelecida com o fingimento. O

${ }^{231}$ SILVEIRA, Jorge Fernandes da. "Acolher na boca, depois no chão dos olhos: o poema (Ou o dia em que Herberto Helder de uma queda foi ao chão da mão de Fiama Hasse Pais Brandão)"In: Diacrítica. Braga: Universidade do Minho, n²3/3, pp. 83-100, 2009, p. 92.

${ }^{232}$ Idem, p. 96.

${ }^{233}$ HELDER, Helberto. Oficio Cantante. Lisboa: Assírio \& Alvim, 2009, p. 114-117.

${ }^{234}$ Em confluência com a leitura que venho fazendo, as seguintes palavras de Manuel Gusmão: "Há na poesia de Herberto Helder uma poética (...) trata-se em geral de gestos e figurações de uma poética imanente ao poema, que não se diz de fora ou ao lado da poesia, e que se furta a uma suposta e ilusória transparência do pensamento da poesia sobre si própria, antes é movimento do poema fazendo-se e refletindo-se. Por aí, "o poema" mais do que o tema de um discurso é uma "personagem" ou uma figura indissociável do movimento do mundo verbal em que se inscreve (...)." (GUSMÃO, Manuel. "Herberto Helder, 'a estrela plenária;” In: Tatuagem e palimpsesto. Lisboa: Assírio \& Alvim, 2010, p. 379).

${ }^{235}$ Exatamente como no poema lido anteriormente, a boca como o lugar da iluminação. 
fingir, assim como o esconder-se carregam o sentido de velar qualquer espécie de verdade ou essência. A verdade, nesse caso, seria decorrência de uma forma de ação muito própria, em que não só não estariam implicados o ato de fingir e o ato de esconder-se, mas tais modos de ação deveriam ser completamente eliminados para que não maculassem a verdade. Ora, esse modo de entendimento é completamente subvertido por Herberto Helder, que parece conotar o fingimento como ação que é, em si mesma, uma forma de verdade. E dizemos uma forma de verdade, uma vez que o ato de fingir conduz a uma mobilidade inesgotável: tudo pode ser fingido, e as verdades advindas de cada um dos fingimentos são, portanto, múltiplas. Não há ninguém por trás da máscara, é como se dissesse. E na mesma esteira de raciocínio, há que se supor que a identidade é qualquer coisa de tão maleável que o ator/poeta pode recriar-se conforme as exigências de cada combinação vocabular, tudo estaria a serviço do artesão que se esculpe a si mesmo.

Justificamos essa proposta de leitura em que os diversos fingimentos seriam a única forma de verdade alcançável, especialmente pela reversão que o ato de fingir opera: não se volta para o exterior, como seria de se supor, não visa a um objetivo situado fora, mas atua mesmo por dentro deste sujeito, isto é, constitui o sujeito, é sua forma de ação primordial: "Finge as suas caras nas poças interiores.". Se alcança o lado de fora, por assim dizer, isso se deve a essa difusão que advém do seu modo de "agir poeta": "Fala devagar./ Parece que se difunde aos bocados./Bocado estrela./Bocado janela para fora./ Outro bocado gruta para dentro", e aqui importa mencionar - para além de reiterar esse modo de difusão que inclui tanto o interior quanto o exterior - essa espécie de eco em relação ao poema anterior, em que a fala, mediante a boca, acontece aos "bocados", isto é, como se os "bocados" fossem ações sucessivas empenhadas pela boca.

Com o intuito de reforçar a metalinguagem presente nesse ato de escrita (e na fusão da escrita com a vida, uma vez que o que está em jogo é justamente a ênfase no fato de que não há verdade para além do que se cria e, sendo a vida simultânea a essa criação, não seria possível supor uma "vida verdadeira" de onde se parte, referencial anterior à criação, já que a vida é aquilo que a cada momento a ação do ator faz acontecer ${ }^{236}$, trazemos os seguintes versos do mesmo poema: “O actor é um advérbio

\footnotetext{
236 Mais uma vez, em confluência com o pensamento de Merleau-Ponty, para quem a verdade cartesiana, universal e imutável, é convertida nas operações sempre transitórias da percepção.
} 
que ramificou/ de um substantivo./ E o substantivo retorna e gira,/ e o actor é um adjectivo./ É um nome que provém ultimamente/ do Nome./ Nome que se murmura em si, e agita,/ e enlouquece./ O actor é o grande Nome cheio de holofotes./ O nome que cega./ Que sangra./ Que é o sangue./ Assim o actor levanta o corpo,/ enche o corpo com melodia./ Corpo que treme de melodia./ Ninguém ama tão corporalmente como o actor./ Como o corpo do actor.".

Neste trecho, a fusão entre ato de escrita (metalinguagem) e corpo ocorre de maneira exemplar: supor o ator (aquele que age, atua, promove a ação, este "grande Nome" com propriedades de verbo ${ }^{237}$ e que, como o dançarino e o performer, mais do que quaisquer outros artistas - o pintor, o escultor, o instrumentista - se funde com o resultado de sua criação, no sentido de que a sua matéria prima é o próprio corpo) como um advérbio - classe de palavra que na gramática atua como modificador, predominantemente, do verbo ${ }^{238}$-, implica numa fusão em que os sentidos das classes de palavras explicitadas (vale enfatizar ainda o adjetivo como modificador do substantivo) acabam por contribuir para a confluência de modificações potenciais advindas destas mesmas classes de palavras. O que parece que está em jogo é, como já dissemos no capítulo inicial, a metamorfose como princípio. Este princípio destina-se aqui às ações que têm no corpo o seu lugar de ocorrência: novamente o sangue em destaque, daí que a vida, vale referir ainda uma vez, é sangue em movimento no corpo do ator. O corpo, ele mesmo, assume forma de advérbio ("corporalmente") nessa cadeia rotativa de modificações relacionais, sendo que o movimento é a verdade base para todas as verdades decorrentes (e em constante movimento de transformação) do ato da escrita.

Importa ainda algum comentário dos seguintes versos: "Ninguém ama tão desalmadamente como o actor./ O actor acende os pés e as mãos.”, em que poderíamos contrastar o corpo transformado em advérbio, com a "desalma" também na mesma

\footnotetext{
${ }^{237}$ E o dizemos, uma vez que o "verbo é uma palavra de forma variável que exprime o que se passa, isto é, um acontecimento representado no tempo" (CUNHA, Celso e CINTRA, Lindley. Nova gramática do português contemporâneo. Rio de Janeiro: Nova Fronteira, 2001, p. 379), isto é, o verbo como a classe de palavra em que os acontecimentos tomam forma e, mais do que isso, como aquele que varia, modifica-se conforme o tempo, o modo, a pessoa, etc.

${ }^{238}$ Embora também modifique o adjetivo, outro advérbio e, em circunstâncias esporádicas, o substantivo: "Certos advérbios são assinalados em função de modificador de substantivo, principalmente, quando este é entendido não tanto enquanto substância, mas enquanto qualidade que esta substância apresenta: Gonçalves Dias é verdadeiramente poeta". (BECHARA, Evanildo. Moderna gramática portuguesa. Rio de Janeiro: Editora Lucerna, Nova Fronteira, 2006, p.288).
} 
condição gramatical, e daí sugerir a afirmação do corpo e a negação da alma como aspectos que agem sobre a ação transformadora da gramática. Ora, a alma seria então o "anticorpo", um topos metafísico que, entretanto, aparece no poema por meio de outra variação: "O actor que subtrai Deus de Deus,/ e dá velocidade aos lugares aéreos./ Porque o actor é uma astronave que atravessa/ a distância de Deus./ Embrulha. Desvela./ O actor diz uma palavra inaudível.". A palavra "Deus" se apresenta aqui como uma espécie de impossibilidade corpórea: a "palavra inaudível" (não sensibiliza o ouvido) e, entretanto, não deixa de ressoar nas linhas do poema, ainda que como impossibilidade. Ou poderíamos pensar de outro modo: o que ressoa é a transformação da palavra e, portanto, a transformação de seu significado: a subtração de Deus em relação a si próprio, nada mais é do que o reflexo da ação transformadora do ator que opera metamorficamente com a materialização do vocábulo: das conotações metafísicas de Deus a uma astronave. Dessa metamorfose operada pelo labor do ator, o sujeito da ação se torna apto para embrulhar e desvelar o lugar aéreo mediante o corpo da matéria palpável (astronave).

Destes poemas ou trechos de poemas que elegemos para refletir sobre o corpo na elaboração do sujeito da escrita, importa dizer que resultam na construção de uma identidade poética intimamente relacionada com a transformação das matérias, seja essa transformação implicada num movimento de circularidade, seja implicada num movimento de ressignificação operado pelas influências entre as vizinhanças vocabulares. Essa identidade, muito marcada pela circunscrição do corpo em contato com a matéria do mundo, se constrói na escrita ${ }^{239}$, daí a recorrência da mão e da boca,

\footnotetext{
${ }^{239}$ A ideia que venho insistentemente desenvolvendo acerca da constituição subjetiva, foi pensada, com derivações diversas, também por Rosa Maria Martelo, que defende, diferentemente, a subjetividade como uma via de mão dupla, uma vez que, embora reconheça a indissociabilidade entre autor e obra, a crítica atenta para a dissolução subjetiva implicada nessa forma de fusão: “(...) é importante acrescentar que o título Ofício Cantante tinha sido usado por Herberto Helder na primeira recolha dos seus livros de poesia, em 1967, depois da qual o poeta organizou outras recolhas, já com a inclusão de obras posteriores, sob os títulos Poesia Toda e Ou o Poema Contínuo. Lido a seguir ao nome do autor, como normalmente acontece no rosto de um livro, este último título iniciado pela disjuntiva inclusiva "Ou", sugere uma total identificação entre o nome da obra e o nome de autor, fazendo de "Herberto Helder" um sinónimo de "o poema contínuo" e estabelecendo, entre ambos, um vínculo e uma permutabilidade incontornáveis. Como inúmeras vezes é afirmado nos poemas, as imagens, o som, o ritmo dos versos supõem uma voz e um corpo, mas os textos pretendem funcionar como "carnagem sonora" (2009: 355), como uma dobra reflexiva do mundo apenas possível em função do processo de des-subjectivação resultante da escrita." (MARTELO, Rosa Maria. "Herberto Helder, o nome da obra" In: José Quaresma (coord.). Gravura, Instalação e Poesia. A Alegria de um encontro. Printmaking, Installation and Poetry. The Joy of a Reunion. Lisboa: CIEBA-FBAUL, 2012, pp. 44-48. https://www.academia.edu/12440862/Herberto_Helder_o_nome_da_obra, p. 2). Diz ainda: “(...) a mais exultante experiência de des-subjectivação alguma vez conseguida na poesia portuguesa” (p. Idem, 4) e, em outro ensaio: “(...) a evocação do acto poético coloca o leitor diante do paradoxo de conceber uma
} 
uma vez que são as partes do corpo estreitamente relacionadas aos ofícios da palavra. O sangue, de outro modo, acaba por conotar o ato da escrita com uma vitalidade própria, é como se o poema fosse dotado de vida na presença do sangue, de forma que a retórica presente nessa metalinguagem, é aquela que ilude o leitor diante dessa espécie de poema-corpo. Não só a metalinguagem, mas também a metáfora, uma vez que o sentido do sangue expande-se, nessa relação corpo-escrita, para o sentido da tinta da caneta sobre o papel (como muito bem desenvolveu Ricardo Vasconcelos: "O trabalho da metáfora assenta precisamente nesse jogo de dupla polarização que é a criação de sentido por causa e apesar da literalidade. ${ }^{, 240}$ ).

A transformação, portanto, está em completa consonância com as propriedades do corpo: em constante modificação, é corruptível, perecível (por isso a temática da morte tão recorrente); diferentemente das propriedades da alma: essencial e imutável, a alma seria essa espécie de verdade única e impronunciável e, justamente por esse motivo, inacessível ao corpo, que se delimita na pronúncia e na escuta da pronúncia, no toque, no olfato, na visão e no paladar, possuindo, assim, múltiplas verdades, tantas quantas a percepção conseguir conjugar.

\footnotetext{
intensa figuração de autor em função da sua transmutação em poema: uma intensificação da figuração autoral que decorre da dissolução da autoria. É uma síntese tão radical quanto improvável: por ela regressa a hipertrofia romântica do sujeito, não para se opor à sua dissolução moderna, mas para a atravessar, e para, por dentro dela, através dela, voltar a ser possível. (MARTELO, Rosa Maria. "Assassinato e assinatura" In: A forma informe: leituras de poesia. Lisboa: Assírio \& Alvim, 2010, p. 111). Manuel Gusmão, já em 2001, estava atento a esta mesma questão e, mais conforme a noção de constituição subjetiva que aqui defendo, afirma: "Como o título abre com um "Ou" (com maiúscula inicial), os nossos hábitos linguísticos levam-nos a procurar algo que deveria estar antes: "X ou [...]". Ora, na "caixa" ou no "selo", o que vem antes é apenas o nome do Autor. Lendo assim, "Herberto Helder" emigra da sua condição de nome de autor (que reenvia para um indivíduo humano concreto) para a condição de texto, de fragmento textual de um título. Dito de outra maneira, deixa de ser apenas o nome do poeta, do agente, para ser parte da obra. Ou ainda: "Herberto Helder é a poesia toda Ou o poema contínuo". E, entretanto, isso não significa necessariamente uma essencialização da poesia. Nessa migração, a individualidade do indivíduo não se dissolve na trama do texto, antes se transforma num modo da singularização desta escrita." (GUSMÃO, Manuel. "Leiam Herberto Helder Ou o Poema Contínuo" In: Tatuagem e palimpsesto. Lisboa: Assírio \& Alvim, 2010, p. 364).
}

${ }^{240}$ VASCONCELOS, Ricardo. Campo de relâmpagos: leituras do excesso na poesia de Luís Miguel Nava. Lisboa: Assírio \& Alvim, 2009, p. 110. 


\subsection{Mário Cesariny e o nome porvir}

$\mathrm{Na}$ esteira do primeiro poema de Herberto Helder que lemos no item anterior, trazemos um poema de Cesariny, reproduzido a partir da terceira edição de Pena Capital $^{241}$, em que o nome em relação ao corpo/existência também é colocado em evidência:

a antonin artaud

I

Haverá gente com nomes que lhes caiam bem.

Não assim eu.

De cada vez que alguém me chama Mário

de cada vez que alguém me chama Cesariny

de cada vez que alguém me chama de Vasconcelos

sucede em mim uma contracção com os dentes

há contra mim uma imposição violenta

uma cutilada atroz porque atrozmente desleal.

Como assim Mário como assim Cesariny como assim ó meu deus de Vasconcelos?

Porque é que querem fazer passar para o meu corpo

uma caricatura a todos os títulos porca?

Que andavam a fazer com a minha altura os pais pelos baptistérios

para que eu recebesse em plena cara semelhante feixe de estruturas

tão inqualificáveis quanto inadequadas

ao acto em mim sozinho como a vida puro

eu não sei de vocês eu não tenho nas mãos eu vomito eu

não quero

eu nunca aderi às comunidades práticas de pregar com pregos

as partes mais vulneráveis da matéria

Eu estou só neste avanço

de corpos

${ }^{241}$ CESARINY, Mário. Pena Capital. Lisboa: Assírio \& Alvim, 2004, p. 49-51. 
contra corpos

Inexpiáveis

O meu nome se existe deve existir escrito nalgum lugar «tenebroso e cantante»

suficientemente glaciado e horrível

para que seja impossível encontrá-lo

sem de alguma maneira enveredar pela estrada

Da Coragem

porque a este respeito - e creio que digo bem -

nenhuma garantia de leitura grátis

se oferece ao viandante

Por outro lado, se eu tivesse um nome

um nome que me fosse realmente o meu nome

isso provocaria

calamidades

terríveis

como um tremor de terra

dentro da pele das coisas

dos astros

das coisas

das fezes

das coisas

II

Haverá uma idade para nomes que não estes

haverá uma idade para nomes

puros

nomes que magnetizem

constelações

puras

que façam irromper nos nervos e nos ossos

dos amantes 
inexplicáveis construções radiosas

prontas a circular entre a fuligem

de duas bocas

puras

Ah não será o esperma torrencial diuturno

nem a loucura dos sábios nem a razão de ninguém

Não será mesmo quem sabe ó único mestre vivo

o fim da pavorosa dança dos corpos

onde pontificaste de martelo na mão

Mas haverá uma idade em que serão esquecidos por completo

os grandes nomes opacos que hoje damos às coisas

Haverá

um acordar

A começar pela dedicatória que se confunde com o título do poema ${ }^{242}$ : se pensada em conjunção com os primeiros versos, faz-nos atentar para a extensão que as reflexões que o nome próprio abarca em termos de outros nomes (no caso, outro nome próprio...). Ora, um poema dedicado a Antonin Artaud - surrealista polêmico, uma vez que foi alvo tanto das palavras mais repreensivas quanto das palavras mais entusiastas que André Breton poderia ter dirigido aos companheiros de movimento ${ }^{243}$ - que logo

\footnotetext{
${ }^{242}$ Afirmamos essa ambiguidade entre dedicatória e título devido ao padrão dos títulos dos demais poemas desta edição do livro (todos em letras minúsculas) com o qual coincide "a antonin artaud".

${ }^{243}$ Importa dizer que em 1930, data de publicação do Segundo Manifesto Surrealista, Breton não poupa argumentos para justificar a expulsão de Artaud do grupo. De acordo com o "papa do surrealismo francês": "eu me havia prometido (...) abandonar silenciosamente a seu triste destino alguns indivíduos que me pareciam já terem feito suficientemente justiça própria: era o caso dos srs. Artaud, Carrive, Gérard, Limbour, Masson, Soupault e Vitrac (...)" (BRETON, André. Manifestos do surrealismo. São Paulo: Editora Brasiliense, 1985, p. 104). A seguir, discorre longamente sobre o caso de Artaud, contra quem parece se indispor em especial: "Que um ator com fito de lucro e de gloríola empreenda montar luxuosamente uma peça do vago Strindberg, à qual ele mesmo não dá nenhuma importância, claro, eu não veria nisso nenhum inconveniente particular se este ator não tivesse passado, de tempos em tempos, por homem de pensamento, de cólera e de sangue (...)” (Idem, p. 105). Graças à indicação de Claudio Willer, querido surrealista e grande divulgador do surrealismo no Brasil, somos notificados de que esse desentendimento é, entretanto, passageiro: "Artaud e Breton se reconciliaram em 1936. Corresponderam-se." (WILLER, Claudio. "André Breton e Antonin Artaud" http://claudiowiller.wordpress.com/2012/02/03/andre-breton-e-antonin-artaud/). $\mathrm{Na}$ mesma nota disponibilizada por Willer, lemos que em 1952, é publicado Entrétiens, livro feito a partir de entrevistas
} 
nos primeiros versos faz uma incursão sobre o nome próprio, já é indício de uma subjetividade flutuante. E dizemos que a subjetividade flutua num sentido muito preciso, conforme encontramos em acepção do Novo Aurélio: “flutuar. (...) 2. Pairar ou mover-se em equilíbrio no espaço", e a partir daí sugerimos que há um equilíbrio conquistado na mobilidade que implica essa relação com outros nomes. Não qualquer outro nome, mas o nome de um surrealista que afirmou, em Umbigo dos limbos: "Eu não concebo nenhuma obra separada da vida" ${ }^{244}$. Novamente, a pertinência de trazer do conceito de carne relacional em Merleau-Ponty, sobretudo pela ênfase na mobilidade que proporciona, nos trânsitos que boicotam a lógica estática e segmentada.

Diferentemente do que vimos ocorrer no caso de Herberto Helder, o nome aqui enunciado é mesmo o nome do Mário Cesariny, com a especificação devida de sobrenome, o que lemos como um atestado indubitável da coincidência entre vida e obra, exatamente como queriam os surrealistas, exatamente como explicitou Artaud. De acordo com Josette Rey-Debove: “Le nom propre n'appartient pas au code d'une langue, mais à un autre code (...). Les noms propres ont un contenu dénotatif qui relève de la connaissance du monde et non pas de la compétence langagière" ${ }^{245}$. Enquanto em Herberto Helder a metalinguagem se ocupa de estabelecer a relação entre vida e obra - no sentido de que a obra/o poema ganha tal autonomia que é como se tivesse corpo, como se nele corresse o sangue, circulasse o ar -, em Cesariny a própria vida (ou, a vida própria...) é referente da atuação escrita ${ }^{246}$, já que, como vimos no capítulo anterior, o valor da escrita não é devido ao resultado estético ou à engenharia verbal, mas ao poder de atuar a favor de uma vida liberta daquilo que o surrealismo considera como grilhões morais e epistêmicos. Por isso a recusa do nome próprio que se enuncia. Se por um lado a verbalização do nome se

radiofônicas, em que o tom elogioso de Breton em referência à Artaud é bastante evidente: "ninguém como ele pôs mais espontaneamente todos os seus meios, que eram grandes, ao serviço da causa surrealista (...) Talvez o seu conflito com a vida fosse maior do que o de nós todos. Belíssimo, como era então, ao deslocar-se arrastava consigo uma paisagem de romance negro, trespassada de relâmpagos. Estava possuído por uma espécie de furor que não poupava, por assim dizer, nenhuma das instituições humanas, mas que por vezes podia resolver-se num riso onde transparecia todo o desafio da juventude. Esse furor, pelo seu espantoso poder de contagio, influenciou profundamente a acção surrealista." (BRETON, André. Entrevistas. Lisboa: Edições Salamandra, s/d, pp. 113, 114).

\footnotetext{
${ }^{244}$ ARTAUD, Antonin. Linguagem e vida. São Paulo: Editora Perspectiva, 2008, p. 207.

${ }^{245}$ REY-DEBOVE, Josette. Le metalangage. Montréal: Le Robert, 1986, pp., 270, 271. ${ }^{246}$ Numa dupla alusão: a um título de poema de Pedro Oom, e à noção do poema como ato, conforme
lemos em Herberto Helder.
} 
ocupa de estabelecer o vínculo com a pessoa empírica de Cesariny, por outro lado é atestado da insuficiência que este nome carrega em termos de possibilidades subversivas, conforme veremos na leitura do poema. Exatamente nessa linha de entendimento é que a obra coincide com a vida (vale relembrar, na esteira da proposta de abordagem de Maingueneau), já que o poema acaba por ser uma das formas de manifestação da surrealidade, uma das vias possíveis dos modos de perceber e atuar sobre o mundo próprios ao surrealismo.

Sobre tais modos de atuação, nota-se no poema que a identidade de que se recobre o sujeito a partir do nome próprio é colocada em questão. Mais do que isso, a identidade é convertida em "uma caricatura a todos os títulos porca". Ora, a presença de Artaud como destinatário/título do poema se manifesta como essa espécie de duplo real $^{247}$, em relação ao qual o sujeito da escrita parece se estender: sucessivamente banido por "uma cultura que nunca coincidiu com a vida e que é feita para reger a vida" 248 , Artaud se empenhou numa luta contra qualquer forma de cerceamento.

É contra o cerceamento identitário implicado na ideia de adesão cultural, expresso por meio da dupla metonímia: a figuração da família e da religião, que essa "identidade eletiva", por assim dizer, alcança em Artaud e em suas propostas a justificativa maior da recusa de Cesariny. Sobre a família, temos o nome como decorrência de um elo que reproduz uma tradição de moldes identitários, não apenas porque é a família que escolhe o nome do filho, mas, ainda, porque o filho partilha com a família um mesmo sobrenome, obedecendo a uma convenção que explicita pela palavra a consanguinidade. A religião aparece, aqui, mediante a menção ao batismo, que, para além de significar o ato de nomear (novamente a definição de uma identidade, nesse contexto, mediante a imposição de um dogma com implicações morais), remete imediatamente ao sacramento da Igreja Católica, que marca o rito de iniciação ao catolicismo.

\footnotetext{
${ }^{247}$ Para aproveitar o termo que compõe o título do livro, O teatro e seu duplo, talvez o mais conhecido de Artaud, em que o duplo (ou as sombras) seria o resultado da elaboração de uma realidade proporcionada pela entrega vital que o corpo do ator, não mais regido pelas imposições culturais $\mathrm{e}$ lógicas, mas como meio de uma codificação sensorial, seria capaz de viabilizar. A exposição dessa ideia encontra-se dispersa ao longo de todo o livro, mas vale aqui mencionar um trecho no qual podemos entrever a força argumentativa da qual se reveste o corpo na criação desse duplo real e com especial ênfase para a valorização do aspecto coletivo: "O teatro é o único lugar e o último meio de conjunto que nos resta para alcançar diretamente o organismo e, nos momentos de neurose e baixa sensualidade como este em que estamos mergulhados, para atacar essa baixa sensualidade através dos meios físicos aos quais ela não resistirá" (ARTAUD, Antonin. O teatro e seu duplo. São Paulo: Martins Fontes, 1999, p. 91.).

${ }^{248}$ Idem, p.1.
} 
Vale relembrar ainda a importância que a prática de grupo assume para os surrealistas, como já vimos no caso de Cesariny e, em Artaud, podemos conferir um empenho semelhante: "Basta de poemas individuais e que servem muito mais a quem os faz do que a quem os lê. Basta, de uma vez por todas, de manifestações de arte

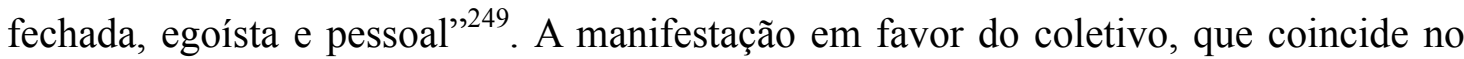
caso de Cesariny e de Artaud, ganha então contornos identitários, por isso dissemos da subjetividade flutuante expressa na recusa do nome próprio e do direcionamento em relação a Artaud. Essa operação não ocorre sem que haja uma guinada perceptiva, uma atenção, conforme Merleau-Ponty, aos modos de decodificação de uma linguagem/visão de mundo estabelecidas na cerca identitária imposta pela razão normativa; mais uma vez, as palavras oportunas do filósofo: “(...) como a minha imagem capta o meu ato de tocar, a imagem visual dos outros também o capta: eles são também o fora de mim. E eu sou o interior deles. Eles me alienam e eu os incorporo. Eu vejo pelos olhos de outrem - o mundo ${ }^{, 250}$

Sobre esse aspecto é imprescindível considerar que a coletividade só é um valor se estiver a favor da causa surrealista, uma vez que não há empenho mais coletivo do que aquele que resulta da cultura instituída, de suas adesões morais e da consequente normatização da conduta e da unilateralidade epistêmica resultante do império da lógica sobre os modos de condução do conhecimento.

A partir disso, temos que o surrealismo é simultaneamente um "não" e um "sim", isto é, só pode afirmar-se mediante a negação das estruturas que o coíbem. O "não", desse ponto de vista, deve ser anterior ao "sim", exatamente como ocorre na estrutura do poema, em que a primeira parte, com ênfase para as duas primeiras estrofes, se encarrega dessa recusa - e aí, um dado que nos interessa em especial - que é consequência de uma violência sentida no corpo: "sucede em mim uma contracção com os dentes/ há contra mim uma imposição violenta/ uma cutilada atroz porque atrozmente desleal". Ora, os dentes contraídos indicam impossibilidade de pronúncia, de forma que parece haver um desequilíbrio entre a fala dos outros e a fala do sujeito que não se reconhece nessa delimitação de batismo. A fala do sujeito configura-se mesmo como uma impossibilidade e essa impossibilidade ocorre no corpo, núcleo da vida, ou seja, a vida como decorrência da ação do sujeito está em suspenção: é mesmo

\footnotetext{
${ }^{249}$ Idem, pp. $88,89$.

${ }^{250}$ MELEAU-PONTY, Maurice. A natureza. São Paulo: Martins Fontes, 2006, p. 440.
} 
abalada, colocada em risco por uma facada, "cutilada atroz", já que o sujeito sofre a ação do pronunciamento alheio acerca de si mesmo: por meio dessa imagem, sugerimos que a imposição da palavra do outro (com especial atenção para o fato de que a palavra em questão é aquela que define uma identidade social) se configura como uma ameaça à vida do sujeito.

Se o sujeito se apresenta como um ato de negação da cultura instituída, ele se coloca diante dela como um solitário: alguém que recebeu em "plena cara semelhante feixe de estruturas/ tão inqualificáveis quanto inadequadas/ ao acto em mim sozinho como a vida puro". Se dissemos em outro momento do empenho coletivo, dizemos que em relação à estrutura que o sujeito recusa, a solidão é evidenciada. O sujeito sozinho, por outro lado, é também uma afirmação, já que ele se apresenta "puro" diante da vida (a sua vida que, portanto, extrapola os limites do nome próprio recebido no batismo), e "puro", talvez, no sentido de que não se deixou misturar com qualquer "outro" representante da nomenclatura oficial, por assim dizer. Essa pureza é acentuada pela posição que o adjetivo ocupa no verso: no canto direito, fim de verso, é separado dos vocábulos anteriores pelo espaço gráfico, como se não se misturasse. Vale atentar para a recorrência do adjetivo que aparece novamente na primeira estrofe da segunda parte, com as devidas variações de número e gênero. Lemos, subsequentemente: "puros" ( $3^{\circ}$ v., $1^{\mathrm{a}}$ estr., parte II ), "puras" (6 $6^{\mathrm{o}}$., $1^{\mathrm{a}}$ estr., parte II), "puras" $\left(12^{\mathrm{o}}\right.$ v., $1^{\mathrm{a}}$ estr., parte II), e, também aqui, a composição gráfica do poema ressalta o seu caráter semântico: o vocábulo, nas três ocorrências, é componente único de cada um dos versos. Se atentarmos ainda, para a variação de gênero e número, como uma progressão do singular ao plural, e de um gênero (masculino) para dois gêneros (masculino e feminino: de alguma forma, também uma variação numérica...), podemos sugerir uma ênfase no sentido da expansão do sujeito da escrita. Curioso, e mais ainda, é que a pureza - num primeiro momento, signo da não mistura - pode ser lida, de acordo com as variações morfológicas que apresenta ao longo do poema, como uma via de convergência. Talvez a pureza como um qualificativo que incida sobre o signo da integridade, da fidelidade a uma proposta inicial, um golpe perceptivo que, como queria Merleau-Ponty, seja capaz de inaugurar as formas de relações do sujeito com o mundo de maneira autêntica.

Adiante, lemos: "Eu estou só neste avanço/ de corpos/ contra corpos/ Inexpiáveis", em que os corpos ou as vidas (subjetividade por meio da materialidade) que se manifestam em atrito, seriam os mesmos corpos/vidas que não podem se 
purificar, pois que estariam por demais infectados pelos "feixes de estruturas" que obedecem aos ditames da cultura instituída.

A negação é reiterada, bem como são reiterados os efeitos que essa espécie de luta surte no corpo: "eu não sei de vocês eu não tenho nas mãos eu vomito eu/ não quero/ eu nunca aderi às comunidades práticas de pregar com pregos/ as partes mais vulneráveis da matéria". Quando diz "eu não tenho nas mãos", sem que esteja especificado o objeto da oração, é como se não houvesse nada (qualquer coisa) que pudesse ser tomado como propriedade, talvez, no sentido mesmo do que lhe é próprio, como o seria o nome de batismo; e, mediante a expressão "eu vomito", nota-se a violência com que o corpo reage àquilo que lhe prejudica, num ímpeto brusco de colocar para fora, de deslocar o alimento com que toda a gente que pactua com a cultura instituída se nutre em refeições diárias. A refeição como um rito, vale frisar, é signo do triunfo do pacto social, acentua e ordena a passagem do tempo: a rotina de trabalho, a rotina familiar, os almoços de domingo, os restaurantes; a vida medida pelos intervalos que a refeição estabelece, pelos encontros sociais que ela propicia, pelas regras de comportamento de que resulta. De todo modo, é sempre a busca pela subjetividade mediante as sensações corporais, é sempre a percepção a se manifestar como recusa e, mediante essa recusa, é que podemos perseguir esse sujeito que se apresenta ao leitor, como se diante de um espelho para o qual dirige sua meta em metamorfose.

A noção de identidade como uma delimitação estabelecida pelos códigos culturais que Cesariny recusa tão veementemente é de tal modo subvertida que, conforme podemos ler em Autografia I (primeira citação) e em Autografia II (segunda citação), tudo aquilo que poderia implicar numa delimitação estreita é ultrapassado: "Sou um homem/ um poeta/ uma máquina de passar vidro colorido" ${ }^{251}$. Em "máquina de passar vidro colorido", podemos notar aspectos que apontam para uma expansão subjetiva: uma máquina (possível metáfora do corpo e seu funcionamento) por onde passam coisas, ora, uma máquina permeável, que permite que vidros coloridos transitem por ela, com especial atenção para o fato de que o vidro é transparente e a sua transparência permite que se veja para além do limite material que encerra, por outro lado, a multiplicidade das cores que aponta, justamente, para diversidade acolhida; e "era uma vez este homem/ que era um chevrolet/ casado com uma mulher

${ }^{251}$ CESARINY, Mário. Pena Capital. Lisboa: Assírio \& Alvim, 2004, p. 36-38. 
de vidro" ${ }^{252}$, novamente a transparência implicada, com o acréscimo da ideia de mobilidade e deslocamento abarcada pela imagem do chevrolet: um sujeito em movimento, que não se fixa, o sujeito mesmo da percepção, como queria MerleauPonty.

Ainda algumas palavras sobre o efeito da negação: nos versos "eu nunca aderi às comunidades práticas de pregar com pregos/ as partes mais vulneráveis da matéria”, a recusa diante da ordenação do mundo com vistas a uma maior utilidade de meios se dirige ao aspecto material e mais, o que o sujeito recusa é a fixação, mediante a imagem dos pregos, daquilo que na matéria seria o mais frágil (vulnerável): a intervenção levada a cabo por tais "comunidades" supõe ainda uma espécie de comodidade, justamente porque investe sua ação na qualidade da matéria que mais facilmente pode ser manipulada.

Nas estrofes seguintes a presença de Artaud se deixa entrever pela crueldade vocabular que compõe a hipótese do nome próprio: "O meu nome se existe deve existir escrito nalgum lugar «tenebroso e cantante» suficientemente glaciado e horrível” e, algumas linhas depois: "Por outro lado, se eu tivesse um nome/ um nome que me fosse realmente o meu nome/ isso provocaria/ calamidades/ terríveis/ como um tremor de terra/ dentro da pele das coisas/ dos astros/ das coisas/ das fezes/ das coisas". Ora, Artaud fala em defesa de um teatro que seja como a peste:

Se o teatro essencial é como a peste, não é por ser contagioso, mas porque, como a peste, ele é a revelação, a afirmação, a exteriorização de um fundo de crueldade latente através do qual se localizam num indivíduo ou num povo todas as possibilidades perversas do espírito. Assim como a peste, ele é o tempo do mal, o triunfo das forças negras que uma força ainda mais profunda alimenta até a extinção. Há nele, como na peste, uma espécie de estranho sol, uma luz de intensidade anormal em que parece que o difícil e mesmo o impossível tornam-se de repente nosso elemento normal. ${ }^{253}$

Assim seria o nome deste sujeito que se busca pela escrita, uma identidade que se constitui a partir do rompimento com os limites morais que delimitam o bem e o mal ("calamidades terríveis"), do rompimento com os limites da conduta oficial que recusa o sujo, o feio, o excremento (as "fezes") e, em especial, do rompimento com o limite imposto pelo próprio corpo, uma vez que este nome seria capaz de ultrapassar a pele

\footnotetext{
${ }^{252}$ Idem, p. 39-41.

${ }^{253}$ Idem, p. 27.
} 
das coisas, dos astros, seria o nome próprio uma ação violenta da matéria do corpo contra a matéria do mundo num empenho similar àquele relatado por Artaud, no sentido de deixar transparecer as possibilidades perversas soterradas pelas limitações sociais. Eis o surrealismo: a busca pelos nomes a despeito de qualquer limite; uma busca que aparece fortemente na conjunção que propusemos entre fenomenologia e metalinguagem, já que a fenomenologia se pronuncia em favor dessa espécie de percepção inaugural (que, para ocorrer, deve, necessariamente haver o rompimento com os limites estabelecidos - como vimos com Merleau-Ponty, pois tais limites cerceariam a percepção ao impor sua codificação mediante os padrões culturais); e a metalinguagem, por sua vez - mediante a evidenciação da busca pelo nome (a um só tempo signo da linguagem e da subjetividade, já que se trata de um nome próprio) -, se encarrega de atentar para o fato da linguagem enquanto condição perceptiva, isto é, linguagem e percepção associados na atualização poétca.

Eis ainda o surrealismo como forma de metamorfosear a valoração tão severamente assimilada: transformar em luz, as trevas, num procedimento, entretanto, que em nada se assemelha com a proposta iluminista, que metaforizou a razão (e, portanto a "justa medida", inclusive no que se refere à moral) mediante qualidades de clarividência: a razão é aquilo que se pode ver claramente, segundo os iluministas. No surrealismo, diferentemente, ocorre uma subversão dos valores, em que poderíamos pensar nas trevas como algo luminoso, já que seriam visíveis, e mais do que isso, trevas como um atrativo para o olhar que ultrapassa seu limite.

Encarar as trevas, atenta Cesariny, é tarefa que exige coragem: "enveredar pela estrada/ Da Coragem/ porque a este respeito - e creio que digo bem -/ nenhuma garantia de leitura grátis/ se oferece ao viandante". "Nenhuma garantia de leitura grátis", enfatizamos as palavras de Cesariny, de modo a colocar no centro da questão a palavra como atividade, em que o deslocamento (patente na imagem do "viandante") e importa pensar no deslocamento como mobilidade da própria subjetividade - é condição necessária.

A segunda parte do poema é predominantemente afirmativa - "Haverá uma idade para nomes que não estes/ haverá uma idade para nomes/puros" - ainda que essa afirmação seja deslocada temporalmente, isto é, ainda que incida sobre o futuro (o surrealismo como uma utopia?). É mesmo o nome que se mantém em evidência e, aqui, já não se trata somente do nome próprio, da busca do sujeito, do cerceamento identitário: tudo se confunde, trata-se da pureza, a mesma pureza que é qualidade 
daquilo que sabe filtrar, mas que estabelece um elo de afinidade para o qual todos os nomes devem convergir. Trata-se de um nome, de muitos nomes "que façam irromper nos nervos e nos ossos/ dos amantes/ inexplicáveis construções radiosas/ prontas a circular entre a fuligem/ de duas bocas/ puras": nomes capazes de mobilizar o cordão de comunicação sensitiva entre as partes todas do corpo (nervos), capazes de mobilizar a estrutura de sustentação dos corpos (ossos) - num procedimento simultâneo de sensibilização e estruturação - com especial ênfase para o fato de que "as bocas" dos amantes, ao pronunciá-los, pudessem romper com a fuligem que se interpõe entre os dois corpos. A ação da palavra futura é descrita mediante uma metáfora propriamente mecânica.

$\mathrm{Na}$ estrofe subsequente em que se dirige, pela primeira e única vez, a Artaud, “ó único mestre vivo" (e, tendo Artaud morrido em 1948, só é possível falar na vida que pulsa no corpo de suas palavras por extensão à sua pessoa), há novamente uma sequência de recusas, que, entretanto, neste momento, parecem resultar de um embate contra as soluções únicas e definitivas: “Ah não será o esperma torrencial diuturno/ nem a loucura dos sábios nem a razão de ninguém", será, poderíamos sugerir, todas as coisas em conjunto, desde que nomeadas translucidamente, desde que "(...) esquecidos por completo/ os grandes nomes opacos que hoje damos às coisas", e recorremos novamente à qualidade da transparência (recusa da opacidade), como possibilidade que a matéria possui de ultrapassar seus limites pela permeabilidade da visão. "Não será mesmo quem sabe (...)/ o fim da pavorosa dança dos corpos", de modo que no desejo de continuidade da "pavorosa dança dos corpos" estaria toda a esperança da revolução surrealista, conforme bem formulou Artaud em "O teatro e a ciência":

Tratava-se duma revolução e não há ninguém que não apele para uma revolução necessária,

mas não sei se muitos terão pensado que uma tal revolução não será verdadeira enquanto não for fisicamente e materialmente completa,

enquanto não se voltar para o homem,

para o próprio corpo do homem

e não se decidir enfim a pedir-lhe 
que $_{\text {mude. }}{ }^{254}$

Toda essa revolução no corpo do sujeito, na sua potencialidade de ação se deve, portanto, a uma revolução dos nomes, como bem aponta Ana Kiffer a respeito de Aratud: “Artaud singulariza em sua trajetória o entrelaçamento entre poesia, linguagem e pensamento através do corpo. Seria o corpo o locus da 'crise' e da 'crítica' de Artaud." 255 , e se torna difícil estabelecer em que medida o sujeito é causador dela, e os nomes, a sua consequência. Ou vice-versa. Essa dificuldade, acreditamos, se deve à multiplicidade de fatores envolvidos numa proposta que, como foi a proposta surrealista, abarca a ideia de humanidade mesma, sendo, portanto, de uma amplitude imensurável; de forma que seria mais adequado pensar, na esteira das análises interpretativas que desenvolvemos, que há um desejo de coincidência entre o sujeito e o(s) nome(s), exatamente como parece coincidir vida e obra na defesa do surrealismo como modo de existir. No limite, "Trata-se de devolver à linguagem um estatuto de corporeidade" 256 , entretanto, trata-se de mais, uma vez que "(...) os corpos não se esgotam sobre o plano que os concebemos, permanece, portanto, a necessidade de refazê-los." ${ }^{257}$, mediante uma veemente contestação do humanismo burguês, há a negação do homem - tal como humanisticamente concebido - para que seja possível uma reconsideração da vida sensível ${ }^{258}$, de modo que refazer os corpos torna-se sinônimo de refazer a linguagem, exatamente como neste post-scriptum que Artaud acrescenta a "Para acabar com o julgamento de Deus" (texto escrito no ano de sua morte, 1948, com a finalidade de uma leitura radiofônica):

Quem sou eu?

De onde venho?

Sou Antonin Artaud

\footnotetext{
${ }^{254}$ ARTAUD, Antonin. “O teatro e a ciência” In: Antologia Pirâmide, no 1, Lisboa: fevereiro de 1959, p. 6-9.

${ }^{255}$ KIFFER, Ana. Antonin Artaud, uma poética do pensamento. A Coruña: VEGAP, 2003, p. 15.

${ }^{256}$ Idem, p. 195.

${ }^{257}$ Idem, p. 58.

${ }^{258}$ Para uma reflexão empenhada acerca das relações do corpo com o surrealismo e derivações criativas (notadamente sobre expoentes franceses): Cf. MORAES, Eliane Robert. O corpo impossível. São Paulo: Iluminuras: 2005, p. 88.
} 
e basta eu dizê-lo

como só eu sei dizer

e imediatamente

verão meu corpo atual

voar em pedaços

e se juntar

sob dez mil aspectos

a um novo corpo

no qual nunca mais

poderão

me esquecer ${ }^{259}$

Nestes versos nota-se o mesmo empenho em relação ao nome próprio, ao corpo e à linguagem, que notamos em Cesariny (de certo, não coindidentemente...): o "só eu sei dizer" (ou o dizer surrealista) capaz de multiplicar o corpo próprio em pedaços até que estes se juntem a um novo corpo, um corpo outro. Aqui a (meta)linguagem como propulsora da matéria subjetiva em vias da alteridade, ou ainda, a alteridade como um dos modos de supor uma subjetividade não identitária, isto é, não una, mas multiplicada e direcionada ao exterior.

Retomando o poema de Cesariny, importa dizer que os dois versos conclusivos merecem ainda atenção, uma vez que podem provocar uma quebra de expectativa no leitor que se coloca perante um poema surrealista: "Haverá/ um acordar". O surrealismo exaltou o inconsciente e a sua manifestação através do sonho, de forma que dormir é um dos modos mais eficazes de acessar o inconsciente. A expectativa do sujeito do poema, ao recair sobre a ação contrária (acordar), faz apenas ocultar - mas não elimina -, a relação implicada entre o acesso ao inconsciente (dormir), e ação que deve decorrer deste acesso (acordar), de forma que somente a vida vivida fora do sono pode materializar em ação aquilo que no inconsciente é apenas o seu avesso: metafísica. Como dissemos nas notas introdutórias, não acreditamos ser possível pensar os surrealismos todos, sem que se considere a sua metafísica fundadora: $o$ inconsciente (no que dele é devido a parcela de psique, uma vez que o soma também

\footnotetext{
${ }^{259}$ ARATAUD, Antonin. Escritos de Antonin Artaud (tradução, seleção e notas: Claudio Willer). São Paulo: L\&PM, 1983, p. 146.
} 
age no inconsciente ${ }^{260}$ ) fonte dos muitos mistérios e possiblidade das almejadas transformações. A psicanálise foi, sem dúvida, a grande disparadora de uma nova maneira de encenar os mistérios da humanidade e muito bem apropriada pelos surrealistas, como bem enfatiza Maria Inês França:

(...) tal como na prática-teórica psicanalítica, também na arte [surrealista] é de extrema importância a experiência onírica, em que o valor da imagem se apresenta subvertido, tal como Freud havia demonstrado, pois não mais ligado ao seu significado e sim remetendo à sua decifração, à diferença entre realidade psíquica e o real substantivo. ${ }^{261}$

Na prática surrealista, a realidade psíquica parece visar materializar-se em ação transformadora no real substantivo. É de se notar que mesmo Freud chegou a defender que as categorias psicológicas por ele estabelecidas (categorias metafísicas, se excluirmos o aspecto sensorial de que se compõe), um dia seriam substituídas por categorias químico/fisiológicas ${ }^{262}$, como ele expressou na seguinte passagem de Introdução ao Narcisismo I : “(...) é preciso não esquecer que todas as nossas concepções provisórias em psicologia devem ser, um dia, baseadas em alicerces orgânicos. $" 263$. Sem pretender, mediante essa citação, uma defesa do materialismo como justificativa onipotente, trata-se apenas de orientar a leitura para que o corpo e suas ações assumam o lugar de destaque que lhe cabe na poesia em questão.

Coincidência, coexistência, convergência, participação, extensão da subjetividade são modos de abordagem inescapáveis para se pensar a relação entre vida

${ }^{260}$ Para uma explicação mais detalhada da combinação entre os componentes orgânicos e as representações mentais vale consultar: FREUD, S. "Os estímulos e as Fontes dos Sonhos" In: $A$ interpretação dos sonhos. Rio de Janeiro: Imago Editora, 2001, p. 41-60, em que Freud mostra a influência dos estímulos sensoriais externos e internos como fatores que, juntamente com as fontes psíquicas, contribuem para a elaboração onírica; e ainda: FREUD, S. "O inconsciente" In: Escritos sobre a Psicologia do Inconsciente. Rio de Janeiro: Imago, 2006, p. 13-74, especialmente os tópicos "Sentimentos inconscientes" e "Palavra e objeto", em que essa relação psique e soma aparece evidenciada.

${ }^{261}$ FRANÇA, Maria Inês. "Fascinação: o olhar e o objeto no surrealismo e na psicanálise" In: $O$ Surrealismo. (Org. GUINSBURG, J. E LEIRNER, Sheila). São Paulo: Editora Perspectiva, 2008, p. 96.

${ }^{262}$ É fato que o desenvolvimento posterior da psicanálise parece ter abdicado dessa via de solução possível que, entretanto, ficou a cargo da psiquiatria. De qualquer modo, importa ressaltar que a expectativa de uma solução fisiológica para os problemas psíquicos era nutrida por Freud (ele próprio neurologista de formação), ao mesmo tempo em que desenvolvia suas investigações sobre o inconsciente.

263 FREUD, Sigmund. Obras Completas volume 12: Introdução ao narcisismo, ensaios de metapsicologia e outros textos (1914-1916). Tradução: Paulo César de Souza. São Paulo: Companhia da Letras, 2010, p. 21. 
e obra nesse contexto. Vale ainda retomar algumas palavras de Cesariny, em carta de 1941 a Cruzeiro Seixas (portanto, antes mesmo da aventura surrealista tomar forma): “o poeta não pode fugir a si próprio (...) pedir ao poeta que renuncie a si mesmo é como pedir ao vento que faça ouvir uma sinfonia em Ré maior."264, ora, um atestado prévio de que a subjetividade está necessariamente implicada no labor poético - numa clara adesão às relações entre vida e obra -, fato que, após a investida surrealista, passa a ser redimensionado em função dos ideais que norteiam o movimento, que permitem, a partir de então, o estabelecimento de um vínculo intrínseco entre a manifestação criativa e a (re)constituição identitária - sem que se entenda "identidade" como algo fixo e imutável. Trazemos, então, um poema, intitulado, homonimamente, "poema",265, transcrito a partir da mesma terceira edição de Pena Capital:

poema

Reconheço este quarto impermeável

reconheço-te estás adormecido

o peito muito aberto as mãos luminosas

o grande talento dos teus dentes miúdos

Há o perigo de um grito lindíssimo

quando andas assim comigo no invisível

Quando a manhã vier sairás comigo

para o espaço que nos falta para o amor

que nos falta

A aurora

está fatigada

a aurora

${ }^{264}$ CESARINY, Mário. Cartas de Mário Cesariny para Cruzeiro Seixas. (Org.: Perfecto E. Cuadrado, António Gonçalves, Cristina Guerra). Lisboa: Assírio \& Alvim (Documenta), 2014, p. 30.

${ }^{265}$ CESARINY, Mário. Pena Capital. Lisboa: Assírio \& Alvim, 2004, pp. 42, 43. 
como um rio nosso

em torno dos elevadores

Tinha eu a idade

de um marselhês

silencioso

$$
\text { e tímido }
$$

Tu davas-me a lousa dos magos

o teu riso as letras

mais obscuras do alfabeto

Foi há muito tempo

ou agora

na caverna dos leões expressivos

A caverna que dá para a caverna

a caverna os lagos diligentes

Belo tu és belo

como um grande espaço cirúrgico

Porque tu não tens nome existes

A minha boca

sabe à tua boca

A minha boca

perdeu a memória

não pode falar as palavras

entram no seu túnel

e não é preciso segui-las

Disse que és alto

alto 
branco e despovoado

É o aspecto metalinguístico que norteia nossa leitura. Metalinguístico, já que supomos que o destinatário do poema, o "tu" que aqui figura, seria o próprio poema. Para calçar esta proposta de leitura, seguem as reflexões de Josette ReyDebove: « (...) poème, suivi d'un poème est dans la même situations que mot suivi d'un mot; il classe ce qu'il présente, au moyen d'un nom commun métalinguistique, poème, et s'il le dénomme avec plus de précision, c'est un 'nom propre métalinguistique de parole' ». ${ }^{266}$. Pertinente, neste caso, seria embaçar de tal modo as fronteiras entre matéria/corpo e linguagem, que apenas um poema cujo "peito muito aberto", as "mãos luminosas", um poema possuidor de "dentes miúdos" e de "grande talento" poderia dizer-se a si mesmo, além de dizer-se ao sujeito da escrita.

O espaço da intimidade é de pronto demarcado: "este quarto impermeável", que, paradoxalmente, é tornado permeável mediante a atualização do poema, pela ação própria aos leitores. O quarto, vale dizer, é ainda o espaço onde o amor acontece e, se dissemos que o destinatário do poema seria o próprio poema, assim personificado mediante o peito, as mãos, os dentes - encarnado, portanto -, dizemos então que o poema e o sujeito a quem se destina o amor coincidem: o poema é o sujeito do amor, é quem, adormecido, partilha da experiência do invisível (novamente, propomos, o invisível como o que está para além dos sentidos, em possível remissão ao inconsciente com a sua face metafísica, e o dizemos, uma vez que o quarto é também o espaço do sono), e dessa experiência surge "o perigo de um grito lindíssimo", um espasmo de amor que almeja a manhã, este tempo que possibilita que o amor ocupe os espaços que se situam fora da intimidade - mais uma vez, obedecendo à proposta interpretativa do poema anterior, em que "acordar" e, portanto, transformar em ato as imagens oníricas, parecia ser a grande expectativa do sujeito. A "aurora", no entanto, "está fatigada", talvez porque o amanhecer é luta diária que exige do amor a força para a expansão do amor surrealista em direção aos espaços públicos. A imagem do rio em torno dos elevadores sugere essa espécie de movimento (movimento das águas) que, entretanto não consegue ascender, apenas circunda o objeto dotado do poder da elevação, o que sugere uma espécie de desencanto, reiterado adiante nos versos: "A minha boca/ perdeu a memória/ não pode falar as palavras/ entram no seu túnel/ e não é preciso

${ }^{266}$ REY-DEBOVE, Josette. Le metalangage. Montréal: Le Robert, 1986, p. 274. 
segui-las", o túnel da memória, por onde se perdem as palavras das quais o sujeito parece abdicar, numa espécie de sonambulismo diante do passado (atenção ao fato de que a memória é qualidade da boca, de modo que a percepção sensorial não é subjacente aos mecanismos da mente, mas coincide com ela, exatamente na esteira fenomenológica). O passado, por outro lado, é o momento em que, com a idade de um "marselhês silencioso e tímido" o sujeito recebia do poema, "a lousa dos magos/ o teu [do poema] riso as letras/ mais obscuras do alfabeto". Ora, a obscuridade das letras, bem como a remissão à magia, nos remetem novamente para o aspecto metafísico da abordagem surrealista. Irrecusável como viés de análise, como dissemos em outro momento em relação ao inconsciente, a metafísica aparece aqui como correlato das palavras perdidas no túnel da memória e, a despeito de que não seria preciso segui-las, como lemos em outro verso, importa ressaltar o fato de que mediante ela é que se manifesta o sorriso (carne) do poema. Parece estar em questão, um movimento que vem da metafísica em direção à física. Em outras palavras, somos conduzidos por um caminho que vai das letras mais obscuras na lousa dos magos ${ }^{267}$, à boca do poeta/poema: "A minha boca/ sabe à tua boca", de modo que a sabedoria ocorre mesmo na carne do sujeito que, como viemos demonstrando, se confunde com a carne do poema. Assim como em Herberto Helder, a boca é evidenciada na esteira da nossa leitura metalinguística: é nela que se dá o ofício da palavra.

Daí que a recorrência da imagem da caverna pode ser lida nesse jogo entre claro e escuro que o poema encena: é na caverna, local de pouca luz, que habitam os "leões expressivos", animais selvagens, de grande força e vigor, aqui, dotados de capacidades expressivas. O leão como símbolo das forças incontidas, expressivo como deve ser um poema. Se pensado em relação à pouca luz que nele incide (pois habita a caverna), é como se urgisse um esforço para poder enxergá-lo, há que ir buscá-lo, há que mobilizar os sentidos para poder acessar esse instinto supremo de que o leão é representante na natureza. Também associados à caverna, estão os "lagos diligentes", águas, como já apareceram nos versos anteriores, cujas propriedades são a mobilidade e a transparência (novamente atentamos para a transparência como uma forma de expansão da matéria pela acessibilidade do olhar que a atravessa, novamente a percepção sensível como forma de recolocar o sujeito na fronteira do corpo próprio -

\footnotetext{
${ }^{267}$ De acordo com a etimologia traçada no Houaiss, temos que "lat. măgus, $i$ 'mago, sacerdote entre os iranianos', do gr. mágos,ou, segundo Heródoto, 'sacerdote persa que interpreta os sonhos"', numa acepção que conflui com a importância que os sonhos adquirem para o surrealismo.
} 
para lançar mão da terminologia fenomenológica - e intensificar a ideia de permeabilidade e mobilidade contra os limites e estratificações da concepção cartesiana), e aqui aparecem qualificadas pelo adjetivo diligentes, isto é, cuidadosas, numa possível complementariedade opositiva à ideia de instinto e força presente na imagem do leão.

"Belo tu és belo/ como um grande espaço cirúrgico", a beleza do poema, aqui relacionada ao espaço das atividades manuais sobre o corpo, à minúcia e à precisão requeridas nessa atividade; que se notam, em especial, na composição deste poema, em que a disposição dos vocábulos no verso, os espaçamentos, bem como as quebras estróficas, revelam grande precisão na manipulação das palavras, nos modos de colocá-las em relação. Mais além, o belo em evidência, que nos remete a um momento da produção de Cesariny anterior mesmo ao surrealismo, em que afirma: “O belo, a minha noção do belo, às vezes, ajuda-me. Há sempre possibilidades para continuar."268. Trata-se de um trecho de uma carta remetida a primeiro de janeiro de mil novecentos e quarenta e três ao companheiro Cruzeiro Seixas, em que podemos notar o belo como sustentáculo de uma percepção direcionada esteticamente (considerado estético, toda manifestação sensorial da linguagem - seja ela verbal, visual ou sonora - que revoluciona a percepção de mundo convencional, fixada culturalmente).

A seguir, lemos que a ausência do nome não indica, entretanto, a ausência da existência: "Porque tu não tens nome existes", e nos versos subsequentes, somos avisados de que a boca do sujeito perdeu a memória, não pode falar as palavras, porém, é na boca do poema, isto é, na existência do poema (palavras...) que o sujeito sabe a boca própria (existência própria), como vimos há poucas linhas. Ora, parece manter-se aqui essa oscilação entre claro e escuro no que se refere à possibilidade de coexistir em relação ao poema. Não há plenitude (o surrealismo, e mais, o amor surrealista permanece uma busca, uma meta que direciona a ação), tampouco há desistência: existir é tarefa que exige uma auto-reelaboração constante, poderíamos supor, a busca pelo nome permanece, em confluência com o poema lido anteriormente. Também em confluência com o poema anterior lemos os últimos versos, "Disse que és alto/ alto/ branco e despovoado", o poema alto, talvez pela possibilidade de ascensão, branco como signo da pureza (possivelmente em alusão à página, suporte do poema) e

\footnotetext{
${ }^{268}$ CESARINY, Mário. Cartas de Mário Cesariny para Cruzeiro Seixas. (Org.: Perfecto E. Cuadrado, António Gonçalves, Cristina Guerra). Lisboa: Assírio \& Alvim (Documenta), 2014, p. 50.
} 
despovoado: este último, vocábulo que marca, mais do que qualquer outro, essa espécie de desencanto que flagramos nos versos anteriores, ao mesmo tempo que incita o seu oposto, em outras palavras, é como se, dormente ainda, houvesse esse ímpeto de povoar o poema, de habitá-lo, de existi-lo como parece ter sido possível em algum passado não definido.

Essa aspiração pelo nome próprio que flagramos em "a antonin artaud", aqui permanece, e passa a ser uma busca pelos nomes de maneira geral, nomes capazes de atualizar o amor, a existência - pelo projeto de existir em revolução, movimento e transparência que foi o surrealismo. É exatamente nesse agir (a escrita, a linguagem) com aspirações revolucionárias, que a vida vai ganhando contornos e confundindo-se com o dizer de si: o poema ${ }^{269}$. Essa atuação/existência, tal como o surrealismo em suas mais amplas pretensões, permanece, entretanto, incompleta, daí o tom desencantado que flagramos em alguns versos, em outros um tom prospectivo. $\mathrm{O}$ que merece ser ressaltado é que o sujeito se apresenta em constante mobilidade (o que se faz sentir no corpo), os contornos subjetivos, sempre flexíveis, se confundem com o processo de busca pela escrita, e isso implica nas caminhadas pelos espaços, nos trânsitos pelos tempos, nas visitas em direção à alteridade: eis o seu agir, um verbo que não para de se metamorfosear.

\footnotetext{
${ }^{269}$ Motivado pela leitura de "homenagem a cesário verde", "a antonin artaud" e "you are welcome to elsinore”, Manuel Gusmão fala da importância da palavra na obra de Cesariny: “(...) as palavras deixam de ser tomadas como meros instrumentos de comunicação, como pura organização simbólica, é por estas palavras que temos acesso ao imaginário e podemos tocar o Impossível." (GUSMÃO, Manuel. "Entre nós e as palavras (Mário Cesariny)" In: Tatuagem e palimpsesto. Lisboa: Assírio \& Alvim, 2010, p. 400), e ainda: “O poema é uma arte poética que se mostra no uso que faz das palavras no poema, ora lançando-as como imagens (nas quais se mudássemos as palavras mudaríamos de imagem), ora invocando-as nessa sua condição de palavras-que-alucinatoriamente-dão-a-ver.” (Idem, p. 406).
} 


\subsection{Cruzeiro Seixas e o nome espantoso}

Em continuação à proposta de atentar para o nome e suas implicações no corpo - proposta que que se delineou como um eixo de importância para se pensar o sujeito da escrita mediante a escolha dos poemas precedentes, selecionamos o seguinte poema de Cruzeiro Seixas para leitura:

O meu nome é um corpo quente interiormente cheio de astros de que são pavimentadas estas estradas.

Espero pelo meu nome altas horas da noite e sinto-o inquieto rondar a cidade.

Olha a sua própria estátua e não se reconhece.

À falta de outro alimento devora seus próprios cabelos roubando-os ao Vento.

O meu nome é bicéfalo.

Guarda no peito um sinal que aponta a todos os sexos.

Quando enfim ele roda a fechadura eu saio pela janela porque meu nome tem as mãos sujas de sangue.

De outras noites antigas sei que tem na carteira coloridas paisagens de guerra - não das guerras das feras mas das guerras dos homens.

Os anjos dormem;

Mas depois vêm resolutamente até mim

enquanto lá fora

tudo se cobre da brancura excessiva da luz. 
Áfricas, $56^{270}$

O primeiro verso do poema, "O meu nome é um corpo quente", remete imediatamente para o título do primeiro livro de poemas de Cruzeiro Seixas: Eu falo em chamas $^{271}$, de 1986. Nos dois casos a (con)fusão do corpo com a palavra metalinguística é identificada com o erotismo, seja pela definição do nome como um "corpo quente", seja ainda pela dupla acepção do vocábulo "falo": forma verbal em primeira pessoa do singular e substantivo - órgão sexual masculino - qualificado pela chama, metáfora do desejo sexual. Nos dois casos o contorno subjetivo se dá a ver pelo ato da escrita (a fala do poeta...) e pela maneira como o corpo está presente na elaboração deste sujeito: o corpo do desejo. Nos versos subsequentes, temos que os corpos celestes povoam o interior deste nome-corpo, ao mesmo tempo em que constituem o pavimento das estradas: há aqui um paralelismo que abarca os opostos posicionais, o alto e o baixo (céu, chão) e o interno e o externo (corpo, estradas). Essa amplitude espacial catalisada na imagem do nome-corpo aponta para o mesmo princípio de extensão que notamos no caso de Cesariny, o que permite considerar o surrealismo (elo entre os dois poetas) como um força expansiva, que busca alcançar os espaços de fora, reiterando a proposta fenomenológica de fusão entre mundo subjetivo e mundo objetivo. Nesse momento, a fusão não ocorre entre corpo próprio e corpo alheio, mas entre corpo próprio e espaço, no sentido mesmo do ser em situação do qual

\footnotetext{
${ }^{270}$ Este poema, datado de 56, conforme indicação, consta no volume I de sua Obra Poética editada por Isabel Meyrelles (SEIXAS, Cruzeiro. Obra Poética (vol. I). Quasi Edições: Vila Nova de Famalicão, 2002, p. 183). No volume III, nos deparamos com a seguinte variação, já não em versos, intitulada DIÁRIO DE 957: "O meu nome é um corpo cheio de astros, dos astros com que são calcetadas as estradas. [§] Espero pelo meu nome altas horas da noite, e sinto-o rondar a cidade. Rodeia a sua própria estátua, chicoteia-a com seus próprios cabelos, devora as pedras mais próximas da base, à falta de outro alimento. [§] O meu nome é bicéfalo; tem no peito um sinal cujo significado esqueci. $O$ meu nome tem em si todos os sexos. [§] Regressa. Quando roda a fechadura sou eu que salto pela janela - que o meu nome traz as mãos sujas de lama de sangue. Sei que traz na carteira coloridas paisagens de guerras, não das dos homens mas sim das feras... [§] Oh vem, vem mansamente, que sou eu que te espero coberto de guerras. Lá fora faz frio, neva." (SEIXAS, Cruzeiro. Obra Poética (vol. III). Quasi Edições: Vila Nova de Famalicão, 2004, p. 433). O título da versão transcrita supõe que esta seria posterior à versão versificada, e poderíamos aceitá-lo, não fosse dois fatos que bagunçam, por assim dizer, a nossa tentativa de demarcação temporal: um diário supõe que a escrita seja criação simultânea ao momento indicado (57), o que nos levaria a crer que esta prosa é anterior ao poema datado de 56, de modo que as datas não confirmam a suposição...; há ainda uma advertência do Cruzeiro Seixas que lemos num outro livro de poemas que diz o seguinte: "São fictícias as datas dos poemas, na intenção de fugir à académica mania de situar no tempo as obras; para mim tudo foi feito ontem, a Vitória de Samotracia, Ucello, o Benin, aquele cão de Goya a aterrar-se nas areias movediças, etc etc etc." (SEIXAS, Cruzeiro. Viagem sem regresso. Lisboa: Edição Tiragem Limitada, 2001, p. 137.). Portanto, mais do que situar temporalmente o poema e o texto em prosa, importa pensar algumas variações que eles apresentam, $o$ que faremos ao longo da nossa leitura.
}

${ }^{271}$ SEIXAS, Cruzeiro. Eu falo em chamas. Guimarães: Galeria Gilde, 1986. 
nos fala Merleau-Ponty.

Importa atentar para sugestão explícita no vocábulo "estradas": os caminhos percorridos pelo sujeito da escrita, a um só tempo, constituem o nome-corpo e são constituídos por ele. A ideia de mobilidade é reiterada pelos versos seguintes, em que um novo dado surge como complexificador dessa subjetividade: "Espero pelo meu nome altas horas da noite/ e sinto-o inquieto rondar a cidade.”; ora, há uma cisão implicada na distinção gramatical entre o sujeito da enunciação (o "eu" que espera) e o objeto da espera ("meu nome"), que irá se acentuar alguns versos adiante, quando lemos: "Quando enfim ele roda a fechadura eu saio pela janela", de modo que quando o nome ("ele") entra pela porta, o sujeito ("eu") sai pela janela, sequer se cruzam, não coincidem nem mesmo na pessoa do discurso. Essa cisão implica um movimento complementar ao que descrevemos acima, quando propusemos que haveria uma expansão do interior ao exterior: aqui, o movimento contrário é que se evidencia, uma vez que o nome próprio é ele mesmo externo ao sujeito, a alteridade é condição necessária da identidade, dizer "eu" é uma das faces de dizer "ele" e vice-versa. Em outro contexto, Cruzeiro Seixas se pronuncia:

Mas eu não sou verdadeiramente o Cruzeiro Seixas, sou um representante dele. Esse por certo não visitaria só aos 45 anos os museus do Prado ou do Louvre, não ficaria preso na intrigalhada desse meio abjecto (...) quero assumir minha solidão, a distância a que fiquei do amor sublime, que acima de tudo desejei. ${ }^{272}$

Essa duplicidade que flagramos no poema é reiterada no seguinte verso: "O meu nome é bicéfalo", em que o termo (bi)céfalo, em referência ao crânio, pode ser lido também como uma referência ao sexo, não apenas por uma espécie de "contaminação" operada pelos versos imediatamente subsequentes ("Guarda no peito um sinal/ que aponta para todos os sexos"), mas também por conter em si, anagramaticamente, a palavra "falo" - que, nessa cadeia interpretativa, pode ser lida como uma multiplicação do sujeito (ou duplicação, em exatidão significativa com respeito ao prefixo bi-), que passa necessariamente pelo corpo, seja o corpo do discurso (o cérebro ou a fala/ "falo"), seja o "corpo quente" do amor erótico. Cabe ainda uma aproximação com as exaustivas figurações do acéfalo empenhadas pelas

\footnotetext{
${ }^{272}$ SEIXAS, Cruzeiro. "Entrevista" In: Revista ENTRE, Lisboa: $\mathrm{n}^{\mathrm{o}}$ 5, p.56-71, 2014, inverno de 2014, p. 78. Importa dizer que tal pronunciamento parece marcar uma distância considerável entre o sujeito do desejo - o sujeito surrealista - , e o sujeito das possibilidades - o sujeito realista, ou o sujeito diante dos limites impostos pelo real - de modo que o surrealismo, tal como esboçamos no caso de Cesariny, se afigura mais uma vez como um ideal, uma meta a se perseguir, jamais existe como ponto de chegada
} 
vanguardas européias do começo do século XX, conforme apresenta Eliane Robert Moraes: “(...) o acéfalo moderno parece representar não só aquilo que lhe falta, mas também, e principalmente, o excesso possibilitado por essa ausência."273, ou, nas palavras de Georges Bataille: "a única sociedade repleta de vida e força, a única sociedade livre é a sociedade bi e policéfala que confere aos antagonismos fundamentais da vida uma saída explosiva constante" ${ }^{274}$. Daí a saída pela qual Cruzeiro Seixas conseguiria escapar à lógica identitária da coerência unitária e do princípio de não-contradição. Saída, sem dúvida, viabilizada pelo sujeito do desejo acima referido, que mediante a percepção possibilitada pela operação da linguagem (composição poética), se torna capaz de se recompor a si próprio a partir da escrita.

Se lido em referência ao crâneo, como consta no dicionário, o termo "bicéfalo" nos remete de pronto a um outro pequeno poema em que lemos:

É lógico?

Não

é biológico

- quer dizer

duas vezes lógico.

África $58^{275}$

Numa proposta de junção de leitura entre o vocábulo em questão e o pequeno poema acima, arriscaríamos dizer que "bicéfalo", seria, portanto, um correlato de "biológico", não apenas porque remete ao crâneo/cérebro e, por consequência, à estruturação e ao funcionamento do organismo (exercícios próprios à biologia), mas com mais ênfase -, porque remete a um engajamento muito próprio aos surrealistas: a recusa da lógica como modo de condução da percepção e organização subjetiva. Essa recusa se faz ver no pequeno poema mediante a ressignificação do termo biológico, resultado de um trocadilho que pressupõe como prefixo o morfema bi- que daria um sentido de duplicidade ao termo "lógico", de modo que este teria sua significação expandida ou aumentada, se entendido, diversamente, como "biológico". Ou seja: o

\footnotetext{
${ }^{273}$ MORAES, Eliane Robert. O corpo impossivel. São Paulo: Iluminuras: 2005, p. 184.

${ }^{274}$ BATAILLE, Georges Apud MORAES, Eliane Robert. O corpo impossivel. São Paulo: Iluminuras: 2005, p. 187.

${ }^{275}$ SEIXAS, Cruzeiro. Obra Poética (vol. III). Quasi Edições: Vila Nova de Famalicão, 2004, p. 286.
} 
biológico, seria mais significativo do que o lógico, no sentido mesmo em que há mais biologia do que haveria lógica no ser, ou naquilo que "É", para retomar o primeiro verso do poema. Sobre este primeiro verso, poderíamos dizer que a ocultação do sujeito não o oculta de fato, mas faz com que ele seja evidenciado pelo próprio verbo que o supõe: o sujeito se manifesta, de algum modo, no verbo ser que demarca a sua existência. A ideia do trocadilho que Cruzeiro Seixas propõe em relação ao prefixo não elimina, entretanto, o sentido primeiro de "bio" (vida), ao contrário, apenas acrescenta significações, de modo que a própria noção de vida é ressignificada mediante tal jogo de combinações semântico-morfológicas.

A correlação entre os termos "bicéfalo" e "biológico" se estabelece, portanto, já que ambos os vocábulos apontam para uma desconstrução da lógica como leitura de mundo, já que está implícita a recusa de uma via única constitutiva do sujeito (mediante uma reelaboração perceptiva desencadeada pelos jogos de linguagem). No caso de "bicéfalo", a desconstrução se dá pela ideia de uma subjetividade dividida (em que estão implicados, vale insistir, tanto a sexualidade, quanto o cérebro ou crâneo, em sua dimensão corpórea), em contraposição à unidade presente na ideia do sujeito racionalista, em que, o "eu" absoluto é completamente autônomo - em termos de atestado de existência -, em relação ao "ele", ao outro; no caso de "biológico", a desconstrução ocorre, como é evidente - e reiteramos -, pela prioridade do corpo em detrimento do pensamento enquanto entidade metafísica.

Retomando o tópico da mobilidade do sujeito, temos que identidade e alteridade figuram, portanto, como polos complementares e o percurso de um a outro ocorre nas duas direções: de dentro para fora e de fora para dentro, de modo que poderíamos pensar que este sujeito, este nome-corpo, é, de fato, um movimento, cujas saídas e entradas são propriamente a sua definição. Daí que ele "Olha a sua própria estátua/ e não se reconhece.”, pois não poderia mesmo se reconhecer num objeto tão estático com formas severamente delimitadas.

Ora, se je est un autre ${ }^{276}$, como já havia formulado Rimbaud, eu e outro são obviamente coincidentes, de modo que só resta ao sujeito a autofagia, ou seja, "outro alimento" irá sempre faltar, uma vez que o alimento, ou tudo que possa ser alimento (outro, objeto exterior ao sujeito), se confunde consigo mesmo. Mais uma vez, importa retomar a ideia de Merleau-Ponty, quando afirma a flexibilidade entre eu-sujeito e

${ }^{276}$ RIMBAUD, Arthur. Euvres completes. Paris: Édition Le Livre de poche, 1999, p. 237. 
outro-objeto, chegando mesmo a subverter a ideia de que o outro seria percebido pelo sujeito da percepção como objeto: mais coerente, nesse caso, seria pensar um canal de abertura em que o outro é parte constituinte do eu, exatamente como propõe Cruzeiro Seixas ao complicar essa fronteira. Curioso observar que o outro, em Cruzeiro Seixas, aparece sempre atravessado pelo signo do duplo, o que, numa leitura apressada, poderia sugerir uma restrição da ideia abarcada pelo índice dois, isto é, o sujeito romperia com a sua unidade para alcançar ou transitar pela "binariedade". Propomos, diferentemente, que a significação do "outro" aponta, não para a ideia de um outro, de um outro indivíduo (ou como consta numa das acepções do Houaiss: "o segundo entre dois"), mas para a ideia de todos os outros, de forma que "todos" ou "tudo", seria o correlato significativo mais adequado para se pensar a noção de alteridade como aqui se coloca. E assim afirmamos com base na leitura inicial do poema, em que a situação posicional do sujeito comporta os diversos espaços como componentes identitários.

Lemos há pouco o verso: "Quando enfim ele roda a fechadura eu saio pela janela" e, agora, respeitando a continuidade, temos o verso subsequente: "porque meu nome tem as mãos sujas de sangue.”. A metáfora do crime praticado pelo corpo (mãos) e investido contra o corpo (sangue), ressoa num dado que nos parece oportuno: no já referido catálogo da exposição de Cruzeiro Seixas na Galeria de arte Moderna entre maio e junho de $1982^{277}$, Eurico Gonçalves informa: "a imagem" - retirada de um longo poema, Flash, que Herberto Helder dedica a Cruzeiro Seixas ${ }^{278}$ - " que Cruzeiro Seixas me mostra e com a qual se sente terrivelmente identificado: 'QUASE MORRO DE MEDO AO SENTIR O MEU NOME",279.

De que modo ler o medo advindo do nome? O nome que faz ver o sangue nas mãos; a mão, parte do corpo encarregada da escrita; o sangue, interior do corpo que se expõe (exatamente como lemos em Herberto Helder, em que supusemos a exposição escritural como uma ferida); o nome, corpo sensorial que provoca medo. Com Herberto Helder, Cruzeiro Seixas (se) identifica que sentir o nome é algo que quase provoca a morte ("quase morro de medo...") e, vale aqui, conferir especial atenção para o vocábulo "sentir" que redunda numa acepção sinestésica, já que pode comportar todos os sentidos da percepção. Isto é, não apenas a escuta estaria mobilizada, como

\footnotetext{
${ }^{277}$ ANEXO J, p. 264.

${ }^{278}$ Voltaremos a este poema de Herberto Helder no capítulo dedicado à relação intersubjetiva.

${ }^{279}$ GONÇALVES, Eurico. Cartaz da exposição de Cruzeiro Seixas na Galeria de Arte Moderna (28 de maio - 17 de junho de 1982).
} 
seria de se supor, mas também o toque, o gosto, o perfume, a imagem, numa combinação cujo resultado é uma única impressão: o medo, percepção provocada por este nome que é mesmo um corpo capaz de mobilizar os sentidos todos. A ideia do nome-corpo, parece-nos, é a grande metáfora que se mantém nos três poetas, metáfora que não pode ser desfeita, pois que não haveria correspondente na linguagem ordinária (uma vez que esta se ocuparia de dizer aquilo que - amplamente e sem muita precisão - se considera a realidade cultural: um fundo comum de percepções socialmente fixadas). Conforme a critica literária anglo-saxã, "a linguagem poética apresenta certa 'fusão' entre o sentido e os sentidos que a distingue da linguagem não-poética na qual o caráter arbitrário e convencional do signo libera, tanto quanto possível, o sentido do sensível” ${ }^{, 280}$ e, ainda, nessa mesma linhagem:

(...) na linguagem poética, esse par do sentido e dos sentidos tende a produzir um objeto fechado sobre si; à diferença da linguagem ordinária de caráter basicamente referencial, na linguagem poética o signo é looked at e não looked through; em outras palavras, a linguagem, em vez de ser atravessada em direção à realidade, tornase ela mesma "material" (stuff), como o mármore para o escultor. ${ }^{281}$

Nada explicitamos, entretanto, sobre o medo que o nome próprio provoca. Para isso, nos amparamos nas leituras anteriores e focamos a ideia que perpassa tanto Herberto Helder quanto Cesariny, quando lemos que a busca pelo nome implica a dor do sangue, ou, quando a boca (responsável pela pronúncia do nome) é ao mesmo tempo ferida e cura para a ferida, como vimos em Herberto Helder; quando há um caminho necessário e este é a estrada Da Coragem pela qual enveredou Cesariny, que sabia que o nome próprio provocaria calamidades terríveis, tremores de terra. Ora, esse aspecto assombroso do nome próprio pode ainda relacionar-se com outra imagem bastante recorrente na obra de Herberto Helder, conforme trazido no momento de leitura de seus poemas. Trata-se, vale retomar, da escrita como um ato criminoso, e aqui trago outras citações pertinentes para se pensar o sujeito da escrita: "Pode ainda escrever-se por ilusão criminal: às vezes imagina-se que uma palavra conseguirá

\footnotetext{
${ }^{280}$ RICOEUR, Paul. A metáfora viva. São Paulo: Edições Loyola, 2005, p. 319.

${ }^{281}$ Idem, p. 320. (Embora Paul Ricoeur se manifeste em desacordo com essa perspectiva - um objeto fechado sobre si seria inadimíssivel para uma proposta hermenêutica como a sua em que há grande ênfase na arte como processo que abarca o ponto de partida (ato criativo) e o ponto de chegada (ato receptivo) -, a visada apresentada nessa citação me parece bastante adequada especialmente pelo destaque da palavra poética como matéria).
} 
atingir mortalmente o mundo."282, ou: "Há sempre um crime, percebem? Este envolvimento em empresas policiais vai desde o Édipo ao Hamlet"283 (com especial atenção para a menção ao Édipo e ao Hamlet, dois casos em que o crime está intrinsecamente associado ao percurso identitário, seja esse percurso mais evidente, como é o caso de Édipo, em que a descoberta da sua real identidade é associada ao assassinato do pai, seja ele menos evidente, como é o caso de Hamlet, que vai construindo a sua identidade em função do crime que pretende selar a vingança ao pai: o assassinato do tio); ou ainda: "O autobiógrafo é a vítima do seu crime" ${ }^{\text {,284 }}$, em que a relação entre vida e escrita é ela mesma considerada criminosa e, nesse ato, a vítima e o algoz coincidem: são ambos a mesma pessoa do discurso.

Também Cruzeiro Seixas vai mencionar o nome próprio como aquele "que tem na carteira/ coloridas paisagens de guerras". Se pensamos que a decorrência da guerra é aquilo que fora dela seria qualificado como crime (uso de armas de fogo, assassinatos em massa, destruição de cidades...), somos levados a atentar para a moralidade ambígua presente nas guerras e na própria ideia de crime. Tal ambiguidade se faz notar pela expressão "coloridas paisagens de guerra", em que coloridas paisagens expressão que remete à ideia de beleza e de contemplação - contrasta com a ideia que geralmente se faz das guerras, situações horrendas das quais se pretende escapar: a ideia de beleza e de contemplação não é parte do juízo comum a respeito das guerras. Mas, é claro, a ambiguidade em torno da guerra é muito mais complexa do que a cena de horrores associada a ela, e o sabemos mediante os discursos correntes (à exaustão) que a guerra é sempre justificada pela paz que, paradoxalmente, seria a sua consequência almejada.

Todas essas ambiguidades abarcadas pela ideia de crime associado à escrita me permite a retomada de uma noção já mencionada anteriormente: trata-se do phármakon. Ora, pensar a escrita poética como violência, uma vez que ela viola a ordem natural das coisas, é, de algum modo, atentar para a ambiguidade contida nesse remédio/veneno, elemento externo ao corpo e, justamente por isso, de acordo com Platão, a sua face nociva (ou, para dizer com os poetas, criminosa ou guerreira, sanguinária) se daria a ver. Embora Platão, no Fedro, quando associa a escrita ao

\footnotetext{
${ }^{282}$ HELDER, Herberto. Photomaton \& Vox. Lisboa: Assírio \& Alvim, 2006, p. 71.

${ }^{283}$ Idem, p. 129.

${ }^{284}$ HELDER, Herberto. Apresentação do Rosto. Lisboa: Editora Ulisseia, 1968, p. 17.
} 
phármakon, estivesse ocupado em pensar a escrita como um contra apelo à memória e, portanto, um contra apelo à verdade (e também aí a ambiguidade do termo salta aos olhos: a escrita é, de algum modo, a memória deslocada para o papel e, portanto, a escrita é a garantia da memória), as dobras do texto que são evidenciadas pela leitura de Derrida, se adequam perfeitamente à nossa proposta interpretativa. Lemos:

Não é suficiente dizer que a escritura é pensada a partir de tais ou tais oposições dispostas em série. Platão a pensa, e tenta compreendê-la, dominá-la a partir da própria oposição. Para que esses valores contrários (bem/mal, verdadeiro/falso, essência/aparência, dentro/fora, etc.) possam se opor, é preciso que um dos termos seja simplesmente exterior ao outro, isto é, que uma das oposições (dentro/fora) seja desde logo creditada como matriz de toda oposição possível. É preciso que um dos elementos do sistema (ou da série) valha também como possibilidade geral da sistematicidade ou da serialidade. E se se chegasse a pensar que alguma coisa como o phármakon - ou a escritura -, longe de ser dominada por essas oposições, inaugura sua possibilidade sem nelas se deixar compreender; se se chegasse a pensar que é somente a partir de alguma coisa tal como a escritura - ou o phármakon - que se pode anunciar a estranha diferença entre o dentro e fora; se, por conseguinte, se chegasse a pensar que a escritura como phármakon não se deixa simplesmente delimitar um lugar no que ela situa, não se deixa subsumir sob os conceitos que a partir dela se decidem, abandona apenas seu espectro à lógica que só pode querer dominá-la procedendo ainda dela mesma, seria preciso, então, curvar a estranhos o movimento, o que não poderíamos chamar, simplesmente, a lógica ou o discurso. Ainda mais que o que imprudentemente acabamos de nomear espectro não pode mais ser, com a mesma segurança, distinguido da verdade, da realidade, da carne viva, etc. ${ }^{285}$

É justamente na ambiguidade que estaria a solução: a possibilidade da abertura perceptiva, em completo acordo com a proposta fenomenológica. Conforme atesta esse longo parágrafo que achamos por bem transcrever na íntegra, pouco importa, também para os surrealistas ou para uma linhagem de poetas em que a imagem poética se sobrepõe à ideia na poesia - linhagem na qual se inscreve Herberto Helder -, pouco importa, dizíamos, considerar a oposição enquanto tal. Em outras palavras, pensar o mundo a partir do sistema de diferenças e contrastes (como queria Descartes...), impossibilita que o princípio mobilizador do phármakon-escrita seja ativado:

O phármakon é esse suplemento perigoso que entra por arrombamento exatamente naquilo que gostaria de não precisar dele

${ }^{285}$ DERRIDA, Jaques. A farmácia de Platão. São Paulo: Iluminuras, 2005, p. 50-51. 
e que, ao mesmo tempo, se deixa romper, violentar, preencher e substituir, completar pelo próprio rastro que no presente aumenta a si próprio e nisso desaparece. ${ }^{286}$

Prolongando a amplitude de leitura viabilizada pela noção de ambiguidade, lemos os últimos versos do poema em conjunção aos últimos trechos da prosa (conforme apresentamos em nota inicial), em que as variações entre um e outro texto se apresentam de um modo que nos interessa em particular: são contrastantes, opostas. No poema, lemos a seguinte versão: "não das guerras das feras/ mas das guerras dos homens.", e na prosa: "não das dos homens mas sim das feras...". Se lidos em complementariedade, como é a nossa proposta, os termos homens e feras passam a ser sinônimos. Ou melhor, homens e feras seriam seres com significação complementar: de um lado os animais ferozes, isentos de qualquer domesticação, estariam para além das codificações socioculturais, seres amorais, portanto; de outro lado os homens e a civilização, leis de comportamento, instintos reprimidos, moral rígida que ordena, inclusive, o discurso bélico: há também as regras que conduzem a guerra, os limites, os acordos e mesmo os desacordos estão subsumidos a uma lógica de interação prevista por leis e sistemas de alianças, etc. Ora, se não é a guerra, assim colocada entre homens e feras, o eixo mesmo de união entre aquilo que no homem é a sua pulsão instintiva, paixão incontrolável, e os limites impostos pela civilização? Homens e feras, assim aproximados em sua significação, mediante o termo comum: guerra, de modo que essa aproximação evidencia aquilo que nos homens não pode ser domesticado, não está a serviço da razão, de forma que essa pulsão instintiva aparece como um dado que aponta para o fracasso da humanidade enquanto crença na predominância da cultura (se situada ocidentalmente, como convém para o presente propósito, instituída pelo racionalismo) no que se refere à oposição natureza versus cultura.

São os versos/trechos finais, entretanto, que, lidos conjuntamente, se resolvem numa complementariedade (na esteira de como viemos lendo a ambiguidade presente na noção de phármakon) que nos permite pensar a metafísica pelo seu avesso. A metafísica vem (resolutamente?) com a imagem dos anjos, mensageiros do mundo espiritual, elo de comunicação entre Deus e os homens: "Os anjos dormem;/ Mas depois vêm resolutamente até $\mathrm{mim} /$ enquanto lá fora/ tudo se cobre da brancura excessiva da luz.". Ora, se lida pelo avesso, como é a nossa proposta, a imagem dos anjos converte-se na imagem de homens alados - já que é de imagem que se trata -, de

${ }^{286}$ Idem, p. 57. 
modo que a asa seria o excesso de corpo, o ganho, uma espécie de terceiro termo acrescido como resultado das ambiguidades que o nome próprio suscita: guerra-paz, horror-contemplação, entrada-saída (dentro/fora). Especialmente se conjugamos a versão versificada com a versão em prosa: “[§] Oh vem, vem mansamente, que sou eu que te espero coberto de guerras. Lá fora faz frio, neva.", em que o que "vem”, não é chamamento que se direciona aos anjos, mas ao nome mesmo, ao nome próprio: corpo quente (em contraste com o frio e a neve do lado de fora). Essa relação entre os anjos e os nomes - que só é possível mediante essa proposta de leitura conjunta - não exclui, entretanto, um aspecto que se deve à conotação metafísica presente na imagem dos anjos: o qualificativo que a sustenta, isto é, a bondade inerente aos anjos, a ideia de paz associada a eles que, a um só tempo, é intensificada pela "brancura excessiva da luz" (ou pela brancura da "neve" na versão seguinte) e contrastada com o sujeito que espera "coberto de guerras".

Das ambiguidades eleitas como modo de expressão poética, vale trazer ainda este poema que se apresenta como uma reflexão ${ }^{287}$ de interesse para a problemática em questão:

Entre a aparência e a verdade

há qualquer coisa que não é

nem a aparência nem a verdade

e existe.

Falta uma palavra

que foi talvez roubada,

uma das coisas

que os poetas procuram

entre a areia, com os dentes.

${ }^{287}$ Curioso notar a recorrência de poemas "reflexivos" na produção de Cruzeiro Seixas. Este que agora transcrevo, como o anterior, em que lógica e biologia eram colocadas em foco, convivem com outros tantos, dentre os quais, vale destacar os seus "desaforismos", quase todos inéditos (o espólio do poeta encontra-se sob o abrigo da Fundação Cupertino de Miranda em Vila Nova de Famalicão, PT. Uma pequena seleção dos seus "desaforismos" pode ser encontrada na única edição brasileira dedicada ao poeta, organizada por Floriano Martins: Cf. SEIXAS, Cruzeiro. Homenagem à realidade. São Paulo: Escrituras, 2005). Essa recorrência reflexiva, sugerimos, se apresenta como um amparo poético (no sentido mesmo de uma arte poética) que o poeta parece oferecer aos seus leitores, uma vez que, como vimos, a sua militância no surrealismo foi bastante moderada, de modo que estes pequenos direcionamentos de leitura ou reflexões, com os quais nos deparamos, acabam por suprir uma lacuna deixada pelo seu predominante silêncio nos manifestos e outras formas de atividades discursivas tão frequentes entre os surrealistas. 
Exatamente como propõe Merleau-Ponty na citação que trazemos novamente: “(...) não é preciso perguntar-se se nós percebemos verdadeiramente um mundo, é preciso dizer, ao contrário: o mundo é aquilo que nós percebemos" ${ }^{289}$ - embora seja possível sugerir que a verdade se estabeleça, na filosofia de Merleau-Ponty, como resultado do ato perceptivo mesmo (ainda que o filósofo tome o devido cuidado de não se valer do termo "verdade", como já dito em outro momento), isto é, o sentido da percepção como única via possível de acesso ao mundo acaba por nos conduzir à interpretação de que "verdade", para Merleau-Ponty, é a nossa condição perceptiva. Não a verdade cartesiana, vale ressaltar, aquela verdade imutável e atemporal de que também Cruzeiro Seixas desconfia, conforme o poema acima, mas este "entre", caminho de fluxo contínuo em direções diversas. Esta reflexão, se pensada em relação à atividade criativa (como é a proposta de Cruzeiro Seixas, que enfatiza a tarefa de busca como atividade própria aos poetas), redimensiona a percepção no sentido mesmo da elaboração de um mundo promovida por meio da inauguração perceptiva que a poesia instaura. Por um lado a aparência como aquilo que pode ser captado pelos sentidos e também aquilo que possui uma conotação de transitoriedade (já que a aparência se modifica em função das circunstâncias de tempo e espaço) e, por outro lado, a verdade como aquilo que essencialmente é imutável e perene, uma proposição universal, portanto. A difícil conjunção entre aparência e verdade - tal como lemos esta "coisa que não é/ nem a aparência nem a verdade" ou seja, esta "coisa" simultaneamente com propriedades de aparência e de verdade, já que se situa no "entre", este espaço que lemos como uma via em que a comunicação se faz possível não é senão tudo aquilo que a poesia é capaz de atualizar, uma vez que não tem de prestar contas ao postulado da não-contradição, conforme lógica prescreve. Tampouco a percepção está sujeita às leias da lógica, muito embora haja maneiras de condicionar nossa percepção, há, no sentido oposto, maneiras de torna-la inaugural.

O fim do poema permite que retomemos o corpo como eixo de interesse: a ênfase nos dentes sugere, a um só tempo, a ferocidade da busca, bem como sublinha o teor metalinguístico que viemos flagrando ao longo das análises, uma vez que os

\footnotetext{
${ }^{288}$ SEIXAS, Cruzeiro. Obra Poética (vol. II). Quasi Edições: Vila Nova de Famalicão, 2003, p. 123.

${ }^{289}$ Idem, pp, 13, 14.
} 
dentes situam-se no interior da boca e esta, por sua vez, como vimos exaustivamente nas leituras precedentes, é a parte do corpo responsável pela pronúncia da palavra. Não creio que seria excessivo afirmar, portanto, que a boca ("poro monstruoso que respira o mundo", como formulou Herberto Helder) seria a metáfora dessa subjetividade encarnada por onde a percepção poética encontra sua via mais eficaz de inauguração.

Esse sistema de relações opositivas - em que interessa pensar não as oposições, mas os modos relacionais - incide justamente no mote encaminhador da minha proposta de leitura: o nome-corpo, a maneira como a subjetividade se elabora mediante a recorrência do corpo como metáfora da existência. É como se o sujeito da escrita nos fizesse ver (e o verbo é mesmo esse, uma vez que a elaboração do poema "o meu nome é um corpo quente" é toda ela imagética) a vida que decorre dessa escrita, a vida própria que só pode ser anunciada por meio desse jogo móbil que escapa a qualquer fixação conceitual. O poema seria, então, a captura do instante perceptivo, o corpo vivo (a vida, movimento), e só pode ser manejado mediante a constatação de que irá incessantemente mudar de sentido. Tal é a captura: o poema como um movimento que se refaz de dentro para fora, de fora para dentro - do corpo. 


\subsection{Nomes e corpos, escritas de que percepção?}

Para finalizar essas reflexões, considero que um apanhado de alguns dos pontos evidenciados pelas leituras precedentes seria uma boa maneira de perceber algumas similaridades e algumas diferenças entre os três poetas no que se refere ao recorte temático. Dos poemas selecionados a partir da coincidência da relação intrínseca entre o nome e o corpo, importa retomar alguns aspectos dessa relação e verificar em que termos ela se dá em cada um dos poetas.

Em Herberto Helder tudo que temos é um pronome, “eu”; em Cesariny, a enunciação do nome próprio e a sua subsequente recusa; e em Cruzeiro Seixas o nomecorpo, de tal modo que o nome passa a ser um corpo-outro em relação ao sujeito da enunciação. Em todos, a corporeidade do nome se faz ver enfaticamente, entretanto, parece haver uma gradação que demarca uma maior importância à metalinguagem (no caso de Herberto Helder), passando pela necessidade de uma "reescrita", por assim dizer, ou de uma reelaboração dos modos de estabelecimento de vínculo entre os nomes e os corpos (no caso de Cesariny), em que poderíamos supor uma metalinguagem pelas vias da subversão e, por fim, o eixo máximo dessa relação entre nome e corpo: o nome como um corpo, dotado de materialidade e autonomia (no caso de Cruzeiro Seixas).

Os percursos para a formalização poética dessa percepção do sujeito da escrita ou do próprio nome - e dizemos "próprio nome", uma vez que, embora apenas Cesariny enuncie o nome próprio, tanto HH quando Cruzeiro Seixas fazem uso do pronome possessivo: "o meu nome" - são, em muitos momentos, convergentes: basta atentar para algumas imagens similares como a "luz" em Herberto Helder ("A luz apoia-se nos planos de ar e água sobrepostos"); a brancura do "poema" em Cesariny ("Disse que és alto/ alto/ branco e despovoado"290); a "brancura" e a "luz" em Cruzeiro Seixas ("tudo se cobre da brancura excessiva da luz"). Imagens que não esgotam, no entanto, as vias de acesso ao poema, já que também nos três poetas são recorrentes imagens que implicam o contrário da luz, como o "escuro" (coroado pela boca, este "poro monstruoso") e o "Tubo" em Herberto Helder; a "caverna" e o "túnel” em

\footnotetext{
${ }^{290}$ Retomamos o segundo poema analisado, pois também nele a busca pelo "próprio" ocorre em metalinguagem similar à que ocorre em "a antonin artaud", como atestam os versos: "A minha boca/ sabe à tua boca", de modo que o sujeito da escrita (embora o nome próprio não seja evocado) está, também aqui, implicado pela elaboração poética. Essa mútua implicação entre subjetividade e escrita vale também para o outro poema de Herberto Helder evocado neste parágrafo.
} 
Cesariny; a "noite" ("outras noites antigas") em Cruzeiro Seixas.

Ora, esse claro-escuro parece ser a ambiência eleita por todos quando se trata de pensar a subjetividade em termos de elaboração poética. Daí que a ambiguidade presente na ideia de phármakon nos pareceu um modo bastante eficaz para pensar, com Merleau-Ponty, essa predominância da percepção enquanto eixo que se situa para além das formas fixas e geometricamente mensuráveis, para além do pensamento binário e opositivo, permitindo uma composição que atente para essa espécie de "movência" implicada nas múltiplas combinações perceptivas que os sentidos podem ofertar à criação artística. Esse princípio de mobilidade é exposto com bastante clareza na seguinte reflexão de Merleau-Ponty a respeito de Cézanne:

[Ele] não quer separar as coisas fixas que nos aparecem ao olhar de sua maneira fugaz de nos aparecer, quer pintar a matéria ao tomar forma, a ordem nascendo por uma organização espontânea. Para ele a linha divisória não está entre 'os sentidos' e a 'inteligência', mas entre a ordem espontânea das coisas percebidas e a ordem humana das idéias e das ciências. ${ }^{291}$

Atentos a ambiguidade fundadora do percurso poético estiveram todos: Herberto Helder, para quem a pronúncia do nome mediante a escrita implica a dor, a ferida; bem como o êxtase, a iluminação; Mário Cesariny, que reivindica a "Coragem" (assim grafada com inicial em caixa alta, a se destacar de outros vocábulos) e elege Artaud - aquele que opta por enfrentar a crueldade - como companheiro de busca do nome próprio; e Cruzeiro Seixas que reconhece a guerra e o crime como parte deste que é o mesmo empenho em direção ao nome próprio: a poesia e os modos subversivos que ela encontra de violar o nome de batismo - a convenção, a percepção fixada -, como lemos em Cesariny.

Ainda uma última observação sobre a delimitação do sujeito que acaba por servir como disparadora para o capítulo subsequente (em que trataremos da relação intersubjetiva): nos três casos parece haver um justo equilíbrio entre as limitações impostas pelo corpo (se pensado objetivamente, como uma massa que ocupa um espaço) e a situação deste mesmo corpo, no sentido do ser que se revela em situação, conforme as diretrizes fenomenológicas. Por tratar-se de corpos percebidos, ao mesmo tempo que condicionados pelos respectivos discursos poéticos (em que a criação

\footnotetext{
${ }^{291}$ MERLEAU-PONTY, Maurice. "A dúvida de Cézanne" In: Coleção "Os Pensadores". São Paulo: Abril Cultural, 1980, p. 116.
} 
mediante a reelaboração da linguagem, portanto, está implicada), a situação varia de caso para caso, isto é, o campo de atuação poética eleito por cada um dos três revela a situação que vai condicionar as relações destes corpos com o mundo (bem como o recorte de mundo que será eleito). Como vimos no primeiro capítulo, a demarcação de atuação poética de Herberto Helder é muito pautada pela individualidade, enquanto no caso de Cesariny e de Cruzeiro Seixas, fiéis ao postulado surrealista da atuação coletiva (que , embora não tenha ocorrido como prática constante, sempre foi meta e bandeira hasteada dos surrealistas) a marca da individualidade é atravessada por outras vozes que contribuem na composição desses sujeitos surrealistas. Ora, a situação poética em que estes corpos e nomes se enunciam, em cada caso, confirma, em certos termos, essa demarcação de atuação poética a qual nos referimos. Em Herberto Helder, o indivíduo "eu”, é mesmo indivisível, se pensado em relação a outros indivíduos, isto é, não há nenhum "outro" que seja convocado à cena, embora seja possível sugerir que a "repartição" a que este "eu" está sujeito ao longo dos tempos ("No retrato, no rosto, nas idades em que,/gramatical, carnalmente, me reparto.”), implique numa multiplicidade de "eus" que, entretanto, não deixam de ser subsumidos pelo "eu" que baliza o poema. Em Cesariny, a recusa do nome próprio e a convocação de Artaud no poema apontam, simultaneamente, para essa flutuação do indivíduo, que parece encontrar abrigo em nomes e corpos outros, tendendo para essa espécie de "eu coletivo" cuja demarcação é uma linha tênue e permeável. Em Cruzeiro Seixas, nos deparamos com um espécie de meio termo entre a postura de Herberto Helder e a postura de Cesariny, uma vez que, embora signatário do coletivismo surrealista (como vimos, por exemplo, mediante a apropriação das palavras de Lautréamont: "La poésie doit être faite par tous, non par un.”), é apenas por meio da própria individualidade que o nome aparece. Uma individualidade, como vimos, nem tão indivisível assim, muito pelo contrário: "eu" e "nome" são duas pessoas distintas no discurso poético, o "nome" é outro corpo, autônomo mesmo. Essa oscilação entre "eu" e "outro", de que se reveste o nome-corpo ali exposto, é que nos permite modalizar a postura de Cruzeiro Seixas em relação à de seu companheiro Cesariny, mas também em relação à Herberto Helder, uma vez que o "outro", em Cruzeiro Seixas, embora não seja evocado mediante outro nome (caso de Cesariny ao evocar Artaud), é evocado mediante o próprio nome ("o meu nome"), indício suficiente para se considerar essa subjetividade como flutuante, uma vez que, como em Cesariny, o limite de demarcação deste "eu" é também uma linha tênue. Novamente Lautréamont aparece mediante comentário pertinente de 
Eliane Robert Moraes, e que muito elucida nosso percurso interpretativo: "[Isidore Ducasse] representava um ataque frontal ao princípio de identidade: nos seus Cantos é impossível discernir o autor do personagem, sendo que cada qual remete a uma sucessão de desdobramentos. ${ }^{, 292}$, por esse motivo - e ainda segundo a pesquisadora "Os surrealistas dedicaram um verdadeiro culto a Idore Ducasse." 293.

Essas reflexões, entretanto, serão mais pormenorizadamente desenvolvidas no próximo capítulo, mediante a leitura de poemas que trazem a questão das relações entre "eu" e "outro".

\footnotetext{
${ }^{292}$ MORAES, Eliane Robert. O corpo impossível. São Paulo: Iluminuras, 2002, p. 40.

${ }^{293}$ Idem, Ibidem.
} 


\section{Capítulo III:}

A Relação intercorpos 


\subsection{O amor: argumento em favor da subversão}

Feito o percurso teórico e analítico que tornou possível pensar o sujeito poético a partir de algumas diretrizes fenomenológicas - com ênfase nos aspectos imbrincados corpo/subjetividade/escrita (ou, nos termos em que propus, nos equivalentes vida e obra) - trata-se, neste último capítulo, de pensar a relação intersubjetiva tal como flagrada em cada um dos poetas. Trata-se, portanto, ainda em consonância com as reflexões empenhadas por Merleay-Ponty ${ }^{294}$, de uma continuidade ou expansão, isto é, pensar as relações intersubjetivas nos poemas significa também pensar o sujeito poético, desde que os termos dessa subjetividade estejam inevitavelmente marcados pela relação, ou melhor: a subjetividade se constitui na relação, depende dela para que se estabeleça.

Adiante, importará perceber que a relação intersubjetiva deve ser considerada de acordo com a flexibilização de limites de estabelecimento identitário, conforme esboçado nos capítulos anteriores.

Tendo em vista que a relação intersubjetiva poderia ser focalizada de uma imensa diversidade de perspectivas (o "eu" e o "outro" abordados do ponto de vista dos gêneros, do ponto de vista ontológico, social, nacional, racial, histórico...); num primeiro momento, me pareceu adequado eleger apenas uma das perspectivas listadas como delimitação de olhar para a produção criativa em questão. No entanto, não creio que tal abordagem "vertical" e demasiado específica seria muito generosa - ou até mesmo coerente - considerando-se a diversidade de aspectos mobilizados pelo modo como a intersubjetividade ocorre em Herberto Helder, Cesariny e Cruzeiro Seixas. Desse modo, me pareceu boa solução eleger o amor como ponto de contato entre as diversas formas de relação possíveis, considerando a maior frequência com que as questões raciais/nacionais e de gênero aparecerão na obra de cada um dos autores.

A eleição do amor como elo interacional entre as diversas formas de relação intersubjetiva, isto é, selecionar o ideário do "amor" como forma relacional que precede e condiciona todas as outras relações intersubjetivas, me parece uma escolha adequada: trata-se de partir do amor, espécie de termo abrangente, para pensar as demais formas de relação. Tal eleição se justifica por ser o amor um dos pilares

\footnotetext{
${ }^{294}$ No que interessa para o propósito da presente pesquisa, exatamente como foram expostas no primeiro capítulo (retomadas, pontualmente, no segundo capítulo). Uma vez que se supõem pano de fundo de toda a discussão que abarca a pesquisa, as reflexões não serão novamente mencionadas.
} 
fundadores da proposta surrealista e certamente aquele que possibilitou a coerência criativa $^{295}$ dos surrealistas mediante o elo com os dois outros pilares: a liberdade e a poesia. É de se considerar ainda, o fato de que o primeiro livro publicado por Herberto Helder, em 1958, é um longo poema intitulado $O$ amor em vista, de modo que é inquestionável afirmar a assunção da "perspectiva amorosa", por assim dizer, por parte dos três poetas em questão.

Tendo o amor como elo primeiro para se pensar a intersubjetividade - elo que confirma a aproximação, na qual venho insistindo, entre Cruzeiro Seixas, Herberto Helder e Cesariny - importa buscar algumas reflexões que situam o amor no contexto de ideias e escolhas éticas de que participam os três autores em questão. Tanto mais evidente, pois também o amor - ao lado da percepção sensorial, conforme foi possível perceber mediante a fenomenologia de Merleau-Ponty - acaba servindo à subversão suposta nas manifestações poéticas das linhagens dos três autores aqui eleitos, uma vez que o amor desafia a unilateralidade da razão no que diz respeito ao comportamento dos homens em sociedade e aos valores morais predominantes. Do ponto de vista da razão, poderíamos mesmo dizer que o amor se avizinha da loucura, esta condição existencial tão elogiada pelos poetas em questão ${ }^{296}$. Sobre isso, importante ressaltar o título de um dos grandes livros de André Breton: L'Amour fou (O Amor louco), em que a loucura, servindo assim de adjetivo ao amor, expressa não apenas a intensidade que qualifica o amor (em oposição à justa medida da razão), mas especialmente o rompimento com a ideia de causalidade que preside a toda lógica ocidental: contra as relações de causa e efeito como forma privilegiada de leitura de mundo, a loucura dos surrealistas vai privilegiar o acaso objetivo, conforme discorre Octavio Paz:

Há mil variantes do encontro, mas em todas elas intervém um agente que às vezes chamamos sorte, outras casualidade e outras destino ou predestinação. Casualidade ou destino, essa série de fatos objetivos regidos por uma causalidade externa, cruza-se com nossa subjetividade, nela se insere e transforma-se numa dimensão do mais íntimo e poderoso em cada um de nós - o desejo. Breton lembrou

\footnotetext{
${ }^{295}$ O que aqui nomeio como coerência não incide sobre o estilo do resultado criativo (literário/plástico), mas sim incide sobre o ato da criação artística mesma, e o modifica em função do seu propósito: mudar as bases civilizacionais do ocidente, nunca é demais repetir, orientadas pela perspectiva logocêntrica.

${ }^{296}$ Apenas para mencionar pontualmente algumas ocorrências: conforme verso do poema em homenagem à Artaud lido no capítulo anterior, Cesariny não hesita em afirmar a loucura como propriedade dos sábios ("nem a loucura dos Sábios (...)"), e Herberto Helder, que vai conotar a loucura de forma bastante entusiasmada, também em alta valoração: "e eu que sou louco, um pouco, não ao ponto de ser belo ou maravilhoso ou assintáctico ou mágico, mas:/ um pouco louco, porque faço com mãos estilísticas um inverno fora e dentro dos estados naturais:" (HELDER, Herberto. Ofício cantante. Lisboa: Assírio \& Alvim, 2009, p. 583.)
} 
Engels e denominou a interseção das duas séries, a exterior e a interior, de acaso objetivo (...). A série causal exterior se cruza com uma causa interna: o inconsciente. Ambas são alheias à nossa vontade, ambas nos determinam e sua conjunção cria uma ordem, um tecido de relações, sobre o qual ignoramos tanto a finalidade como a razão de ser. ${ }^{297}$

Esse avizinhamento entre amor e loucura que aqui suponho na esteira dos surrealistas, também se justifica pela imposição do indivíduo como vontade a despeito de qualquer coerção social (o que em alguma medida caracteriza também a loucura), mais ou menos como explicita Barthes nesse trecho de Fragmentos de um discurso amoroso:

\begin{abstract}
AFIRMAÇÃO. Contra tudo e todos, o sujeito afirma o amor como valor.

1. Apesar das dificuldades da minha história, apesar dos mal-estares, das dúvidas, dos desesperos, apesar dos ímpetos de abandonar tudo, não paro de afirmar em mim mesmo o amor como um valor. Todos os argumentos que os mais diversos sistemas empregam para desmistificar, limitar, esmaecer, em suma, depreciar o amor, escutoos, mas obstino-me: "Sei disso, mas mesmo assim..." Atribuo as desvalorizações do amor a uma espécie de moral obscurantista, a um realismo-farsa, contra os quais ergo o real do valor: oponho a tudo "o que não vale a pena" no amor a afirmação do que nele vale. Esta teimosia é a profissão do amor: sob o concerto das "boas razões" de amar de modo diferente, de amar melhor, de amar sem estar enamorado, etc., uma voz teimosa se faz ouvir que dura um pouco mais de tempo: voz do Intratável amoroso. ${ }^{298}$
\end{abstract}

Essa citação, no entanto, se ocupa do amor no âmbito individual: a pretexto de se apresentar na sua condição de sujeito amoroso (o livro todo é redigido em primeira pessoa, a simular uma confissão), o que Barthes propõe de fato é uma análise do discurso amoroso, e nesse trecho, particularmente, evidencia-se o carácter transgressivo do amor (como a abordagem é direcionada ao indivíduo e trata de apresentar a psicologia do apaixonado mediante a sua construção discursiva, o termo usado, que aqui considero próximo à "transgressão", é “teimosia"). Nessa mesma perspectiva, entretanto, mediante abordagem que se propõe pensar o amor do ponto de vista social, falam Michel Leiris e Octavio Paz, com a vantagem de compartilharem ambos do ideário surrealista - guardadas as devidas diferenças, matizes e oscilações ao longo das respectivas produções -, de modo que, no caso das reflexões sobre o amor

\footnotetext{
${ }^{297}$ PAZ, Octavio. A dupla chama: amor e erotismo. São Paulo: Siciliano, 1994, p.131.

${ }^{298}$ BARTHES, Roland. Fragmentos de um discurso amoroso. São Paulo: Martins Fontes, 2003, pp. 15, 16.
} 
apresentadas por Leiris e Paz, a adequação em relação aos poetas estudados é ainda mais pertinente.

Segundo Michel Leiris em sua curiosa aproximação entre a arte tauromáquica e o amor, plenamente de acordo com a tomada de partido dos surrealistas em favor do amor como a forma primordial da manifestação de fatos reveladores, há uma dupla provocação que se dirige à "hipertrofia do pensamento lógico" e à "rendição a um empirismo estreito":

Reagentes de uma espécie de química moral, cujas reações coloridas trariam à luz alguns dos turbilhões confusos que se agitam em nossos recessos, esses fatos reveladores tornam-se cada vez menos frequentes numa época como a nossa, esmagada pela necessidade imediata e engrenada de tal modo que o homem parece a cada instante mais resignado a esse divórcio de si mesmo que se dá pela hipertrofia do pensamento lógico ou, pior ainda, pela rendição a um empirismo estreito, camuflado mais ou menos habilmente sob a etiqueta de 'realismo'. ${ }^{299}$

Ora, curioso é notar que o amor (desde sempre visto como forma de relação) é apresentado como termo que protegeria o sujeito do "divórcio de si mesmo": expressão que, conforme aparece encadeada no trecho supracitado, muito diz das alienações $^{300}$ a que o pensamento lógico, juntamente com a crença (não creio ser exagero afirmar uma fé cega) gerada pelo hábito do "empirismo estreito", operariam nas subjetividades. Curioso justamente porque o amor é o termo que reconduziria os sujeitos à autenticidade pretendida - e, portanto, à libertação de uma série de grilhões sociais, daí a subversão implicada - e sendo o amor um termo interacional, essa autenticidade, deduzo, seria resultado de uma operação intersubjetiva, isto é, dependeria da relação, do contato com outras subjetividades. Se dermos um passo além, é possível concluir: para que o sujeito esteja pleno de si, há que se ter contato com o outro. André Breton expressa essa autenticidade possibilitada pelo amor relacional da seguinte maneira, em Amor louco: “(...) tudo se passa, realmente, como se eu me tivesse perdido e alguém, de repente, me viesse dar notícias minhas." ${ }^{\text {’01 }}$.

Rebelar-se contra o pensamento lógico e contra o realismo estreito não é

\footnotetext{
${ }^{299}$ LEIRIS, Michel. Espelho da tauromaquia. São Paulo: Cosac \& Naify, 2001, pp. 13, 14.

${ }^{300}$ Importa frisar que escolho o vocábulo alienações propositadamente: sempre que usado para se referir ao louco ("alienado"), o termo marca, ao mesmo tempo que camufla, a tomada de posição do racionalismo, sendo por mim usado como forma de provocação e em confluência com a subversão operada pelos autores aqui requisitados.

${ }^{301}$ BRETON, André. Amor louco. Lisboa: Editorial Estampa, 1971, p. 12.
} 
novidade para a linhagem surrealista (nem para Herberto Helder), tampouco poderia se dizer nova a concepção de que o amor teria grande força nessa rebelião, mais ou menos como sugere a palavra "teimosia" aplicada por Barthes para caracterizar o sujeito enamorado. Trata-se, pois, da transgressão enfaticamente evidenciada nos seguintes dizeres de Leiris:

Nenhum prazer estético será então possível sem que haja violação, transgressão, excesso, pecado em relação a uma ordem ideal que faz as vezes da regra; não obstante, uma licença absoluta, como uma ordem absoluta, não teria como ser mais que uma abstração insípida e desprovida de sentido. Assim como a morte subjacente dá cor à vida, assim o pecado, a dissonância (que contém em germe, que sugere uma destruição possível) confere beleza à regra, arranca-a de seu estado de norma enrijecida para fazer dela um polo ativo e magnético - do qual nos destacamos ou para o qual tendemos. ${ }^{302}$

Novamente a estética em cena: não com a significação pejorativa divulgada entre os surrealistas (isto é, como adorno ou qualidade superficial desprovida de interesse vital e ético), mas propriamente como a etimologia indica (e como eu propus em outro momento), isto é, como vínculo sensorial com o mundo. Nesse caso, colocase em relevo, a um só tempo, a criação artística e o erotismo:

De fato, o erotismo pode ser definido strictu sensu como uma 'arte do amor', uma espécie de estetização do mero amor carnal, doravante organizado como uma sequência de experiências cruciais. Contudo, lato sensu, ele se confunde com o conjunto das 'obras da carne', no sentido cristão do termo; e pode-se mesmo indagar se alguma excitação sexual seria jamais possível sem a intervenção de um mínimo de erotismo, seja sob a forma da ideia de pecado (concebido de maneira romântica ou sob o aspecto inverso da licenciosidade), seja sob a forma de uma noção de jogo, de luxo, de prazer usufruído sem qualquer consideração de utilidade, ou seja, sob a forma de uma ideia particularmente estética. ${ }^{303}$

Ora, também Octavio Paz compartilha dessa visada sobre o amor; tanto no que diz respeito ao seu poder transgressor, quanto no que diz respeito ao erotismo como vínculo estético-intersubjetivo: o vínculo que se estabelece com o "outro". A começar por essa associação entre erotismo e estética, importa sobretudo dizer que é um vínculo de maior relevância para se pensar o vínculo entre amor e escrita poética. Não apenas porque ambos - erotismo e poesia - se debruçam sobre as refigurações da convenção

\footnotetext{
${ }^{302}$ LEIRIS, Michel. Espelho da tauromaquia. São Paulo: Cosac \& Naify, 2001, p. 39.

${ }^{303}$ Idem, pp. 41, 42.
} 
(ressignificar o ato sexual, no primeiro caso, e ressignificar as formas de elaboração da subjetividade e seus modos de comunicação, no segundo caso), mas também porque ambos implicam a retomada da autenticidade subjetiva, mediante o contato com o outro, isto é, o termo relação, merece maior deferência quando se trata de supor erotismo e poesia. Sobre isso, assim se pronuncia Octavio Paz:

\begin{abstract}
A relação entre erotismo e poesia é tal que se pode dizer, sem afetação, que o primeiro é uma poética corporal e a segunda uma erótica verbal. Ambos são feitos de uma oposição complementar. A linguagem - som que emite sentido, traço material que denota ideias corpóreas - é capaz de dar nome ao mais fugaz e evanescente: a sensação; por sua vez, o erotismo não é mera sexualidade animal - é cerimônia, representação. $O$ erotismo é sexualidade transfigurada: metáfora. A imaginação é o agente que move o ato erótico e o poético. É a potência que transfigura o sexo em cerimônia e rito e a linguagem em ritmo e metáfora. ${ }^{304}$
\end{abstract}

Neste trecho, é relevante destacar a importância que o corpo adquire na comparação entre erotismo e poesia: em pleno acordo com a base filosófica proposta por Merleau-Ponty, o aspecto sensorial da comparação é enfatizado no sentido de operar em favor da subversão: "Nossa tradição, desde Platão, exalta a alma e menospreza o corpo. Diante dela e desde suas origens, o amor enobreceu o corpo: sem atração física, carnal, não há amor." ${ }^{305}$. Nesse mesmo sentido, Octavio Paz, ao tratar da continuidade histórica do amor (tendo como pressuposto que o amor cortês seria a origem do amor - na concepção ocidental atual -), se pronuncia:

Ao falar da continuidade do amor é útil repetir que não me refiro ao sentimento, que provavelmente permanece em todos os tempos e lugares, mas às concepções sobre essa paixão elaboradas por algumas sociedades. Essas concepções não são construções lógicas: são a expressão de profundas aspirações psíquicas e sexuais. Sua coerência não é racional, mas vital. Por isso eu as denomino imagens. Acrescento que, se não são uma filosofia, são uma visão de mundo e, assim, são também uma ética e uma estética: uma cortesia. . $^{306}$

Sobre o poder transgressor e subversivo do amor (incluindo o sexo como uma das formas de sua manifestação), Octavio Paz é insistente: "O sexo é subversivo: ignora as classes e hierarquias, as artes e as ciências, o dia e a noite; dorme e só acorda

\footnotetext{
${ }^{304}$ PAZ, Octavio. A dupla chama: amor e erotismo. São Paulo: Siciliano, 1994, p. 12.

${ }^{305}$ Idem , p. 115.

${ }^{306}$ Idem, p. 122.
} 
para fornicar e voltar a dormir."307, e ainda: "O amor se apresenta, quase sempre, como uma ruptura ou violação da ordem social; é um desafio aos costumes e às instituições da comunidade. É uma paixão que, ao unir os amantes, os separa da sociedade.”308, e, especialmente sobre o aspecto relacional e modificador da subjetividade nele implicado:

O amor tem sido e é a grande subversão do Ocidente. Como no erotismo, o agente da transformação é a imaginação. Mas, no caso do amor, a mudança se dá em relação contrária: não nega o outro nem o reduz a sombra, mas é negação da própria soberania. Essa autonegação tem uma contrapartida: a aceitação do outro. ${ }^{309}$

Ainda supondo a relação intersubjetiva implicada nessa forma interacional que é o amor, lemos: "No amor tudo é dois e tudo tende a ser um."310. Sobre esta aparente fusão do "eu" e do "outro", as reflexões se estenderão a seguir, no momento de leitura dos poemas. Importa referir também o seguinte pronunciamento de Breton:

Sinto-me tentado a afirmar que os dois indivíduos que assim caminham a par um do outro constituem uma máquina única de dupla influência. $\mathrm{O}$ achado, a meu ver, vem de súbito equilibrar dois níveis distintos de reflexão, à semelhança dessas bruscas condensações atmosféricas que tem por efeito tornar condutoras regiões que antes não o eram, e assim provocar relâmpagos. ${ }^{311}$

A ênfase no amor erótico, tal como observamos nas diversas citações acima, permite que o aspecto carnal seja evidenciado e, portanto, há coerência com a ênfase na sensorialidade dada pela fenomenologia, tal como desenvolvida por Merleau-Ponty (coerência que nos permitiu pensar conjuntamente o corpo-existência e a criaçãopoesia). O que proponho, no entanto, é que a intensidade suposta no amor erótico seja um princípio possível de se identificar na relação intersubjetiva mesmo quando esta esteja desprovida de interesse sexual, como seria o caso, por exemplo, das relações nacionais ou raciais. Espero com isso esclarecer a proposta, apresentada no começo

\footnotetext{
${ }^{307}$ PAZ, Octavio. A dupla chama: amor e erotismo. São Paulo: Siciliano, 1994, p. 17.

${ }^{308}$ Idem, p. 103

${ }^{309}$ Idem, p. 112.

${ }^{310}$ Idem, p. 118.

${ }^{311}$ BRETON, André. Amor Louco. Lisboa: Editorial Estampa, 1971, pp. 42, 43.
} 
deste capítulo, de eleger o amor como princípio interacional prévio que direcionaria as demais formas de relação (imagino que, em alguma medida, essa era a ambição dos surrealistas e de Herberto Helder, como tentarei demonstrar na leitura dos poemas). Desse modo, o amor passa a ser componente primordial da subjetividade, e no caso dos poetas em questão, elevado a um maior grau de importância do que a razão e a consequente padronização comportamental (cerceamento de acordo com o padrão) que ela promove. O próprio Hegel já estava atento a este fato: "O amor exclui todas as oposições e por isso escapa ao domínio da razão... Anula a objetividade e assim vai além da reflexão... No amor a vida descobre a si própria já isenta de qualquer incompletude" ${ }^{312}$. Sobre a anulação da objetividade aqui mencionada, vale a pena considerar a afirmação de Breton: “(...) eu espero desferir mais um golpe nessa, a meu ver, cada vez mais infundada distinção criada entre o subjetivo e o objetivo."313; ora, Hegel e Breton expressam uma mesma perspectiva (bem de acordo com a fenomenologia): a objetividade só é anulada na medida em que se torna impossível distinguir entre o "dentro" e o "fora", por assim dizer; exatamente - insisto - como a teoria proposta por Merleau-Ponty. Por isso, como já observado na leitura dos poemas no capítulo anterior, a transparência é um valor - já que simboliza o trânsito entre o dentro/subjetivo e o fora/objetivo - e a opacidade, por consequência, como afirma André Breton em Arcano 17, é um contra valor: "A grande inimiga do homem é a opacidade. Essa opacidade está fora dele e ela está sobretudo nele, onde as opiniões convencionais e todos os tipos de proibições suspeitas mantêm-na viva." ${ }^{314}$, e, em Nadja (neste, que é um dos livros mais revolucionários sobre o amor), a afirmação da transparência:

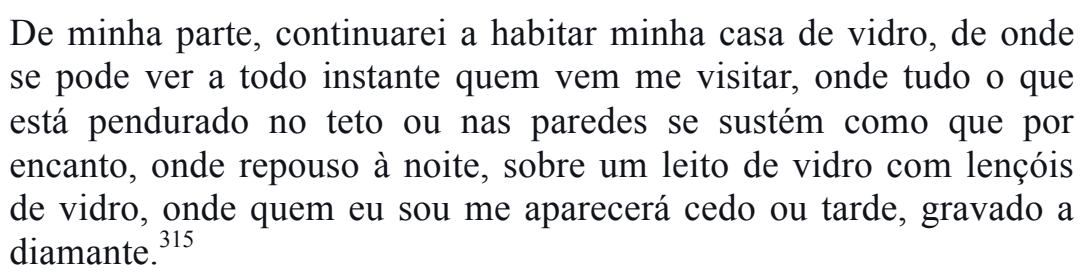

Daí a subversão que o amor seria capaz de promover; subversão esta que

\footnotetext{
${ }^{312}$ HEGEL Apud PAZ, Octavio. A dupla chama: amor e erotismo. São Paulo: Siciliano, 1994, p. 129.

${ }^{313}$ BRETON, André. Amor Louco. Lisboa: Editorial Estampa, 1971, pp. 71, 72.

${ }^{314}$ BRETON, André. Arcano 17. São Paulo: Editora Brasiliense, 1986, p. 29.

${ }^{315}$ BRETON, André. Nadja. São Paulo: Cosac Naify, 2007, p. 26.
} 
ultrapassa em muito o amor erótico (embora o inclua), para abarcar uma forma de relação em que se subvertem os limites subjetivos/objetivos (novamente Breton: "Pode-se sistematicamente, sem incorrer em qualquer delírio, trabalhar para que a distinção entre o objetivo e subjetivo perca a sua necessidade e o seu valor., ${ }^{\text {’16 }}$ ), ao mesmo tempo em que pressuponha o amor - em detrimento da razão - na mais alta valoração ética/estética.

Georges Bataille vai formular essa transgressão em direção semelhante:

O erotismo, eu o disse, é aos meus olhos o desequilíbrio em que o próprio ser se põe conscientemente em questão. Em certo sentido, o ser se perde objetivamente, mas nesse momento o indivíduo identifica-se com o objeto que se perde. Se for preciso, posso dizer que, no erotismo, EU me perco. Não é, sem dúvida, uma situação privilegiada. Mas a perda voluntária implicada no erotismo é flagrante. Ninguém pode duvidar disso. Falando agora do erotismo, tenho a intenção de me exprimir sem rodeios em nome do seu sujeito, mesmo se, para começar, introduzo considerações objetivas. Mas se eu falo dos movimentos do erotismo objetivamente, devo dizer logo de saída, é que nunca a experiência interior é dada independentemente de visões objetivas. Nós a encontramos sempre associada a determinado aspecto, inegavelmente objetivo. ${ }^{317}$

Para encerrar essa primeira reflexão sobre o tema - que prepara a discussão que será retomada na leitura dos poemas - é importante concluir, ressaltando o amor, tal como visto por essa linhagem de pensadores e poetas, como a maior das forças revolucionárias (numa revolução em que seria a própria “cabeça"/razão mesma da civilização, a grande vítima da guilhotina), sendo o seu poder de ação social muito bem expresso mediante as seguintes palavras de André Breton: "Sempre que um homem ama, nada o pode impedir de empenhar, juntamente com a sua, a sensibilidade de todos os outros homens. Para não desmerecer deles, é sua obrigação empenhá-la a sério.”318.

\footnotetext{
${ }^{316}$ BRETON, André. Arcano 17. São Paulo: Editora Brasiliense, 1986, p. 105.

${ }^{317}$ BATAILLE, Georges. O erotismo. São Paulo: L\&PM, 1987, p. 29.

${ }^{318}$ BRETON, André. Amor Louco. Lisboa: Editorial Estampa, 1971, p. 104.
} 


\subsection{Herberto Helder e a gênese (gestação) do amor}

Em ensaio intitulado "Maternidade e truculência", Gustavo Rubim traça um panorama da maneira pela qual Herberto Helder se dedica em "inventar a sua própria tradição, contra os esquemas rígidos da historiografia instituída"319. Para tanto, parte dos seguintes versos de Fonte: "As mães são as mais altas coisas/ que os filhos criam $^{, 320}$, de modo que a maternidade inscrita no título do ensaio, serve de metáfora para a subversão implicada na suposta filiação paterna dos autores herdeiros da modernidade poética (note-se, como quer o ensaísta, que a paternidade é, portanto, a metáfora representativa de uma tradição literária canônica):

Talvez aquilo em que Herberto Helder seja mais moderno coincida precisamente com o seu trabalho de desintegração da suposta unidade da poesia moderna, um trabalho que não pode deixar de correr essas unidades mais pequenas (e igualmente supostas) a que chamamos "modernismo", "romantismo" ou, por exemplo, "surrealismo". São nomes que usamos à procura de uma paternidade garantida (...), ademais, a paternidade será, como vimos, uma questão poeticamente menor; o essencial de qualquer filiação joga-se na maternidade, na criação das mães pelos filhos (...). ${ }^{321}$

É um verdadeiro golpe de mestre a associação proposta por Gustavo Rubim entre a subversão à tradição canônica e a recorrência com que a figura materna aparece na obra de Herberto Helder. Sobre esta última, pouco nos fala o ensaísta, embora o leitor minimamente atento não pode deixar de notar que a "mulher-mãe" permeia e justifica todo o ensaio, do mesmo modo como atravessa e caracteriza grande parte da obra herbertiana. Não é a primeira vez, aliás, que a crítica se debruça sobre essa recorrência; já em 1979, Maria Estela Guedes, impulsionada pela leitura de "Teorema" (Os passos em volta), afirma: "Na obra herbertiana não há pátrias nem países, há somente mátrias e maíses, a carta poética pela qual se vai dando a vida, à qual se vai dando o corpo. Estranho mas pungente, o assumir-se como mãe nota-se em muitos textos $\left(\ldots . .{ }^{322}{ }^{3}\right.$. Também Jorge Fernandes da Silveira vai se encarregar de explicitar a

\footnotetext{
${ }^{319}$ RUBIM, Gustavo. "Maternidade e truculência" In: A arte de sublinhar. Coimbra: Angelus Novus, 2003, p. 125.

${ }^{320}$ HELDER, Herberto. Fonte. Lisboa: Assírio \& Alvim, 1998, p. 10.

${ }^{321}$ Idem, pp. 126, 127.

${ }^{322}$ GUEDES, Maria Estela. Herberto Helder, poeta obscuro. Lisboa: Moraes Editores, 1979, p. 185.
} 
força subversiva contida na imagem materna tal como aparece em Herberto Helder, não podendo fazê-lo, entretanto, sem colocar em cena o próprio Camões. Assim Jorge Fernandes começa o seu ensaio:

Falo de António José Saraiva. Falo mais propriamente do que me calou alto nos ouvidos, chegando até a despertar uma vontade de pesquisa futura que, agora, como hipótese de ensaio em expansão, aqui apresento. Dizia ele: O matricídio na cultura portuguesa. Pensem nisso. Sim, a história, o mito, a lenda do filho que mata a mãe, Afonso Henriques e Tareja. A origem de todos os nós de nós todos, e também Fernando e Leonor Teles, e, porque sim, Pedro e Inês. Tudo isso merece um estudo, um pesquisa rigorosa. Pensem nisso. $^{323}$

Adiante, reproduzo longa citação em que Jorge Fernandes se ocupa em demonstrar, passando por Camões, de que modo a tradição lírica portuguesa ${ }^{324}$ propaga a ideia (subvertida por Herberto Helder) da mulher pecadora, sempre que sensualmente manifesta:

O Amor em visita (1958) é título de poema-livro de Herberto Helder, sem dúvida "o habitante de um nome" (Última ciência, 1988) tutelar na lírica portuguesa do século XX. Se insisto na forma de estar no poema, na casa, como metáfora estruturante da inter-relação amorosa autor/nação (Silveira, 1999), é porque na comunidade de poetas que estudo habitam extraordinários amantes filhos da mãe, i.e., da pátria. Como o autor de $A$ colher na boca que, "no sorriso louco das mães" ("Fonte", A colher na boca, 1961), põe à prova amores de berço em que o instinto e o desejo se fundem na mais feroz ciência da sexualidade humana; porque "nela", parodiando a imagem camoniana de D. Tareja, mãe de Afonso Henriques, primeiro rei de Portugal, "onde se escreve mãe e filho" (Última ciência, 1988), "o sensual era maior" (Lus., III, 31, 8).

Trocando os versos em miúdos. Nas estrofes 31 e 32 do canto III d'Os Lusíadas, de Luís de Camões, interpreto, como se fosse uma inscrição arcaica, o relacionamento entre o escritor e a pátria gerada na e pela figura da mãe, fonte da metáfora fundacional lingua mater. Uma matriz traumática, contudo, como já nos disseram Saraiva e Lourenço. Resta deixar, como hipótese de desenvolvimento futuro, a indagação de ser ou não esse nascimento como todos os outros, seguindo O labirinto da saudade, um "acto sem história". Tal falta, fosse eu versado na análise lacaniana, poderia ainda ser interpretada a partir do aforismo "o amor é dar o que não se tem"?

De Guimarães o campo se tingia

${ }^{323}$ SILVEIRA, Jorge Fernandes da. "O Amor Cru: Herberto Helder e Camões ou As Duas Mães" In: Verso com verso. Coimbra: Angelus Novus, 2003, p. 73.

${ }^{324}$ Considerando aqui, como o faz o próprio Jorge Fernandes da Silveira, o lirismo inscrito no épico $O s$ Lusíadas. 
Co sangue próprio da intestina guerra,

Onde a mãe, que tão pouco o parecia,

A seu filho negava o amor e a terra.

Co ele posta em campo já se via;

E não vê a soberba o muito que erra

Contra Deus, contra o maternal amor;

Mas nela o sensual era maior.

Ó Progne crua, ó mágica Medeia

Se em vossos próprios filhos vos vingais

Da maldade dos pais, da culpa alheia,

Olhai que inda Teresa peca mais!

Incontinência má, cobiça feia,

São as causas deste erro principais:

Cila, por hua, mata o velho pai;

Esta, por ambas, contra o filho vai."

Sendo, como quer Fernando Pessoa-Bernardo Soares e uma infinidade de repetidores, a "minha pátria a língua portuguesa" (Pessoa, 1982, p. 17), o meu nascimento como sujeito de cultura está marcado pela história do pecado original da mãe em que a sensualidade - desejo e cobiça - é maior do que o amor próprio à sua natureza de ser mãe. É interessante notar que Camões, o censurado questionador dos desconcertos da tirania e das contradições do amor ("Erros meus, má Fortuna, amor ardente"), não perdoa a mãe crua e iníqua: Teresa.

Logo, desde o berço, os sintomas de um imaginário nacional doente e estigmatizado pelo pecado como marca da instância do feminino na cultura - manifestam-se com força já no primeiro livro do génesis da civilização portuguesa, Os Lusíadas. ${ }^{325}$

Sendo notável pela crítica a subversão operada por Herberto Helder, trata-se de, a partir de poema maior - Amor em visita - em que o poeta se dedicou às figurações subversivas do feminino, pensar de que modo a mulher, em $\mathrm{HH}$, se apresenta como o "outro" a partir do qual este "eu" se define. O amor, claro esteja, sendo o eixo maior dessa relação intersubjetiva (conforme abordaremos, o amor erótico), funcionando como catalizador entre os modos de comunicação e, em alguns momentos, de fusão entre alteridade e ipseidade. Segue o poema na íntegra:

Dai-me uma jovem mulher com sua harpa de sombra

e seu arbusto de sangue. Com ela

encantarei a noite.

Dai-me uma folha viva de erva, uma mulher.

${ }^{325}$ Idem, pp. 75, 76. 
Seus ombros beijarei, a pedra pequena

do sorriso de um momento.

Mulher quase incriada, mas com a gravidade

de dois seios, com o peso lúbrico e triste

da boca. Seus ombros beijarei.

Cantar? Longamente cantar.

Uma mulher com quem beber e morrer.

Quando fora se abrir o instinto da noite e uma ave

o atravessar trespassada por um grito marítimo

e o pão for invadido pelas ondas -

seu corpo arderá mansamente sob os meus olhos palpitantes.

Ele - imagem vertiginosa e alta de um certo pensamento

de alegria e de impudor.

Seu corpo arderá para mim

sob um lençol mordido por flores com água.

Em cada mulher existe uma morte silenciosa.

E enquanto o dorso imagina, sob os dedos,

os bordões da melodia,

a morte sobe pelos dedos, navega o sangue,

desfaz-se em embriaguez dentro do coração faminto.

- Oh cabra no vento e na urze, mulher nua sob

as mãos, mulher de ventre escarlate onde o sal põe o espírito,

mulher de pés no branco, transportadora

da morte e da alegria.

Dai-me uma mulher tão nova como a resina

e o cheiro da terra.

Com uma flecha em meu flanco, cantarei.

E enquanto manar de minha carne uma videira de sangue,

cantarei seu sorriso ardendo,

suas mamas de pura substância,

a curva quente dos cabelos. 
Beberei sua boca, para depois cantar a morte e a alegria da morte.

Dai-me um torso dobrado pela música, um ligeiro pescoço de planta, onde uma chama comece a florir o espírito. À tona da sua face se moverão as águas, dentro da sua face estará a pedra da noite.

- Então cantarei a exaltante alegria da morte.

Nem sempre me incendeiam o acordar das ervas e a estrela despenhada de sua órbita viva.

- Porém, tu sempre me incendeias.

Esqueço o arbusto impregnado de silêncio diurno, a noite imagem pungente com seu deus esmagado e ascendido.

- Porém, não te esquecem meus corações de sal e de brandura.

Entontece meu hálito com a sombra, tua boca penetra a minha voz como a espada se perde no arco.

E quando gela a mãe em sua distância amarga, a lua estiola, a paisagem regressa ao ventre, o tempo se desfibra - invento para ti a música, a loucura e o mar.

Toco o peso da tua vida: a carne que fulge, o sorriso, a inspiração.

E eu sei que cercaste os pensamentos com mesa e harpa.

Vou para ti com a beleza oculta, o corpo iluminado pelas luzes longas.

Digo: eu sou a beleza, seu rosto e seu durar. Teus olhos transfiguram-se, tuas mãos descobrem a sombra da minha face. Agarro tua cabeça áspera e luminosa, e digo: ouves, meu amor?, eu sou 
aquilo que se espera para as coisas, para o tempo -

eu sou a beleza.

Inteira, tua vida o deseja. Para mim se erguem

teus olhos de longe. Tu própria me duras em minha velada

beleza.

Então sento-me à tua mesa. Porque é de ti

que me vem o fogo.

Não há gesto ou verdade onde não dormissem

tua noite e loucura,

não há vindima ou água

em que não estivesses pousando o silêncio criador.

Digo: olha, é o mar e a ilha dos mitos

originais.

Tu dás-me a tua mesa, descerras na vastidão da terra

a carne transcendente. E em ti

principiam o mar e o mundo.

Minha memória perde em sua espuma

o sinal e a vinha.

Plantas, bichos, águas cresceram como religião

sobre a vida - e eu nisso demorei

meu frágil instante. Porém

teu silêncio de fogo e leite repõe a força

maternal, e tudo circula entre teu sopro

e teu amor. As coisas nascem de ti

como as luas nascem dos campos fecundos,

os instantes começam da tua oferenda

como as guitarras tiram seu início da música nocturna.

Mais inocente que as árvores, mais vasta

que a pedra e a morte,

a carne cresce em seu espírito cego e abstracto, 
tinge a aurora pobre,

insiste de violência a imobilidade aquática.

E os astros quebram-se em luz sobre

as casas, a cidade arrebata-se,

os bichos erguem seus olhos dementes,

arde a madeira - para que tudo cante

pelo teu poder fechado.

Com minha face cheia de teu espanto e beleza,

eu sei quanto és o íntimo pudor

e a água inicial de outros sentidos.

Começa o tempo onde a mulher começa,

é sua carne que do minuto obscuro e morto

se devolve à luz.

Na morte referve o vinho, e a promessa tinge as pálpebras

com uma imagem.

Espero o tempo com a face espantada junto ao teu peito

de sal e de silêncio, concebo para minha serenidade

uma ideia de pedra e de brancura.

És tu que me aceitas em teu sorriso, que ouves,

que te alimentas de desejos puros.

E une-se ao vento o espírito, rarefaz-se a auréola,

a sombra canta baixo.

Começa o tempo onde a boca se desfaz na lua, onde a beleza que transportas como um peso árduo se quebra em glória junto ao meu flanco martirizado e vivo.

- Para consagração da noite erguerei um violino, beijarei tuas mãos fecundas, e à madrugada darei minha voz confundida com a tua.

Oh teoria de instintos, dom de inocência, taça para beber junto à perturbada intimidade em que me acolhes. 
Começa o tempo na insuportável ternura com que te adivinho, o tempo onde a vária dor envolve o barro e a estrela, onde o encanto liga a ave ao trevo. E em sua medida ingénua e cara, o que pressente o coração engasta seu contorno de lume ao longe. Bom será o tempo, bom será o espírito, boa será nossa carne presa e morosa. - Começa o tempo onde se une a vida à nossa vida breve.

Estás profundamente na pedra e a pedra em mim, ó urna salina, imagem fechada em sua força e pungência.

E o que se perde de ti, como espírito de música estiolado em torno das violas, a morte que não beijo, a erva incendiada que se derrama na íntima noite - o que se perde de ti, minha voz o renova num estilo de prata viva.

Quando o fruto empolga um instante a eternidade inteira, eu estou no fruto como sol e desfeita pedra, e tu és o silêncio, a cerrada matriz de sumo e vivo gosto.

- E as aves morrem para nós, os luminosos cálices das nuvens florescem, a resina tinge a estrela, o aroma distancia o barro vermelho da manhã. E estás em mim como a flor na ideia e o livro no espaço triste.

Se te aprendessem minhas mãos, forma do vento a cevada pura, de ti viriam cheias minhas mãos sem nada. Se uma vida dormisses em minha espuma, 
que frescura indecisa ficaria no meu sorriso?

- No entanto és tu que te moverás na matéria da minha boca, e serás uma árvore

dormindo e acordando onde existe o meu sangue.

Beijar teus olhos será morrer pela esperança.

Ver no aro de fogo de uma entrega

tua carne de vinho roçada pelo espírito de Deus

será criar-te para luz dos meus pulsos e instante

do meu perpétuo instante.

- Eu devo rasgar minha face para que a tua face

se encha de um minuto sobrenatural,

devo murmurar cada coisa do mundo

até que sejas o incêndio da minha voz.

As águas que um dia nasceram onde marcaste o peso

jovem da carne aspiram longamente

a nossa vida. As sombras que rodeiam

o êxtase, os bichos que levam ao fim do instinto

seu bárbaro fulgor, o rosto divino

impresso no lodo, a casa morta, a montanha

inspirada, o mar, os centauros

do crepúsculo

- aspiram longamente a nossa vida.

Por isso é que estamos morrendo na boca

um do outro. Por isso é que

nos desfazemos no arco do verão, no pensamento

da brisa, no sorriso, no peixe,

no cubo, no linho,

no mosto aberto

- no amor mais terrível do que a vida.

Beijo o degrau e o espaço. O meu desejo traz 
o perfume da tua noite.

Murmuro os teus cabelos e o teu ventre, ó mais nua

e branca das mulheres. Correm em mim o lacre

e a cânfora, descubro tuas mãos, ergue-se tua boca

ao círculo de meu ardente pensamento.

Onde está o mar? Aves bêbedas e puras que voam

sobre o teu sorriso imenso.

Em cada espasmo eu morrerei contigo.

E peço ao vento: traz do espaço a luz inocente

das urzes, um silêncio, uma palavra;

traz da montanha um pássaro de resina, uma lua

vermelha.

Oh amados cavalos com flor de giesta nos olhos novos,

casa de madeira do planalto,

rios imaginados,

espadas, danças, superstições, cânticos, coisas

maravilhosas da noite. Ó meu amor,

em cada espasmo eu morrerei contigo.

De meu recente coração a vida inteira sobe,

o povo renasce,

o tempo ganha a alma. Meu desejo devora

a flor do vinho, envolve tuas ancas com uma espuma

de crepúsculos e crateras.

Ó pensada corola de linho, mulher que a fome

encanta pela noite equilibrada, imponderável -

em cada espasmo eu morrerei contigo.

E à alegria diurna descerro as mãos. Perde-se

entre a nuvem e o arbusto o cheiro acre e puro

da tua entrega. Bichos inclinam-se

para dentro do sono, levantam-se rosas respirando

contra o ar. Tua voz canta 
o horto e a água - e eu caminho pelas ruas frias com

o lento desejo do teu corpo.

Beijarei em ti a vida enorme, e em cada espasmo

eu morrerei contigo. ${ }^{326}$

Este poema não é apenas uma exaltação do amor, simbolizado pelo encontro erótico entre um "eu” e um "tu”, mas é, sobretudo a gestação mesma do amor, especialmente se atentarmos para dois fatores de importância: primeiramente, as referências insistentes ao texto bíblico Cântico do cânticos, registro basilar da narrativa amorosa ocidental; depois pelos efeitos de metalinguagem a respeito dos quais venho insistindo. Nos dois casos, seja pelo vínculo estabelecido com Cântico dos cânticos, seja pela possibilidade de leitura metalinguística, a criação é evidenciada: no caso da conversa com o texto bíblico, a evidência é devida ao fato de ser este um dos textos inaugurais sobre o amor (e, portanto, parcialmente responsável por criar um discurso sobre o amor), e no caso da metalinguagem implicada, a criação é evidenciada pelo fato de que há explicitação do fazer poético/criativo. As relações que pretendo compor, entretanto, não param por aí: deve ser acrescentada a esta rede, a figuração do feminino (alteridade implicada na relação intersubjetiva), responsável por esta gestação poéticoamorosa, mediante a metáfora do ato sexual: tendo em vista a mulher como força geradora, na acepção metalinguística, ela assume o papel de musa, já que é responsável por impulsionar o poema. Passo, portanto, à leitura dos versos, de modo a tentar recompor essa trama complexa acima esboçada.

A começar pelo elo evidente que este poema mantém com o texto bíblico, notase que há a apropriação de uma série de imagens e de procedimentos presentes logo no início do Cântico dos cânticos (que aqui apresento em versão mudada para o Português pelo próprio Herberto Helder): “[Sulamite] Beije-me ele com os beijos da sua boca./ Amor melhor do que o vinho. ${ }^{, 327}$. Ora, a ideia da embriaguez provocada pelo amor,

\footnotetext{
${ }^{326}$ A reprodução do poema (que é também o primeiro livro publicado por Herberto Helder em 1958 pela Editora Contraponto, de Luiz Pacheco) foi feita a partir de Ofício Cantante, Lisboa: Assírio \& Alvim, 2009, p.19-27

327 SALOMÃO. "Cântico dos cânticos" In: HERBERTO HELDER. O bebedor noturno: poemas mudados para o português. Lisboa: Assírio \& Alvim, 2010, p. 28. Outras versões deste mesmo trecho: "Os teus beijos, meu amor, machucam os meus lábios!/ Os beijos da tua boca embriagam mais do que o vinho." - sem atribuição de versos a nenhuma das personagens - (em tradução de Augusto Frederico Schmidt SALOMÃO. Cântico dos cânticos. Rio de Janeiro: Hedra, 1938, p. 27); "Ele me beijará/ com
} 
aparece em mais de um momento em Amor em visita: "Uma mulher com quem beber [grifo meu] e morrer.”; “Beberei sua boca [grifo meu], para depois cantar a morte/ e a alegria da morte."; "Minha memória perde em sua espuma/ o sinal e a vinha [grifo meu]."; "tua carne de vinho [grifo meu] roçada pelo espírito de Deus."; "a flor do vinho [grifo meu], envolve tuas ancas com uma espuma". A ser notado que, em contraposição às interpretações religiosas - investidas de forte teor simbólico -, que espiritualizam e moralizam o amor apresentado em o Cântico dos cânticos ${ }^{328}$, Herberto Helder vai propor que este amor inaugural (tendo em vista o poema como composição em referência explícita ao texto bíblico) seja um amor purificado de todos os pecados, desde que a purificação seja aqui entendida como procedimento que torna pura a erotização e sensualidade de que o amor é dotado. Evidências nesse sentido, seriam as que colhemos em alguns dos versos já transcritos acima, mediante processos de metaforização ( $a$ flor do vinho, em que a flor seria a metáfora do sexo feminino, como está sugerido pelo envolvimento que opera em direção às ancas), ou ainda mediante a qualificação da carne (de vinho), ela mesma divinizada (portanto, purificada), já que roçada pelo espírito de Deus. Tais evidências se tornam ainda mais enfáticas nas seguintes passagens do longo poema de Herberto Helder: "Ele [o corpo da mulher] imagem vertiginosa e alta de um certo pensamento/ de alegria e de impudor [grifo meu]"; "mulher de ventre escarlate (...),/ mulher de pés no branco [grifo meu]" (trecho em que a pureza do branco não é corrompida pelo ventre escarlate, ao contrário: é por ele garantida, como se o ventre fosse o centro donde irradiaria, a um só tempo a paixão e a pureza - originária, instintiva - da própria paixão); ainda sobre a brancura em paralelo com a nudez: "Murmuro os teus cabelos e o teu ventre, ó mais nua/ e branca das mulheres", em outro momento: "a carne transcendente", isto é, a carne, uma vez mediada pelo amor, possibilita ela mesma a sondagem de um mais

beijos de sua boca/ pois melhor teu amor/ que o sabor do vinho" (em tradução de Haroldo de Campos: CAMPOS, Haroldo. "Cântico dos cânticos" In: Éden: um tríptico bíblico. São Paulo: Perspectiva, 2004, p. 113); "Que me beije dos beijos de sua boca,/ Melhores que vinho são teus seios" - em que o primeiro verso é atribuído à Sulamita e o segundo verso é atribuído às "fillhas de Jerusalém") (em tradução de Antonio Medina Rodrigues: SAlOMÃo. Cântico dos cânticos. São Paulo: Hedra, 2008, p. 47). As variações apresentadas permitiriam interpretações diversas, uma vez que enfatizam aspectos distintos, sobretudo na comparação com o vinho (em que a diversidade se manifesta no termo mesmo escolhido na comparação: beijos, amor, seios). Entretanto, será a partir da versão de Herberto Helder - por razões óbvias - que desenvolverei a leitura.

${ }^{328}$ A esse respeito nos informa Adriano Scatolin: "De fato, embora o texto também fosse entendido de maneira literal - leitura predominante sobretudo antes do cristianismo -, os judeus viram no casamento encenado no Cântico a união de Deus com o povo de Israel, por exemplo, ou da Torá com o homem, enquanto os cristãos atribuíram-no à união de Cristo e a Igreja." (SCATOLIN, Adriano. "Introdução" In: SALOMÃO. Cântico dos cânticos. São Paulo: Hedra, 2008, pp. 25, 26). 
além do seu significado puramente denotativo (material), remetendo, portanto, à abstração implicada no sentimento amoroso (abstração que, juntamente com o êxtase, também caracteriza o sentimento religioso). Em Cântico dos cânticos, algumas das linhas de força erótica e sensual que coloco em paralelo: "[Sulamite] O meu amado é como um ramo de mirra/ cravado entre meus seios"329, "[Sulamite] Levou-me o meu amado pelas câmaras da festa,/ e era o amor o estandarte que ele abria sobre mim." ${ }^{330}$, "[Salomão] Teus lábios, um fio de escarlata;"331 " "[Salomão] Como és bela, minha amada, e pura." ${ }^{, 332}$; (a pureza, insisto, como característica que abarca a sensualidade, uma vez que possui a conotação de não ter sido alterada pelos discursos que moralizam o corpo pela ideia de pecado); “[Sulamite] Já o meu amado passa a mão pelo postigo:/ e de súbito estremecem-me as entranhas" ${ }^{333}$ (é o corpo/a carne que reage ao sinal da proximidade do amado); "[Salomão] A curva das tuas coxas é como um colar,/ obra das mãos de um artista./ Abre-se teu umbigo como uma taça redonda,/ em teu ventre, montículo de trigo/ cercado de lírios"334; “[Salomão] As suas feições são como flechas de fogo,/ uma chama de Deus" ${ }^{\text {,33 }}$ - neste último verso importa ressaltar a associação entre fogo (metáfora do amor erótico) e Deus, ele mesmo conotado com propriedades do fogo, em confluência com a sugestão que há pouco propus acerca do êxtase religioso em confluência com o êxtase amoroso (em Herberto Helder: "tu sempre me incendeias.", "Porque é de ti/ que me vem o fogo.").

Curiosa é a divisão de papéis que se estabelece no poema em contraposição ao texto bíblico: no caso do poema a voz da enunciação é a voz masculina (o "eu" ou o sujeito lírico), que por sua vez se dirige a uma mulher (o "tu" ou o "outro" que permite a encenação da relação intersubjetiva), frequentemente anunciada como possuidora do silêncio - a isso voltarei adiante -; enquanto no caso do texto bíblico as vozes feminina e masculina são intercaladas. Ora, isso nos leva a pensar - conforme

\footnotetext{
${ }^{329}$ HELDER, Herberto. "Cântico dos cânticos" In: O bebedor noturno: poemas mudados para o português. Lisboa: Assírio \& Alvim, 2010, p. 29.

${ }^{330}$ Idem, p. 31.

${ }^{331}$ Idem, p. 36.

${ }^{332}$ Idem, 37.

${ }^{333}$ Idem, p. 39.

${ }^{334}$ Idem, p. 45.

${ }^{335}$ Idem, p. 48.
} 
pensaram e complexificaram alguns ensaístas que trouxemos no princípio deste tópico - na alteridade como lugar ocupado predominantemente pela mulher na poética herbertiana, de forma que o desenvolvimento desse tópico será de grande relevância para pensar o amor e a intersubjetividade em $O$ amor em visita.

Vale, entretanto, mencionar duas composições em que há alternância entre as vozes masculina e feminina. Num dos casos, trata-se de um conto, "Duas pessoas", publicado em Os passos em volta, em que a um longo discurso masculino - a partir do qual somos informados de um encontro entre este homem e uma prostituta -, sucede-se outro discurso, igualmente longo, em voz feminina: a voz da prostituta. Curioso aqui é o distanciamento entre este homem e esta mulher - uma vez que os discursos, primeiro o do homem, depois o da mulher, são ambos monólogos interiores que versam acerca da percepção de cada um deles sobre esse encontro sem, entretanto, nunca haver comunicação efetiva/proximidade entre os dois - fato que pode ser interpretado como resultado de uma resistência ao sentimento amoroso (de modo que poderíamos supor, por contraposição, que, caso houvesse amor, haveria comunicação, bem como manifestação intersubjetiva). Suponho que essa resistência possa ser entendida como consequência do foco estar na reflexão da alteridade e não na vivência da relação: o que está em questão é a especulação acerca do outro, de modo que o aspecto relacional/perceptivo/vivencial - que seria possibilitado, caso houvesse a entrega amorosa - acaba sendo desprezado em função de uma tentativa (frustrada) de entendimento. Tal resistência, se manifesta na voz masculina do seguinte modo: "Eis a verdade: sou uma criatura devastada pelo egoísmo (...). Farto de gentes, costumes, acontecimentos." 336 e, em paralelo, do seguinte modo na voz feminina: "Mas eu própria estou cansada, farta das pessoas, os falsos enigmas, as noites em que entro e saio da cama de homens desesperados (...). Poderia amá-lo (...)."337. A respeito do distanciamento, vale enfatizar uma característica relevante presente em ambos os discursos: o estabelecimento de uma identidade masculina em confronto ao estabelecimento de uma identidade feminina, o que pode ser subsumido dos seguintes trechos: "[homem] Estas pequenas prostitutas ficam diante de mim desprovidas de qualidades humanas. Possuem corpo, máquina de algum talento, enquanto a minha

\footnotetext{
${ }^{336}$ HELDER, Herberto. Os passos em volta. Rio de Janeiro: Azougue Editorial, 2005, p. 122.

${ }^{337}$ Idem, p. 128.
} 


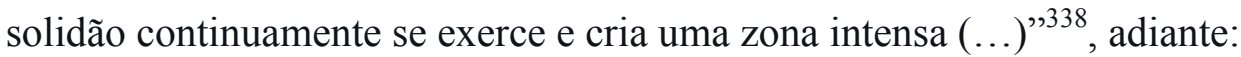

[homem] Não percebe, ou espera que eu faça surgir, dentre a massa de humilhação e marginalidade da sua vida, essa trêmula, veloz alegria. Eu que sou um homem, que possuo a ambígua faculdade da doçura viril, e posso exibir a comoção perante a beleza, mesmo a fortuita e frágil beleza humana. Mas estaco. Sou cruel? Ou frio. Para o caso tanto faz. 339

E diz ainda: "[homem] E ela elevava então para mim os grandes olhos onde o terror se diluía, os olhos que recebiam e devolviam uma luz maior. Eu poderia dizer: o teu cabelo. Ou: a tua mão. Ou ainda: tu. ${ }^{, 340}$ (importa ressaltar que o reconhecimento subjetivo da mulher pelo homem, tal como aqui aparece num rápido momento de realização intersubjetiva - pois que ao receber luz dos olhos do homem, a mulher devolveria luz maior, de modo que há comunicação - ocorre pela hesitação do homem em dizer "tu", e neste caso, dizer "tu", equivaleria a dizer "o teu cabelo" ou "a tua mão", isto é a existência mais uma vez atestada pelo corpo manifesto). Em paralelo, seguem passagens do monólogo interior feminino:

[mulher] Estou farta dos homens, quase nunca tenho prazer em ir para a cama com eles (...) acho-os absurdos com o seu sofrimento mal oculto atrás de uma simulada virilidade (...). Os homens imaginam, suponho, que me sinto humilhada na minha profissão e que existem em mim, sempre prontos, um apelo, uma súplica. Mas não. ${ }^{341}$

Pouco adiante:

[mulher] É um homem que eu deveria socorrer. Tento mostrar-lhe que há algures, nas nossas possibilidades humanas, uma zona onde a vida se regenera. Eu própria gostaria de ser mais alegre e generosa, mas hesito nos meus impulsos. Existe nos homens essa insuportável fatuidade, um orgulho estúpido e, lá no fundo, uma espécie de condição própria inalcançável, repugnante. ${ }^{342}$

E, por fim, o momento em que a prostituta e a mãe coincidem, como caracterização dessa ideia herbertiana de feminino:

\footnotetext{
${ }^{338}$ Idem, p. 121.

${ }^{339}$ Idem, p. 123.

${ }^{340}$ Idem, pp. 125, 126.

${ }^{341}$ Idem, p. 127.

${ }^{342}$ Idem ibidem.
} 
[mulher] É um inimigo. Estes homens embulham-nos. Exploram a fonte maternal de que somos dotadas, ficam ali sugando nosso leite, e deixam-nos completamente vazias. Raça de exploradores. (...). Cegueira maternal, furiosa força de doçura que me empurra para o homem, para a sua perpétua e louca orfandade. ${ }^{343}$

Considerando ainda os dois discursos em paralelo, nota-se que, se a virilidade é característica que, do ponto de vista masculino, permite que se considere a condição da mulher/prostituta, como condição de humilhação, no entanto, do ponto de vista feminino, a virilidade masculina é algo que apenas dissimula o sofrimento do homem e portanto é apenas uma máscara para sua fraqueza, e, ao contrário do que supõe o homem, a mulher-prostituta não se sente de fato humilhada pela suposta "marginalidade da sua vida". Há entretanto, um ponto de coincidência entre os dois discursos, em que a mulher acaba por sobressair-se: trata-se deste poder de diluir o terror como característica própria das mulheres (conforme aparece no discurso do homem), que, no discurso da mulher aparece como característica maternal, impulso de socorrer os homens de sua condição de orfandade. Ora, essa percepção da mulher/prostituta/mãe permeia toda a obra herbertiana e, conforme interpreto, trata-se de uma tentativa de absolutizar o princípio da alteridade feminina, mediante características do sagrado (em referência ao Cântico dos cânticos) e do poder gerador, em que a mulher seria a musa responsável pela salvação do sujeito na elaboração criativa, conforme será mais detalhadamente desenvolvido a seguir.

Além do conto acima referido, há uma segunda composição em que intercalamse a voz masculina e a voz feminina: trata-se de poema publicado em $A$ faca não corta o fogo que começa com os seguintes versos: "não some que eu lhe procuro, e lhe boto/ faca à garganta". Diferentemente do conto, no poema em questão, o amor atravessa as subjetividades ali enunciadas de modo a promover a intimidade suposta na relação intersubjetiva, a ponto de ser a intimidade, tal como aqui me refiro, sinônimo de uma ausência de fronteiras precisas entre "eu" e "outro". A despeito da diferença apontada (que muito vem confirmar sobre o poder do amor de diluir os limites do sujeito - que de indivíduo/indivisível passaria a "divíduo"/divisível, por assim dizer), vale atentar para a coincidência de que ambos se revestem: também aqui, a mulher que detém a voz é uma prostituta, assim referida pelo discurso inicial em que o homem é o enunciador:

${ }^{343}$ Idem, pp. 128, 129. 
"a puta de sua vida,/ alta criatura chegada na terra muda"344, e a seguir: "¿que é isso: puta?/ pequena, se fôr às raízes latinas,/ mas tudo cresceu de tamanho, grão de cobre/ (...)/ que besteira de lhe chamar puta,/ de pequena,/ ou mesmo se the chame de grande puta" $^{345}$, e em manifestação da fusão intersubjetiva:

“(...) que esse

beijo que agora coméço é para não

acabar nunca,

não queira que eu vá crer em Deus e pedir milagre,

fique, tão puta quanto seja, com

seu jeito de água marítima,

balançando, menininha, barca bêbada,

mas enredada em mim como alimento luminoso,

ah se incendeie a gente um do outro [grifo meu], que morte

ou vida mais total

não há, não some, amor

da puta de minha vida indistinta,

noite onde me envolvo para sempre,

que simples, contudo, com tudo isso, que é se cruzar com o mundo,

fique, fica junto, funda fêmea, que você já me está

fundada no sangue desde que outrora, e agora, e na hora da nossa [grifo meu]"346

E assim, com o escandaloso silêncio que a ausência da palavra "morte" provoca, mediante a brusca interrupção do sintagma que encerra a oração católica "Ave Maria" ("agora e na hora de nossa morte"), o poema segue com a enunciação feminina - outra diferença em relação ao conto: a mulher/puta, neste caso, dialoga explicitamente com a enunciação do homem: "porque o amor é mais forte que a eternidade dos mortos", "(...) me ata de boca e sexo",

\footnotetext{
${ }^{344}$ HELDER, Herberto. Oficio Cantante, Lisboa: Assírio \& Alvim, 2009, p. 544.

${ }^{345}$ Idem, p. 545

${ }^{346}$ Idem, p. 546.
} 
“(

e com teus braços terríveis me cruza toda,

que ainda me está doendo do peso de seu beijo

na risca rosa no meio de virilha até virilha,

e entra em mim e que as coxas me estremeçam,

te mete inteiro

por boca e cu e côna adentro,

que os que louvam a Deus esse Deus os devora,

como a fêmea louva-a-deus ao macho, puta,

$(\ldots)$

¡oh noche, que juntaste amada con amado, amado en la amada transformado!

: inexplicável: claro" ${ }^{347}$

Não mais um questionamento acerca da moralização dos papéis sociais prostituição/feminilidade e virilidade/masculinidade, como no conto "Duas pessoas" (embora a moralização já ali se desconstruísse mediante a complexificação dos monólogos subjetivos), mas a assunção da realização íntima/intersubjetiva, como resultado de uma subversão moral que deriva da união carnal - e como subversão moral é que leio essa espécie de sacralização da "puta", uma vez que se avizinham os versos em que os vocábulos côna, $c u$ e Deus são mencionados todos em função do ato amoroso, somando-se a referência à virgem Maria mediante a apropriação do trecho final da oração ao fim do poema. Os papéis encenados pelo gênero masculino e feminino estão fundidos corporalmente (fusão coroada ao fim do poema mediante a variação do verso de San Juan de la $\mathrm{Cruz}^{348}$ ), de modo que a intersubjetividade é aqui um fato decorrente do ato amoroso com toda a subversão que ele implica: contra a moral (como já explicitado) e contra a razão, conforme o verso final do poema, “: inexplicável: claro". Sem pretender uma referencialização exaustiva do tema na poética herbertiana, vale trazer ainda uma passagem de Flash sobre a fusão decorrente

${ }^{347}$ Idem, p. 547, 548.

${ }^{348}$ No original: “ ¡oh noche, que juntaste/ Amado con amada,/ amada en el amado transformado!” (DE LA CRUZ, San Juan. Poesía Completa y comentários en prosa. Barcelona: Editorial Planeta, 1989, p. 3). Curiosa é a inversão entre amado e amada promovida por Herberto Helder; não apenas curiosa( (o que facilmente se justificaria pelo fato de que o sujeito da enunciação poética é, em $\mathrm{HH}$, masculino, enquanto em San Juan de la Cruz, o sujeito é feminino), mas reveladora de outra inversão mais significativa: a inversão entre alma e corpo: se no poema de San Juan de la Cruz, a "Alma" é a 
do ato sexual/ amoroso, em que o próprio poema é resultado dessa fusão ${ }^{349}$ : "E queimavas-me a boca, pura/ colher de ouro tragada/viva. Brilhava-te a língua./ Eu brilhava./ Ou que então, entrecravados num só contínuo nexo,/ nascesse da carne única/ uma cana de mármore./ (...) Lábios anónimos, no hausto de árdua fêmea e macho/ anelados em si, criassem um órgão novo entre a ordem./ (...) E éramos, nós, o fausto violento, transformador/ da terra.// Nome do mundo, diadema." ${ }^{350}$.

Trago novamente, para este contexto interpretativo, algumas passagens de Apresentação do rosto já evocadas em outro momento, que evidenciam a feminilidade como alteridade: "Em mim, uma alegria tão forte que se torna necessário fazer qualquer coisa. Tiro do bolso o meu pequeno canivete e, no braço nu, traço um golpe fundo. Vejo o sangue correr, o meu sangue. ${ }^{\text {„351 }}$ e mais:

Comigo foi assim, pensa ele: golpeei o braço, expus-me, criança doce e dramática em frente do espanto e da comoção das mulheres, caí no abismo, ressuscitei sob a delicadíssima atenção feminina, cresceram-me os braços e as pernas, insinuou-se em mim um novo ritmo, soube que ultrapassei um perigo e fiquei de uma outra maneira diante de tudo (...). Depois diz: aconteceu-lhe o mesmo a ela, mas de um modo particular (...). Quanto ao sangue de uma irmã de doze anos que de repente pára de comer ameixas e olha a parede e fica em pânico e grita e atrai as mulheres e é arrastada para o fundo da casa começo a saber uma pequena coisa. Tenho medo. ${ }^{352}$

O sujeito, como dissemos em outro momento, se situa nos limites da subjetividade feminina, no sentido mesmo de não poder abarcá-la desde "o lado de dentro" (o 'lado dentro", ou seja, a perspectiva masculina, em contraposição ao "lado

enunciadora do poema (segundo declaração do próprio poeta: "Cuenta el alma en esta primera canción el modo y manera que tuvo en salir, según el afección, de sí y de todas las cosas, muriendo por verdadeira mortificación a todas ellas, a sí misma, para venir a vivir vida de amor Dulce y sabrosa en Dios. Y disse que este salir de sí y de todas las cosas fue En una noche oscura, que aqui entende por la contemplación purgativa, como después se dirá, la cual passivamente causa en el alma la dicha negación de sí misma y de todas las cosas." (Idem, p. 47)), no poema de Helder o corpo é protagonista, e por meio dele é que o êxtase divino se manifesta encarnado na figura do amado ("a fêmea louva-a-deus ao macho").

${ }^{349}$ Vide os termos metalinguísticos: boca, língua, nome, a respeito dos quais não me demorarei neste momento, uma vez que serão evidenciados na sequência da análise.

${ }^{350}$ HELDER, Herberto. Oficio Cantante, Lisboa: Assírio \& Alvim, 2009, pp. 362, 363.

${ }^{351}$ HELDER, Herberto. Apresentação do rosto. Lisboa: Ed. Ulisseia, 1968, p. 46. Essa problemática está mais amplamente deselvolvida por mim em artigo dedicado a uma leitura de Apresentação do Rosto livro (Cf. JOAQUIM, Ana Cristina. "O escritor no espaço da obra: o rosto caligrafado - uma leitura de Apresentação do Rosto, de Herberto Helder” In: Revista do CESP, Belo Horizonte, v. 34, n. 52, p.77-99, 2014).

${ }^{352}$ Idem, p. 60. 
de fora", que seria a perspectiva feminino) nem mediante o conhecimento que apenas a intimidade subjetiva proporciona (intimidade subjetiva ou ipseidade, para evidenciar a metáfora da existência própria que a imagem do sangue atualiza). Curioso é notar de que maneira essa alteridade ocorre de modo diverso, em $O$ amor em visita, já que neste último caso situa-se numa fronteira sutil entre a delimitação entre "eu" e "outro" e a fusão mesma dos dois polos relacionais, uma vez que o amor entre dois adultos (importa notar que já não se trata mais de um menino que se apavora diante da descoberta da própria masculinidade, como no caso de Apresentação do Rosto), funcionaria aqui como um catalizador intersubjetivo.

Ora, esta espécie de oscilação entre separação e união nota-se, no longo poema, mediante uma gradação em que, no princípio há uma clara distinção entre identidade e alteridade, como notamos nos seguintes trechos iniciais do poema: "Dai-me uma jovem mulher com sua harpa de sombra/ e seu arbusto de sangue. Com ela/ encantarei a noite.", "Uma mulher com quem beber e morrer.", "seu corpo arderá mansamente sob os meus olhos palpitantes.": nos três casos, a mulher é alguém, o "outro" em quem o sujeito "eu" encontra companhia, ou mesmo, dois corpos distintos cujos limites ainda estariam estabelecidos pelo olhar. Num segundo momento ocorre uma espécie de fusão entre o princípio feminino e elementos diversos do mundo (de modo que o "eu" enunciador é a única entidade que se mantém alheia, por assim dizer, dessa espécie de harmonia universal): "Dai-me uma folha viva de erva, uma mulher./ Seus ombros beijarei, a pedra pequena/ do sorriso de um momento.", “À tona da sua face se moverão as águas,/ dentro da sua face estará a pedra da noite.”, em que erva e mulher tornam-se sinônimos, assim como o ombro da mulher e a pedra pequena e a face da mulher é representada como se fundida com o movimento das águas e com a pedra da noite; e mais: "E os astros quebram-se em luz sobre/ as casas, a cidade arrebata-se,/ os bichos erguem seus olhos dementes,/ arde a madeira - para que tudo cante/ pelo teu poder fechado.", de modo que o canto é derivado dessa unificação promovida entre astros, casas, cidade, bichos, madeira em função do "poder fechado" da amada (sobre o "poder fechado", voltarei com mais atenção no momento de falar sobre o silêncio). Novamente, o paralelo com o Cântico dos cânticos: "[Sulamite] Eu sou a rosa de Saron, o lírio dos vales”353 " "[Salomão] Teus olhos são duas pombas, atrás do véu. Tua cabeleira é um rebanho de cabras,/ descendo pelas vertentes de Galaad./ Teus dentes,

\footnotetext{
${ }^{353}$ HELDER, Herberto. "Cântico dos cânticos" In: O bebedor noturno: poemas mudados para o português. Lisboa: Assírio \& Alvim, 2010, p. 31.
} 
rebanho de ovelhas tosquiadas/ que sobem do bebedouro,/ duas a duas, sempre juntas." ${ }^{354}$. Ora, a evidente metaforização do discurso em Cântico dos cânticos, eu aqui aproximo, semanticamente, da expansão promovida pelo amor em $O$ amor em visita, de modo que há, nos dois casos, esse poder de tudo abarcar contido no amor.

Por fim, o "eu" funde-se por completo ao outro, mediante o ato amoroso (vale atentar para a fusão como decorrência da interpenetração dos corpos no ato sexual como já atentamos inicialmente): "Digo: eu sou a beleza, seu rosto e seu durar. Teus olhos/ transfiguram-se, tuas mãos descobrem/ a sombra da minha face. Agarro tua cabeça/ áspera e luminosa, e digo: ouves, meu amor?, eu sou/ aquilo que se espera para as coisas, para o tempo -/ eu sou a beleza./ (...) Tu própria me duras em minha velada/ beleza.", "boa será nossa carne presa e morosa./ - Começa o tempo onde se une a vida/ à nossa vida breve.”, "E estás em mim como a flor na ideia/ e o livro no espaço triste.", "serás uma árvore/ dormindo e acordando onde existe o meu sangue.", “- Eu devo rasgar minha face para que a tua face/ se encha de um minuto sobrenatural", "As águas que um dia nasceram onde marcaste o peso/ jovem da carne aspiram longamente/ a nossa vida. As sombras que rodeiam/ o êxtase, os bichos que levam ao fim do instinto/ seu bárbaro fulgor, o rosto divino/ impresso no lodo, a casa morta, a montanha/ inspirada, o mar, os centauros/ do crepúsculo/ - aspiram longamente a nossa vida.". Conforme as palavras de Michel Leiris: “(...) o amplexo amoroso deriva seu valor desconcertante do fato de ser o meio pelo qual, ao menos por um curto lapso de tempo, um sujeito pensante pode julgar-se unido materialmente ao mundo, resumido num único ser vivo. ${ }^{355}$.

É mesmo dessa fusão que parece nascer o poema: não apenas porque o encontro amoroso é o tema motriz do poema em questão, mas, especialmente, porque a proximidade/fusão deste "eu" com a musa/mulher ("outro") vai "dar à luz" ao poema que, como venho insistindo, pode ser considerado como o resultado material do encontro amoroso. Daí as referencias metalinguísticas que o poema oferece, como se a selar o resultado - poema - do elo promovido no ato amoroso. Mais além, o próprio poema como ato amoroso. Logo no princípio do poema, lemos: "Cantar? Longamente cantar.", leio o canto, assim como as demais alusões musicais, como referências diretas

\footnotetext{
${ }^{354}$ Idem, p. 36.

${ }^{355}$ LEIRIS, Michel. Espelho da tauromaquia. São Paulo: Cosac \& Naify, 2001, p. 48.
} 
à composição do poema, que, no caso deste verso específico, acentuam-se, pelo uso do advérbio "longamente", que acaba por caracterizar o modo de composição deste mesmo longo poema; "os bordões da melodia", "cantarei seu sorriso ardendo,/ suas mamas de pura substância, a curva quente dos cabelos.", no caso destes versos, é curioso que a enunciação do verbo cantar, atualiza ele mesmo aquilo que supõe - daí a metalinguagem tão evidente - funcionando, de algum modo, como os verbos performativos "prometer" e "jurar". o Canto - neste caso, como nos demais - também deve ser lido como manifestação do amor erótico ele mesmo; "Dai-me um torso dobrado pela música", "tua boca penetra a minha voz como a espada/ se perde no arco.”, com especial atenção para a metáfora sexual fundida à metáfora da escrita, em que os vocábulos "boca" e "voz" remeteriam ao ofício poético e o mesmo vocábulo "boca" junto com os vocábulos "espada" e "arco" remeteriam ao ato sexual), "invento para ti a música" (como proposta de paráfrase: invento para ti o poema); "e à madrugada/ darei minha voz confundida com a tua./ Oh teoria de instintos, dom de inocência,/ taça para beber junto à perturbada intimidade/ em que me acolhes.”, a madrugada como momento em que os amantes, desobrigados das tarefas sociais, podem deixar agir os instintos e a inocência - que em outro momento apareceu como pureza -, e o poema como resultado das vozes confundidas), "Para consagração da noite erguerei um violino", aqui, o ato de erguer lido em remissão ao pênis ereto pela excitação amorosa), "ergue-se tua boca/ ao círculo de meu ardente pensamento." .

Tais referências metalinguísticas também encontram-se em paralelo no Cântico dos cânticos: "Cantaremos teu amor mais que o vinho",356 "[Sulamite] deixa-me ouvir a tua voz."357, "[Sulamite] Porque a tua voz é clara"358, "[Sulamite] E a sua voz é branca, e tudo/ é magnífico"359 "“Salomão] tuas palavras, um vinho delicado",360.

\footnotetext{
${ }^{356}$ HELDER, Herberto. "Cântico dos cânticos" In: O bebedor noturno: poemas mudados para o português. Lisboa: Assírio \& Alvim, 2010, p. 27. Importa observar que Herberto Helder não indica o enunciador dessa fala (que não pode ser atribuída à Sulamita, uma vez que o sujeito está na primeira pessoa do plural e se dirige a um "tu" - supostamente a Sulamita -), de modo que interpretamos a fala como sendo enunciada pelos "irmãos de Sulamite" (o coro que aparecerá em outros momentos do texto). Nas outras traduções há grandes variações nesta fala, entretanto, não recorro a elas, uma vez que não se trata de buscar a versão mais "fiel" ao original, mas de compor uma leitura a partir da versão do próprio Herberto Helder.

${ }^{357}$ Idem, p. 32.

${ }^{358}$ Idem, p. 33.

${ }^{359}$ Idem, p. 41.

${ }^{360}$ Idem, p. 45.
} 
Nesse mesmo sentido é que a "mulher" ganha força de absolutização na poética herbertiana, uma vez que sendo mãe e prostituta, é também a musa geradora, responsável pela criação da vida no poema (de acordo com os versos lidos há pouco, em que a metalinguagem ressalta a potencialidade feminina na intersubjetividade amorosa), uma vez que o poema nasce dela: "E quando gela a mãe em sua distância amarga, a lua / estiola, a paisagem regressa ao ventre", "Toco o peso da tua vida: a carne que fulge, o sorriso,/ a inspiração.”, "E em ti/ principiam o mar e o mundo.”, "e tudo circula entre teu sopro/ e teu amor. As coisas nascem de ti/ como as luas nascem dos campos fecundos,/ os instantes começam da tua oferenda/ como as guitarras tiram seu início da música nocturna.”, "Começa o tempo onde a mulher começa,/ é sua carne que do minuto obscuro e morto/ se devolve à luz.", "- No entanto és tu que te moverás na matéria/ da minha boca, e serás uma árvore/ dormindo e acordando onde existe o meu sangue.", “devo murmurar cada coisa do mundo/ até que sejas o incêndio da minha voz". Ora, esse poder da palavra criadora aparece também nos poemas IV e V de Musas cegas, de modo que no poema IV (precedente) esse poder é diretamente associado à mulher: "Eu olho, e a mulher é a palavra", "A mulher da palavra. A Palavra." "361, e no poema V (posterior), esse poder alcança o sujeito do poema: “(...) Dizem: ele é uma palavra./ E chega o verão, e eu sou exatamente uma Palavra." ${ }^{\text {362 }}$

A metalinguagem é, portanto, indissociável da imagem da mulher que sendo a mãe geradora (responsável pela criação do mundo/poema), e a prostituta (responsável pela pulsão vital) é, por conseguinte, a musa inspiradora. Como bem observou Jorge Fernandes da Silveira: "[em relação a uma primeira mãe camoniana](...) Herberto Helder filia-se a uma segunda mãe de "valor universal". E, por isso, a mãe do seu texto não está presa aos grilhões da História que condenam Tareja. Literatura chama-se ela, sabemos." $" 363$.

Da pulsão de vida à pulsão de morte exatamente como visto no capítulo anterior mediante leitura do poema "Sou eu, assimétrico, artesão, anterior" e mediante o comentário de Silvina Rodrigues Lopes e Luis Maffei, isto é, morte e vida como participantes de um mesmo movimento circular, de acordo com as palavras do próprio

\footnotetext{
${ }^{361}$ HELDER, Herberto. Ofício Cantante, Lisboa: Assírio \& Alvim, 2009, p. 84.

${ }^{362}$ Idem, p. 87.

${ }^{363}$ SILVEIRA, Jorge Fernandes da. "O Amor Cru: Herberto Helder e Camões ou As Duas Mães" In: Verso com verso. Coimbra: Angelus Novus, 2003, p.88.
} 
Herberto Helder no texto "O quarto", em Os passos em volta: “- Talvez creia - disse eu - que vida e morte se abram uma para outra, se alimentem mutuamente. Que seja cada uma delas uma espécie de duplo da outra. Se animem e, por assim dizer, se justifiquem e signifiquem entre si." ${ }^{364}$. Tendo em vista tanto a circularidade em questão, quanto a mulher como pulsão de vida, como explicitado há pouco, torna-se fácil estabelecer o elo entre mulher, morte e silêncio. Por esse motivo é tão recorrente a imagem que lemos na versão de Herberto Helder do Cântico dos cânticos: "Horto fechado és tu, minha irmã, minha amada, / horto fechado, fonte secreta."365, em Amor em visita: "Estás profundamente na pedra e a pedra em mim, ó urna/ salina, imagem fechada em sua força e pungência.”, ainda: "e tu és o silêncio, a cerrada/ matriz de sumo e vivo gosto.", e também no poema de A faca não corta o fogo que há pouco mencionamos, "não some, que eu lhe procuro...": "porque você é tão cerrada em sua vida própria”. Ora, nos três casos, a mulher é fechada (horto fechado, imagem fechada, a cerrada matriz de sumo, cerrada em sua vida própria), de modo que tal qualificação pode ser lida na direção de um circuito completo, como defendo ser a ideia de vida e morte, em Herberto Helder ${ }^{366}$. A seguir, os versos de $O$ amor em visita: "Uma mulher com quem beber e morrer.", "Em cada mulher existe uma morte silenciosa.", "transportadora/ da morte e da alegria.", "Beberei sua boca, para depois cantar a morte/ e a alegria da morte.", "Então cantarei a exaltante alegria da morte.", "o silêncio criador", "teu silêncio de fogo e leite repõe a força/ maternal", "ao teu peito/ de sal e de silêncio, concebo para minha serenidade/ uma ideia de pedra e de brancura.", "estamos morrendo na boca/ um do outro", e, por fim, o verso com que se encerra o poema e que aparecerá, nas quatro estrofes precedentes, como se a marcar o ritmo do circuito perpétuo: "Beijarei em ti a vida enorme, e em/ cada espasmo/ eu morrerei contigo". Ora, silêncio e morte, como duplos (de acordo com o termo usado pelo próprio Herberto Helder) da palavra criadora/poema e da vida: tudo isso num ciclo completo e perfeito figurativizado pela imagem da mulher, o "outro" em relação ao “eu” (sujeito lírico) que, na relação intersubjetiva, são mediados pelo amor, este motor que faz o circuito girar.

\footnotetext{
${ }^{364}$ HELDER, Herberto. Os passos em volta. Rio de Janeiro: Azougue Editorial, 2005, p. 111.

${ }^{365}$ HELDER, Herberto. "Cântico dos cânticos" In: O bebedor noturno: poemas mudados para o português. Lisboa: Assírio \& Alvim, 2010, p. 37.

${ }^{366}$ Com exceção para os dois últimos livros, conforme apontei no capítulo precedente.
} 
Vale também pensar a morte, nesse contexto, como metáfora da aniquilação do indivíduo (no sentido do indivisível) que deve abdicar da sua identidade subjetiva e, portanto, impermeável, para se deixar atravessar pelo "outro" por força do amor, de modo que fundir-se a outro ser é, de algum modo, morrer como indivíduo. É nesse sentido que leio o seguinte trecho de Octavio Paz: "O amor não vence a morte, mas a integra na vida (...) O amor é um regresso à morte, ao lugar de reunião.”367 e, mais adiante:

Nós nos perdemos como pessoa e nos recobramos como sensações. À medida que a sensação se faz mais intensa, o corpo que abraçamos se faz mais e mais intenso. Sensação de infinitude: perdemos corpo nesse corpo. O abraço carnal é o apogeu e a perda do corpo. Também é a experiência da perda da identidade, dispersão de formas em mil sensações e visões, queda numa substância oceânica, evaporação da essência. ${ }^{368}$.

Também Bataille (eu diria até: sobretudo Bataille) pensa as intensidades envolvidas entre erotismo e morte: "O erotismo abre para a morte. A morte abre para a negação da duração individual. Poderíamos, sem violência interior, assumir uma negação que nos leva ao limite de todo o possível?"369, e pensa-as mesmo como uma vivencia da inescapável violência.

Esta seria, entretanto, apenas uma das acepções da morte pensada conjuntamente ao amor, uma vez que conforme afirma Michel Leiris, no estado de paixão, a morte ela mesma é transformada em volúpia:

Incorporar a morte à vida, torná-la de certa maneira voluptuosa (como o gesto do torero conduzindo suavemente o touro nas dobras de sua capa ou de sua muleta), tal deve ser a atividade desses construtores de espelhos, quero dizer: de todos aqueles que têm por propósito mais urgente agenciar alguns desses fatos que podemos tomar por lugares onde o homem tangencia o mundo e a si mesmo, que portanto nos alçam ao nível de uma plenitude portadora de sua própria tortura e de sua própria derrisão. ${ }^{370}$

Para finalizar essa leitura do amor na intersubjetividade entre homem e mulher, tal como ocorre em Herberto Helder, é valiosa uma informação intertextual: trata-se de

\footnotetext{
${ }^{367}$ PAZ, Octavio. A dupla chama: amor e erotismo. São Paulo: Siciliano, 1994, p. 130.

${ }^{368}$ Idem, p. 183.

${ }^{369}$ BATAILLE, Georges. O erotismo. São Pulo: L\&PM, 1987, p. 23.

${ }^{370}$ LEIRIS, Michel. Espelho da tauromaquia. São Paulo: Cosac \& Naify, 2001, p. 75.
} 
um texto publicado em 1898 por Alfredy Jarry, intitulado $O$ amor em visitas (L'amour en visites). A coincidência do título me levou à leitura e consequente comparação do poema de Herberto Helder, com a série de pequenas histórias de que se compõe o livro de Jarry. Tal comparação, entretanto, resultou numa leitura contrastiva: se Herberto Helder vai colocar a mulher na cena amorosa, como uma espécie de mulher absoluta e responsável pela criação, Alfred Jarry, diferentemente, apresenta uma série de mulheres que representam "tipos sociais" (a prostituta, a velha, a duquesa, a criança e a noiva $^{371}$ ), às quais o protagonista, Lucien, visita - cada uma das pequenas histórias é uma cena de visitação às respectivas mulheres -, e as mulheres acabam por ser o veículo de uma visão um tanto sarcástica sobre o amor. O amor, em Jarry, é, portanto, bastante diverso do amor em Herberto Helder: no primeiro, uma diversidade de mulheres (o plural do título se justifica: $O$ amor em visitas), diante das quais o protagonista se frustra e nunca chega de fato à realização amorosa; no segundo uma única mulher e absoluta (a variação do título - singular -, possivelmente apropriado de Jarry, diz muito da perspectiva amorosa herbertiana), a mulher condutora do amor que possibilita que este alcance o sujeito lírico: há realização amorosa.

A mulher/puta/musa/mãe criadora em Herberto Helder, conforme a leitura precedente, é a mulher absoluta e tal caracterização, entretanto, não a torna uma abstração, ela é sobretudo corpo: "Mulher quase incriada, mas com a gravidade/ de dois seios, com o peso lúbrico e triste/ da boca.". O peso ou a gravidade por meio do qual se manifesta sua imanência, muito nos diz do amor enquanto realização entre dois corpos e realização poética (isto é, tornar o amor real pela materialidade do poema), conforme as palavras de Octavio Paz:

O amor humano, quer dizer, o verdadeiro amor, não nega o corpo nem o mundo (...). O amor é amor não a este mundo, mas sim deste mundo; está atado à Terra pela força da gravidade do corpo, que é prazer e morte. Sem alma - ou como queira se chamar a esse sopro que faz de cada homem e de cada mulher uma persona - não há amor, mas tampouco ele existe sem corpo. Pelo corpo o amor é erotismo e assim se comunica com as forças mais vastas e ocultas da vida. Ambos, o amor e o erotismo - dupla chama - se alimentam do fogo original: a sexualidade. ${ }^{372}$

\footnotetext{
${ }^{371}$ Cf. JARRY, Alfred. O amor em visitas. Lisboa: \& etc, 2003.

${ }^{372}$ PAZ, Octavio. A dupla chama: amor e erotismo. São Paulo: Siciliano, 1994, p. 185.
} 
Por fim, cito estes versos de $O$ amor em visita: "De meu recente coração a vida inteira sobe,/ o povo renasce,/ o tempo ganha a alma.", e retomo a citação de Breton para fazer a transição de leitura em direção aos poemas de Cesariny, quem, mais do que qualquer outro, se pronunciou acerca das responsabilidades envolvidas no amor: "Sempre que um homem ama, nada o pode impedir de empenhar, juntamente com a sua, a sensibilidade de todos os outros homens. Para não desmerecer deles, é sua obrigação empenhá-la a sério." ${ }^{\text {373 }}$.

${ }^{373}$ BRETON, André. Amor Louco. Lisboa: Editorial Estampa, 1971, p. 104. 


\subsection{Mário Cesariny e o amor em trânsito}

Tendo em vista a diversidade implicada nas figurações do amor na vasta criação de Mário Cesariny, creio que me cabe traçar um eixo gradativo que, ao que parece, cumprirá com o objetivo de complexificar a sua visão de mundo suposta no conflito que é o cerne do surrealismo: mundo factual (normalizado pelas padronizações binárias supostas pela razão - incluindo-se aqui as normas morais) versus mundo surreal (constante subversão que se destina a um "mais além" suposto nas (im)possibilidades revolucionárias de que as afecções humanas seriam dotadas). Se atento para os dois extremos dessa gradação, a saber: condições de partida dadas pela estrutura edificante do real - por um lado - e ideal surrealista como mote condutor da criação - por outro lado - é porque acredito que o próprio Cesariny manifesta enorme lucidez nos modos de transitar de um a outro polo, pois que Cesariny situa-se num entremeio: inevitavelmente condicionado pela realidade factual de partida, e incansavelmente motivado pelo ideal a ser alcançado.

Ademais, em conformidade com o tópico de leitura anterior, em que enfatizamos os modos de elaboração intersubjetiva tendo em vista as figurações de gênero (homem e mulher) na poética herbertiana; para o caso da poética de Cesariny, importa pensar essas mesmas figurações, considerando-se uma tentativa de atravessamento das identidades operada pelo seu viés.

Em poema que dá título a antologia de seus "poemas maiores", publicada um ano após sua morte (como já referido anteriormente), Cesariny escreve essa espécie de manifesto em direção a "uma grande razão": "Falta por aqui uma grande razão", diz ele, "uma razão que não seja só uma palavra/ ou um coração/ ou um meneio de cabeças após o regozijo",374 e, mais adiante: "faltas tu faltas tu/ falta que te completem/ou destruam/ não da maneira rilkeana vigilante mortal solícita e obrigada/ - não, de nenhuma maneira resultante!/ nem mesmo o amor/ não é o amor que falta/ (...)// [falta] que todos os amores palavras propensões sistemas de palavras e de propensões/ se comam a si mesmos" ${ }^{375}$. Em poema que dá a sequência de leitura na antologia em questão, há os seguintes versos: “como se o nosso louco amor louco/ estivesse cheio de

\footnotetext{
${ }^{374}$ CESARINY, Mário. Uma grande razão: os poemas maiores. Lisboa: Assírio \& Alvim, 2007, p. 25.

${ }^{375}$ Idem, pp. 25, 26.
} 
razão" 376 . Ora, entre o amor louco e a razão, esta "grande razão", de tal modo necessária para que qualquer ideal se cumpra, a ponto de subverter a ideia de razão ou de amor como autossuficientes: amor, ao que tudo indica, há. O que parece faltar é uma grande motivação subversiva que rompa com os limites bem comportados, vigilantes, mortais, que rompa com a ideia mesma de limite, rompimento tal que provocaria o atravessamento supremo de tudo em relação a tudo. Eis o ideal surrealista trasvestido com o vocábulo (razão) que o próprio surrealismo fervorosamente combateu. Não creio, entretanto, que seja possível haver qualquer engano, já que é da "grande razão" que aqui se fala, aquela capaz de implodir toda a organização bemcomportada ou sistematização dos sentidos para afirmar (conforme o poema "a antónio maria lisboa"):

\section{"O amor é um sentido! O amor é um sentido! \\ O AMOR É UM SENTIDO!}

O amor é uma chave que deve perder-se, 377

Ora, de que modo ler os versos precedentes? O amor como um sentido que se deve perder, arrisco, em direção aos sentidos vários que poderiam ser encontrados? “ $\mathrm{O}$ AMOR REDIME O MUNDO diziam eles/ mas onde está o mundo senão aqui?’”378, são os versos finais de "um canto telegráfico"379, que tanto mais trazem de inquietante a essa equação cujos termos não param de intercambiar posições - o que torna esse ideal do amor surrealista (como venho supondo), ilimitado e transitório. Talvez seja mesmo o trânsito ou a movência a única possibilidade de pronúncia sobre o amor, nos termos propostos por Cesariny. O amor, conforme há pouco, como motor ou combustível para essa grande razão (ou grande motivação): a de deslocar e promover no próprio sujeito um deslocamento tal que não se torna possível fixá-lo ou, por meio dele, fixar-se (para enfatizar a questão da subjetividade). Assim, inscreve-se: "Ama como a estrada

\footnotetext{
${ }^{376}$ Idem, p. 27.

${ }^{377}$ Idem, p. 80.

${ }^{378}$ Idem, p. 100.

${ }^{379}$ Trata-se de um belo poema de amor, cuja remissão à mensagem, inscrita em "telegráfico" (que por oposição, nada tem de conciso ou condensado), faz jus a ideia de lentidão - bastante frequente no poema - que marcaria o ritmo dos caminhos em direção ao encontro amoroso. As figurações do corpo são constantes também aqui.
} 
começa" ${ }^{380} \mathrm{e}$, em variante que muito diz a respeito dos trânsitos, deslocamentos e trajetos existenciais: "O que é o destino?/ É o amor a todo o comprimento."381. Em carta à Cruzeiro Seixas, o amor, como possibilidade de fusão mediante o gozo erótico, é a possibilidade de salvar-se do desinteresse diante do mundo: "E tu sabes que uma fusão total de dois seres só na posse normal se consegue e dura minutos, segundos. Ver-nos recusada essa graça faz olhar o mundo com um desinteresse intuitivo, desesperado, que atinge a imbecilidade., ${ }^{, 382}$

Em relação ao trânsito de significação a que estaria condicionada a ideia de amor, creio ser possível pensar a questão de identidade de gênero, em mais de uma composição de Cesariny. A começar por "o regresso de ulisses”:

O HOMEM É UMA MULHER QUE EM VEZ DE TER UMA CONA TEM UMA PIÇA, O QUE EM NADA PREJUDICA O NORMAL ANDAMENTO DAS COISAS E ACRESCENTA UM TIQUE DELICIOSO À DIVERSIDADE DA ESPÉCIE. MAS O HOMEM É UMA MULHER QUE NUNCA SE COMPORTOU COMO MULHER, E QUIS DIFERENCIAR-SE, FAZER CHIC, NÃO CONSEGUINDO COM ISSO SENÃO PRODUZIR MONSTRUOSIDADES COMO ESTA FAMOSA “CIVILIZAÇAO OCIDENTAL” SOB A QUAL SUFOCAMOS MAS QUE, FELIZMENTE, VAI DESAPARECER EM BREVE.

PELO CONTRÁRIO, A MULHER, QUE É UM HOMEM, SOUBE SEMPRE GUARDAR AS DISTÂNCIAS E NUNCA PRETENDEU SUBSTITUIR-SE À VIDA SISTEMATIZANDO PUERILIDADES, COMO FILOSOFIA, AVIAÇÃO, CIÊNCIA, MÚSICA (SINFÓNICA), GUERRAS, ETC... ALGUNS PEDANTES QUE SE TOMAM POR LIBERTADORES DIZEM-NA “ESCRAVA DO HOMEM” E ELA RI ÀS ESCÂNCARAS, COM SUA CONA, QUE É UM HOMEM.

DESDE O INÍCIO DOS TEMPOS, ANTES DA ROBOTSTÓNICA GREGA, OS ÚNICOS HOMENS-HOMENS QUE APARECERAM FORAM OS HOMENSMEDICINA, OS HOMENS XAMÃS (HOMOSSEXUAIS ARQUIMULHERES). ESSES E AS AMAZONAS (SUPER-MULHERES-HOMENS). MAS UNS E

\footnotetext{
${ }^{380}$ CESARINY, Mário. Uma grande razão: os poemas maiores. Lisboa: Assírio \& Alvim, 2007, p. 107.

${ }^{381}$ CESARINY, Mário. Primavera autónoma das estradas. Lisboa: Assírio \& Alvim, 1980, p. 103.

${ }^{382}$ CESARINY, Mário. Cartas de Mário Cesariny para Cruzeiro Seixas. (Org.: Perfecto E. Cuadrado, António Gonçalves, Cristina Guerra). Lisboa: Assírio \& Alvim (Documenta), 2014, p. 40.
} 
OUTRAS ERAM DEMAIS DEMAIS. E DESDE O INÍCIO DOS TEMPOS QUE PENÉLOPE ESPERA O REGRESSO DE ULISSES. MAS O REGRESSO DE ULISSES É O HOMEM QUE É UMA MULHER E A MULHER QUE É UMA MULHER QUE É UM HOMEM. ${ }^{383}$

Ora, não há dúvidas de que a característica mais evidente do texto é a (con)fusão da divisão binária dos gêneros - muito embora essa divisão seja o ponto de partida, uma vez que homem e mulher são vocábulos definidores de categorias, de acordo com o estabelecimento dos papéis tradicionalmente fixados, conforme lemos nos trechos: "[o homem] QUIS DIFERENCIAR-SE, FAZER CHIC, NÃO CONSEGUINDO COM ISSO SENÃO PRODUZIR MONSTRUOSIDADES COMO ESTA FAMOSA “CIVILIZAÇAO OCIDENTAL” e "[a mulher] SOUBE SEMPRE GUARDAR AS DISTÂNCIAS E NUNCA PRETENDEU SUBSTITUIR-SE À VIDA SISTEMATIZANDO PUERILIDADES, COMO FILOSOFIA, AVIAÇÃO, CIÊNCIA, MÚSICA (SINFÓNICA), GUERRAS, ETC..."; em que o papel histórico e social do homem e da mulher é retratado. De certo, esse retrato não cede a uma proposta de neutralidade, uma vez que o posicionamento inscrito é evidente: enquanto o homem seria responsável pelas monstruosidades - que, bastante de acordo com as diretrizes surrealistas, aparecem como sinônimo da sociedade ocidental - a mulher teria sido suficientemente esclarecida para não se envolver em tal construção civilizacional. $O$ posicionamento é de tal modo radical, que "guerras" torna-se termo equivalente em prejuízo aos termos que metonimicamente representariam a sociedade ocidental, como "filosofia", "aviação", "ciência" e "música sinfónica": há, desde logo, uma operação subversiva, uma vez que a acusação de produzir monstruosidades incide inclusive nos valores culturais usualmente acolhidos positivamente.

A respeito da subversão operada diante do binarismo ocidental homem/mulher, creio ser possível uma aproximação com os seguintes dizeres de Annie Fausto Sterling, em que notamos constatação parecida com a de Cesariny: "Os modos euro-americanos de entender o funcionamento do mundo, que dependem, em grande parte, do uso de dualismos - pares de conceitos opostos, objetos ou sistemas de crenças (...)”, para concluir, a parti daí que "Nós geralmente fazemos uso dos dualismos como forma de

${ }^{383}$ CESARYNI. Mário. Pena Capital. Lisboa: Assírio \& Alvim, 2004, pp.206, 207. 
hierarquização dos argumentos. " ${ }^{384}$. Ora, hierarquizar não significa senão estabelecer valores que adquirem aceitação social, bem como "desvalores" que são, por conseguinte, estigmatizados socialmente. Conforme a estudiosa, tais valores são balizados por pares de opostos. Nesse mesmo sentido, vale trazer a reflexão de Judith Butler, que se questiona a respeito de "como e por que a 'materialidade' se tornou sinal de irredutibilidade; em outras palavras, como é que a materialidade do sexo é entendida como algo que apenas sustem as construções culturais e, entretanto, não pode ser ela mesma uma construção.” ${ }^{\text {„85 }}$. Na mesma esteira de raciocínio, se pronuncia Anne Fausto Sterling:

Falar em materialidade é falar sobre os processos de materialização. E se os pontos de vista acerca do sexo e da sexualidade já estão embutidos nos nossos conceitos filosóficos a partir da maneira como a matéria se transforma em corpos, a matéria dos corpos não pode formar um solo neutro e preexistente daquilo que nós entendemos como a origem das diferenças sexuais. ${ }^{386}$

Creio ser justamente este o cerne da discussão de Cesariny, dado que o seu texto comporta, além de uma consciência das representações tradicionais do gênero (com as quais, inclusive, dialoga, no sentido de se colocar como um provocador por meio de uma operação de subversão valorativa), também uma dissolução do binarismo instaurado. As representações tradicionais saltam à vista logo no título do texto: "o regresso de ulisses". Ora, ao buscar referencia cultural tão longínqua em que a representação do homem e da mulher são já definidas pelos estereótipos de gênero que condicionam ainda hoje nossa percepção, Cesariny nada mais faz do que mostrar que a "sociedade ocidental" - ancorada na mundividência Grega - necessita ser revista, e a

\footnotetext{
${ }^{384}$ Tradução minha a partir do original: "Euro-American ways of understanding how the world works depend heavily on the use of dualisms - pairs of opposing concepts, objects, or belief systems. (...). We use employ dualisms in some form of hierarchical argument." (FAUSTO-STERLING, Anne. Sexing the body. New York: Basic Books, 2000, p.21).

${ }^{385}$ Tradução minha a partir do original: “(...) to ask how and why 'materiality' has became a sign of irreducibility, that is, how is it that the materiality of sex is understood as that which only bears cultural constructions and, therefore, cannot be a construction" (BUTLER, Judith. Bodies that matter: On the discursive limits of sex. New York: Routledge, 1993, p. 28).

${ }^{386}$ Tradução minha a partir do original: "To be material is to speak about the process of materialization. And if viewpoints about sex and sexuality are already embedded in our philosophical concepts of how matter forms into bodies, the matter of bodies cannot form a neutral, pre-existing ground from which to understand the origins of sexual difference." (FAUSTO-STERLING, Anne. Sexing the body. New York: Basic Books, 2000, p. 22).
} 
revisão é mesmo a ideia aqui patente de rompimento com o binarismo imposto, claramente elucidado nas palavras do próprio Cesariny: "E DESDE O INÍCIO DOS TEMPOS QUE PENÉLOPE ESPERA O REGRESSO DE ULISSES. MAS O REGRESSO DE ULISSES É O HOMEM QUE É UMA MULHER E A MULHER QUE É UMA MULHER QUE É UM HOMEM.”. Creio, entretanto, ser possível afirmar, a partir deste trecho, maior complexidade no recado que nele estaria inscrito: o regresso de Ulisses, se entendido como ação que possibilitaria a dissolução da lógica binária (uma vez que “O REGRESSO DE ULISSES É O HOMEM QUE É UMA MULHER E A MULHER QUE É UMA MULHER QUE É UM HOMEM.”), é algo que se aproxima do próprio ideal surrealista. Penélope, a tecelã, seria portanto, uma figuração do próprio Cesariny enquanto aquela/ele que espera, nos meandros entre tecer e desfiar o seu texto através dos tempos. Pois é mesmo esse o empenho de Cesariny: simultaneidade entre o ir e o vir na urdidura surrealista.

Curioso é notar que a palavra amor não é mencionada ao longo do texto. Disso, não creio ser possível concluir a ausência do amor como modo de mutação perceptiva, muito ao contrário: tendo em vista o surrealismo como mote existencial cujo pilar de maior sustentação é justamente o amor, acredito haver autorização para que toda proposta subversiva apresentada pelos surrealistas seja considerada sob o prisma do amor. Tanto mais, se considerarmos que na visão tradicional da divisão dos gêneros, a mulher é aquela a quem o amor é permitido: enquanto o homem deveria ocupar-se em manter-se fiel aos princípios da razão para que a "roda" civilizacional continuasse a girar; a mulher, diferentemente, aquela que dá a vida - e por isso deve estar habilitada para abrigar a prole -, serve-se desde sempre da afetuosidade e do amor como agentes caracterizadores da sua condição geradora. Tal interpretação se confirma, caso considere-se que, neste texto, a mulher é apresentada como dotada de uma espécie de superioridade em relação ao homem, já que, de acordo com Cesariny, ela não seria responsável pelos feitos que caracterizariam as "monstruosidades" da "civilização ocidental". A afetuosidade amorosa, portanto, como modo superior de atuação.

Ainda o aspecto gráfico da composição merece ser referido: a caixa alta que a caracteriza do princípio ao fim conota grande ênfase ao texto, de tal modo que, se me imagino diante de uma leitura ou performance, a representação da voz que mais fielmente se adequaria ao aspecto gráfico, seria o grito ou o uso de um alto-falante, como se nele estivesse marcada a pretensão de um grande alcance, ou a subscrição: ninguém deve sair imune deste rompimento radical com o indivisível dos gêneros, ou, 
em termos mais propriamente fenomenológicos, todos são quem são devido ao contato de si com o outro (nesse caso, apresentados mediante metonímia das partes do corpo distintivas: cona e piça), ou ainda: a subjetividade e a intersubjetividade são faces de uma mesma existência, noções interdependentes e interdeterminantes, exatamente conforme nos seguintes versos de "corpo visível": "porque nós somos a multidão a que eu chamo/ o homem e a mulher de todos os tempos áridos.",387

Importa referir outro texto/montagem/versão em que o princípio de intersubjetividade, muito originalmente posto, aparece (dentre outros deslocamentos) na intersecção idiomática:

"inscrições inscriptions"

I am eu southe first a primeira and the last Conception e a última concepção.

The Lady of Lourdes. A senhora de Lourdes.

I am eu sou the first a primeira and the last e a última

I am eu sou the honored one a venerada and the scarned one e a execrada

I am eu sou the whore a puta and the holy one a santa

I am eu sou the wife a mulher and the virgin e a menina

I am eu sou the mother a mãe and the daughter e a filha

I am eu sou the members o clã of my mother de minha mãe

Eu sou I am the barren one a estéril

and many e muitos are her sons são seus filhos

I am eu sou she whose wedding aquela cuja boda is great é grande

and I have not taken e não aceitou a husband marido

I am eu sou the bride a noiva and the bridegroom e o noivo

and it is my husband e meu marido who begot me é quem me gerou

I am eu sou the mother a mãe of my father de meu pai

and the sister e a irmã of my husband de meu marido

and he is e ele é my offspring a minha descendência.

Ishtar, Suméria. ${ }^{388}$

\footnotetext{
${ }^{387}$ CESARINY, Mário. Pena Capital. Lisboa: Assírio \& Alvim, 2004, p. 66.

${ }^{388}$ Idem, p. 221. A respeito do texto transcrito, não pude encontrar referências de sua origem, mas tudo indica tratar-se de uma montagem composta a partir de inscrições sumérias e o dito de Nossa Senhora de Lourdes, que em 1858, é indagada por Bernardette Soubirous, ao que responde: "Eu sou a Imaculada
} 
Ao retomar a inscrição suméria (nota-se a não-ocidentalidade da escolha textual: como se falar a partir de uma civilização que situou-se no Oriente Médio, fosse per si desestabilizar a tradição ocidental), Cesariny parece obedecer ao mesmo princípio de diluição do binarismo apontado em "o regresso de ulisses", com o acréscimo, a ser amplamente considerado, de ser esta uma sua apropriação - marcada, evidentemente, pelo uso do idioma português, que neste caso funciona como traço identitário do poeta. Tal modo de apropriação, considera que o texto em português não precede nem sucede o texto em inglês, mas o atravessa. Tal atravessamento ocorre como se não houvesse fronteira de delimitação, a mesma fronteira que parece estar ausente nos modos como a Senhora de Lourdes se define amplamente pelos opostos que caracterizam a condição da mulher: a primeira e a última, a venerada e a execrada, a puta e a santa, a mãe e a estéril, etc. $\mathrm{O}$ atravessamento do texto ocorre também em relação às tradições originais: se o texto, (supõe-se pela indicação de Cesariny) tem origem suméria, Nossa Senhora de Lourdes, por outro lado, é referência direta ao mundo cristão. Os atravessamentos, portanto, são de ordens diversas e rompem, eu arrisco dizer, com binarismos em múltiplas instâncias, rompimento que vai desde a questão idiomática, passando pela divisão do mundo em Ocidente e Oriente, pelos tempos históricos, até chegar ao que parece ser a questão central da composição referida: o ideal de feminilidade. Ao fim do texto, os atravessamentos rompem, inclusive, com a noção de causalidade inscrita nos vínculos familiares, de modo que há subversão também nos modos de perceber as relações parentais, fato que aponta para um desmonte do padrão relacional marcado pelos elos consanguíneos e, mais além, supõe um princípio de totalidade inclusivo. Conforme bem elaborado por Alberto Pimenta:

Rapp conclui que o homem é antes de mais persona, isto é, sujeito capaz de fazer um papel e existir dentro dele sem com ele se identificar: a unidade do sujeito é "um conglomerado aberto de papéis representados, fantasiados e representáveis por citação (cit, 168). Mas antes de qualquer fundamentação psico-social está o fingimento próprio do verbo "ser" e seus caprichos predicativos. Que é que se é, e que é ser-se alguma coisa? Passa-se de 'filho' a 'pai' sem deixar de ser 'filho', mas de algum modo deixando de o ser, ao

Conceição". Em Pena Capital, o texto situa-se numa seção intitulada "CORTINA", em que há uma diversidade de poemas que evocam tradições variadas (ex.: "carta do xamã”, "um poema transmitido por frank mitchel"), de poemas escritos em outros idiomas (carta casi-poema para octavio paz", "meditación de Leonor de aquitánia ante un cuadro de enrique carlón", "mário sério", "exquisite poem”) de modo que tais evocações se compõem, com frequência, de colagens textuais, o que sugere, de fato, uma apropriação por parte de Cesariny, de uma multiplicidade imensa de "outros" e "exteriores": há mesmo um deslocar-se (inter)subjetivo continuado. 
delegar essa qualidade num novo vértice de triângulo. Algo passou (para fora), algo do que se 'é'. Esse fluir de dentro para fora e de fora para dentro (relativo de acordo com a perspectiva, claro) não permite que a predicação se estabilize senão num conceito ou numa imagem. Este conhecimento leva por sua vez ao reconhecimento de que o homem nunca 'é' verdadeiramente, ou seja, nunca coincide com a sua imagem ou com o seu conceito. A lógica supera isso com a "adequação", desligando-se da experiência; a poesia aproveita a experiência disso para por em dúvida os conceitos, e realçar a constante mudança do que 'é' no que 'não é'. ${ }^{389}$

Pertinente, ainda, nesse caso, pensar com Eliane Robert Moraes:

Entende-se porque a justaposição de duas realidades distintas
permanecia, para Breton, como a tarefa mais elevada que a poesia
poderia pretender. Aos olhos dos surrealistas, a frase de Lautréamont
representava a mais perfeita realização dessa tarefa, na medida em
que o encontro entre a máquina de costura e o guarda-chuva vinha
confirmar seus anseios de uma poesia na qual 'as palavras fizessem
amor'. ${ }^{390}$

Sobre a imagem da mulher tal qual aqui se apresenta, creio que pode ser pensada em relação àquela que vimos em Herberto Helder: tanto Cesariny quando Helder parecem supor a mulher, conforme a sua condição de geradora, como aquela que seria capaz de criar, mediante princípios não inscritos na tradição racionalista, uma outra maneira de estabelecimento relacional. No caso de Cesariny, no entanto, o homem também irá figurar com certa centralidade de atuação diante destes "possíveis" (no sentido de atentar para os modos possíveis de configuração social/ inter-relacional) aos quais o surrealismo presta homenagem. O homem, no caso de Cesariny, assume, talvez, um papel parecido com o da mulher em Herberto Helder, no sentido de ser protagonista do amor na atividade erótica. Em Cesariny, o poder subversivo do amor e do erotismo aparece como figuração do homoerotismo, também ela, como possibilidade de rompimento no que se refere aos padrões relacionais instituídos.

Neste trecho de composição intitulada "Segismundo", flagramos a centralidade do homem e, embora ainda não apareça o caráter homoerótico, já é possível considerar a percepção fisiológica como uma das marcas determinantes da composição subjetiva:

\footnotetext{
${ }^{389}$ PIMENTA, Alberto. A magia que tira os pecados do mundo. Lisboa: Cotovia, 1995, pp. 98, 99.

${ }^{390}$ MORAES, Eliane Robert. O corpo impossível. São Paulo: Iluminuras: 2005, p. 49.
} 
O esperma é o substanto primordial. Fusos de esperma, litros de substanto. Sobre eles trabalharemos. Dos seus fios inócuos, insignificantes, tiraremos os semas, os sinais-intervalos, as retenções qualitativas texturais. Quando não houver mais nada para tirar ainda os sentaremos na cadeira elétrica, finalmente ligados ao colimador.

Este o final da aula de Segismundo. Todos os estudantes dispersaram, em direção à encosta das flores. À noite o esperma levantou-se e bateu-lhe. Estava verdadeiramente irado. Encostas-te demais!, gritava. A cara de Segismundo começou a ficar cheia de esperma. E sua cabeça, pelo túnel da nuca, tomava o comboio para a viagem do sim, do não e do nunca. ${ }^{391}$

De modo semelhante, lemos em Apresentação do Rosto de Herberto Helder:

Já não sabia o que fazer, pois encontrava esperma entre as páginas dos livros, nos bolsos, nos cigarros. Uma vez atirou fora os cigarros e gritou: porque está aqui, esperma, nos cigarros? Nem se pode fumar. $E$ depois como foi? Parece que o esperma invadia tudo. ${ }^{392}$

Ora, em ambos os casos, há esse ponto de partida condicionante: a materialidade (em termos fisiológicos) de que a situação masculina é a expressão. No caso de Herberto Helder, no entanto, essa percepção induzida pelo constructo da materialidade (conforme reflexão há pouco evocada por Annie Fausto-Sterling e Judith Butler, uma vez que suponho, com as autoras referidas, que também a nossa percepção das diferentes configurações da matéria é uma construção e, portanto, pode ser alterada), nos parece ser mais determinante - no sentido de limitação das possibilidades - do que no caso de Cesariny. E digo isso tendo em vista a leitura que apresentei há pouco das diferenças manifestas entre homem e mulher na criação herbertiana. No caso de $\mathrm{HH}$, há um lugar bem definido para a subjetividade masculina e outro lugar (o lugar da alteridade) para a subjetividade feminina. Ambos se encontram, claro esteja, e este encontro se dá sobretudo pelas possibilidades eróticas. Em Cesariny, diferentemente, essas condicionantes me parecem mais facilmente “diluíveis". Explico: parece haver um empenho maior em intercambiar essas percepções que, de algum modo, condicionariam nossa maneira de definir homem e mulher como categorias não coincidentes. Se, por um lado, Cesainy está atento às figurações tradicionais que fazem do homem e da mulher duas instituições diversas, por assim dizer (e essa atenção de Cesariny se manifesta nos juízos que faz dos

\footnotetext{
${ }^{391}$ CESARINY, Mário. Primavera autónoma das estradas. Lisboa: Assírio \& Alvim, 1980, p. 202.

${ }^{392}$ HELDER, Herberto. Apresentação do Rosto. Lisboa: Ulisseia, 1968, p. 111.
} 
gêneros tradicionalmente fixados) por outro lado, seu esforço é na direção de desestabilizar esses lugares tradicionais. A exemplo do trecho de "Segismundo", lemos que o personagem, completamente tomado pelo esperma primordial passa por um processo que pode ser entendido como de dissolução das antinomias: "sua cabeça, pelo túnel da nuca, tomava o comboio para a viagem do sim, do não e do nunca", uma vez que o sim o não e o nunca mantém entre si, não relações de alternância, mas de acréscimo e simultaneidade, isto é, não há isto ou aquilo, mas isto e aquilo, exatamente como no "retorno de ulisses". Importa atentar, ainda, para o caráter metalinguístico do excerto: "Dos seus fios inócuos [fusos de esperma, litros de substanto], insignificantes, tiraremos os semas, os sinais-intervalos, as retenções qualitativas texturais.", o que equivale dizer que é a partir desta matéria primordial que a escrita/texto se faz.

Acerca da homossexualidade, Cesariny nos apresenta este jogo de palavras que muito elucida a respeito do caráter erótico-afetivo de uma dessas vias de que lança mão para dissolver antinomias:

"a homosexoalma"

A

ALMA

SEXO

$\mathrm{DO}$

HOMEM $^{393}$

As seguintes palavras de Octavio Paz são oportunas no sentido de evidenciar a importância do corpo, também no que diz respeito a uma ideia de alma (ainda que um tanto vaga e imprecisa) que, a meu ver, expressaria a esfera da sentimentalidade implicada na relação amorosa:

Para o amante o corpo desejado é alma; por isso lhe fala com uma linguagem para além da linguagem, mas que é perfeitamente compreensível, não com a razão, mas sim com o corpo, com a pele. Por sua vez, a alma é palpável: podemos tocá-la e seu sopro refresca nossas pálpebras ou aquece nossa nuca. Todos os apaixonados sentem essa transposição do corporal ao espiritual e vice-versa (...)

\footnotetext{
${ }^{393}$ CESARINY, Mário. Manual de prestidigitação. Lisboa: Assírio \& Alvim, 2008, p. 115. Em variação gráfica: "A ALMA SEXO DO HOMEM" (CESARINY, Mário. Burlescas, teóricas e sentimentais. Lisboa: Editorial Presença, 1972, p. 98.
} 
O amante ama o corpo como se fosse alma e a alma como se fosse corpo. ${ }^{394}$

As referências à homossexualidade são múltiplas em Cesariny ${ }^{395}$, conforme é possível conferir nas seguintes passagens: "Gilgamesh/ (para quem não sabe: o primeiro herói lendário/ que também era bicha ou o primeiro bicha/ que também era herói, para quem saiba)"396 (no poema “ode a outros e a maria helena vieira da silva"); "Breve foi a amizade de Verlaine o bêbado/ E de Rimbaud o vadio, e em constante querela./ Mas podemos pensar que acaso um bom momento/ Houve para os dois, pelo menos ao recordarem/ Como tinham deixado para trás mãe insuportável e esposa enfadonha." ${ }^{397}$ ( versos de "um poema de luis cernuda birds in the night"). Ainda em carta para Cruzeiro Seixas, Cesairny afirma: “Ai! em todas as putas há uma verdade que eu amo (refiro-me a homens). ${ }^{398}$

De um modo ainda mais bem humorado e que muito vem a acrescentar sobre a discussão homoerótica, estes trechos do poema intitulado "Alheio...”: “(...)

E no Epithalamium fiz

Que pudessem saber

Que feliz ou infeliz

O sou como mulher

As costas do meu ser

Deixei em inglês

\footnotetext{
${ }^{394}$ PAZ, Octavio. A dupla chama: amor e erotismo. São Paulo: Siciliano, 1994, p. 116.

${ }^{395}$ A isso está atento também Manuel Gusmão, que vincula o interesse que Cesariny devotou à Artaud, dada à pulsão erótica e corporal: “(...) a repetida convocação de Artaud que, diga-se de passagem, é na constelação de referências electivas um nome mais intenso do que o de Breton (Artaud e Rimbaud são os nomes de poetas que mais magnetizam esta poesia) - marca-se em Cesariny, por uma maior visibilidade do corpo erótico, uma mais forte sexualização do Eros e uma mais nítida indignação com a desfiguração humana implicada pela repressão da pulsão homo-erótica (...)" (GUSMÃO, Manuel. "Entre nós e as palavras (Mário Cesariny)" In: Tatuagem e palimpsesto. Lisboa: Assírio \& Alvim, 2010.pp. 393, 394).

${ }^{396}$ CESARINY, Mário. Uma grande razão: os poemas maiores. Lisboa: Assírio \& Alvim, 2007, p. 129.

${ }^{397}$ CESARINY, Mário. Pena Capital. Lisboa: Assírio \& Alvim, 2004, p. 199.

${ }^{398}$ CESARINY, Mário. Cartas de Mário Cesariny para Cruzeiro Seixas. (Org.: Perfecto E. Cuadrado, António Gonçalves, Cristina Guerra). Lisboa: Assírio \& Alvim (Documenta), 2014, p. 199.
} 
Porque isso em português

Não o podia escrever

$(\ldots)$

E para homossexual

Não sou o António Botto

Nem o Raúl Leal.

O Botto para mim é pouco

E o Raúl é demais.

(...),399

A paródia feita a partir de uma suposta homossexualidade do Pessoa ganha dimensão intersubjetiva, se tivermos em mente que o título do poema, "Alheio...", aponta não apenas para o outro Pessoano (um outro homossexual, conforme referencia explícita e, mais além, reforçada pela menção aos nomes de António Botto e Raúl Leal - poetas homossexuais), mas ainda para os supostos trânsitos subjetivos, tão próprios ao modo de desdobramento que o Pessoa levou a cabo mediante a sua heteronímia. No caso deste poema, é como se o Cesariny se manifestasse liricamente como um heterónimo homossexual de Pessoa, sugestão que faço, uma vez que o poema é escrito em primeira pessoa, por Cesariny, em nome de um F. Pessoa homossexual.

Adiante, transcrevo na íntegra um poema em tom mais lírico sobre o mesmo tema homossexual, em que as intersecções subjetivas passam, evidentemente, pelo corpo próprio e pelo corpo outro:

Nunca estive tão só diz o meu corpo e eu rio-me

lembra-me alguém que se atardava sempre

diante de uma montra da rua da palma

a olhar para uma camisa que seria sua

assim que o ordenado lho pedisse

porque era aberta branca lisa de praia!

Seis e meia sete horas

saltava de vedeta vinda do Alfeite

e era como um gato

${ }^{399}$ CESARINY, Mário. O Virgem Negra. Lisboa: Assírio \& Alvim, 1989 (1ª Ed.), pp. 19-20. 
ia com os pés para a frente daquela montra só para ver só para olhar sem ser reparado só enquanto não fecham estas lojas Esse, ou o António, que gostava de homens E não só isso como o declarava dois e dois quatro a quem bem queria ouvi-lo porque, dizia, ajustando o corpete, homem sou eu dentro da minha farda

Nunca estive tão só diz o meu corpo e eu rio-me porque o corpo é o corpo não tem nada a fazer não tem para onde ir não lembra não se lembra quer estar sempre agarrado suprimido apertado e se é belo é pior vive num amarrote permanente

Sim decerto matéria atrai matéria a boca faz-se sangue o sangue faz-se esperma a urina espera a custo que o esperma se faça para vir de novo à superfície do ar Quando o total atinge a sua forma ejectável preme-se noutro corpo noutros lábios idênticos mas do lado de lá como num espelho sua fiel imagem convertida

Isso o meu corpo quer - o corpo - noite e dia ele julga que eu tenho a idade dele que ainda só sei do homem pelo que transporta a meia nau sobre o alto das pernas - o quadrado das ânsias respirando abertas - a diagonal dos braços formando-se em centro mas o meu centro de aeração mudou-se 
o meu relógio de mar parou em cima da mesa

o espelho meu foi puxado para trás

e foca - admirado - a magnificência liberta. ${ }^{400}$

Creio haver neste poema uma maior complexidade no que se refere à relação intersubjetiva, já que há uma espécie de personificação do corpo (aqui, manifesto como dotado de vontade própria, possivelmente uma metonímia do desejo erótico). "Sim decerto matéria atrai matéria/ a boca faz-se sangue o sangue faz-se esperma", constata o sujeito que detém a voz no poema, como se a supor a união ou mesmo a fusão que seria a tendência dos corpos eróticos, embora tal suposição seja resultado de um afastamento analítico. Do afastamento, passa-se a uma aproximação intensa: "Quando o total atinge a sua forma ejectável/ preme-se noutro corpo noutros lábios idênticos/ mas do lado de lá como num espelho/ sua fiel imagem convertida" o corpo próprio, já como manifestação subjetiva, encontra o corpo outro ("preme-se noutro corpo noutros lábios idênticos") e esse encontro é como ver-se num espelho: ora, há aqui a sugestão da homossexualidade (já evocada em versos anteriores: "Esse, ou o António, que gostava de homens/ E não só isso como o declarava dois e dois/ quatro a quem bem queria ouvi-lo/ porque, dizia, ajustando o corpete,/ homem sou eu dentro da minha farda"), pela ideia de que o espelho reflete o que se coloca diante dele: um corpo de homem; mas há também a ideia de que o encontro erótico proporciona identificação entre as subjetividades envolvidas. Na última estrofe, há novamente afastamento pela distinção entre sujeito (eu) e corpo (ele), o que gera, por consequência, um afastamento entre amado e amante, conforme se lê: "o meu relógio de mar parou em cima da mesa/ o espelho meu foi puxado para trás. e foca - admirado - a magnificência liberta.". Supondo-se que o espelho represente o amante (o outro tornado eu mediante o encontro amoroso), conforme venho fazendo, nota-se que, estando distante, pode apenas focar a "magnificência liberta". Curioso é pensar que a identificação entre eu e outro induzida pela imagem do espelho é considerada na contramão da liberdade, uma vez que a atração da matéria pela matéria (ato erótico de fusão intersubjetiva, tal qual a leitura que proponho do poema), não permitiria a liberdade decorrente do afastamento do espelho. Essa espécie de espiral que se move em duplo sentido (a saber: 1) corpo $\neq$ do enunciador/amador $\neq$ do amante, e 2) corpo $=$ enunciador/amador $=$ amante), além

${ }^{400}$ CESARINY, Mário. Uma grande razão: os poemas maiores. Lisboa: Assírio \& Alvim, 2007, p. 133. 
de atestar os trânsitos e deslocamentos subjetivos, conforme visto nos demais textos trazidos para análise, dá um salto na direção de supor liberdade aquilo que estaria para além das possibilidades do corpo (no sentido de que ultrapassaria os desejos do corpo) e, na linha de leitura na qual venho insistindo, em que a subjetividade deve ser pensada como eixo do corpo perceptivo, a liberdade seria, portanto, aquilo que está para além das possibilidades da própria existência. Outra maneira (imagino que menos taxativa) de conceber o ato de liberdade seria, portanto, uma não identificação absoluta de nada com nada: sem haver espelhos, o sujeito poderia circular ou deslocar-se indefinidamente de modo a não haver contornos que o limitassem. Num caso ou no outro, o que parece estar em questão, é um desejo de ultrapassar-se, ultrapassando as barreiras condicionantes da existência - como é o intuito maior do surrealismo. Tanto assim, que em $A$ cidade queimada - livro resultante de uma viagem à Paris e, ao que tudo indica, onde o poema em questão é publicado pela primeira vez - Cesariny explicita em forma de "diário de composição" os acasos que nortearam a elaboração do poema e que muito têm a dizer acerca de como o amor se estabelece diante da “situação do poeta em relação ao mundo". Segue o longo trecho, datado de 1 de Junho de 1964, a esse respeito:

À noite, esqueço os poemas e começo a ler Borges. Abro o livro ao acaso, no metropolitano. Detenho-me no ensaio "O espelho dos Enigmas". Um itálico chama-me a atenção: Videmus nunc per speculum in aenigmate: Tunc autem facie ad faciem. Num cognosco ex parte: Tunc autem cognoscom sicut et cognitus sum. E a tradução abaixo (a que prefiro, de Cipriano de Valera): "Agora, vemos num espelho, obscuramente; mas então veremos face a face. Agora conheço parcialmente; então, conhecerei tal como sou conhecido". Apesar do meu latim nenhum, posso fazer melhor:

Vemos como num espelho, por enigma é a segunda estrofe do meu poema! No seu intacto sentido:

\footnotetext{
premimos outro corpo outros lábios idênticos mas do lado de lá como num espelho sua fiel imagem convertida
}

e não só; na igual propriedade das palavras e na direção que tomam, na última parte do versículo como no final do meu poema que, depois de denunciar o encontro meramente casual, carnal, do corpo com os corpos, escolhe o conhecimento que é amor por ligação aos mais remotos rostos do universo. Para além da passagem ininteligente das coisas (agora, conheço parcialmente), os esponsais da lucidez e do desejo (então, conhecerei tal como sou conhecido): 
isso o meu corpo quer - o corpo - dia e noite

ele julga que tenho a idade dele

mas o meu centro de aeração mudou-se

o meu relógio de mar parou em cima da mesa

o espelho meu foi puxado para trás

e foca-admirado-a magnificência liberta

Parece-me inútil frisar, mas à cautela de friso, que estes versos e a narrativa do seu acontecimento não intercedem por qualquer humanização do divino ou crédito de vida como a sonham os católicos. Eles apenas continuam numa forma inesperada porque conclusiva de uma nova, nova para mim, situação do poeta em relação ao mundo - ao seu mundo amoroso - que lhe surge pela primeira vez não através, ou não só através, do corpo amado, como instrumento de gozo, de imaginação e de posse, mas tocando em seu todo o mundo das formas, a própria imaginação do universo. ${ }^{401}$

É mesmo de uma ultrapassagem que se trata: o trecho referido como sendo representante de parte do poema ${ }^{402}$ ("Vemos como num espelho, por enigma"), em que a semelhança dos trechos seria consequência de uma percepção dos limites que, ao fim do poema, se manifesta como uma nova "situação do poeta em relação ao mundo - ao seu mundo amoroso -", de modo que o corpo não se restringiria ao mero gozo, mas se deslocaria em direção "a própria imaginação do universo", o que também pode ser dito de outra maneira: o corpo como manifestação existencial a direcionar-se para os outros (muitos e plurais), "escolhe o conhecimento que é amor por ligação aos mais remotos rostos do universo", sem que tenha como fixada ou prévia qualquer noção identitária, exatamente conforme visto em poema do capítulo anterior "a antonin artaud". Ainda noutro trecho de carta a Cruzeiro Seixas, Cesariny diz, a esse respeito: “ (...) há quem não viva no mundo do Princípio de Identidade, chave geométrica de todo o pensamento dedutivo e de todo o cartesianismo, antigo ou moderno."403. O amor, portanto, como elo, ligação, o amor como conhecimento: a intersubjetividade como sinônimo da subjetividade.

${ }^{401}$ CESARINY, Mário. A Cidade Queimada. Lisboa: Assírio \& Alvim, 2000, p. 43-45.

${ }^{402}$ A segunda estrofe, em nenhuma das duas publicações referidas, equivale ao trecho apontado por Cesariny que, diferentemente, compõe parte da terceira estrofe. Possivelmente, trata-se de uma distração.

${ }^{403}$ CESARINY, Mário. Cartas de Mário Cesariny para Cruzeiro Seixas. (Org.: Perfecto E. Cuadrado, António Gonçalves, Cristina Guerra). Lisboa: Assírio \& Alvim (Documenta), 2014, p. 95. 


\subsection{Cruzeiro Seixas e o amor transfronteiriço}

Para tratar do modo como Cruzeiro Seixas se movimenta nos interstícios relacionais, vale trazer alguns de seus pronunciamentos a esse respeito, especialmente no que tange ao amor:

O Poeta

tem para dizer

A M O R

O poeta

não é um sonhador...

\section{África $58^{404}$}

Ora, estas duas pequenas estrofes, que leio como manifestação de uma definição poética, encontram eco em toda a sua produção. Deslocar o dizer primordial do poeta do sonho para uma suposta realidade (ainda que não pronunciada), é manifestar o amor como forma de existência, especialmente, se tivermos em vista a poesia como manifestação existencial, percurso que venho trilhando ao longo da pesquisa. Cruzeiro Seixas reitera essa visada, por exemplo, nos versos iniciais de um poema de África datado de 65: "Quando eu morrer/ ponham-me à janela como uma prostituta/ a escrever poemas sobre poemas/ até atingir a altura do Empire State Building." ${ }^{405}$. Ora, há aqui, não apenas a manifestação de uma infinitude - expressa no fato de que a morte não seria um impeditivo à existência poética -, (infnitude, aliás, que perpassa seus escritos, conforme é possível conferir nos seguintes dizeres: “A minha convivência com os corpos foi feita intensamente no amor, mas um corpo para mim nunca foi somente um corpo, mas um lugar de conjunção de todos os infinitos. ${ }^{406}$ ), mas sobretudo o desejo de um amor - figurativizado na imagem da prostituta, aquela que exercita o amor expansivo - que seja capaz de aumentar em verticalidade, mediante o ofício poético. Amor e poesia aliados na existência, sendo o corpo, como bem formulou Jean-Luc Nancy (e em confluência com a fenomenologia

\footnotetext{
${ }^{404}$ SEIXAS, Cruzeiro. Obra poética (vol. II). Vila Nova de Famalicão: Quasi Edições, 2003, p. 346.

${ }^{405}$ SEIXAS, Cruzeiro. Obra poética (vol. I). Vila Nova de Famalicão: Quasi Edições, 2002, p. 45.

${ }^{406}$ MARTINS, Floriano, SEIXAS, Cruzeiro. "FLORIANO MARTINS | Cruzeiro Seixas - O horizonte sob desmedida" In: Agulha Revista de Cultura, sábado, 19 de setembro de 2015 http://arcagulharevistadecultura.blogspot.com.br/2015/09/floriano-martins-cruzeiro-seixas-o.html.
} 
de M. Ponty) o lugar mesmo dessa existência.

E diz ainda: "Ouvir dizer ao ouvido AMO-TE é ainda muito mais emocionante (é preciso confessá-lo) que ouvir gritar lá fora a palavra LIBERDADE..."407, possibilitando, com isso, deslocar o eixo do que deve ser percebido como liberdade na situação amorosa, conforme a reflexão de Octavio Paz: "Os poetas também poderiam ter dito que o amor nasce de uma atração involuntária que nosso livre-arbítrio transforma numa ação voluntária. Este último é sua condição necessária, o ato que transforma a servidão em liberdade." ${ }^{408}$.

Como proposta que perseguimos insistentemente, importa considerar a evidente metalinguagem que lança o fato amoroso para o território poético. Em acréscimo às reflexões desenvolvidas até então, trata-se de considerar o poema como ato amoroso por excelência, como matéria resultante daquilo que o amor entre os seres é capaz de gerar. A começar por este poema escrito todo a partir da preterição (que se inicia, justamente, com a ideia de infinitude que há pouco ressaltei):

Neste poema sem fim

não canto o silêncio dos lírios

nem a pequena roda dentada

dentro do sol.

Não o estar contigo no deserto

unos

ao descer a fachada do nada.

Não a música dos instrumentos silêncios

dentro da tua mão

nem a pontualidade dos gritos

sob as pedras.

Não os barcos todos

navegando os teus sonhos

nem os cabelos amordaçados pelo vento.

Nem o corredor das portas agudas

\footnotetext{
${ }^{407}$ Idem, ibidem.

${ }^{408}$ PAZ, Octavio. A dupla chama: amor e erotismo. São Paulo: Siciliano, 1994, p. 68.
} 
nem o trintanário de mitra e báculo.

Não as palavras usadas

mas uma flor

como uma faca.

Não o local para sermos erva

não o local para sermos azul

não o local para sermos as chamas vegetais

rompendo o mar

não as garras afagando o manto de ferro

não as figuras habitadas

de intermináveis tempestades

não as árvores emigrantes

não o leque de estrelas

ou a taça de cristal

adorada como um ídolo num país distante

e não a mancha em forma de pássaro

na parede do meu quarto.

Não ainda a gargalhada do peixe

não as palavras proféticas

do cão de guarda

não os monstros arrastando

mãos desirmanadas

não a lente para aumentar o nada

não a espuma como promessa do amanhã

não o teu corpo cravejado de ponteiros translúcidos

mapa de outra guerra.

Não o mar cruzado por comboios

não o mar sentado à nossa mesa

não o mar dentro das nossas cartas

não o mar com janelas abertas

sobre paisagens fechadas.

Não as viagens de todos os dias

não o cego e o seu violino

não o perfil desenhado no chão do caminho 
infinito

não o papel cenário para as viagens de Gulliver

não o ruído motor do leito

não o amor sob a ponte dos polícias

não o vitral iluminando a morte

de que se fala tanto.

Não a morte

de que nunca poderemos falar

não a luz desfalecendo na esquina

entre dois avestruzes vermelhos

e uma salva de 21 tiros.

Não o ruído exangue

nem as pulgas de longas barbas brancas

não a inspiração poética bebendo o mesmo amargo café

não as luzes apenas iluminando a cena

e esquecendo os risos.

Não o marítimo caminhando para o fundo do mar

não a calçada quando chove

molhada

não o eco

não as lágrimas

nem as quatro patas dos teus olhos

riscando vidros.

Não os náufragos descendo à cidade

não a terra natal dos enforcados

não o estrangeiro crucificado

não a tua ausência

oh meu amor

fielmente

sempre sempre ao meu lado

África $57^{409}$

${ }^{409}$ SEIXAS, Cruzeiro. Obra poética (vol. II). Vila Nova de Famalicão: Quasi Edições, 2003, p. 238-240 
O uso da preterição, figura retórica que realiza, no discurso, aquilo que afirma não realizar (no caso do poema de Cruzeiro Seixas, o próprio canto poético, daí a metalinguagem ${ }^{410}$ que se desdobra nos seguintes trechos: "Neste Poema sem fim/ não canto(...)", "Não as palavras usadas", "não as palavras proféticas", "não a inspiração poética bebendo o mesmo amargo café"), cumpre a função de embaçar por completo os limites entre o que é e o que não é. Conforme bem definiu Alberto Pimenta acerca do sobrenatural inscrito em Aleister Crowley: "Quem pretende realizar a Grande Obra, no sentido alquímico, diz Aleister Crowley, aspira ao casamento de tudo o que ele é com tudo o que ele não-é, para verificar depois que tudo o que ele é e tudo o que ele não-é são idênticos." ${ }^{411}$. Claro esteja, que a mística presente no discurso do bruxo com quem F. Pessoa esteve às voltas, no caso de Cruzeiro Seixas, se converte num imaginário de natureza abrangente (e por meio desta expressão, me refiro aos modos pelos quais às imagens da natureza são combinadas a qualificativos abstratos ou difusos, responsáveis por tornar flutuante uma visão que correria o risco de encerrar-se na mera objetividade), especialmente notável em momentos como os tais: "Não o estar contigo no deserto/ unos/ ao descer a fachada do nada.", "não a lente para aumentar o nada", "Não a morte/ de que nunca poderemos falar", em que a insistente ideia de "nada" e a ideia de "morte" aparecem-nos imprecisas diante de descrições factuais ou imagens dotadas de maior precisão. O absoluto e o relativo, passam, portanto, a ser fluxos de percepção em comunhão, não mais opostos, como quer o senso comum; de modo que essa guinada perceptiva é resultado, antes de tudo, da estrutura poética em preterição, como mencionado inicialmente. O amor, claro, esteja, é o móbil possibilitador do poema, o "tu" interlocutor, com quem o sujeito lírico estabelece união, o possuidor de patas nos olhos, o de corpo cravejado por ponteiros translúcidos, o que tem sonhos navegados pelos barcos todos e, sobretudo, o ausente "sempre sempre" ao lado do sujeito da enunciação, como atesta o fim do poema. Momento único em que lemos versos não marcados pela preterição: "Não as palavras usadas/

\footnotetext{
${ }^{410}$ Tamanha é a recorrência metalinguística nos seus escritos, que aqui me limito a transcrever alguns versos que diretamente se relacionam com a temática corporal, erótica e amorosa: "Por dentro as palavras são viscosas" (SEIXAS, Cruzeiro. Obra poética (vol. I). Vila Nova de Famalicão: Quasi Edições, 2002, p. 155); “(...) o incêndio das palavras que nuas ainda te procuram.” (SEIXAS, Cruzeiro. Obra poética (vol. I). Vila Nova de Famalicão: Quasi Edições, 2002, p. 89); "Ensopado de palavras que se procuram/ desesperadamente/ que se olham nas esquinas/ apaixonadas (...)//Rompem a minha carne lentamente" (SEIXAS, Cruzeiro. Obra poética (vol. II). Vila Nova de Famalicão: Quasi Edições, 2003, p.151.).

${ }^{411}$ PIMENTA, Alberto. A magia que tira os pecados do mundo. Lisboa: Cotovia, 1995, p. 115.
} 
mas uma flor/ como uma faca", lemos entretanto, a mesma dissolução opositiva marcada pela preterição, pois embora a figura retórica em questão esteja ausente em "mas uma flor/ como uma faca", versos que se destacam por serem afirmativos, as qualidades de suavidade e afetividade da flor são mescladas às qualidades agressivas e violentas da faca. O amor, portanto, como eixo relacional que abarca os opostos, incluindo o elemento obscuro ou diabólico, mais ou menos conforme a visada de G. Bataille:

A ser verdade que "diabólico" quer essencialmente dizer a coincidência da morte com o erotismo, poder-nos-ia acontecer não reparar, se o diabo não passar ao cabo e ao resto de nossa loucura, se chorarmos, se grandes soluços nos despedaçarem - ou ainda se o riso irreprimível nos atacar - poder-nos-ia acontecer de não reparar que a preocupação, a obsessão da morte (da morte num certo sentido trágica e, não obstante, risível) surgem associadas ao erotismo nascente. ${ }^{412}$

Em outro momento, Cruzeiro Seixas pronuncia-se:

Nunca fui capaz de saber se, no "ménage à trois" imaginário e ideal que ocupou grande parte da minha vida, a terceira pessoa presente era deus ou o diabo. Talvez algumas vezes, os três, nos tivéssemos encontrado sobre o mesmo leito. Separar a alma do corpo é que parece trabalho criminoso. ${ }^{413}$

E Octavio Paz, em confluência:

Os antigos representavam o planeta Vênus, a luz da manhã, na figura de um jovem portador de uma tocha: Lúcifer (lux; lucis + ferre: portar). Para traduzir um trecho do Evangelho no qual Jesus fala de Satã como de "uma centelha caída do céu", São Jerônimo usou a palavra que designava a estrela da manhã: Lúcifer. Feliz deslizamento do significado: chamar o agente rebelde ao mais belo exército celestial, com o nome do arauto que anuncia o raiar do dia, foi um ato de imaginação poética e moral - a luz é inseparável da sombra, o vôo da queda. No centro da negritude absoluta do mal apareceu um reflexo indeciso: a luz vaga do amanhecer. Lúcifer: começo ou queda, luz ou sombra? Talvez um e outro. ${ }^{414}$

Em outro poema, amor e ódio é que aparecem reconciliados:

"O farol diz

${ }^{412}$ BATAILLE, Georges. As lágrimas de Eros. Lisboa: Sistema Solar, 2012, p. 19.

${ }^{413}$ MARTINS, Floriano, SEIXAS, Cruzeiro. "FLORIANO MARTINS | Cruzeiro Seixas - O horizonte sob desmedida" In: Agulha Revista de Cultura, sábado, 19 de setembro de 2015 http://arcagulharevistadecultura.blogspot.com.br/2015/09/floriano-martins-cruzeiro-seixas-o.html.

${ }^{414}$ PAZ, Octavio. A dupla chama: amor e erotismo. São Paulo: Siciliano, 1994, p. 133. 
odeio-te meu amor

odeio-te

meu amor

odeio-te

meu amor

odeio-te

meu amor

odeio-te

meu amor"415

\section{África 68}

Muito a propósito do que teria dito Alberto Pimenta:

(...) a língua separa arbitrariamente o que está junto: pode ser o odi et amo de Catulo, que ele próprio diz na sequência do poema não saber como é possível; é possível, porque só a falsidade ideológica da língua os separou, a esses dois siameses chamados "amor" e "ódio"; porque o que se opõe ao amor é o medo: pode ser a "morte de amor" $(\ldots)^{416}$

Ora, essas incursões entre o celestial e o diabólico entre o corpo e a alma, só fazem afirmar o modo expansivo com que a intersubjetividade se apresenta em Cruzeiro Seixas. André Breton, acerca da conjunção corpo e alma, é bastante perspicaz ao explicitar o sentido e os sentidos por assim dizer (uma vez que "a linguagem do coração" - o sentido -, seria justamente aquilo que se manifesta mediante os sentidos ou a sensorialidade):

(...) falar alto a linguagem do coração e dos sentidos. Esperemos que essa linguagem coloque novamente em apreço os grandes temas que lhe são próprios - como aquele que tende a consagrar a carne no mesmo grau que a alma, a fazê-las passar por não dissociáveis $(\ldots)^{417}$

Trata-se, portanto, de trânsitos entre fronteiras morais, sociais e, como veremos logo adiante, políticas e nacionais; trânsitos todos em direção de um mesmo propósito: a complexificação identitária que redunda na intersubjetividade como espaço de eleição. A esses trânsitos, creio ser possível relacionar a ideia de metamorfose (em

\footnotetext{
${ }^{415}$ SEIXAS, Cruzeiro. Obra poética (vol. III). Vila Nova de Famalicão: Quasi Edições, 2004, p. 167.

${ }^{416}$ PIMENTA, Alberto. O silêncio dos poetas. Lisboa: Edições Cotovia, 2003, pp. 79, 80.

${ }^{417}$ BRETON, André. Arcano 17. São Paulo: Editora Brasiliense, 1986, p. 38.
} 
outro momento do estudo já evocada), em conformidade com as palavras de Eliane Robert Moares: “A metamorfose seria então um imenso e interminável processo de 'dispersão do Eu no objeto exterior', para retomarmos as palavras de Breton sobre Arnin, cuja evidência inicial seria dada na duplicação do ser." fosse possível reinventar o mundo a partir de um grau zero no qual todos os elementos se encontrariam em constante transição."419 . Creio, entretanto, que, como contributo fenomenológico, a reinvenção do mundo ministrada pelo motor da transitoriedade foi bastante possível com os surrealistas.

Ainda um fato de interesse a ser evidenciado no que tange à questão intersubjetiva, fato muito característico na escrita e na pintura de Cruzeiro Seixas: trata-se das figurativizações do mar e de suas adjacências, insistentemente retratados, conforme os versos do poema transcrito: "Não os barcos todos/ navegando os teus sonhos", "não o local para sermos as chamas vegetais/ rompendo o mar", "Não o mar cruzado por comboios/ não o mar sentado à nossa mesa/ não o mar dentro das nossas cartas/ não o mar com janelas abertas/ sobre paisagens fechadas.", "Não o marítimo caminhando para o fundo do mar". A frequência de tais imagens na criação de Cruzeiro Seixas revela uma maneira muito particular de se apropriar de um tema português tão recorrente, tema identitário nacional que aqui ganha contornos surrealistas (o que não deixa de ser uma subversão, posto que é uma nova proposta de visitação da tradição). Embora, de modo geral, o surrealismo seja visto - na esteira de como recebemos as vanguardas do início do século - como um movimento iconoclasta e de recusa completa da tradição e do passado que o precedeu, essa visão apenas em parte se confirma: se, por um lado, é inegável que o surrealismo tenha promovido uma rebelião contra as formas de organização do pensamento moderno, contra os valores morais instituídos e contra o propósito esteticista da arte, por outro lado, também é inegável a recorrência à tradição. A exemplo de Cesariny, que compôs uma série de quadras inspiradas na tradição oral - além de haver organizado uma antologia de literatura de cordel - Cruzeiro Seixas apropria-se do mar. Seguem alguns trechos de poemas recolhidos entre uma diversidade imensamente maior que não seria conveniente esgotar aqui: "A cor do sal”, "as mãos do mar", "passos extremos/ no limite do mar",

\footnotetext{
${ }^{418}$ MORAES, Eliane Robert. O corpo impossivel. São Paulo: Iluminuras: 2005, p. 133

${ }^{419}$ Idem, p. 76.
} 
"No peixe/ infinito/ o mar morre", "os sentimentos mais líquidos", "Assim alcançam novos mares no seu sonho", e, enfatizando o erotismo: "o peixe que terminava em flor erecta", "tantas vezes quantas o mar entrou na minha cama". Tal obsessão pelo tema, em parte se justifica pela ideia de trânsito (também presente em Cesariny), que em Cruzeiro Seixas incide mais propriamente sobre o continente africano, por onde, por circunstâncias de sua trajetória, pôde se deslocar e, portanto, deslocar o lugar eurocêntrico identitário que, como português, estaria condicionado a ocupar.

Abaixo, seguem reproduzidas algumas de suas serigrafias, em que as águas, as caravelas e os peixes assumem lugar de destaque:

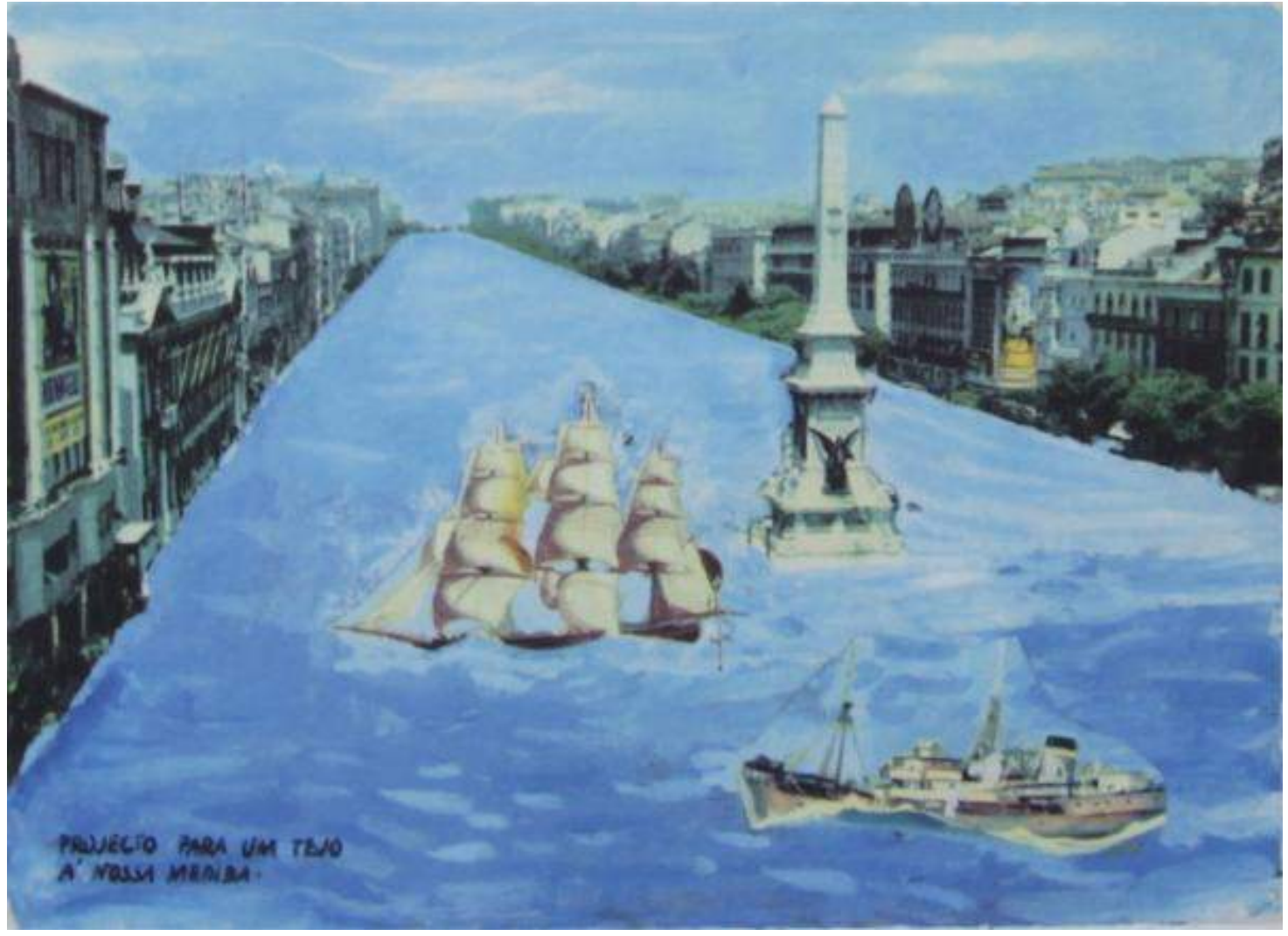

(Projecto para um Tejo à nossa medida, 1966) 


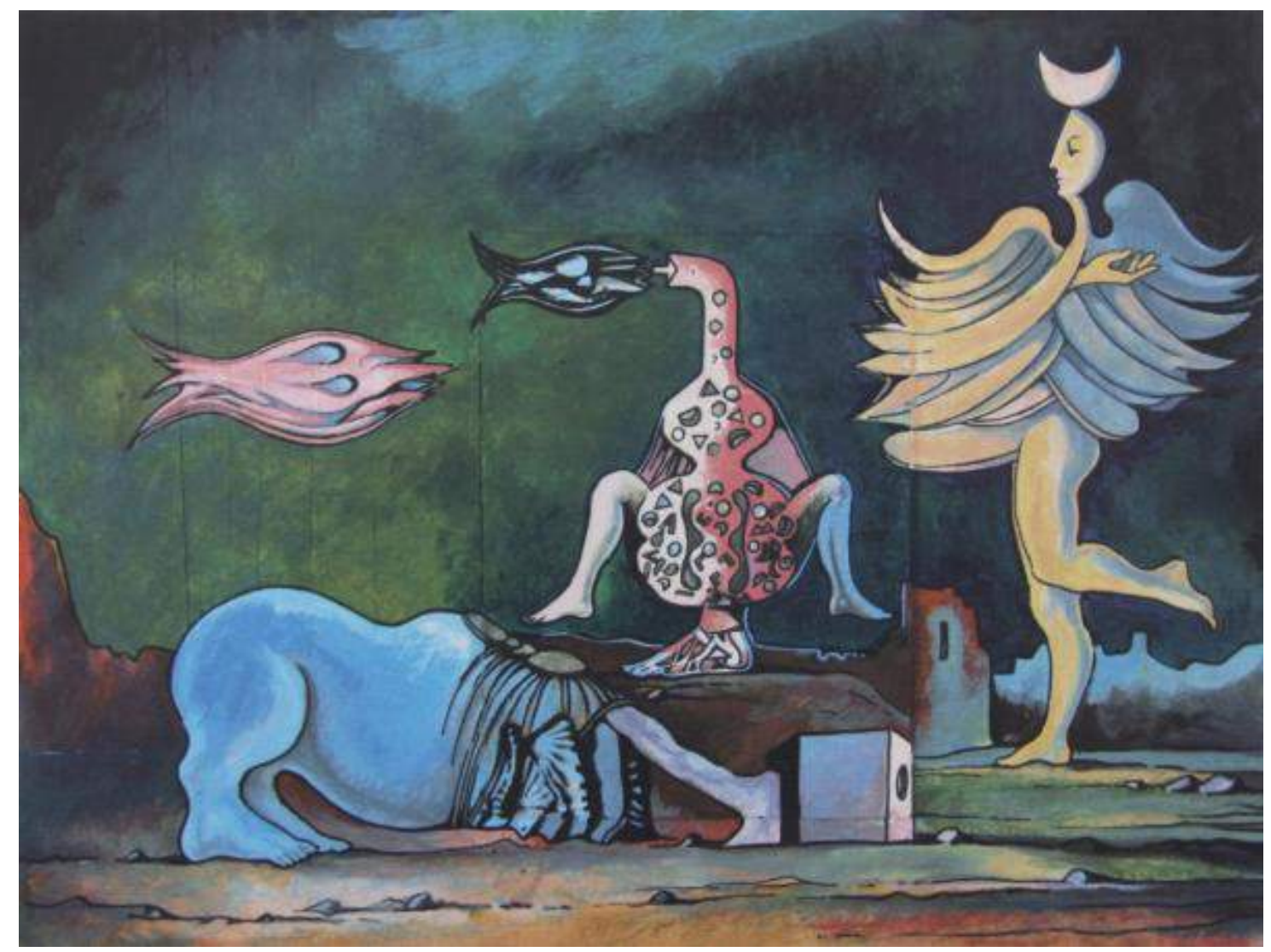

(No dia seguinte ao nosso casamento, 1967) 


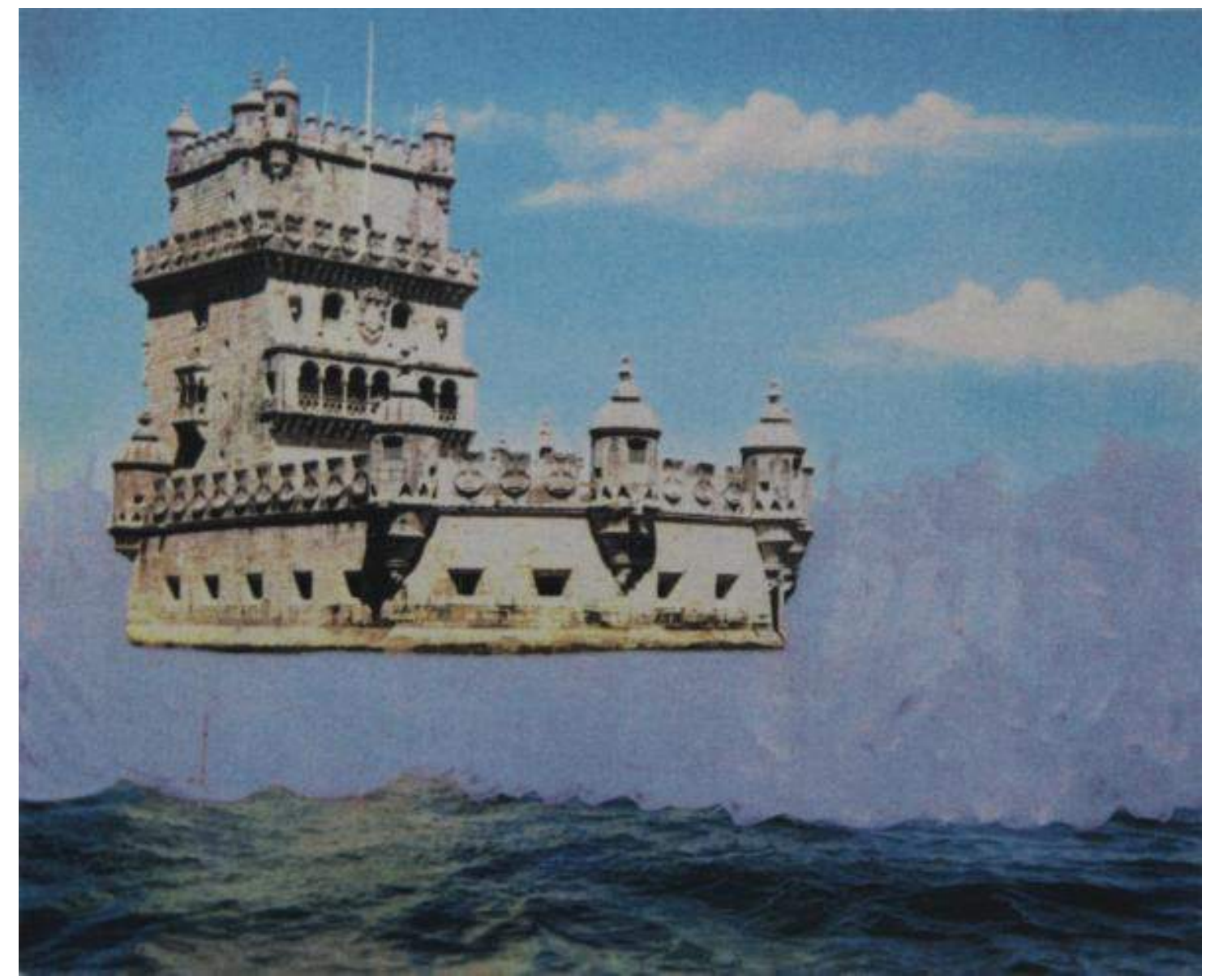

(Recordação de Lisboa em forma de postal, 1970)

Sobrea ideia de trânsito, interessa-me particularmente o rompimento das fronteiras nacionais (e identitárias decorrentes de tal): há uma diversidade de declarações de Cruzeiro Seixas - além de manifestações poéticas - em que o deslocamento identitário incide diretamente sobre a questão nacional e racial. Sobre a sua experiência em Angola, segue este longo trecho:

E volto às histórias da história. Devido às carências de casa de meus pais, alistei-me na marinha em 1949. O apelo de África já vinha da infância, em que se falava lá em casa, com lágrimas abundantes, na morte por biliose de um tio que para lá tinha partido em louca aventura, no tempo em que para África só iam os condenados, e os loucos. Nos portos em que toquei na primeira viagem, de São Tomé a Goa, e de lá a Timor e Macau, o espetáculo nos cais era ainda o da escravatura; gente batida no fundo dos porões. Em Angola, os colonos designavam por graça os trabalhadores da estiva como "voluntários à corda", pois alguma vezes ainda vinham amarrados uns aos outros... Via eu tudo isto com os olhos de alma bem abertos, de espanto, e de raiva. Não precisei de fazer a guerra, para aprender onde estava a razão... Em Angola me fixei, e percorri-a 
apaixonadamente. África atraía-me, quando era Paris que atraía intelectuais e artistas. A verdade é que parece que esses se enganaram, e que é grave o seu erro. $\mathrm{O}$ futuro que então teceram, infelizmente era já passado. Na verdade o Chiado não me tinha deixado saudades por aí além, sendo para o meu gosto demasiadamente literário e artístico. Tinha, isso sim, saudades de dois ou três amigos... que infelizmente, afinal era do Chiado e do seu miniteatro que gostavam muito... Em Angola, os mais variados trabalhos e os mais mal remunerados foram pretexto para incursões ao "interior", só com um ajudante geralmente de cor, em carripanas de ocasião, por inimagináveís caminhos de lama, de areia, cortados por extensíssimas queimadas, sinuosos leitos de rios com caprichosas jangadas, e aquilo que se chamava pomposamente hotéis, e onde os lençóis não eram mudados desde o tempo de Paulo Dias de Novais. Estas viagens eram para mim a plenitude das plenitudes; em todos os momentos livres, recolhia objetos etnográficos, tão belos e significativos como as longas negociações que acompanhavam a sua aquisição. A alma daquela civilização (porque de uma civilização se trata...) ficou a fazer parte, a mais profunda, de mim, mas nego-me a posições políticas, tão espetaculosas como transitórias. Estas viagens (como a maior parte dos livros que li...) apenas vieram confirmar o que eu já sabia. Realizei em Luanda duas exposições que levantaram dos maiores movimentos de opinião (de que de resto Cesariny dá notícia e apresenta alguns documentos, na sua $A$ intervenção surrealista, editada pelo Ulisseia em 1966); e porque uma dessas exposições era colocada sob a evocação do poeta negro Aimé Cesaire, fui chamado à PIDE. Isso se repetiria quando mais tarde, funcionário do Museu de Angola, lhe procurei dar alguma vida organizando um salão de pintura, onde pendurei um dos primeiros Malangatanas. Um "preto" num salão de pintura, era coisa inadmissível então! É de fato fácil estabelecer uma cronologia desta minha consciência e paixão. A minha primeira exposição foi em 1953. É em 1950 que o livro de Luandino Vieira provoca o escândalo que provocou. Só em 1974 Spínola publica Portugal e o futuro; e até abril do mesmo ano morreu gente que não sabia porque morria... Quando me apercebi que tinha que pegar numa arma contra brancos ou contra pretos, foi com enorme tristeza que precipitadamente regressei à Europa. ${ }^{420}$

Ora, o relato é ele mesmo um atestado de fusão entre percepções diversas: um português branco que se vê na encruzilhada, intimado a guerrear a favor dos brancos ou a favor dos negros (a essa altura já se pode dizer que Cruzeiro Seixas era mulato...), um português censurado em Portugal por exposições e parcerias com artistas negros angolanos em Angola. Trata-se de uma situação interseccional, e tudo leva a crer que a

\footnotetext{
${ }^{420}$ MARTINS, Floriano, SEIXAS, Cruzeiro. "FLORIANO MARTINS | Cruzeiro Seixas - O horizonte sob desmedida" In: Agulha Revista de Cultura, sábado, 19 de setembro de 2015 http://arcagulharevistadecultura.blogspot.com.br/2015/09/floriano-martins-cruzeiro-seixas-o.html.
} 
intersubjetividade atravessada pelas questões nacionais passa a ser a sua condição subjetiva. Embora não pronunciado, o amor, indubitavelmente, é o elo que permite a fusão entre tais percepções determinadas pelo contexto político/social e geográfico que envolve Portugal e África a essa altura, e creio ser possível afirmá-lo, uma vez que o primeiro contato com África, conforme relatado, ocorre de uma narrativa familiar com grande carga afetiva, além disso, "o espanto e a raiva" provocados pela indignação diante da situação dos negros, induzem a interpretar que o amor é aquele que teria permitido o poeta a "aprender onde estava a razão...". A respeito do impacto provocado pelo "espetáculo da escravatura" inscrito no relato, e as consequentes incursões identitárias que essa vivência possibilitou, segue passagem de MEU PRIMEIRO POEMA DE ÁFRICA (Luanda, 52), que muito vem a calhar:

“(...)

Mas nem eu sei o que sou, branco por fora e negro por dentro, como tu num beco sem outra saída que não seja no sentido vertical... $(\ldots)^{, 421}$

A verticalidade do sentido parece-me dado de relevância para se considerar aberto o trânsito entre dentro e fora de que tanto nos fala Merleau-Ponty (no caso do filósofo, em termos de subjetividade e objetividade), de modo que o deslocamento geográfico é propulsor de um deslocamento subjetivo e, se Cruzeiro Seixas fala em termos de brancura exterior e negritude interior, a auto definição deve ser considerada apenas em termos daquilo que seria visível em relação à percepção, uma vez que, no que diz respeito aos termos de identidade e existência:

(...) essa vida estranha [a do outro] é uma vida aberta, assim como a minha com a qual ela se comunica. Ela não se esgota num certo número de funções biológicas ou sensórias. Ela anexa a si objetos naturais desviando-os de seu sentido imediato, ela constrói-se utensílios, instrumentos, ela se projeta no ambiente em objetos culturais. ${ }^{422}$

${ }^{421}$ SEIXAS, Cruzeiro. Obra poética (vol. II). Vila Nova de Famalicão: Quasi Edições, 2003, p. 13. 
Retomo ainda mais uma vez os dizeres de Merleau-Ponty: “(...) há indivisão do meu corpo, do meu corpo e do mundo, do meu corpo e dos outros corpos entre si (...) Projeção - introjeção" ${ }^{423}$. Também nesse sentido, Cruzeiro Seixas faz a crítica do encerramento que o surrealismo assumiu em relação a ideia de nação: “(...) há um grupo em Paris, há um grupo em Madrid, na Holanda... há imensos grupos. Mas esses grupos, é muito curioso, vivem como pequenas pátrias. A pátria é mais importante que o surrealismo. Vivem fechados dentro das pátrias. ${ }^{\text {424 }}$. O alargamento subjetivo no qual Cruzeiro Seixas se engaja (no sentido nacional e, dado o contexto angolano em que esteve inserido, também racial), me parece extremamente subversivo num momento histórico em que dificilmente se divulgavam ideias de livre transito e de atravessamento de fronteiras (temas, ainda hoje bastante obscurecidos).

Ainda sobre a questão do rompimento de barreiras, vale trazer o homoerostismo como manifestação (menos ostensiva, se comparada ao caso Cesariny), que frequentemente, ocorre mediante a metáfora especular (também aqui, vale a remissão a Cesariny, em poema lido há pouco: "Nunca estive tão só diz o meu corpo e eu rio-me"): "um espelho que se estende entre mim e ele/ (...)/ quanto está vaga a noite/ que por acaso se chama Carlos." 425 , "Aquele espelho que queria fazer amor comigo/ é o mesmo que já não me quer olhar?" ${ }^{26}$, e, num intertexto com Breton, ainda esta composição especular: "colocar l'amour fou diante de l'amour fou" "427. O espelho, portanto, como a grande metáfora identitária e amorosa ou, para obedecer aos modos de complexificar o eixo identidade/alteridade, como a grande metáfora que leva às últimas consequências os desvios e insuficiências que a ideia do idêntico comporta:

\footnotetext{
${ }^{422}$ MERLEAU-PONTY. Maurice. Fenomenologia da percepção. São Paulo: Martins Fontes, 1996, p. 474.

${ }^{423}$ MELEAU-PONTY, Maurice. A natureza. São Paulo: Martins Fontes, 2006, p. 441.

${ }^{424}$ SEIXAS, Cruzeiro. "Entrevista" In: Revista Todo mundo ENTRE ninguém, Lisboa: 2014, número 5, inverno, p. 66.

${ }^{425}$ SEIXAS, Cruzeiro. Obra poética (vol. II). Vila Nova de Famalicão: Quasi Edições, 2003, p. 415.

${ }^{426}$ Idem, p. 412.

${ }^{427}$ Idem, p. 203.
} 
“(...)

Olho-me em função do que vejo nos outros

quero dizer

que os outros são meu espelho.

Sou por compensação e por reação

e assim o espelho de feira

o desequilíbrio cósmico

não me é dado.

$(\ldots)$

Entre mim e mim

há o infinito da proximidade.

$(\ldots)$

Será que os espelhos

agem por medo

em estado de pânico?

Cada peito uma rocha

e tudo espelhando a dissonância

$(\ldots)^{, 428}$

Conforme Cruzeiro Seixas: "Os outros são meu espelho", e de tal modo o processo de identificação é empenhado que o outro converte-se no próprio sujeito: "Entre mim e mim/ há o infinito da proximidade". Novamente a infinitude como marca do que estaria sempre a possibilitar o trânsito, a transformação, marca de uma eternidade às avessas, uma vez que supõe a metamorfose como única característica perene.

Ainda sobre a subversão identitária: "Pela janela/ lá vem a estrada que me segue/ e fujo/ fujo dos meus dentes/ dos meus olhos/ das mãos que nunca foram minhas mas sim dos outros" ${ }^{429}$. As mãos, como eu disse em outro momento, parte do corpo diretamente associada à escrita e, mais além, aos ofícios e atividades humanas, são aqui deslocadas do sujeito da fala, que parece fugir de si próprio em direção ao exterior, num exercício poético que é também uma forma de dissipar-se diante do

\footnotetext{
${ }^{428}$ SEIXAS, Cruzeiro. Obra poética (vol. I). Vila Nova de Famalicão: Quasi Edições, 2002, p.102-104.

${ }^{429}$ Idem, p. 116.
} 
espelho, instrumento que possibilitaria a duplicação, ou mais, a expansão.

Em termos de ultrapassagem dos limites que usualmente definem o sujeito, é pertinente pensar com André Breton

(...) este estado de graça [o estado amoroso] resulta da conciliação em um único ser de tudo o que pode ser esperado de fora e de dentro, que nasce do instante único no qual no ato do amor a exaltação no auge dos prazeres dos sentidos não se distingue mais da realização fulgurante de todas as aspirações do espírito. ${ }^{430}$

Ora, tais aspirações aparecem manifestas do seguinte modo em Cruzeiro Seixas:

"Sei que o teu sangue circula por dentro do meu sangue

e que nas minhas lágrimas ressequidas

tu navegas obscuros países.

E então glorifico as descobertas

as grandes navegações do mistério

a abordagem do corpo inteiro

o recorte da costa

o tríptico aberto e fechado

solenissimamente magicamente

$(\ldots)^{, 431}$

A pulsão fusional inscrita nos versos precedentes só faz ressaltar o percurso exterior/interior tão presente na poética de Cruzeiro Seixas, o que, neste poema, ocorre mediante a figuração do sangue que, conforme já ressaltado em outro momento, é elemento vital e constantemente em trânsito no corpo humano. Dele advém a sugestão de intimidade, dada a interioridade que ocupa na fisiologia dos corpos. Para além dessa evidência, na qual insisto, importa atentar para os termos "obscuros" e "mistério" que precedem (na ordem da versificação), “a abordagem do corpo inteiro”, já que também esses termos difusos são recorrentes na poética em questão, a exemplo do seguinte pronunciamento de Cruzeiro Seixas:

Deverei dizer ainda que conheci gente em que o sexo era muito mais

\footnotetext{
${ }^{430}$ BRETON, André. Arcano 17. São Paulo: Editora Brasiliense, 1986, p. 107.

${ }^{431}$ SEIXAS, Cruzeiro. Obra poética (vol. I). Vila Nova de Famalicão: Quasi Edições, 2002, p. 189.
} 
inteligente que o cérebro? ${ }^{432}$ Mas nada do que não tenha mistério me pode interessar; o mistério que persiste em cada corpo que amamos, e o torna maior que o universo, mais agitado que o mar, mais azul que o céu. $\mathrm{O}$ corpo é a paisagem que a moldura não contém. Aos 70 anos, parece-me que os meus olhos foram ainda mais ávidos de beleza que o meu corpo, que o foi tanto. Incrível a quantidade de caminhos que há para nos levar a sítio nenhum! E aqui surge a pergunta que me parece inevitável hoje; como se faz amor com um marciano $?^{433}$

O trecho transcrito me parece muito adequado para o presente propósito, já que intersecciona corpo, mistério e mar. Este último elemento listado, o mar, merece especial atenção, uma vez que me parece ser ele o eixo relacional (e portanto a grande metáfora amorosa intersubjetiva) que abarca a proposta transfronteiriça que proponho como mote de leitura. O mar é o símbolo do mistério humano, mais desconhecido e menos mapeado do que o céu pela categorização científica. Sendo mistério, é caminho em quantidade imensa ("Incrível a quantidade de caminhos que há para nos levar a sítio nenhum!"'), é o lugar que gramaticalmente poderia ser expresso pela preposição entre (daí o paralelo entre o mar e a experiência de Cruzeiro Seixas em África, que permitiu que ele se dissesse branco por fora e negro por dentro) implica em trânsito e movimentação, é o próprio lugar da intersubjetividade amorosa. A pergunta que encerra o trecho ("como se faz amor com um marciano"), vem coroar o desejo infinito de alteridade (e a infinitude, aqui, lida em termos de perversão, uma vez que pode-se considerar perverso tudo aquilo que excede os limites da normalidade, bem como o infinito excede os limites do finito), isto é, a alteridade elevada ao grau máximo que a imaginação humana pôde conceber, como proposta de interseção subjetiva amorosa. Conforme as palavras de Breton: “Amor, (...) Um dia virá em que o homem saberá reconhecer-te como seu único senhor e prestar-te honras até mesmo nas misteriosas perversões em que o envolves." ${ }^{434}$, eis a maior de todas as perversidades inscrita no desejo de renovação infinita do trajeto em direção ao outro.

\footnotetext{
${ }^{432}$ De modo semelhante, manifesta-se em um de seus desaforismos: “...O sexo nunca foi analfabeto..." (SEIXAS, Cruzeiro. Homenagem à realidade. São Paulo: Escrituras, 2005, p. 125.), qualificando, transgressivamente, o corpo e a atividade erótica com propriedades que tradicionalmente (e conforme a herança cartesiana) são da alçada do pensamento.

${ }^{433}$ MARTINS, Floriano, SEIXAS, Cruzeiro. "FLORIANO MARTINS | Cruzeiro Seixas - O horizonte sob desmedida" In: Agulha Revista de Cultura, sábado, 19 de setembro de 2015 http://arcagulharevistadecultura.blogspot.com.br/2015/09/floriano-martins-cruzeiro-seixas-o.html.

${ }^{434}$ BRETON, André. Amor Louco. Lisboa: Editorial Estampa, 1971, pp. 99, 100.
} 


\subsection{Amor/amores de qual subjetividade?}

Dos trânsitos entre identidade e alteridade que foi possível flagrar mediante a leitura dos poemas, creio ser possível dizer que, no caso dos três poetas estudados, seria impossível supor qualquer fixação ou imobilidade dos polos interacionais. Há gradações, ao que me parece, circunscritas numa maior definição de fala, no caso de Herberto Helder, que oscila seus modos de expressão entre masculinidade e feminilidade, sendo a masculinidade o lugar de maior preponderância subjetiva. Em Cesariny a questão dos gêneros parece partir de um empenho na dissolução dos binarismos, seja mediante as intersecções entre feminino e masculino, seja pelo homoerotismo, muito embora o binarismo ainda apareça como ponto de partida discursivo para a subversão operada. Em Cruzeiro Seixas, a questão masculinidade/feminilidade é suspendida em função de uma manifestação subversiva que decorre do ato poético, isto é, se Cesariny conversa com a tradição binária de divisão dos gêneros para, a seguir, dissolvê-la, Cruzeiro Seixas vai direto à dissolução e abarca, para além da temática homossexual (que figura de modo menos engajado do que no caso de Cesariny), também a temática nacional e racial, dada sua experiência em África.

O amor, indubitavelmente, aparece nos três casos como força subversiva que rompe com as delimitações de ordens diversas a serviço do cerceamento identitário: o que está em questão, de fato, é a incursão em poéticas de risco, cuja identidade é o alvo a ser atingido em nome de uma maior flutuação subjetiva (considerando-se as gradações implicadas em cada caso). Como bem formulou Herberto Helder:

\section{O que afinal separa o mundo interior do exterior não é uma barreira, sim um diafragma - a superfície transparente onde afinal se anula a distinção entre interior e exterior. O que está por dentro anuncia, denuncia, prenuncia, pronuncia o que está por fora. $\mathrm{E}$ ao contrário. Este diafragma imaginário não põe em comunicação o mundo interior com o exterior, o que pressuporia isolamento ou ruptura de ritmo - mas comunica. ${ }^{435}$}

De modo que entre interior e exterior, entre subjetividade e objetividade, entre identidade e alteridade há apenas uma membrana flexível que permitiria a passagem/comunicação. A esta membrana, de acordo com Herberto Helder, nomeada como corpo - o diafragma - poderíamos chamar amor.

${ }^{435}$ HELDER, Herberto. Photomaton \& Vox. Lisboa: Assírio \& Alvim, 2006, p. 135. 
5. Considerações Finais 
Muito sucintamente, e sem me ocupar em fazer uma revisão exaustiva do desenvolvimento desta pesquisa, proponho algumas reflexões que lancem considerações a partir das relações aqui propostas entre subjetividade, corpo e linguagem, bem como seus aspectos subversivos. Antes de abrir as reflexões para as considerações supramencionadas, entretanto, proponho uma brevíssima síntese do percurso traçado a partir das intersecções empenhadas.

Acredito que com a proposta fenomenológica - tal como apresentada por Maurice Merleau-Ponty - foi possível atravessar a rede poética que aqui propus: a um só tempo manifestar a recusa diante da cultura instituída e do racionalismo (hostilizados consensualmente pelos surrealistas e por Herberto Helder), bem como afirmar o corpo como manifestação de uma existência balizada pela criação poética. Nesse sentido, a subjetividade é, aqui, não apenas recusada como evidência resultante do ser-pensante cartesiano, mas sobretudo entendida como expressão afirmativa- o que, de algum modo, vai na contracorrente de parte considerável da filosofia contemporânea que defende a diluição ou apagamento do sujeito -, uma vez que, embora seja contingencial/massa amorfa em constante movimento de metamorfose, implicante/implicada pelas alteridades com as quais estabelece contato, a subjetividade é atestado de existência e âncora do ser no mundo, sempre que considerada como manifestação corpo em atividade perceptiva, conforme a linha teórica perseguida.

Feito esse brevíssimo sumário, passo, portanto, a algumas considerações que projetam a presente pesquisa em direção a uma nova constelação de abordagem. E, se digo "nova", não tenho por objetivo considerar as reflexões anteriores obsoletas, mas assim a qualifico, pelas expansões das possibilidades de tratamento. Trata-se, de fato, de uma rede de abrangências, em outras palavras, de um modo de adicionar contornos diversos ao recorte posto que é parte de um processo reflexivo inesgotável e em constante fermentação - dadas as leituras mais recentes que serviram de impulso a um contínuo envolvimento, seja com os temas levantados, seja com as respectivas poéticas de interesse (consideradas em suas afinidades e particularidades). Constelação essa, que certamente encontrará o tempo-espaço adequado para o devido desenvolvimento.

A começar pela subversão instaurada, para além dos fatos insistentemente trabalhados que incidem sobre a destituição da lógica, moral e cultura tradicionais nos moldes evidenciados pelos três poetas - , creio ser possível falar com Maurício Salles Vasconcelos a respeito de uma ética da contemporaneidade. Ao discorrer acerca do legado de Gertrude Stein, Maurício afirma: 
Proeminente se torna um solo a um só tempo combinatório e englobador do qual se depreende uma insurgência que se espraia entre individuação e conjunto. A diferença como norteamento propicia arranjos insuspeitados a partir das possibilidades mais diversas de contato e contextualização. ${ }^{436}$

Ora, tal ética, sumariamente exposta pelo investigador, parece-me ser plenamente adequada às reflexões empenhadas ao longo dos capítulos. Tocar no ponto da "diferença como norteamento", permite que todas as noções advindas da ideia de subjetividade, identidade e relação sejam repensadas mediante essa diversidade abrangente inscrita nas combinatórias possíveis, além de lançar os modos de constituição subjetiva para terrenos propriamente insurgentes, como bem pontuado por Maurício. Um passo além e é de uma ética que se trata, ela mesma condicionada por uma estética (ou uma poética - termos que, aqui, dispensam variações de significação, uma vez que vêm sendo pensados em função da existência neles imbricada) que lhe dá forma mediante as incursões subversivas. Ainda sobre as tais insurgências das quais essa ética/estética é propulsora, convém retomar as palavras de Haroldo de Campos que serviram de epígrafe para este trabalho:

No exercício rigoroso de sua atividade, a crítica haverá de convocar todos aqueles instrumentos que lhe pareçam úteis, mas não poderá jamais esquecer que a realidade sobre a qual se volta é uma realidade de signos, de linguagem portanto. ${ }^{437}$

E pensá-las juntamente com a reflexão de Max Bense:

(...) observa-se no trato diário com que satisfação cada cidadão interpreta a imutabilidade de sua linguagem no sentido da estabilidade do seu mundo. A desconfiança contra os experimentos na esfera inteligível tem, portanto, origens sociais. É a desconfiança da classe, que não gosta de ver em perigo sua hierarquia, seus distintivos, seus emblemas. Nem sequer no domínio da língua que se fala. ${ }^{438}$

A subversão ou insurgência tão ressaltada, portanto, é antes de tudo uma

\footnotetext{
${ }^{436}$ VASCONCELOS, Maurício Salles. Exterior. Noite-Filosofia/Literatura. Bauru: 2015, p.221.

${ }^{437}$ CAMPOS, Haroldo de. Metalinguagem \& outras metas. São Paulo: Perspectiva, 1992, p. 11.

${ }^{438}$ BENSE, Max Apud CAMPOS, Haroldo de. Metalinguagem \& outras metas. São Paulo: Perspectiva, 1992, p. 22.
} 
subversão de linguagem: mudar a linguagem significa, em última instância, mudar os modos de se relacionar consigo próprio, com o outro e com os contextos de modo amplo. Daí que voltamos à linguagem como o solo sobre onde se assenta qualquer ontologia; daí não ser possível dissociar linguagem e existência; daí, portanto, a fusão tão primordial entre linguagem e corpo. A tal importância conferida à linguagem, os três poetas estiveram atentos, fato que redundou, na pesquisa, em análise da metalinguagem implicada nos modos de constituição subjetiva mediante a poesia. Mas a questão do corpo e suas imbricações linguísticas dão um salto além, se pensarmos, juntamente com Ricardo Vasconcelos, no aspecto metafórico de que também se revestem as figurações do corpo. Em estudo dedicado à poesia de Luís Miguel Nava que incide fortemente na ideia de subjetividade corporal - , o pesquisador afirma que, por meio da possibilidade que a metáfora (como artificio de leitura) enceta, a literariedade das imagens do corpo é redimensionada, ao possibilitar uma amplitude do sensível pelos sentidos (ou pelas interpretações, isto é, pelo alargamento de um termo a viabilizar o acréscimo de significações) que estas mesmas imagens proporcionam como modo de expansão semântica ${ }^{439}$. Também Jean-Luc Nancy se pronuncia, de maneira provocativa, a esse respeito: "Porquê e como uma ou várias diferença(s) dos 'sentidos' em geral, e entre os sentidos sensíveis [sens sensibles] e o sentido sensato [sens sensé]?"440. Ora, de acordo com tais perspectivas, a análise metalinguística que desenvolvi ao longo da leitura dos poemas, depende, em parte, dessa conjunção entre sentido e sentidos. Em outras palavras, quando leio "mão" ou "boca" como termos que reenviam à escritura poética, nada mais faço do que evidenciar um dos sentidos metafóricos dos termos em favor de uma consciência e pronunciamento manifestos de linguagem, atravessados, sem dúvida, pela relevante fusão entre corpo/existência e poesia.

Um passo além, e a suposição de que o corpo como percepção e pilar subjetivo (conforme Merleau-Ponty) é sempre uma manifestação do erotismo (de modo que poderíamos falar numa linguagem erótico-amorosa em Herberto Helder, Cesariny e Cruzeiro Seixas). Daí ser possível afirmar que o erotismo enquanto expressão orgânica/concreta é também expressão sentimental/abstrata:

\footnotetext{
${ }^{439}$ Cf. VASCONCELOS, Ricardo. Campo de relâmpagos: leituras do excesso na poesia de Luís Miguel Nava. Lisboa: Assírio \& Alvim, 2009, pp. 233, 235, 239-240.

${ }^{440}$ NANCY, Jean-Luc. À escuta. Belo Horizonte: Edições Chão da Feira, 2014, p. 13.
} 
O acesso à carne do corpo, na opinião de Philippe Sollers, é sempre uma forma de erotismo: "seul l'ertisme nous donne accès à sa chair, c'est-à-dire, non pas à une "substance", mais à l'inscription qui est la sienne, à l'excès, qu'est par rapport à ele-même cette inscription insaissiable" (Sollers, 1968: 121). Isto é, o trabalho da carne é da ordem da transcrição, tem como limites a nossa própria existência e a nossa própria forma, e não nos referimos especificamente à estrutura anatómica, alicerce da visão que temos dessa forma, mas à imagem mental que fazemos do nosso interior, dos espaços que ocupamos. Perceber-se-à bem que espaços ocupa este trabalho da carne, se considerarmos a relação sexual e os lugares de interioridade que nela experimentamos. $^{441}$

Portanto, trata-se de um corpo tematizado mediante poemas, mas trata-se também de um corpo vivenciado nas suas propriedades existenciais de auto/heteroreconhecimento, com reenvios sucessivos para o caráter erótico-escritural e percepcional: “(...) até metaforicamente, o corpo é tanto corpo como mais do que ele, sendo importante por permitir a intensidade da vivencia." ${ }^{\text {442 }}$. Talvez seja justamente nessa possibilidade metafórica que a poesia (e o próprio corpo, conforme as reflexões de Ricardo Vasconcelos) mais se manifeste enquanto transcendência: do sentido aos sentidos, de maneira que estes estariam sempre a subverter a imanência que, de partida, supõe-se característica primordial da matéria.

Dos impossíveis existenciais que a linguagem atualiza, magistralmente se apropriaram os surrealistas, bem como Herberto Helder, para os quais a evidência da linguagem erótica (porque corpo, porque subversão) é poder, sobretudo, de modificar o discurso da autoridade (que prescreve possibilidades e impossibilidades) numa operação que transcende os limites do corpo ele mesmo (e, sendo assim, da percepção do sujeito acerca de si.

\footnotetext{
${ }^{441}$ VASCONCELOS, Ricardo. Campo de relâmpagos: leituras do excesso na poesia de Luís Miguel Nava. Lisboa: Assírio \& Alvim, 2009, p. 67.

${ }^{442}$ Idem, p. 248.
} 
6. Bibliografia 


\subsection{Bibliografia base}

- ARTAUD, Antonin. Escritos de Antonin Artaud (tradução, seleção e notas: Claudio Willer). São Paulo: L\&PM, 1983.

- _ _ Heliogabalo ou o anarquista coroado (trad. Mário Cesariny). Lisboa: Assírio \& Alvim, 1991.

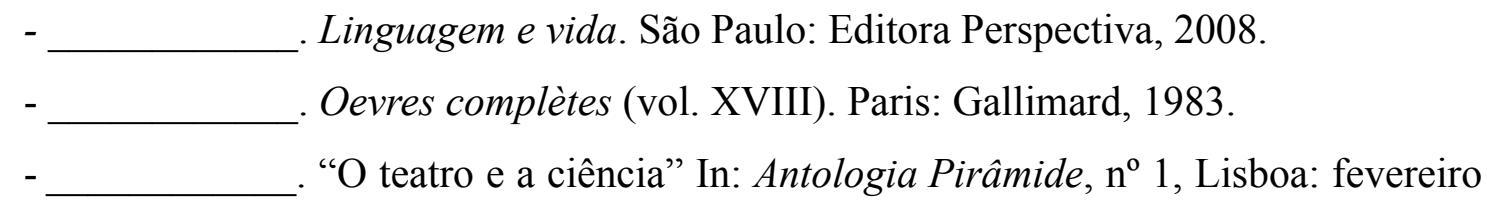
de 1959, p. 6-9.

- _. O teatro e seu duplo. São Paulo: Martins Fontes, 1999.

- BRETON, André. Amor louco. Lisboa: Editorial Estampa, 1971.

- __ Arcano 17. São Paulo: Editora Brasiliense, 1986.

- _ _ Entrevistas. Lisboa: Edições Salamandra, s/d.

- _. Manifestos do surrealismo. São Paulo: Editora Brasiliense, 1985.

-_ Nadja. São Paulo: Cosac Naify, 2007.

- CESARINY, Mário A Cidade Queimada. Lisboa: Assírio \& Alvim, 2000.

- _ _ A Intervenção Surrealista, Lisboa: Assírio \& Alvim, 1997.

- _ _ As mãos na água a cabeça no mar. Lisboa: Assírio \& Alvim, 1985.

- _ _ Burlescas, teóricas e sentimentais. Lisboa: Editorial Presença, 1972.

- _ _ Cartas de Mário Cesariny para Cruzeiro Seixas. (Org.: Perfecto E.

Cuadrado, António Gonçalves, Cristina Guerra). Lisboa: Assírio \& Alvim (Documenta), 2014.

- _. Manual de prestidigitação. Lisboa: Assírio \& Alvim, 2008.

- _. O Virgem Negra. Lisboa: Assírio \& Alvim, 1989 (1ª Ed.).

- _. Pena Capital. Lisboa: Assírio \& Alvim, 2004.

- _ _ Primavera autónoma das estradas. Lisboa: Assírio \& Alvim, 1980.

- __ Uma grande razão: os poemas maiores. Lisboa: Assírio \& Alvim, 2007.

- GONÇALVES, Eurico. "Cartaz da exposição de Cruzeiro Seixas na Galeria de Arte Moderna" (28 de maio - 17 de junho de 1982).

- HELDER, Herberto. Apresentação do rosto. Lisboa: Ed. Ulisseia, 1968. . Cena vocal sobre fundo visual de Cruzeiro Seixas. Lisboa: Diário de

Notícias, 19 de junho de 1980. (http://www.triplov.com/herberto_helder/Cruzeiro- 
Seixas/index.html).

- _ _ _ "Cesariny sombra de almagre”. A Phala, 1\#, 2007.

- _ _ Doze nós numa corda - poemas mudados para o português. Lisboa:

Assírio \& Alvim, 1997.

- Edoi Lelia Doura: antologia das vozes comunicantes da poesia moderna portuguesa. Lisboa: Assírio \& Alvim, 1985.

. "Entrevista". Jornal de Letras e Artes n. ${ }^{\circ}$ 139, de 17 de Maio de 1964. (http : // editora - afrodite. blogspot. com/ 2007/09/entrevista-herbertohelder.html)

. "Eu que apareci acidentalmente vivo" In: A IDEIA. Lisboa: no 73/74, p.34-35, outono de 2014.

- _ _ Fonte. Lisboa: Assírio \& Alvim, 1998.

- _ _Herberto Helder: entrevista" In: Inimigo Rumor. Rio de Janeiro, Lisboa: Cotovia, 7 Letras, Angelus Novus, n 11, p. 190-197, $2^{\circ}$ semestre de 2001. . "Nota inútil" in FORTE, António José. Uma faca nos dentes. Lisboa:

Parceria A. M. Pereira, 2003.

- _. Os passos em volta. São Paulo: Azougue Editorial, 2005

- _ _ Photomaton \& Vox. Lisboa: Assírio \& Alvim, 2006.

- _ _ Poemas completos. Porto: Porto Editora, 2014.

- __ _ . "Relance sobre Afonso Duarte". In: Folhas de Poesia Lisboa: no 3, p. 4-6, setembro de 1958.

. "Relance sobre a poesia de Edmundo de Bettencourt" in Poemas de

Edmundo de Bettencourt. Lisboa: Assírio \& Alvim, 1999.

- _ _ Servidões. Lisboa: Assírio \& Alvim, 2013.

- _ _ . Vocação Animal, "Coleção Cadernos de Poesia". Lisboa: Publicações Dom Quixote, 1971.

- MARTINS, Floriano, SEIXAS, Cruzeiro. "FLORIANO MARTINS | Cruzeiro Seixas

- O horizonte sob desmedida" In: Agulha Revista de Cultura, sábado, 19 de setembro de 2015 http://arcagulharevistadecultura.blogspot.com.br/2015/09/floriano-martinscruzeiro-seixas-o.html.

- SAlomão. Cântico dos cânticos. (Trad. Augusto Frederico Schmidt). Rio de Janeiro: Hedra, 1938. $-$ . Cântico dos cânticos” In: Éden: um tríptico bíblico.(Trad. Haroldo de Campos). São Paulo: Perspectiva, 2004. 
. Cântico dos cânticos. (Trad. Antonio Medina Rodrigues) São Paulo:

Hedra, 2008. . "Cântico dos cânticos" In: HERBERTO HELDER. O bebedor noturno: poemas mudados para o português. Lisboa: Assírio \& Alvim, 2010.

- SEIXAS, Cruzeiro. "Carta inútil e comunicação quase automática" in A IDEIA: revista de cultura libertária, $\mathrm{n}^{\mathrm{o}}$ 71/72, Évora: novembro de 2013, consultado virtualmente em http://colectivolibertarioevora.files.wordpress.com/2013/12/a-ideia71-72.pdf.

. "Entrevista" In: Revista ENTRE, Lisboa: no 5, p.56-71, inverno de 2014

- _ _ Eu falo em chamas. Guimarães: Galeria Gilde, 1986.

- _ Homenagem à realidade. São Paulo: Escrituras, 2005.

- __ . Obra Poética (vol. I). Quasi Edições: Vila Nova de Famalicão, 2002.

$-$ . Obra Poética (vol. II). Quasi Edições: Vila Nova de Famalicão, 2003 . Obra Poética (vol. III). Quasi Edições: Vila Nova de Famalicão, 2004 . Viagem sem regresso. Lisboa: Edição Tiragem Limitada, 2001. 


\subsection{Bibliografia poético-literária (geral)}

- BRANDÃO, Fiama Hasse Pais. Obra breve: poesia reunida. Lisboa: Assírio \& Alvim, 2006.

- DE LA CRUZ, San Juan. Poesía Completa y comentários en prosa. Barcelona: Editorial Planeta, 1989.

- FARIA, Daniel. Poesia. Assírio \& Alvim, 2012.

- JARRY, Alfred. O amor em visitas. Lisboa: \& etc, 2003.

- JORGE, Luiza Neto. Poesia (1960-1989). Lisboa: Assírio \& Alvim, 2001.

- LAUTRÉAMONT. Cantos de Maldoror. São Paulo: Iluminuras, 2005.

- LIMA, Sergio Claudio de Fransceschi. O corpo significa. São Paulo: EDART, 1976.

- NAVA, Luís Miguel. Poesia completa (1979-1994). Lisboa: Publicações Dom Quixote, 2002.

- NEGREIROS, Almada. A invenção do dia claro. Lisboa: Assírio \& Alvim, 2005, p. 20 .

- PACHECO, Luiz \& COELHO, Teresa Dias. Comunidade. Lisboa: Contexto Editora, 1980.

. O espelho libertino. São Paulo: Escrituras, 2007

- RIMBAUD, Arthur. Euvres completes. Paris: Édition Le Livre de poche, 1999.

- SAMPAIO, Ernesto. O sal vertido. Lisboa: Hiena Editora, 1988.

- TAVARES, Gonçalo M. Atlas do corpo e da imaginação. Alfragide: Editorial Caminho, 2013. 


\subsection{Bibliografia teórica}

- BATAILLE, Georges. O erotismo. São Paulo: L\&PM, 1987.

- _. As lágrimas de Eros. Lisboa: Sistema Solar, 2012.

- BECHARA, Evanildo. Moderna gramática portuguesa. Rio de Janeiro: Editora Lucerna, Nova Fronteira, 2006.

- BLANCHOT, Maurice. A parte do fogo. Rio de Janeiro: Rocco, 2011.

- BUTLER, Judith. Bodies that matter: On the discursive limits of sex. New York: Routledge, 1993.

- CUNHA, Celso e CINTRA, Lindley. Nova gramática do português contemporâneo. Rio de Janeiro: Nova Fronteira, 2001.

- DELEUZE, Gilles \& GATTARI, Félix. Mil platôs (vol.3). São Paulo: Editora 34, 2012.

- DERRIDA, Jaques. A farmácia de Platão. São Paulo: Iluminuras, 2005.

- DESCARTES, René. Discurso sobre o método. São Paulo: Hemus Editora, s/d. $-$ . Meditações metafísicas (Trad. Maria Ermantina Galvão). São Paulo:

Martins Fontes, 2005.

-_ . Princípios da Filosofia. Lisboa: Edições 70, 1997.

- FAUSTO-STERLING, Anne. Sexing the body. New York: Basic Books, 2000.

- FOUCAULT, Michel. O corpo utópico, as heterotopias. São Paulo: n-1 Edições, 2013.

- FREUD, S. Obras Completas volume 12: Introdução ao narcisismo, ensaios de metapsicologia e outros textos (1914-1916). Tradução: Paulo César de Souza. São Paulo: Companhia da Letras, 2010.

- _ _Os estímulos e as Fontes dos Sonhos" In: A interpretação dos sonhos. Rio de Janeiro: Imago Editora, 2001. . "O inconsciente" In: Escritos sobre a Psicologia do Inconsciente.

Rio de Janeiro: Imago, 2006.

- GREENBERG, Clement. "Abstrato, figurativo e assim por diante” In: Arte e cultura. São Paulo: Cosac Naify, 2013.

- GREIMAS, A. J. "Por uma teoria do discurso poético" In: Ensaios de semiótica poética. São Paulo: Cultrix, 1975.

- LEIRIS, Michel. Espelho da tauromaquia. São Paulo: Cosac \& Naify, 2001.

- MAINGUENEAU, Dominique. O contexto da obra literária. São Paulo: Martins 
Fontes, 2001.

- MELEAU-PONTY, Maurice. "A dúvida de Cézanne" In: Coleção "Os Pensadores". São Paulo: Abril Cultural, 1980.

- _ _ A natureza. São Paulo: Martins fontes, 2006.

- _ C Conversas - 1948. São Paulo: Martins Fontes, 2009.

- _ _ Fenomenologia da percepção. São Paulo: Martins Fontes, 1996.

- _ . O visível e o invisível. São Paulo: Perspectiva, 2000.

- NANCY, Jean-Luc. À escuta. Belo Horizonte: Edições Chão da Feira, 2014.

$-$ . Corpus. Lisboa: Vega, 2000.

- PAZ, Octavio. Os filhos do barro. Rio de Janeiro: Nova Fronteira, 1984.

- _ _ A dupla chama: amor e erotismo. São Paulo: Siciliano, 1994.

- RASTIER, François "Sistemática das isotopias" In: Ensaios de semiótica poética. São Paulo: Cultrix, 1975.

- REY-DEBOVE, Josette. Le metalangage. Montréal: Le Robert, 1986.

- RICOEUR, Paul. A metáfora viva. São Paulo: Edições Loyola, 2005.

- SARDUY, Severo. Escrito sobre um corpo. São Paulo, Editora perspectiva, 1979.

- ZUMTHOR, Paul. Escrita e nomadismo. São Paulo: Ateliê Editorial, 2005. Performance, recepção, leitura. São Paulo: Cosac Naify, 2007. 


\subsection{Bibliografia crítica}

- CAMPOS, Haroldo de. Metalinguagem \& outras metas. São Paulo: Perspectiva, 1992.

- CORREIA, Natália. O surrealismo na poesia portuguesa. Lisboa: Frenesi, 2002.

- CUADRADO, Perfecto. A única real tradição viva. Lisboa: Assírio \& Alvim, 1998.

- DA SILVA, Maria Isabel. "A metalinguagem na crônica de Drummond" In: Textualidade e discursividade (GUIMARÃES, Elisa, org.). São Paulo: Universidade Presbiteriana Mackenzie, 2010.

- DAL FARRA, Maria Lúcia. A alquimia da linguagem: leitura da cosmogonia poética de Herberto Helder. Lisboa: Imprensa Nacional-Casa da Moeda, 1986.

- EIRAS, Pedro. “A pedra na cabeça. Herberto Helder, René Descartes, uma questão de loucura”. In: Textos pretextos, número 17, outono/inverno 2012, p.20-29.

- FRANÇA, Maria Inês. "Fascinação: o olhar e o objeto no surrealismo e na psicanálise" In: O Surrealismo. (Org. GUINSBURG, J. E LEIRNER, Sheila). São Paulo: Editora Perspectiva, 2008.

- FRANCO, António Cândido. Mário Cesariny: Cartas para a casa de Pascoaes. Vila Nova de Famalicão: Documenta, Fundação çupertino de Miranda, 2012. - Teixeira de Pacoaes nas palavras do surrealismo em português.

Editora Licorne, 2010.

- FREITAS, Manuel de. Pedacinhos de ossos. Lisboa: Averno, 2012. $-$ . Uma espécie de crime: "Apresentação do rosto" de Herberto Helder.

Lisboa: \& etc., 2001.

- GOLDBERG, RoseLee. A arte da performance: Do Futurismo ao presente. São Paulo: Martins Fontes, 2006.

- GUEDES, Maria Estela. "Dois textos" in IDEIA: revista de cultura libertária, no 71/72, Évora: novembro de 2013, p. 78-81, consultado virtualmente em http://colectivolibertarioevora.files.wordpress.com/2013/12/a-ideia-71-72.pdf.

- _ _ A obra a rubro de Herberto Helder. São Paulo, Editora Escrituras, 2010.

- _. Herberto Helder, poeta obscuro. Lisboa: Moraes Editores, 1979.

- GUSMÃO, Manuel. "Entre nós e as palavras (Mário Cesariny)” In: Tatuagem e palimpsesto. Lisboa: Assírio \& Alvim, 2010. . "Herberto Helder, 'a estrela plenária;" In: Tatuagem e palimpsesto. 
Lisboa: Assírio \& Alvim, 2010. "Leiam Herberto Helder Ou o Poema Contínuo" In: Tatuagem e palimpsesto. Lisboa: Assírio \& Alvim, 2010.

- JOAQUIM, Ana Cristina. "Entrevista com Artur Cruzeiro Seixas". In: Revista Desassossego, Universidade de São Paulo, nº13, p.136-141, jun./2015. . "O escritor no espaço da obra: o rosto caligrafado - uma leitura de Apresentação do Rosto, de Herberto Helder" In: Revista do CESP, Belo Horizonte, v. 34, n. 52, p.77-99, 2014.

- KIFFER, Ana. Antonin Artaud, uma poética do pensamento. A Coruña: VEGAP, 2003.

- LETRIA, José Jorge. Cruzeiros Seixas: A liberdade livre. Diálogo com José Jorge Letria. Lisboa: Guerra \& Paz, 2014.

- LOPES, Silvina Rodrigues. A inocência do devir: ensaio a partir da obra de Herberto Helder. Viseu: Edições Vendaval, 2003.

- LÖWY, Michel. A estrela da manhã: surrealismo e marxismo. Rio de Janeiro, Civilização Brasileira, 2002.

- MACEDO, Helder. "A utopia da negação", Arte \& Utopia (Ed Margarida Acciaiuoli, Ana Duarte Rodrigues, Maria João Castro, Paula André, Paulo Simões Rodrigues) CHAIA; DINÂMICA'CET-IUL; FCSH, Lisboa, 2013 (pp. 237-244).

- MÃE, Valter Hugo. "Cruzeiro Seixas”. Jornal de Letras e Artes, 19 de fevereiro de 2014.

- MAFFEI, Luis. Do mundo de Herberto Helder. Tese de doutoramento em Letras Vernáculas. Rio de Janeiro, Faculdade de Letras/UFRJ, 2007.

- ___ _ _Os gregos antigos não escreviam necrológios” In: Soldado aos laços das constelações. São Paulo: Lumme Editor, 2011.

- MACEDO, Helder. "A utopia da negação", Arte \& Utopia (Ed Margarida Acciaiuoli, Ana Duarte Rodrigues, Maria João Castro, Paula André, Paulo Simões Rodrigues) CHAIA; DINÂMICA'CET-IUL; FCSH, Lisboa, 2013 (pp. 237-244).

- MARINHO, Maria de Fátima. Herberto Helder: a obra e o homem. Lisboa: Editora Arcádia, 1982. O surrealismo em Portugal. Lisboa: Imprensa Nacional/Casa da Moeda, 1987.

- MARTELO, Rosa Maria. "Assassinato e assinatura" In: A forma informe: leituras de poesia. Lisboa: Assírio \& Alvim, 2010. 

"Herberto Helder, o nome da obra" In: José Quaresma (coord.). Gravura, Instalação e Poesia. A Alegria de um encontro. Printmaking, Installation and Poetry. The Joy of a Reunion. Lisboa: CIEBA-FBAUL, 2012, pp. 44-48. (consultado em: https://www.academia.edu/12440862/Herberto_Helder_o_nome_da_obra) . "O corpo e o corpus: Eugénio de Andrade vs. Pessoa (e outros caminhos" In: Em parte incerta, estudos de poesia portuguesa moderna $e$ contemporânea. Porto: Campo das Letras, 2004.

- MARTINHO, Fernando J. B. Tendências dominantes da poesia portuguesa da década de 50. Lisboa: Edições Colibri, 2013 (2a edição).

- MONTEIRO, Manuel Hermínio. “Surrealismo: do 'cadáver-esquisito' ao gato resplendente andando pela noite" In: A Phala, um século de poesia (edição especial). Lisboa: Assírio \& Alvim, 1988.

- MORAES, Eliane Robert. O corpo impossível. São Paulo: Iluminuras, 2002.

- OLIVEIRA, Fernando Matos. "Introdução" In: PEDRO, António. Antologia Poética (introdução seleção e notas de Fernando Matos Oliveira. Braga, Coimbra: Ângelus Novus, 1998.

- PEREIRA, José Pacheco. Biblioteca e arquivo:

http://ephemerajpp.com/2012/01/25/censura-relatorio-no-8243-22-de-julho-de-1968relativo-a-apresentacao-do-rosto-de-herberto-helder-censorship-report-no-8243-july22-1968-on-apresentacao-do-rosto-of-herberto-helder/.

- PIMENTA, Alberto. A magia que tira os pecados do mundo. Lisboa: Cotovia, 1995. O silêncio dos poetas. Lisboa: Edições Cotovia, 2003.

- PIMENTEL, Diana. Ler a voz, ver o rosto: uma polaroide de Herberto Helder. Porto: Campo das Letras, s/d.

- POMA, Paola. "Herberto Helder: o antropófago da linguagem" in Anais do XII $\begin{array}{llll}\text { Congresso Internacional 2009, } & \text { Abraplip, }\end{array}$ (http://www.abraplip.org/anais2009/documentos/mesas_tematicas/paola_poma.pdf).

- RUBIM, Gustavo. Experiência da alucinação. Camilo Pessanha e a questão da poesia. Lisboa: Editorial Caminho, 1993.

. "Maternidade e truculência" In: A arte de sublinhar. Coimbra:

Angelus Novus, 2003.

- SCATOLIN, Adriano. "Introdução" In: SALOMÃO. Cântico dos cânticos. São Paulo: Hedra, 2008.

- SILVA. Franklin Leopoldo e. Descartes: a metafísica da modernidade. São Paulo: 
Editora Moderna, 1993.

- SILVEIRA, Jorge Fernandes da. "Acolher na boca, depois no chão dos olhos: o poema (Ou o dia em que Herberto Helder de uma queda foi ao chão da mão de Fiama Hasse Pais Brandão)’'In: Diacrítica. Braga: Universidade do Minho, n²3/3, pp. 83$100,2009$.

. "O Amor Cru: Herberto Helder e Camões ou As Duas Mães" In:

Verso com verso. Coimbra: Angelus Novus, 2003.

- SIMAS, Monica. "Surrealismo e Abjeccionismo: dois movimentos controversos". Anais do XX Encontro de Professores Brasileiros de literatura Portuguesa - No Limite dos Sentidos. Rio de Janeiro: L. Christianol/Newbooks Editoração Eletrônica, 2005. CD-ROM.

- TCHEN, Adelaide Ginga. A aventura surrealista. Lisboa: Edições Colibri, 2001.

- TORRANO, Jaa. O pensamento mítico no horizonte de Platão. São Paulo: Annablume Clássica, 2013.

- VASONCELOS, Maurício Salles. Espiral terra-poéticas contemporâneas de língua portuguesa. Tese de livre-docência. São Paulo: FFLCH-USP, 2010.

- __ Exterior. Noite - Filosofia/Literatura. Bauru: Lumme Editor, 2015.

- _. Jean-Luc Godard: história(s) da literatura. Belo Horizonte:

Relicário Edições, 2015.

- VASCONCELOS, Ricardo. Campo de relâmpagos: leituras do excesso na poesia de Luís Miguel Nava. Lisboa: Assírio \& Alvim, 2009.

-WILLER, Claudio. "André Breton e Antonin Artaud" http://claudiowiller.wordpress.com/2012/02/03/andre-breton-e-antonin-artaud/ 


\section{Anexos}


ANEXO A - Capa do Catálogo da Exposição do Grupo Surrealista de Lisboa

\section{GRUPO SURRELLISTI DE LISBOA}

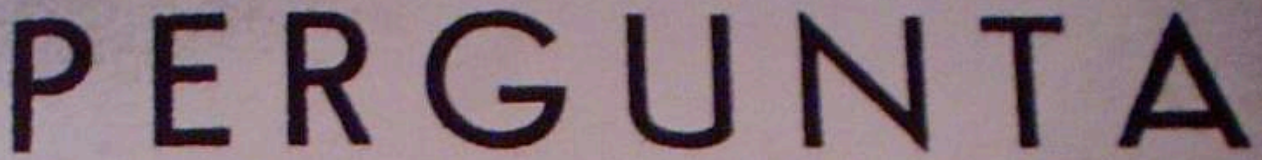

\section{DEPOIS DE 22 ANOS DE}
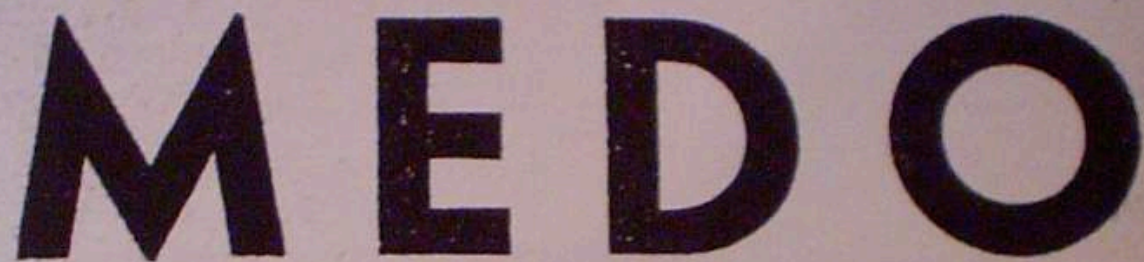

AINDA SEREMOS CAPAZES DE UM ACTO DE

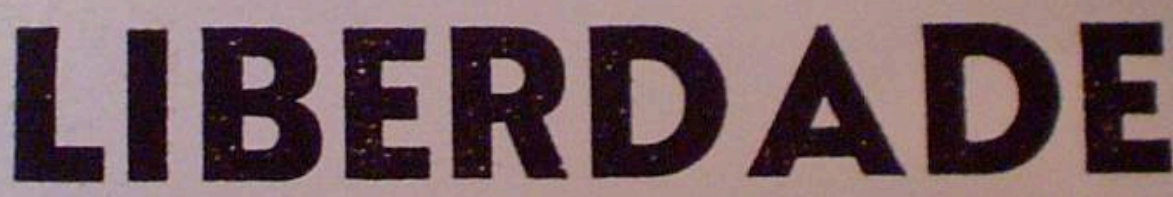

É ABSOLUTAMENTE INDISPENSÁVEL

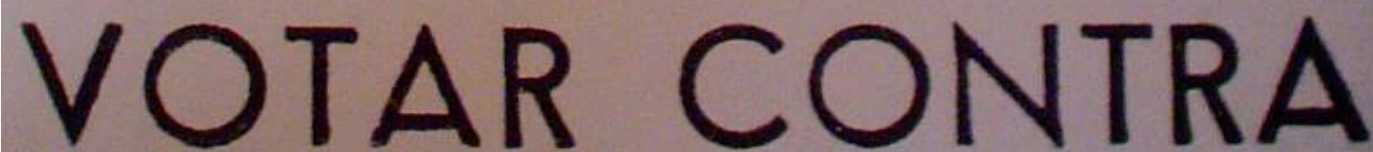

O PSCISMO 


\title{
ANEXO B - Na 1ª Exposição de Cruzeiro Seixas em África
}

\author{
Do Catálogo
}

Je retrouverais le secret des grandes comunications et dês grandes combustions. Je dirais orage. Je dirais fleuve. Je dirais tornade. Je dirais feuille. Je dirais arbre.

Aimé Cesaire

La poésie doit être faite par tous, non par un.

Conde de Lautréamont

Quelle vanité que la peinture qui attire l'admiration pour la ressemblance des choses dont on n'admire pas les originaux.

Pascal

Restitue a toutes choses les couleurs perdues du temps dês anciens soleils.

André Breton

Si tu n'espéres pas tu ne recontreras pas l'inespére qui est inesplorable dans l'impossible.

Heraclite de Efeso

Je suis un monstre apartenant à une realité qui n'existe as encore

Henry Miller

O destino da razão é ver que há muitas coisas que vão mais além do que ela.

Pascal

Surrealismo: automatismo psíquico puro por meio do qual se trata verbalmente, por escrito, ou de qualquer outra forma, o funcionamento real do pensamento, com ausência de todo o controlo da razão, e de toda a preocupação estética ou moral.

Manifesto do Surrealismo I929 
Entre os nossos bens os maiores são os que nos vêm por intermédio do delírio.

Platão

Queria de ti um país de bondade e de bruma

Queria de ti o mar de uma rosa de espuma.

Mário Cesariny

La poesie ne rythmerà plus l'action: ellc será en avant.

Rimbaud

Tudo induz a acreditar que existe certo ponto do espírito em que a morte, o real e o imaginário, o passado e o futuro, o comunicável e o incomunicável, o alto e o baixo cessem de ser percebidos contraditoriamente. Em vão se deve procurar outro móbil à actividade surrealista, que a esperança de determinar esse ponto.

André Breton - "Dictionaire du Surrealisme"

(In: CESARINY, Mário. A intervenção surrealista. Lisboa: Assírio \& Alvim, 1997, pp. $186,187$. 


\section{ANEXO C - Na 2a exposição de Cruzeiro Seixas Em África (15-24 - Jan. 57)}

\section{Do Catálogo}

Dois pilares, que não era difícil e ainda menos impossível tomar por dois imbondeiros, distinguiam-se na encosta, maiores que dois alfinetes. Com efeito, eram duas torres enormes. E, ainda que dois imbondeiros, à primeira vista, não se assemelhem a dois alfinetes, nem mesmo a duas torres, entretanto, e empregando habilmente os cordelinhos da paciência, pode afirmar-se sem receio de errar (porque se esta afirmação fosse acompanhada de uma única parcela de receio deixaria de ser uma afirmação; ainda que um mesmo nome exprima estes dois fenómenos da alma que apresentam caracteres marcados para não serem confundidos ligeiramente) que um imbondeiro não difere tão grandemente de um pilar, que seja proibida a comparação entre estas formas arquitetônicas... ou geométricas... ou umas e outras... ou nem umas nem outras... ou então formas elevadas e maciças. Acabo de encontrar, não tenho a pretensão de dizer o contrário, os epítetos próprios aos substantivos pilar e imbondeiro: que saibam bem que não é sem uma alegria misturada de orgulho que faço a observação aos que, depois de terem levantado as pálpebras, tomaram a muito louvável resolução de percorrer estas páginas, enquanto a vela arde, se é noite, enquanto o sol ilumina, se é dia. E, ainda que uma potência superior ordenasse, nos termos mais claramente precisos, que lançássemos aos abismos do acaso a comparação judiciosa que cada um certamente pôde saborear na impunidade, mesmo então, e sobretudo então, que não se perca de vista este axioma principal, os hábitos contraídos ao longo dos anos, os livros, o contacto com os nossos semelhantes, e o carácter inerente a cada um, que se desenvolve numa eflorescência rápida, imporiam ao espírito humano o irreparável estigma da reincidência no emprego criminoso (criminoso, momentaneamente, e espontaneamente, no ponto de vista da potência superior) de uma figura de retórica que vários desprezaram, mas que muitos incensam. Se o leitor acha esta frase muito longa, queira aceitar as minhas desculpas; mas não espere baixezas da minha parte. Posso confessar as minhas faltas; mas não, torná-las mais graves pela minha cobardia. Os meus raciocínios chocar-se-ão algumas vezes com os guizos da loucura e a aparência séria do que não do que não é em suma senão grotesco, ainda que, sendo alguns filósofos, seja muito difícil distinguir o bufão do melancólico, sendo 
a vida em si mesma um drama cómico ou uma comédia dramática; entretanto, é permitido a cada um matar moscas e até rinocerontes, a fim de repousar de tempos a tempos de um trabalho muito árduo. Para matar moscas, eis aqui a maneira mais expedita, ainda que não a melhor: esmagam-se entre os dois primeiros dedos da mão. A maior parte dos escritores que tratam este assunto calculou, com muita verossimilhança, que é preferível, em muitos casos, cortar-lhes a cabeça. Se alguém me censura por falar de alfinetes como de um assunto radicalmente frívolo, que repare sem ideias preconcebidas que os maiores efeitos são muitas vezes produzidos pelas coisas mais pequenas. E para não me afastar excessivamente do quadro desta folha de papel, não se vê que o laborioso pedaço de literatura que estou a compor, desde o inicio desta estrofe, seria talvez menos apreciado, se tivesse o seu ponto de apoio numa questão espinhosa de química ou de patologia interna? De resto, todos os gostos estão dentro da natureza; e, quando no inicio comparei os pilares aos alfinetes, com tanta justeza (é certo que não julgava que algum dia viriam censurar-mo), baseei-me nas leias da óptica, que estabeleceram que, quanto mais o raio visual se afasta do objecto, mais a imagem se reflecte diminuída na retina.

É assim que aquilo que a inclinação do nosso espírito para a farsa toma por urna miserável pilhéria é, na maior parte das vezes, no pensamento do autor, uma verdade importante, proclamada com majestade. Oh! esse filósofo insensato que desatou a rir vendo um burro comer um figo! Não invento nada: os livros antigos contam, com mais amplo detalhe, esta voluntária e vergonhosa falta de nobreza humana. Eu, não sei rir. Nunca pude rir, ainda que algumas vezes tenha tentado fazê-lo. É muito difícil aprender a rir. Ou antes, creio que um sentimento de repugnância por essa monstruosidade forma uma marca essencial do meu carácter. Pois bem, eu fui testemunha de qualquer coisa mais forte: vi um figo comer um burro! E, contudo, não me ri; francamente, nenhuma parte bucal se moveu. A necessidade de chorar apoderouse de mim tão fortemente que os meus olhos deixaram cair uma lágrima. "Natureza! Natureza!", gritei, soluçando, “o gavião desfaz o pardal, o figo come o burro e a tênia devora o homem!" Sem tomar resolução de ir mais longe, pergunto a mim mesmo se falei da maneira como se matam as moscas. Falei, não é verdade? Mas não é menos certo que não cheguei a falar da destruição dos rinocerontes! Se alguns amigos pretendem o contrario, não os escutarei, e lembrar-me-ei que o louvor e a lisonja são duas pedras na estrada. Entretanto, afim de contentar tanto quanto possível a minha consciência, não posso impedir-me de fazer notar que uma dissertação sobre o 
rinoceronte me arrastaria para além das fronteiras da paciência e do sangue frio e, pelo seu lado, desencorajaria provavelmente (tenhamos, mesmo, a ousadia de dizer certamente) as gerações presentes. Não ter falado do rinoceronte depois da mosca! Ao menos, para escusa passável, deveria mencionar com prontidão (e não o fiz) esta omissão não premeditada, que não espantará os que estudaram a fundo as contradições reais e inexplicáveis que habitam os lóbulos do cérebro humano. Nada é indigno para um inteligência grande e simples: o menor fenômeno da natureza, se há mistério nele, tornar-se-á, para o sábio, inesgotável matéria dc reflexão. Se alguém vê um burro comer um figo ou um figo comer um burro (estas duas circunstâncias não se repetem muitas vezes, a menos que seja na poesia), ficai certos de que, após ter reflectido dois a três minutos, para saber que conduta adoptar, abandonará o atalho da virtude e por-se-á a rir como um galo! Todavia, não está exactamente provado que os galos abram expressamente o bico para imitar o homem a fazer um esgar atormentado. Chamo esgar nos pássaros ao que tem o mesmo nome na humanidade! O galo não abandona a sua natureza, menos por incapacidade do que por orgulho. Ensinai-os a ler, e revoltarse-ão. Não é um papagaio para extasiar-se da mesma maneira ante a sua fraqueza, ignorante e imperdoável! Oh, aviltamento execrável! Como o homem se parece com urna cabra, quando ri! A calma da fronte desaparece para dar lugar a dois enormes olhos de peixe que (não é isto deplorável?) que... que... começam a brilhar como faróis! Muitas vezes, acontecer-me-á considerar com solenidade as proposições mais chorraqueiras... Não acho que isso seja um motivo peremptoriamente suficiente para alargar a boca! Não posso impedir-me de rir, responder-me-eis; aceito essa explicação absurda, mas, então, que seja um riso melancólico. Ride, mas chorai ao mesmo tempo. Se é ainda impossível, urinai; mas advirto que um liquido qualquer é aqui necessário, para atenuar a secura que carrega nos flancos, o riso, de feições fendidas atrás.

Quanto a mim, não me deixarei perturbar pelos cacarejos ridículos e pelos bramidos originais daqueles que encontram sempre qualquer coisa a redizer de um carácter que não se assemelha ao seu, por ser uma das inumeráveis modificações intelectuais que Deus, sem sair do tipo primordial, criou para governar as estruturas ósseas. Até aos nossos dias, a poesia seguiu uma rota falsa; elevando-se até ao céu ou abatendo-se até à terra, desconheceu os princípios da sua existência, e foi, não sem razão, constantemente achincalhada pelas pessoas honestas. Não foi modesta... a qualidade mais bela que deve existir num ser imperfeito; eu, quero mostrar as minhas qualidades; mas, não sou suficientemente hipócrita para esconder os meus vícios! O 
riso, o mal, o orgulho, a loucura aparecerão, um de cada vez, entre a sensibilidade e o amor da justiça, e servirão de exemplo à estupefacção humana: todos se poderão aí reconhecer, não como deviam ser, mas tal como são. E, talvez que este simples ideal, concebido pela minha imaginação, ultrapasse, entretanto, tudo o que a poesia encontrou até aqui de mais grandioso e mais sagrado. Porque se deixo os meus vícios transparecer nestas páginas, acreditar-se-á melhor nas virtudes que faço resplender e a que colocarei tão alta auréola que os maiores génios do futuro testemunharão um sincero reconhecimento. Por conseguinte, a hipocrisia será pesadamente expulsa da minha habitação. Existirá, nos meus cantos, uma prova majestosa de potência, para desprezar assim as opiniões recebidas. Eles cantam por si, e não para os seus semelhantes. Não colocam a medida da sua inspiração na balança humana. Livre como a tempestade, veio encalhar um dia nas praias terríveis da vontade! Nada receia, a não ser a si mesmo! Nestes combates sobrenaturais, atacará o homem e o Criador, com vantagem, como quando o espadarte mergulha a sua espada no ventre da baleia: que seja maldito, pelos seus filhos e pela minha mão descarnada, aquele que persiste em não compreender os cangurus implacáveis do riso e os piolhos audaciosos da caricatura!... Duas torres enormes podiam ser distinguidas na encosta; disse-o de início. Multiplicando-as por dois, o produto dá quatro... mas não se via bem a necessidade desta operação aritmética. Continuei o meu caminho, com febre no rosto, e gritava-me sem cessar: "Não... não... não vejo bem a necessidade desta operação aritmética!" Tinha-me apercebido de um estrépito de cadeias e de gemidos dolorosos. Que ninguém julgue possível, quando passar neste lugar, multiplicar as torres por dois a fim de que o produto seja quatro.

Alguns suspeitam que eu amo a humanidade como se fosse a sua própria mãe e a tivesse trazido nove meses nos meus flancos perfumados; esta a razão por que deixei de passar na encosta onde se erguem as duas unidades do multiplicando!

Isidore Ducasse, Conde de Lautréamont

"Chants de Maldoror"

(In: CESARINY, Mário. A intervenção surrealista. Lisboa: Assírio \& Alvim, 1997, p. 222-227) 


\section{ANEXO D - NOTA INÚTIL}

A poesia de Antonio José Forte não é um lugar-comum surrealista, como alguma da por cá exercida entre o fim da década de 50 e o começo da seguinte, e também da muita que se exerce agora sub-repticiamente. Evaporou-se, toda ela, a outra, e a sub-reptícia actual, essa a cada instante se evapora ainda em estado morno de caligrafia.

Recordo a vaga estilística levantada por Cesariny entre os jovens da altura; Cesariny reaparece entretanto desembaraçado à volta, indemne: o rosto acabará por assemelhar-se ao retrato rápido e amargo nos poemas, autêntico, com uma luz. Mas prevejo que a sua palavra vai de novo lavrar recobrada no formigueiro; um grande poeta nunca se furta à degradação interposta.

A natureza primeira desses lugares-comuns é distintamente a indistinção. A força peremptória capaz de construir um universo de mitos e símbolos particulares que uma linguagem identificável sustenta, só a mostra a singularidade; quanto mais contrabandeada, melhor se verá nela, na singularidade, a sua força natural. E percebese, pelo nexo entre a superfície das leituras e esse afã adúltero, que alguns poetas se tenham queixado do equivoco de reputações e ensinos. Eu acho que sim, é um equívoco. Eles pediram às vezes, como benevolência e pausa destas coisas, a misericórdia da obscuridade. Pois todas as pequenas festas e celebrações, embora pequenas ou por serem pequenas e pelos resultados pequenos, introduzem a desavença entre aquilo que é e aquilo que não pode ser e todos parece desejarem que seja.

A voz de Force não é plural, não é directa ou sinuosamente derivada, não é devedora. Como toda a poesia, a verdadeira, possui apenas a sua tradição, no caso da tradição romântica no menos estrito e mais expansivo e qualificado registo, uma tradição próximo de nós esclarecida pelo surrealismo, imemorial, dinâmica, abrindo para trás e para diante, única maneira de entender-se uma tradição. Não se trata de modo ou moda, forma ou fórmula, acidentalidade ou incidentalidade. O teor é o da inteligência fundamental do mundo.

Gostaria de acentuar o carácter dramático desta aventura, de condenação, de expiação social, uma aventura destinada às câmaras de gás. E nesse regime, e a propósito de Cesariny também, sublinho como aparece ilusória, contrária, a "reabilitação do real quotidiano" onde, na traça de Auden, "there is no place for us". 
não há espaço demais para ficar

$\mathrm{Ou}:$

hoje não é a mesma coisa

que um búzio para ouvir o coração

não é um dia no seu eixo

não é para pessoas

E significa que

é um dia perfeitamente para cães

Não, claro, para o cão que da pungente paródia clownesca de Dylan Thomas ao titulo joyceano valeu ao autor um esplêndido poema, Retrato do Artista em Cão Jovem, obtido na matéria mais sensivelmente vulnerável do extravio nos labirintos diários, a dor e o medo, palavra difícil, acossada até ao silêncio, arduamente dita por quem se emprestou a boca de um "povo que oculta a cabeça nas entranhas dos mortos".

Com o focinho entre dois olhos muito grandes

por trás de lágrimas maiores

este é de todos o teu melhor retrato

o de cão jovem a que só falta falar

o de cão através da cidade

Conheço várias determinações de silêncio e as deste poeta, cuja distância se estende por quase 20 anos, podem talvez achar-se no transcurso pelo horror quotidiano, pois sabe-se às vezes que a poesia é tão inviável que ninguém a empunha como uma arma, não subverte o quotidiano nem a historia. Quando e em que estilo se mantém ela como bagagem da guerra vista ou de alguma guerra provável nos acampamentos?

E já ouvi que a palavra não traduz a acção. Se a não traduz, como pode superlativamente "ser" a acção? Rimbaud despede-se, e sobretudo toda a grande hierarquia da palavra geradora desde - que sei eu? - a Kabbalah às, remontando, mais 
eminentes cosmogonias. Resta o jogo?

Afinal o poeta intenta uma forma onde a história se consubstancia e se transmude e miticamente ultrapasse os poderes dispersivos. Não sendo a história nem efectivando nela a revolução, a poesia refere-a no âmbito dos símbolos, transfere-lhe o significado para esse âmbito porventura incontinente, permanente, desconto feito às morfologias.

Para quem se não satisfaça no ludismo nem esgote o empenho do verbo nas gramáticas, e nenhuma alta poesia nelas se esgota, o lugar de passagem e o lugar hipotético de chegada serão sempre dramáticos. Toda a poesia é insolúvel. Não lhe falta ou sobra o mundo, nem é a contradição do mundo aquilo que a embaraça. Trata-se do vácuo criado pela historia no seio do mito. O silêncio não traduz apenas a renúncia, mas a ruptura entre o mundo e a linguagem. O que se não exprime fatalmente pela ausência do dizer. Não será essa mesmo uma condição do dizer? O paradoxo reside nessa ambição unitária no meio da descontinuidade e fragmentarismo de tudo: o mito, a história, o eu.

Já se indicou que o homem barroco se mobiliza no pensamento da morte; o espaço mortal em torno, enche-o ele com a teoria das formas, a veemência invasora; ele povoa o vazio, a pergunta, com a multiplicação de respostas que são, elas próprias, novas perguntas. Circunvoluciona.

Note-se que pelos processos e concreções, quer dizer: pelo método de criação de formas, esta poesia é barroca, fragmentária, objectiva. "O homem barroco acumula fragmentos", diz Walter Benjamin, porque é precária a sua noção do tempo, ao invés da noção do espaço, imperativa, essa. A continuidade do eu fez-se por inquilinato espacial, por socorro objectivo. Como muita poesia surrealista ou afim, a de Forte molda-se num corpus de fragmentos soldados por pontos magnéticos de analogia imaginística ou verbal, por enlaces rítmicos: uma colagem orgânica de fragmentos. $\mathrm{O}$ continuum, sempre perfeito denota a ágil intuição dos recursos de escrita, uma oficina atenta. Quando comparece, o tempo é condição ou só tradução, tradução obliterada, do espaço. E por virtude das figurações espaciais, directas ou desviadas, desenvolve-se visualmente. Os materiais e a norma do seu uso dispõem de textura e espessura objectivas.

Fala-se em oficina, em cuidado artesanal, a respeito de um poeta de linhagem surrealista. Seria lícito distinguir várias noções, por exemplo: as de "escrita automática" e "inspiração", esse terrífico júbilo criador, não apenas inventiva mas 
obscura fluência conjugada do nome, da realidade percebida e das mais completas possibilidades do espírito, isso que tão abalada e minuciosamente foi descrito, até nos efeitos físicos, por Nietzsche - parente profana de uma eventualidade do prodígio: $\mathrm{o}$ homem transforma-se numa voz proferidora, ao indecifrável e implacável serviço das potências.

A inspiração deriva de uma apaixonada deferência pela realidade. Não se deve confundi-la com o automatismo psíquico, expresso pela escrita automática, que os surrealistas definiram como “dictée de la pensée (...), en l'absence de tout contrôle exercé par la raison, en dehors de toute préocupation esthétique (...)”. A feliz infidelidade de alguns surrealistas, declarada e documentada, permitiu-lhes os poemas melhores. O estado de poesia, se assim se quiser designar, pode ser especificado pela circunstância de consciência. Deve tudo ser posto a favor desta circunstância de consciência, todos os dons e poderes pessoais, arrebatamento, disciplina, impulso, astúcia, qualidades maiores e menores do espírito.

Coloco a questão em termos mais tranquilos recorrendo a Mandelstam, cujo intuito era tornar consciente, e portanto dominá-lo e assegurá-lo, o fluxo interior que conduz ao poema, estratégia afinal dessa deferência, dessa ordem de atenção que pertence ao domínio inspirado.

Não festejo a oficinalidade - vejam-se os fictícios e pacíficos objectos de exposição por aí, não apenas na poesia portuguesa mas em toda a parte; não exalto a escrita automática - já se evidenciou quanto ela convoca, e tantas vezes só isso, desalinhadas reminiscências literárias; mas glorifico a inspiração se consegue apoiar-se na regra dos seus próprios vocabulários. E nisto,a regra dos vocabulários, não se alude a qualquer racionalidade ingénua, qualquer anuência para fora, que tornem tudo servido fácil. São os vocabulários próprios, os secretos, os de inspiração intransferida.

É legível nos poemas de Forte uma carga de persuasão que vem, imediata, do abrupto manejo da imagem e da metáfora funcionando como sínteses perceptivas; daí sobretudo a sua eficácia, o fascínio. O tributo ao surrealismo - pauta imaginística, sopro metafórico, erotismo mágico, visão apocalíptica do quotidiano ou fé na salvação dentro da historia através da utopia - não viola o seu universo pessoal e o esquema que o traveja. Esses aspectos conformam-se a características privadas suas.

Contraditória na fogosidade destrutiva e no empenhamento regenerador, toca esta poesia determinados limites das possibilidades do fazer-se, não do fazer-se como objecto verbal mas como projecto espiritual que se instala na história e procura 
sublevá-la, dela extraindo, pelo expediente àquilo que não encontra lugar nem tempo e que por isso já é, é sempre - a utopia, a ucronia -, extraindo assim a regra da vida, o emblema, ouro metafórico que brilharia no meio da truculência e devastação. O tema esparso mas impositivo é o paraíso do amor mágico, alcançável mitograficamente após as travessias dos infernos diários de que, por soma e suma, se tece a historia.

As razões de um silêncio são ocultas sempre e compósitas, mas talvez sejam assinaláveis, aqui, nas dificuldades de efectivar um mito tão adverso. Toda a poesia assenta na sua própria dificuldade e o êxito está, não na dissolução da dificuldade, mas em torná-la activa e frutuosamente manifesta. E porque ao poeta ameaçam a bastardia, a tentação do duplo literário, saúde-se a recusa em diluir a dificuldade fértil da poesia na faciliddae estéril da escrita (“o poema devorará o poeta para não"). O autor di-lo na medida melhor: "Há (...) gente que nunca escreveu uma linha que fez mais pela palavra que toda uma geração de escritores.” Mas foi porventura necessário escrevê-lo para ser mais verdadeiro.

Herberto Helder

(In: FORTE, António José: Uma Faca nos Dentes. Lisboa: Parceria A. M. Pereira Livraria Editora, Ltda., 2003, pp. 11-16). 


\section{ANEXO E - RELANCE SOBRE A POESIA DE EDMUNDO DE BETTENCOURT}

Algumas pessoas atentas começam agora a descobrir o sentido de determinados acontecimentos ocorridos há cinquenta anos. Certa gíria chama a isto perspectiva histórica. É bem de ver que não se pode considerar numerosa a gente que, decorridos cinquenta anos, já possui uma perspectiva histórica. Um clima espiritualmente desfavorável, empenhamentos que afastam a objectividade, sem contar que meio século pouco significa para uma correcção pedagógica da estupidez - tudo isto, digo, não tem permitido tornar-se mais geral o entendimento da lição revolucionária que nos legou a geração de Fernando Pessoa.

A ambiguidade dc uma geração é algo que nasce não dela mesma, como entidade criadora, mas da resistência oferecida pelos elementos estéticos. A decifração do um tempo, isto é, a solução da sua ambiguidade, realiza-se mercê dos elementos criativos do tempo seguinte, acção esta que é nada mais nada menos do que a consecução da perspectiva histórica. $\mathrm{O}$ comum das pessoas não possui mais do que a aceitação (induzida) das significações. Elas aceitam, por espírito de convenção, o que a história garantiu. A seu respeito se deve falar, por conseguinte, em conseguimento de uma perspectiva. A compreensão da massa é sempre formal, jamais atingindo a intimidade das forças que tornaram revolucionário certo momento.

Mas nem sempre, considerando mesmo que só as élites intelectuais participam do progresso no conhecimento e da decifração das suas cifras de base, nem sempre essas próprias élites se movem na direção propícia à captação dos valores inovados pela geração anterior.

Isto mesmo se constata através da leitura de um belo ensaio que Eduardo Lourenço publicou há dois anos, numa revista brasileira, sobre o que ele certeiramente denomina a contra-revolução da Presença. Tomando como representante português do espírito moderno europeu o grupo de Pessoa e pondo-o em jogo com a geração seguinte, essa que aparentemente se filiava no mesmo impulso inovador - Eduardo Lourenço apresenta de modo indiscutível o equívoco de uma perspectiva histórica que os presencistas supunham e afirmavam possuir. Contudo, a Presença era provinciana, académica de certa maneira, anti-revolucionária com certeza. Assim, não é difícil verificar-se que a geração posterior ao Orpheu, em vez de criar a atmosfera propícia ao desenvolvimento dos princípios revolucionários contidos nele, veio atrasar de muitos 
anos a frutificação do exemplo.

Mas nos somos um povo infeliz, já que, logo após o provincianismo presencista, surgiu o Novo Cancioneiro. Aliava este, à reacção presencista, um humanitarismo sentimental assente num complexo de culpa pequeno-burguês, que menos ainda o inclinava para a compreensão do profundo revolucionarismo orfeico. Deste modo se foi relegando para um futuro que nos deseuropeizava a recuperação de uma modernidade viva.

Como mobilizador de consciências, o surrealismo, tardiamente aparecido em Portugal, não pode solucionar o nosso atraso. À parte o valor pessoal, e até o valor da sua consciência revolucionária, os nomes de Mario Cesariny e Antonio Maria Lisboa não agem visivelmente sobre a neutra paisagem da nossa poesia. E onde isso lhes não foi possível, é a historia complexa de toda urna situação mental ainda presente. Razões terríveis deslocaram para uma acção suspeita como valor revolucionário aquelas forças pelas quais se poderia ter tornado espiritualmente europeia a nossa mentalidade.

O neo-realismo, vinculando a literatura a uma acção virtualmente transformadora, mas que os homens não souberam exercer no devido plano prático, criou apenas uma curiosa alienação (termo que lhe é excessivamente grato), um cômodo processo de fuga. Para utilizar uma expressão dos domínios da psicanálise, os neo-realistas portugueses realizaram um transfert. Transferiram para ma literatura o que deveria ter sido uma boa acção social. Creio que, assim, pacificaram a sua perturbada consciência de pequeno-burgueses e imaginaram ter reformado o gosto, a sensibilidade e a imaginação. A verdade, contudo, é que não conseguiram acordar uma consciência de classe nas camadas populares (e, se não era esta a sua tarefa como força de intervenção social, qual seria ela então?). Mas vejamos: as camadas populares não liam. Nesse caso, para quem escreviam os neo-realistas? Ninguém soube criar, a este respeito, responsabilidades morais tão grandes. O paradoxo da sua acção literáriosocial é evidente. Por outro lado, tão-pouco realizaram, nas camadas intelectualmente interessadas, aquele convite à revisão de valores que é o primeiro sinal, no domínio da cultura, de uma proposta inovadora.

Aliás, parece existir algo de centralmente errado no realismo socialista, dado que não se produziu, em nenhum país do mundo, uma única obra superior inspirada pela doutrina. Será esse erro a recusa de urna dimensão metafísica? Maiakovski? Quem poderá resistir a citar estes dois períodos de Sophie Laffitte? "Dépassant la foule, de toute la puissance de son génie, Maiakovski subit le sort tragique de tout 
artiste qui renie sa nature profonde. Acculé a un impasse, il ne lui restait plus qu'a sortir de ce monde qu'il avait voulu recréer, plier à son orgueilleuse vision.” E, em todo o caso, a visão de Maiakovski vinha carregada do poder místico da tradição espiritual russa. Era uma visão. Mas hoje, utilizando embora o que nas circunstâncias seria uma ilegítima herança metafísica, quem poderia transformar em mito heróico o que é muitas vezes decepcionante experiência político-social?

Existe agora a obsessão do que se costuma denominar testemunho social. Quando um Homero explora o princípio do heroísmo e o valor apaixonado do acto humano, ou quando um Shakespeare levanta a problemática da razão envolvida pela paixão, ou ainda quando um Goethe caminha do direito a experiência total para o dever de uma ordem superior a paixão indiscriminada - não englobam a afirmação de uma urgência de definido testemunho do seu acto corno correspondendo a uma vivência geral do tempo. Então, acreditava-se no individuo, crença que certa filosofia ou certa pragmática não haviam posto em dúvida. Homero, Shakespeare e Goethe simbolizavam, no plano individual da criação, uma experiência humana.

Mas hoje deslocou-se a capacidade criadora do individuo para a comunidade, crendo que o individuo é apenas uma flexão do poder criador dela. Talvez pareça dignificar-se assim o individuo, por um lado, concedendo caráter universal ao seu acto; e, por outro, a sociedade, dando-lhe qualidade essencialmente criativa. Mas algo de vital se perdeu nesta operação - e essa perda, mal-grado as apressadas e solícitas correções posteriores, deu origem a um dos maiores equívocos da arte contemporânea.

Maiakovski instalou-se no ponto crucial desse equivoco. O seu principio da encomenda social da obra de arte ilustra sobretudo a terrível obediência do artista a instituição, partindo da ideia (por demonstrar) que a instituição contém em si os poderes originais da criação e os poderes criadores da originalidade. Se a instituição fosse, por definição, uma categoria revolucionária, é evidente que tudo estaria certo, mas a verdade é que ela representa o ordenamento congelado do impulso revolucionário que lhe deu origem. Só a instituição como elemento permanentemente revolucionário - o que é contradição nos termos - serviria a permanente afirmação revolucionária que é o acto de criar. Mas o movimento é qualidade da imaginação, quer dizer, atributo da individualidade - ao contrario da fixação institucional, da ordem, que é qualidade da razão, quer dizer, atributo da comunidade. É a esta individualidade que se recorre para ultrapassar o estatismo da instituição. Revolucionar é destruir a instituição. O artista deve, por conseguinte, opor-se, em sentido dinâmico, à 


\section{encomenda social.}

Maiakovski pagou caro a convicção de que a sociedade lhe pedia alguma coisa à altura do seu génio. O seu suicídio talvez sirva para garantir a visão súbita da contradição entre um destino de grande artista e um destino de homem social activo. Aliás, a decisão que tomou, no período imediatamente posterior à revolução, de abandonar a política em favor da actividade artística, partiria da ideia de uma incompatibilidade básica de duas tendências. Será excessivo afirmar que a actividade artística (o primado da imaginação, o direito do não aceitar os limites sociais, o carácter metafísico do acto criador) é, no fundo, anti-social, se concebermos a sociedade moderna como um espaço que se organiza em nome da ordem e da felicidade a certos níveis, contra os perigos da imaginação, do desejo e da metafísica?

$\mathrm{Na}$ realidade, o problema reduz-se ao choque entre dois grandes valores morais - a aventura e a ordem. Simplesmente, cada um destes princípios ganhou agora enorme poder e vastas implicações. A aventura é mais do que nunca intransigente afirmação individual e, sem dúvida, um acto radical no plano revolucionário. A assumir-se politicamente, só vejo que um artista possa ser anarquista - anarquista vitalício.

Simples confusão de interesses morais é o que está, por conseguinte, na raiz da adesão de um artista a tudo o que não seja o que Sophie Laffitte chama "sa nature profonde". Ética social e ética artística, quando confundidas, renovam perigosamente aquela atitude escolástica contra a qual o espírito moderno, desde a Renascença, se vem rebelando. $\mathrm{O}$ esforço da rnodernidade parece-me ser precisamente esse: libertar o espírito de qualquer moralismo. E lembremo-nos: na base do realismo socialista existe um ríspido rigorosismo moral capaz de, em muitos aspectos, avizinhá-lo da velha literatura de edificação e exemplo que alimentou as boas intenções de vários séculos da cultura cristã ocidental.

Nós somos um povo seriamente contaminado de moralismo, por um lado, e de esclavagismo sócio-político, por outro. Nada melhor para a criação de um mito optimista moralizante, dc beneficio popular. Se isso pode inspirar urna realização, o caso é que o nível do assunto não deve ser decerto o da ética artística. Questões destas resolvem-se noutras dependências da acção humana.

Depois, pensar que o acontecimento estético possui as mesmas leis que o acontecimento social, ou mesmo vital, é ignorar um ponto básico. A ser assim, não se compreenderia que o psiquismo humano tivesse necessidade de criar uma situação de vivência da mesma natureza de outras já existentes. Se o homem cria uma vida nova, é 
porque o seu espírito exige novas leis. O homem escreve um poema para se opor à vida e ao mundo, para negar o poder dos homens e libertar aquele "daemon" interior que, ao mesmo tempo que indica uma tensão criadora, manifesta igual tensão destruidora. $\mathrm{E}$ não se trata aqui sequer de considerar a liberdade individual do artista, mas de ser justo e inteligente para com o espírito humano.

Se parecerem demasiado longas ou um pouco inoportunas estas generalidades, considere-se que procuram caracterizar, do meu ponto de vista, a época em que decorreu a lenta e duradoura actividade poética de Edmundo de Bettencourt. E certo que tal época assume, nas circunstâncias, valor negativo e serve só, por contraste, para indicar a personalidade independente do poeta.

Escapando aos lugares-comuns de um tempo - tão poderosos e, aparentemente, tão irrevogáveis -, o autor de Rede Invisível assumiu, toda a vida, um silencioso desafio (e silencioso porque Bettencourt sempre fugiu à publicação) que, se significa a recusa de uma vida literária, mostra também discreta mas convicta desaprovação quanto ao papel que se vinha exigindo à poesia. Apraz-me salientar este significado moral de um silêncio de trinta e três anos. A decisão de se manter intacto dentro da sua própria aventura teria principiado já na época presencista, quando Bettencourt rompe com a revista e, ao mesmo tempo, não aparece na direcção da dissidente Sinal. Daí em diante haveria a posição solitária, a concepção da individualidade sistemática que se afirmaria pelo incómodo e fecundo repúdio dos grupos. Tal projecto vai custar-lhe algum esquecimento, pela parte do público e confrades, e a realização retirada de uma poesia extremamente pessoal e pouco referenciável às propostas das várias gerações que se irão sucedendo.

Assim, logo após a publicação de $O$ Momento e a Legenda, onde aparecem ainda alguns exemplos quase típicos de poesia presencista, o poeta começa a escrever os primeiros trechos de uma lírica que, alguns anos mais tarde, atingiria o completo desenvolvimento no conjunto Poemas Surdos.

De que é que primeiramente se desembaraça o poeta? Quanto a mim, ele desembaraça-se de dois grandes fardos. Primeiro: do narrativismo presencista, tão evidente sobretudo em Régio e Torga. Se é certo que, por vezes, o discurso ainda apareça depois nalgumas composições, será elaborado agora de outra maneira. Terá 
sentido mais moderno, quer por nele se deslocarem subjacentemente várias correntes que se interceptam, quer por os seus nexos serem mais de sugestão que de narração. $O$ discurso ganha urna polivalência de movimentos e significações que não possuía antes, dirigido como estava a apresentação de um tema e de um significado. É fácil estabelecer o elucidativo cotejo entre, por exemplo, Noite Ferida e As Meninas Velhas, no último dos quais a emoção é fornecida como que lateralmente e o significado profundo aparece para além das palavras, num momento posterior, deduzido do subtil contraponto entre duas emoções que as arcaicas e tranquilas tias e o mar dc onde o poeta regressa tendem a personificar.

Assim, parece-me que a primeira decisiva conquista de Bettencourt, com referencia à modernidade e à sua própria originalidade, surge na nova concepção do discurso.

O segundo passo é talvez ainda mais importante. Poderei chamá-lo, para simplificar (embora tal simplificação comporte riscos), o encontro com a imagem. A imagem (e tome-se o termo com o sentido que uma moderna nomenclatura lhe possa dar) conduzirá o poeta aos domínios da analogia, isto é, a uma nova noção das relações entre os elementos do real. Digo: concepção nova da realidade, consciência de inéditas dimensões dela. Pela aproximação agora possível entre as distâncias do real, pela capacidade de fusão de antinomias, a poesia de Bettencourt torna-se mais profunda, complexa e densa. O tema desaparece, ou fragmenta-se, ou somente se insinua, ambíguo ou pré-textual, apenas.

Hipotéticos encontros com o imagismo anglo-americano e o surrealismo francês, a lição rimbaldiana difusa na poesia europeia, teriam auxiliado o poeta na conquista destoutra dimensão da realidade. De qualquer modo, ela apresenta-se inteiramente pessoal.

Não é sem comoção que lemos os Poemas Surdos, lugar onde desemboca a terrível e libertadora aventura do poeta. Quando pensamos que esses textos foram escritos num tempo em que imperava a estética presencista e começava a instalar-se o dogma neo-rcalista, não podemos deixar de sentir um estremecimento. Estes poemas são, ao lado de algumas composições de António de Navarro e Vitorino Nemésio, a quase única reconfortante liberdade da poesia antes do aparecimento de Mario Cesariny e António Maria Lisboa. Mas António de Navarro é prejudicado por falta de atenção e excessiva confiança no acaso, enquanto Nemésio se prejudica a si mesmo pelas qualidades opostas. 
Sabemos que Bettencourt, durante o período, ou parte dele, em que escreveu tais poemas, viveu em circunstâncias especiais que não é lícito revelar, nem publicamente interessam. Basta anotar que esses textos nasceram de uma sobrecarga de emoção e imaginação que, normalmente, não é possível ou provável alguém possuir. Evidentemente que o caminho para eles fora iniciado já antes, nos tempos da Presença, mas podemos aceitar que circunstâncias especiais apressaram o seu aparecimento e lhes deram mesmo fisionomia própria.

Não sei o que melhor defina as composições deste período. O insólito das imagens e metáforas, o clima sufocante, a obliquidade da emoção, a medida onírica, o delírio gelado e nocturno - são aspectos seus menores ou fortuitos. Suponho que assentam, precisamente, na ideia de que a poesia não se propõe criar uma realidade poética a partir da realidade comum, mas criar uma realidade independente que se baste a si mesma e seja, ela própria, uma finalidade. A noção do poema como uma vida, organismo com leis específicas e realidade autônoma, é possivelmente a mais revolucionária proposta da lírica moderna. Ideia assente em Rimbaud, embora parcelar e timidamente crescida ao longo de muito tempo, determina o grande salto da poesia contemporânea, libertando-a de certo servilismo em relação aos quadros vitais e à experiência humana. Que a verdade está na imaginação não seria descoberta nenhuma, mas procurar que a própria imaginação deixe de contar com a tradição da realidade para a conquista de uma verdadeira vida e que (sobretudo isso) a imaginação encarregue o poema de realizar o acto de um corte decisivo com os princípios do humanismo e da experiência histórica do sentimento, da ética e da cultura - é algo de soberbamente arrojado.

Oportuno citar o que sobre o assunto diz Hugo Friedrich que, rnal-grado a sua simpatia pelas tradições humanísticas, seu gosto clássico e respeito pela concepção de linguagem como instrumento servidor de uma organização historicamente coerente do espírito - indica, com objectividade, o que foi o grande acto revolucionador da poesia moderna. "A partir de Rimbaud, o critico vê-e obrigado a recorrer heuristicamente à realidade como termo de comparação, já que só assim poderá apreciar até que ponto esta realidade foi destruída, assim corno com quanta violência se rompeu com o antigo estilo metafórico." [...] "Visto que esta (a realidade) é percebida corno insuficiente perante a transcendência, a paixão pela transcendência converte-se em destruição cega da realidade. A realidade destruída constitui agora o signo caótico da insuficiência do real em geral, assim como da inacessibilidade do desconhecido. Eis o que se pode 
chamar a dialéctica da modernidade."

Friedrich fala depois na afirmação de Baudelaire de que "o acto inicial da imaginação é uma decomposição". O ensaísta germânico sublinha que, nesta decomposição, se inclui, já em Baudelaire, deformação, princípio que “em Rimbaud se converte no processo efectivo da poesia".

Utilizando as suas insuperáveis (insuperáveis num homem tão universitariamente formado) noções de realidade, Hugo Friedrich observa: "Na medida em que se pode dizer existir, contudo, realidade (ou que podemos medir heuristicamente o poema tomando a realidade como critério), esta é objecto de dilatação, decomposição, tensões de contraste, até ao ponto de se tornar uma forma à beira do irreal." Depois, o ensaísta chama-lhe "irrealidade sensível", na impossibilidade (dele) de saltar sobre os princípios tradicionais das relações entre a poesia e a realidade fornecidas pela cultura e vivência histórica.

Friedrich - inteligente, douto e consciencioso espírito humanista - não se livra de ficar abrangido naquela impiedosa frase de Pierre Reverdy: "Tem-se mais o hábito da vida do que da arte. Apresentar urna obra que se eleva acima desta aparência é exigir uma formidável mudança de hábito." Com efeito. "A realidade", diz ainda o poeta francês, não motiva a obra de arte."

É evidente que as palavras utilizadas por um poeta carregam aquele valor real da designação e referéncia - do mesmo modo que o poeta maneja parcelas de uma experiência emocional e mental referidas aos quadros gerais da vivência humana. Contudo, o objecto a que a experiência e as palavras se dirigem já nada tem a ver com a realidade e a linguagem da história. Há uma nova realidade. É o poema. Assim é que se pode dizer possuir o poema existência tão própria, independente e suficiente como um corpo. As suas leis são as de uma nova realidade - a realidade do poema.

Parece-me que, neste aspecto, Edmundo de Bettencourt logra não só conseguir alguns poemas onde esta existência se releva das estruturas circundantes de tempo e espaço, isto é, da cultura e quotidiano - mas assume uma atitude sistemática de agente da realidade do poema. Nomes como os de Camilo Pessanha, Ângelo de Lima, SáCarneiro e Fernando Pessoa servirão para indicar o que uma posição de modernidade atingira já antes entre nós. Mas qualquer deles não descobriu a tempo, ou não descobriu bem, ou descobriu tantas coisas que não podia ter descoberto tudo - não somente que "a poesia é o real absoluto" do romantismo alemão, mas que é um absoluto real e que o poema é a realidade desse absoluto. 
Chamar imagistas ou surrealistas aos textos do Bettencourt desta altura pareceme pouco louvável esforço de enquadramento, próprio só de gente a quem incomoda que o acto pessoal não seja reportável a linhas estabelecidas. Eles distinguem-se do imagismo pela falta de propósito em criar uma imagem como realidade final de um movimento psicológico, além de a imagem possuir em Bettencourt valor menos representativo do que dinâmico. Não sei em que se distinguem do surrealismo, se concebermos que a Bettencourt não falta confiança nos poderes activos da imaginação, nem força para ultrapassar todas as antinomias, sobre cujo movimento alternado se estabeleceu o conhecimento tradicional. Mas quando se fala em surrealismo, apesar de ele haver precisamente procurado aniquilar a literatura como propósito, pensa-se num típico estilo literário datado de mil novecentos e vinte e tal, trinta e tal, França. Assim, nãoo há vestígios no nosso poeta de lição surrealista. Mas há propósitos surreais, ou pontos de chegada que se avizinham de uma consciência de surrealidade, como os há cm Ângelo de Lima, Sá-Carneiro e Pessoa - e os houve em Saint-Pol-Roux, Reverdy ou Perse. Surrealismo é uma incómoda designação escolar que os surrealistas nos forneceram. Não será surrealista (despido o termo do equívoco geracional) todo aquele que transpôs a noção tradicional de realidade, essa mesma a partir da qual Hugo Friedrich se horroriza de Rimbaud, o irrealista, o corruptor da realidade? Nesse sentido, Bettencourt, poeta moderno, é surrealista. Surrealistas, decorrentemente, a sua vocação de liberdade, o conhecimento de um lugar real superior onde se dá a unidade do espírito, a confiança na imaginação como agente recuperador de um mundo que a cultura atraiçoou.

Poemas como Ar Livre, Nocturno Fundo, Noite Vazia, Vigília, Atmosferas, Abrigo, Circunstância são, porventura, os mais altos exemplos desta fase, aqueles em que melhor se atesta o esforço para realizar um espaço poemático completamente coerente na sua estrutura e respondendo à necessidade da imaginação de criar uma vida eficaz para superar a vida sem coerência, sem unidade, sem surpresa, sem plenitude, do chamado real quotidiano. Estes objectos terríveis, respirando na sombra, organizados como corpos que tivessem abolido barreiras da ordenação biológica, no entanto corpos organizados - apelam para a exaltação de certas forças sombrias e implacáveis que o espírito escamoteou, para que no real se pudesse instalar a cidadania. Como um poeta português, situado entre o presencismo e o neo-realisrno, pôde levar a efeito essa tarefa, nos anos 1930-40, é coisa que me surpreenderia, se eu não acreditasse haver homens, em todas as circunstâncias, capazes de preservar a sua individualidade e 
corajosos bastante para a marginalidade e a solidão.

A evolução posterior de Bettencourt fez-se noutro sentido, sem que determinadas conquistas-chave do percurso anterior tivessem sido totalmente abandonadas. A tal evolução não me parecem estranhas as personagens de certo Fernando Pessoa e de Afonso Duarte, embora aqui se não fale de influência, mas de posição e exemplo.

Eu suponho, apesar de todos os equívocos (alguns conscientemente forjados) que noções corno romântico e clássico possam ter criado, comportarem estes termos bem definíveis conteúdos em referência à posições distintas do espírito perante o acontecimento e a linguagem. Distingui-los como apenas dois movimentos de um mesmo acto não me parece destruir a diferença de situações que implicam. Podemonos reportar à concepção nietzschiana da tragédia grega e colocar a força dionisíaca (romântica) como impulso criador e a força apolínea (clássica) como a consecução de uma linguagem organizada. Os interesses da expressão podem, no entanto, ser outros que não a comunicação ao nível de um entendimento clássico (a transformação de caos em cosmos), como acontecia na tragédia grega. Vimos já como, segundo a intenção rimbaldiana, o poema - finalidade em si mesma e realidade bastante - se consuma e organiza a um nível que repudia as ideias antigas acerca de ordem, realidade e comunicação. Eu, por mim, não compreendo como um moderno espírito romântico (e penso aqui em toda a grande poesia pés-rimbaldiana, incluindo o surrealismo) possa caminhar em direção ao classicismo, ainda que se diga dever (ou poder) cada qual encontrar o seu próprio classicismo. Mesmo que a situação dionisíaca e apolínea correspondam a dois níveis do mesmo impulso, à maneira nietzschiana, não entendo que a surrealidade, quero dizer, a situação dionisíaca extrema, pretenda dispor-se para uma organização implicando fé num tipo de linguagem e comunicação que negaria certas recusas fundamentais do romantismo moderno. Todos quantos em certo momento acreditaram no entusiasmo (entusiasmo, no sentido holderliniano), numa visão do mundo em que o homem participa inteiramente na sua visão, confiança com que se fez coração do mito - todos esses podem muito bem, em dada altura, caminhar noutro sentido. Mas isso significará, no estado presente da aventura romântica, uma ruptura com a crença anterior, a crença na unidade intrínseca da paixão que prescinde de formas intelectualmente acessíveis de comunicação.

A Última fase da poesia de Edmundo de Bettencourt antolha-se-me como uma rnodificação básica de atitude. Não atinge tal modificação diferença de qualidade, pois 
Bettencourt conserva-se o poeta que é. Mudança de atitude a que subjazem interesses psicológicos que não seria fácil estabelecer - apenas isso. Mas a partir de agora - e a exemplo daquela figuração de Pessoa desempenhada pelos poemas ortônimos e por Ricardo Reis, a exemplo ainda pela objectividade, a organização plástica e o valor objectual da linguagem do penúltimo e último Afonso Duarte - Edmundo de Bettencourt apresenta urna vigilância e interesse pelos signos exteriores acerca dos quais se pode utilizar a palavra clássicos, não falta - curiosamente - a ironia, embora muito subtil, quase desatenta. Esta economia irônica na construção do poema não despreza, contudo, o exercício libertário da imaginação que dá chaves para lugares onde a concepção da economia é insólita, o que torna Bettencourt uma espécie de romântico que encontrou o seu próprio - mas irônico - classicismo. Ambígua nos seus propósitos e fundamentos internos, secretamente contraditória, alguma da poesia desta última fase. O que lhe empresta, aliás, novo interesse. Esta interna contradição, essa interna riqueza desavinda, provém assim das bases românticas de uma personalidade que possui, outrossim, consciência da validade cultural da arte e da validade moral da cultura. Pessoa - e penso também no nome de Jorge de Sena - possuía estes dois aspectos - o amor da estabilidade emocional, com o seu cortejo de consequentes qualidades, e o fascínio da aventura, com todas as negações humanísticas que comporta.

A Europa, levada pela ideia do impasse criado pelo surrealismo e pela impossibilidade de reinventar a crença (demolida irrevogavelmente) nos ideais da cultura ocidental, lançou-se na provisória solução desta ambiguidade. Ambiguidade que, carreada por outros lados e com a fisionomia epocal própria, foi já a de Goethe, por exemplo. Assiste-se talvez ao moroso e irremediável desmoronamento interno de toda a cultura ocidental. E desconhecemos as soluções, se é que as há.

Entretanto, o dramático esforço de Orfeu, que desce aos infernos para reunir a sua dispersão na unidade final do canto, é tarefa para cada um - e isso nos baste, mesmo que não sirva para nada, além de servir para a provisória salvação de quem nela se empenhe. O mito de Sísifo, de que fala Camus.

Estamos aqui perante um poeta raro que um enorme silêncio escondeu do público. Do ponto de vista literário, esse silencio prejudicou-o, pois o que seria estupenda novidade em 1930-40 perdeu um pouco de interesse, agora. Não decerto o 
melhor dele, o que é permanentemente novo num poeta, mas apenas aquelas surpresas laterais que para um Apollinaire constituíam um dos valores fundamentais da estética moderna. Claro que os poemas de Bettencourt surpreenderão hoje e amanhã, mas eu gostaria de lhes ver atribuídos - e sê-lo-iam - certos arrojos, novidades, experiências, que hoje já lhes não serão. Isto, contudo, diz somente respeito à literatura e, mesmo assim, a uma província menor dela. A grande originalidade tem outros sinais e, mesmo quando considerada literariamente, não se perde por causa de aspectos secundários.

Trinta anos de silêncio pediam que o poeta fosse apresentado ao público. Essa difícil tarefa requereria um ensaísta, e não um simples admirador da sua poesia. Umas notas escritas apressadamente por alguém que não possui nem a prática nem a vocação críticas arriscam-se a dificultar, em vez de tornar mais acessível, a leitura de uma poesia tão rica como despistante, tio original como complexa, tão estranha como bela. Muitos aspectos - alguns importantes - da obra de Bettencourt nem mencionados foram ao longo destas linhas. Como fazê-lo senão através de um estudo paciente e minucioso que nada autoriza que eu faça? Limito-me a consignar, em meia dúzia de páginas, o que me pareceu imprescindível e se refere à maneira pessoal como fui tocado pela poesia do autor de Rede Invisivel, e também a alguns dos problemas gerais levantados por ela.

Creio que se houvesse tido o cuidado de aparecer há vinte anos, Bettencourt se arriscaria a ser posto à margem, ou influiria então decisivamente na lírica portuguesa posterior. E, se influísse, talvez se apressara o que tanto tardou - o aparecimento de personalidades como Cesariny e Lisboa e, com eles, a formação de uma sensibilidade que ainda muito a custo vai transformando o gosto de um pequeno público, como é sempre pequeno o público cronologicamente correspondente à criação avançada.

De qualquer maneira, cabe a Bettencourt a honra de ser uma das pouquíssimas vozes modernas entre o milagre do Orpheu e o breve momento surrealista português.

Presumo ser a partir de Orpheu, desses poucos poetas posteriores e do surrealismo - nesta linha, e para diante - que alguma coisa nova e bela poderá surgir na poesia portuguesa. Talvez então se conceda a Edmundo de Bettencourt, e a alguns mais, o lugar de relevo que é seu.

(1963).

Post-Scriptum - Agora o texto não está enquadrado. Estava enquadrado 
primeiramente, 1963, quando pretendeu introduzir os até ai quase todos dispersos Poemas de Edmundo ale Bettencourt. Era o tempo da ditadura neo-realista.

Como sempre, como em qualquer sistema de autoridade, toda a gente fazia parte dela, incluindo as vítimas. Mas as vítimas não escreviam nos jornais. A ditadura escrevia neles todos: revistas, jornais, livros, tudo. De modo que o texto foi compactamente desancado. $\mathrm{O}$ autor, que não estava ali para outra coisa, rejubilava. Tinha razão, uma razão fora daquilo que acontecia, uma razão depois. Não se considerava precursor de nada; sabia só que a razão dominante tinha o espaço inteiro e a força de ter para si o espaço inteiro. E alegrava-se disso, o autor, alegrava-se de não estar contido naquele espaço senão como vítima. Entretanto não constavam do texto méritos particulares. Era até canhestro, e abundante em observações ingênuas, previsíveis de futuro sem futuro à vista, para já não falar de muitas inocências estilísticas. Não era o que deveria ser: uma analise da poesia de Bettencourt. Ser, ambição maior, um exemplo condizendo com as palavras de Breton: "[...] toute speculation autour d'une oeuvre est plus ou moins stérile, du moment qu'elle ne nous livre rien de l'essentiel: à savoir le secret de la puissance d'attraction que cette oeuvre exerce". Enfim, o texto mostrava unicamente o seu amor inábil. O amor inábil não ajudava. E então os guardas vermelhos precipitaram-se sobre o escrito do amor. A notícia que iam dando dos poemas propriamente ditos era vaguíssima.

Isto é: o texto não servia senão para a psicoticamente exultante pancadaria crítica. Foi uma festa. O introdutor tinha portanto as suas razões, mas eram um pouquíssimo ganho para quem desejava sobretudo que as pessoas se interessassem por umas duas dúzias de poemas soberanos que vinham dentro do livro. Custava que a algazarra dos directores espirituais não permitisse escutar a música sussurrada, custava que os poemas desaparecessem entre a inabilidade introdutória e a inépcia neo-realista.

Bom, foi tudo chão de uvas, acabou, não interessa, não existe. E, sabendo-o, o introdutor não queria reeditar o texto, queria dar o escrito por não escrito. Insistiu-se contudo em que o texto se enquadrava. Ah sim, haveria um texto para enquadrar de novo, mas não era aquele, porque o quadro era outro. Embora fosse semelhante o professorado, sempre os maîtres à penser, sempre os que dizem como está bem e como está mal. Porque, não tenham esperança, a escola não finda nunca, o mais prodigioso nela é mesmo essa capacidade de nunca findar, de recorrer continuamente a múltiplas formas de vigência. Eis do que ela sabe, é a sua única sabedoria: dizer sem parar como é. 
Volto-me um bocado para trás e vejo como era. Havia dois poderes: o do regime político e esse, o cultural. E é terrível supor que o segundo era poderoso apenas porque o primeiro achava que a cultura não tinha importância nenhuma. E não tinha de facto, pois se consumia na cena cómica de os autores se lerem entre si e a grande população dos outros ser analfabeta. Mas é tão passado, tudo isto, tanto que serve só para encobrir o presente. E no presente aquilo de que se pode tratar é do analfabetismo democrático e dc um caldo de culturas tão pobre em vitaminas que está fora de qualquer hipótese alimentar. A reserva tenaz e silenciosa fica em casa a dedicar-se a si própria e, fervorosamente, a saber que não está em dia.

O texto não propicia coisa nenhuma, nenhuma verdade, nenhuma evidência. É desajeitado, como no seu tempo de bulício, e inactual nos termos. Serve ao menos como documento histérico, como depoimento de uma época transacta? E se servir, para que serve isso? Sou pessimista desde o coração à cabeça. Não creio na ressurreição dos corpos e das almas. Nem creio sequer que as pessoas não-analfabetas saibam ler, e menos ainda creio que saibam ler poesia. E quando parecem saber, vai-se ver e é um equívoco. Lêem errado. Verifico mais do que suporto verificar que se pega em tudo pelos lados de fora, e se não vê aquilo que esperava ser pegado e visto pelos lados de dentro. Ora isto não põe muita fé nas transformações verdadeiras, e parece-me que Edmundo dc Bettencourt escreveu os seus trinta poemas expoentes para aqueles tais que ficam em casa com a pouca poesia que se vai exorbitando.

E nada há que nos valha, nada para dizer.

(1999).

Herberto Helder

(In: Poemas de Edmundo de Bettencourt. Lisboa: Assírio \& Alvim, 1999, p. 8-29) 


\section{ANEXO F - CENA VOCAL COM FUNDO VISUAL DE CRUZEIRO SEIXAS}

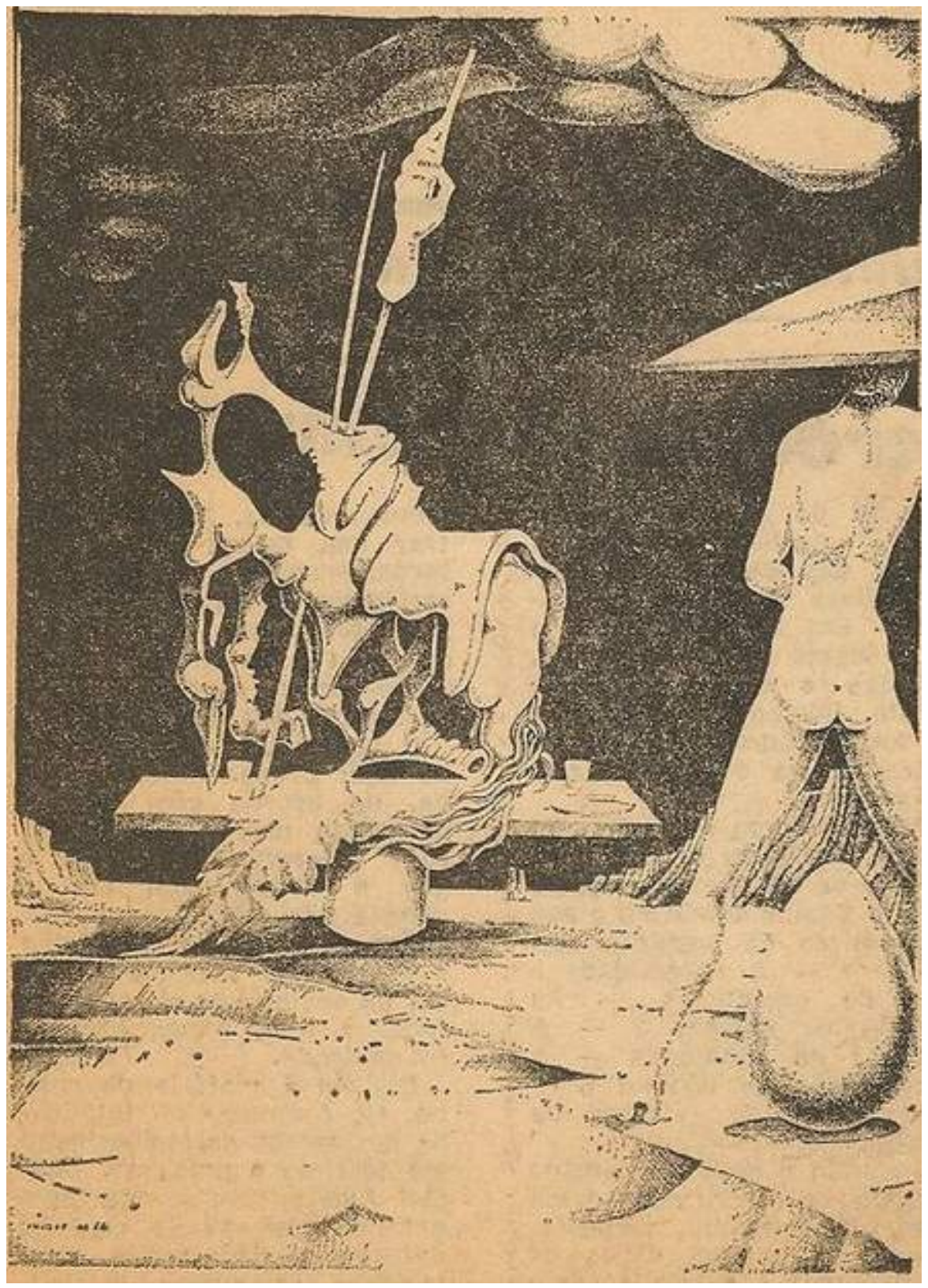

- Quero dizer algumas palavras simples sobre o talento - diz a Voz. - O talento é a possibilidade da pessoalidade. É preciso abolir todas as falas acerca do talento. Sufocam-nos; cortam a redação do espírito, a modulação, a pronúncia.

O talento é cada um. Ninguém é tão próprio como ele próprio.

A operação primeira do talento consiste em colocar-se a pessoa numa posição estudada de dentro. Deve tudo ser disposto na direiteza das linhas do operador. As linhas configuram a memória guardada, de maneira que o fito desta fase operatória será conseguir a coincidência das imagens interiores com a percepção do instante.

Tudo quanto há já foi visto, existe como forma ou sistema de formas. O espírito 
organizou-se com essas imagens, que se não encontram em estado de dicionário visual, mas são internamente orgânicas, são uma experiência de constituição.

A forma do mundo que somos deve adaptar a forma instantaneamente havida lá fora, através de uma sintaxe mental severíssima. Este engrenamento é uma espécie de boa vontade intelectual, uma ironia de ser que, de passagem, se creditou aos auspícios e desígnios da razão.

E o nosso corpo, que é o fremente corpo das imagens, as imagens encarnadas, impõe a emenda do mundo. Não por esse acto um tanto ingênuo de altercar com alguma sintaxe, cometimento este de imaginações artesãs, mas por uma coragem grande do corpo pessoal, que tem de obrigar e sujeitar as figuras flutuantes do mundo.

O talento principia a ser um jogo de mãos exercido no âmbito da incoincidência, no sentido sempre da dimensão e qualidade desse desvio. O desvio é o palco e devemos saber tudo acerca do palco.

O palco é a zona da acção. Colocados num ponto do palco, começamos a fazer gestos para as coisas, a chama-las, a incitá-las, a mandá-las para aqui e para ali, a darlhes ordens.

Que são estas ordens? Como são dadas estas ordens?

São dadas com desenvoltura, com astúcia, e referem-se ao assunto do comportamento.

As coisas têm de comportar-se, possuir um porte com: as outras próximas, connosco. Devem saber por onde mover-se, a que ritmo, de que modo. E em que sítio parar, e a maneira como, e a postura em que.

É preciso dominá-las bem. Disso depende tudo, porque o talento está a fazer a cama onde se há de deitar. Verdadeiramente, o talento está a fazer-se. Porque o talento é a própria matéria organizada por mando do talento. O talento é-se.

A aranha tece a teia. O talento cria a sua esfera, que é a esfera do mundo: e o mundo é o corpo mesmo do talento. Mas o mundo está dentro do talento, e o que o talento também faz é pô-lo fora, à vista, como paisagem ou espetáculo ou ilusão vivente.

O talento trata as coisas como um domador trata os animais, insinuante e imperativamente. Seduz, induz, comanda, chama, afaga, afasta, cerca. Tudo isto com palavras e silêncios, com gestos, andando à volta, hipnotizando às vezes, dizendo que não e que sim. Ajuda-se de luzes. Ajuda-se de escuro, onde também pode lançar gritos repentinos. As coisas devem ser muito bem manobradas pelo talento. 
O talento - diz a voz - é a coordenação viva de duas ordens de imagens vivas: as imagens da memória, e as da actualidade agente. A norma do talento é imaginar as incoincidências vivas entre elas.

Apaguem essas palavras ouvidas - diz a voz -, porque o talento deve inventar as regras do talento. Pois nada é como se diz, mas sim como se faz, como se apresenta.

E como se apresenta? Apresenta-se apresentando; faz-se de dentro para fora. Dizem que o talento é uma ideia, um conceito, um preconceito. Pois digamos que não existe, que existe a acção. O que importa é o escândalo. Falemos da acção.

- Quero dizer algumas palavras simples sobre a acção - diz a voz. - A acção é a possibilidade da pessoalidade. É preciso abolir todas as falas acerca da acção. Sufocando-nos; cortam a redação do espírito, a modulação, a pronúncia. A acção é com cada um. Ninguém é tão próprio para ela como o próprio. Etc.

HERBERTO HELDER, no catálogo da exposição de Cruzeiro Seixas, que está patente, desde terça-feira, na Galeria São Mamede e à qual pertence a gravura que reproduzimos.

(HELDER, Herberto. Cena vocal sobre fundo visual de Cruzeiro Seixas. Lisboa: Diário de Notícias, 19 de junho de 1980) 


\section{ANEXO G - O CADÁVER ESQUISITO E OS ESTUDANTES}

Sem título.

Principalmente devido a José Sebag, este cadáver Esquisito Heterodoxo foi lido pelo mesmo José Sebag na Faculdade dc Medicina, dc Lisboa, corno presença crítica na exposição "Sete jovens Pintores Portugueses", ali efectuada.

Herberto Hélder, João Rodrigues, José Sebag.

(Café do Gêlo, 1957.)

Em 1 das salas menos para o efeito do vetusto edifício do acolhedor e rancoroso campo de Santa Ana vulgo patriarcado, alguns pintores, vates, jurisconsultos, nus ou afogados e em qualquer dos casos barbeiros profissionais, examinaram à lupa a própria lupa sobejando por conseguinte, em vista às consequências legais, que como paras anteriores cantavam com chineses sobre uma península de plasma tipografada em normando no mais babélico estilo de camarada. (Vibrantes, quentes, acessíveis, delirantes, essenciais - exteriorizações de aplauso entre frenético e olvidado aparecem grandes cabeças dc recém-nascidos legais, amarfanhando as telas até tê-las e dizendo - que bem esgalhadas desvairadas telas.

Mais vale sê-las que parecê-las. Não queremos esquecer nesta breve reportagem a figura incompreendida de catedrático mendigo comendo vorazmente dulcíssimas canetas esferográficas. Recordando aos mais esquecidos a génese dos chapéus em forma dc cogumelo, venenoso ou não, para o caso não interessa, não podemos deixar de mencionar o sinistro ocorrido na via láctea durante as horas de mais movimento; grandes máquinas dc guardar lábios segregavam umas às outras com baba ministerial casos do dia ocorridos de noite mas assim apresentados para defender as bolachas ao rato.

Invasões de negras formigas trepando pelo Parténon enquanto ruídos inopinados de máquinas de escrever urdiam 1 clima de pneu comovido. Pessoas entravam e saiam. Depois de 8 - séculos -8 sósias entre si, 1 grupo de soluções do tamanho de salas de espectáculo tenta a sua própria liberdade e juventude, entenda-se flores (magnólias, miosótis, açucenas e violetas). Acabou-se a era da livre comunhão na base dos sorrisos pequenos como caixotes ou apertos de mão - cancela aberta para 
os ventres das mais queridas filhas. Congratulações foram esquecidas, mortos ficaram por queimar, monges penteiam-se no bojo dc aviões, mães sorriem ao postigo, piolhos assomam is nuvens, cafés arrefecem entre duas esquinas de vento. Eucaliptos de tédio urinam sobre os nossos mamilos, mãos aparecem junto a partes ocultas do corpo que se azula e por cima de tudo isto, enchendo tudo isto, sendo isto, abrimos o nosso guardachuva de glória em forma dc vareta, enquanto alguns mais impertinentes recusam a tempestade aconselhando-nos uma caligrafia engaiolada na razão das razões (Spinoza). Temos é certo praticado bastante o alpinismo, lido os jornais, bebido o seu deles vinagre chorado, vestido o paramento litúrgico dos lamas e grandes espartilhos salvadores, como carta com aviso de recepção. Ao fim de dez lances de escada, surge o quadro em suas dimensões próprias, ainda que insólitas. Pergunta-se: o que é o quadro? Vago relógio falante, búzio iluminado, parasita combatido, magia drástica, recosto lateral, busto de mulher, susto de tetrarca, letra cinzenta no guiché da mais próxima repartição, não-envernizado pano de fundo, e porque não pirâmide entre a areia? Açude de boas e más intenções, pinote a trote sobre o bote da mascote, enfim, itinerário de compromissos morais, mera província sem planta volante, órbita sem dono, equilíbrio de fastios vários, fogueira alacre sobre o iceberg quebra-medos, íntima aliteração.

No mais refinado ambiente, às onze prefixas, inaugurou-se a exposição anunciada; milhares e milhares de estudantes de ambos os sexos vieram comer os seus lanches, se atropelando para garantir a eficácia da organização. Passando $1^{\circ}$ momento de pasmo geral, ao som triunfal de trombetas e ferrinhos deram entrada as famílias dos alunos de chapéus na mão, de chapéus na cabeça, de chapéus nos chapéus e de cabeça nas paredes. Críticos principiaram a tomar os seus apontamentos, gravados a tinta da china nas costas de pesadíssimas virgens trazidas para o efeito. Afastadas as mesas de jogo deu-se inicio ao sorteio. O jogo é simples - bola ou cruz toda a gente sabe. Quando sai bola pega-se na cabeça do premiado, entala-se entre os joelhos e arrancamse os cabelos um por um até que o paciente reze as suas primeiras e últimas orações. Se sai cruz (importantíssimo) evanescentes grilos com os olhos de noite na água do amor moreno ao vento (vide ÁRVORE) ladeiam o premiado fazendo simultaneamente algumas gaifonas ao assistente, trazem-no de rasto junto ao juiz. Este diz: - Acabou por hoje. Distribuam-se os prémios dc consolação e despejem-se os espectadores nos bolsos da eternidade.

E assim há muitos anos. 
Recusamos o consolo moral, recusamos o sofá da adjectivação, recusamos o cachecol Luiz Francisco Rebelo, o mundo não começa às nove e quarenta e cinco como se disse, recusamos o ascensor, a refeição burocrática, o aquecimento central, a entrada com bilhete, o pequeno almoço na cama, recusamos a casa da misericórdia, a viagem pacífica, o artigo de fundo, a teoria do espaço curvo, o Mário Braga, a transfusão de sangue, o Papiniano, o non-plus-ultra, a grande saturnal das opiniões, o consenso público, o público com senso, o cotovelo que adverte, recusamos a sintaxe, o Alvim, o amendoim, outrossim recusamos o passeio dominical ao parque, a arte, a calvície dissimulada, o vaso de cama, o bípede implume (Platão), a rede de esgotos de que fala Victor Hugo, o Tejo dos maus versos, o estilo manuelino, o concreto dentro do abstracto, o hálito matinal do abraço a comissão de festas.

Aceitamos o algodão em rama, bem como o iodado, alguns nomes escolhidos ao acso nos arquivos de identificação enquanto só nomes; nomes feios, pronomes, alguns substantivos cômodos, a ira, aceitamos a confusão, aceitamos dinheiro, gêneros alimentícios, cobertores, apitos, actores, gritos, estertores, conflitos, detergentes, antissépticos, anti-histamínicos, alguns anti-bióticos e Boas-Festas.

Definida a nossa posição passamos a assinar.

\section{HERBERTO HELDER \\ JOÃO RODRIGUES \\ JOSÉ SEBAG}

P.S. - Aceitamos também os touros dc morte.

\section{HERBERTO HELDER \\ JOÃO RODRIGUES}

(In: CESARINY, Mário. Antologia do Cadáver Esquisito. Lisboa: Assírio \& Alvim, 1989, p. 66-70) 
ANEXO H - Documento: censura de Apresentação do rosto

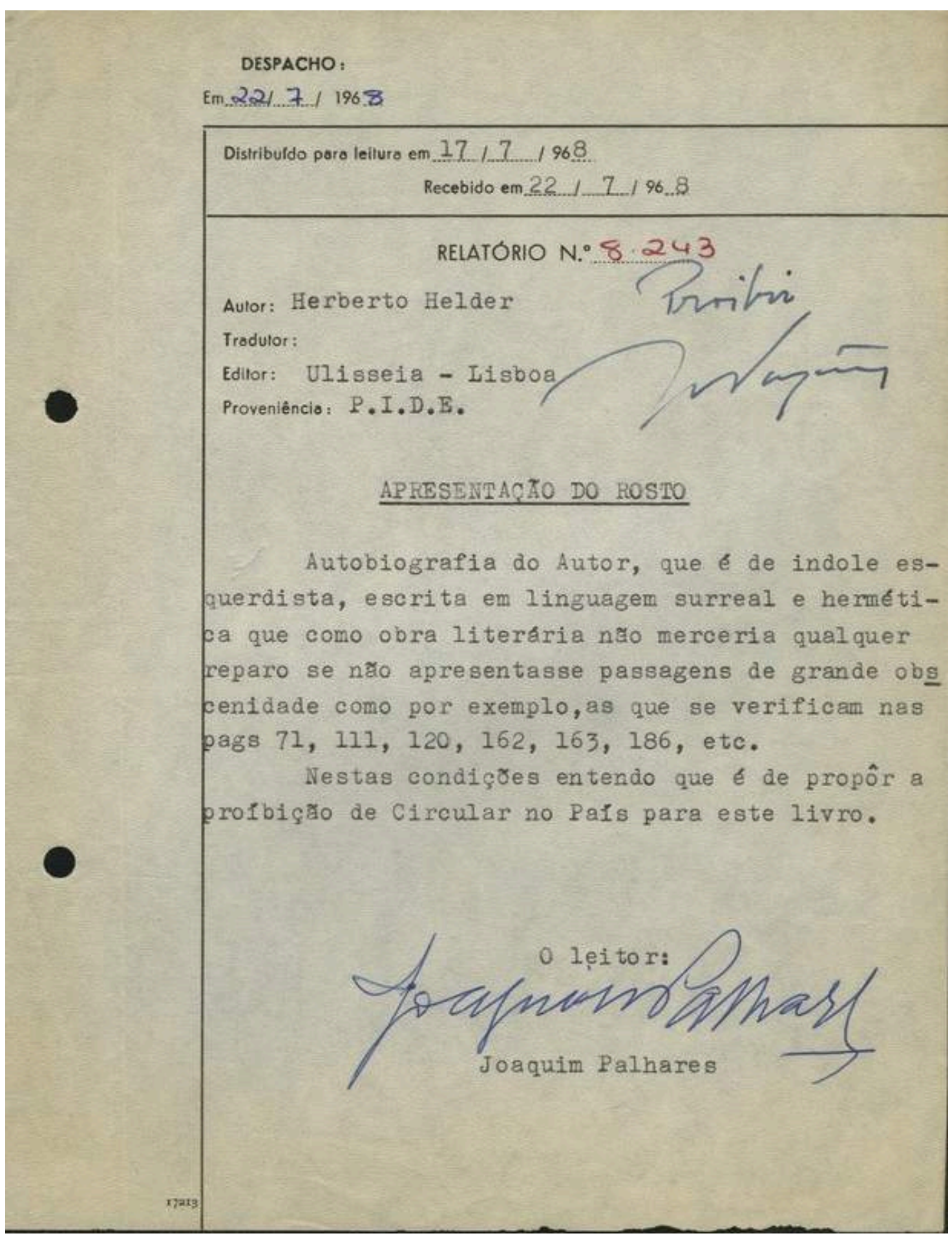




\section{ANEXO I - CESARINY SOMBRA DE ALMAGRE}

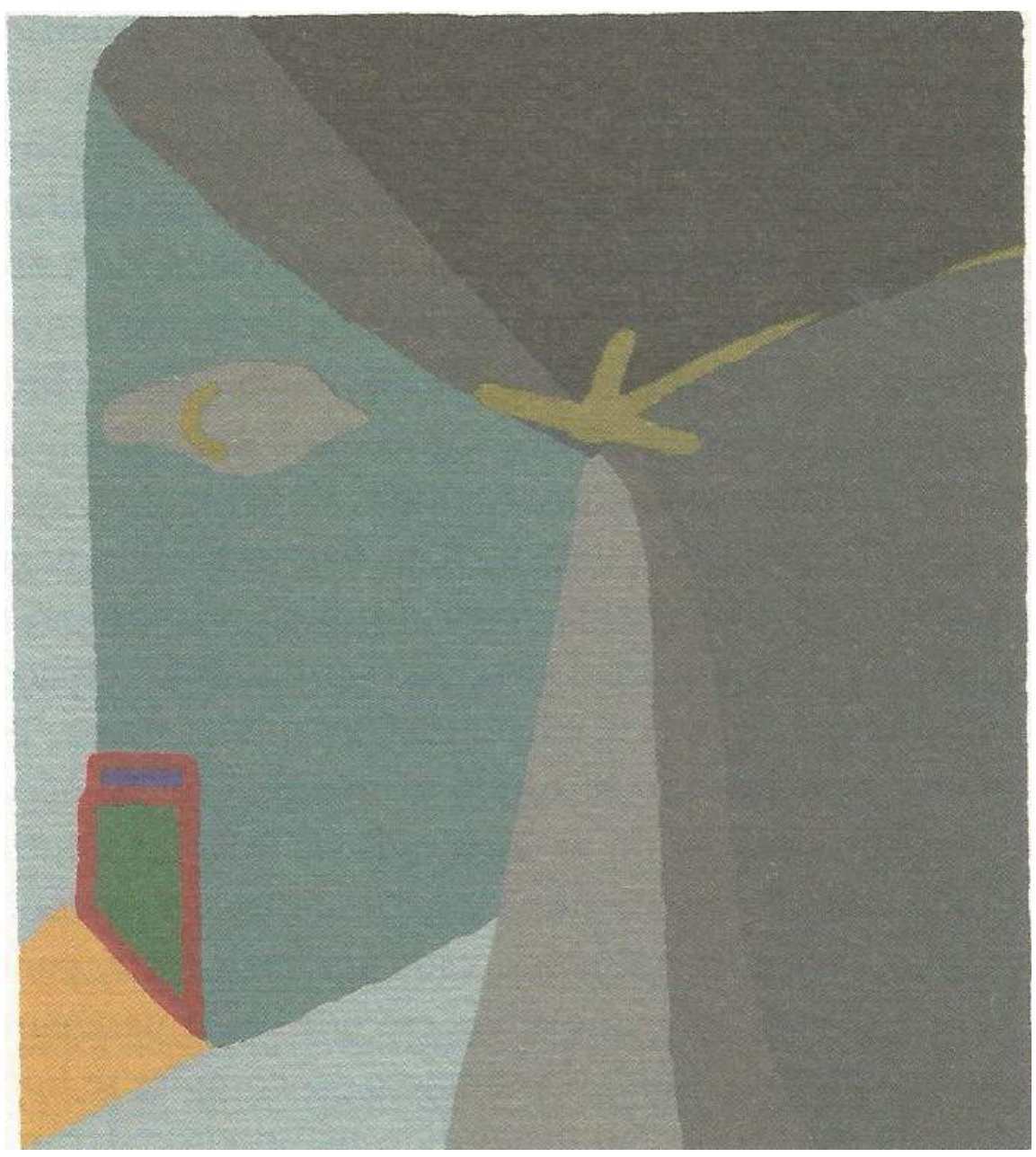

CESARINY SOMBRA DE ALMAGRE

Herberto Helder

(Em Abril de 1984 foi distribuído o pequeno volume "Sombra de Almagre", poema e serigrafia do Cesariny; o cólofon indicava que a composição e a impressão se tinham efectuado em Dezembro do ano anterior. No $5^{\circ}$ verso do exemplar em minha posse o autor corrigira a palavra "milímetro" para "mililímetro". Quanto à serigrafia: na parte central, desviada ligeiramente para a direita, ascendia uma espécie do colina com, figuremos assim, uma coroa estelar de quatro pontas. Em baixo, à esquerda, machas vermelhas e verdes; sobre elas, ao nível alto do tetrestrela, uma forma ocular cinza, uma unhada amarela. Transcreve-se o poema para que ganhe algum sentido a metáfora em prosa derivada.) 
sombra de almagre

Buraco-negro-com-barba-postiça-de-Newton

ou pirâmide de De?

A pirâmide de De

com saltos altos e rara elegância de meios

caminha um mililimetro por segundo

em direcção a Maar

O qual em movimento inverso se expande

(tahafut-ul-tahafut) à razão

de 2 tri-leões por sebe. Por

outro lado

Se houvermos por verídico o retrato

que Blake fez de Newton

este NÃO TINHA BARBA (relativamente) (nenhuma)

e assim

Não haverá

qualquer porção

de almagre

O espaço come porém não altera

que os poços escaleres

possam nunca afastar-se

(ou precipitar-se)

de De

ou de Maar 
Em Dezembro as oficinas trabalhavam, mas foi preciso o equinócio da Primavera, ar limpo, corações inocentes, mais ardentes as cabeças, para que ficasse à prova de vista a cor do almagre, almagra moura, vermelha. Creio que as palavras da inocência designam uma razão imponderável mas muito activa. Não se conhece bem a razão desta razão, de que zonas para que zonas remete o poder. Quando a tipografia me deu o vocábulo "milímetro", achei bem nos dicionários do sistema métrico decimal, era uma razão acomodada, corrupta, trocava-se em medida de qualquer coisa. Não me perturbou. Fornecera-o o comércio das chitas, não vinha de nenhuma desocultação do oculto. Mas achei melhor a emenda para "mililímetro", ali feita como luz, a distância que fulmina entre a cabeça sensível e o coração pensador. Era o equinócio. E ponderei outra distância, rítmica aos ouvidos, visível à atenção entre uma estrela na carta e a outra estrela, a dupla, porventura fora da carta: silêncio. Sei que o espaço entre dois versos, duas linhas de inteligibilidade cíclica, pode ganhar uma extraordinária transparência ao considera-se como silêncio, e essa distância balanceada e grave é decerto, acho eu agora pela errata minuciosamente simplificadora de Cesariny, "mililimétrica". Parece que em Zurique o século quase principiou por compor um silêncio puro no centro imperativo da gramática, à custa de alguma vozearia de combate. A força da regra, que se ajuda na regra das excepções, não resiste a dois ou três movimentos esferográficas da mão, rápidos, chegados da inteligência que se anima nas lições do mundo, no almagre cor de sangue. Na substancia onde mexem, os dedos tomam o modo oleiro, ou o modo de hélices misturando o ar, ou o modo refracto de uma estrela nas águas. Fazem-nos todos o favor óptimo de redemoinhar. Como o sangue almagre em coração, cabeça e estomago. Esta "aventura na irrealidade imediata" - di-lo-ia Marcel Blecher (não é francês, como o nome não indica) -, esta poesia enormemente súbita das coisas nas suas designações, é mostrada, transposto o anúncio prometedor da serigrafia, no poema equinocial, primeiro, nominativo, mágico, co-rítmico, almagre, de Cesariny. As palavras andam tão encontradas pela pronúncia que a constelação, quando o olho tóxico lhe cai em cima, parece apenas uma neve carbônica expelida por um tubo sonográfico ligado ao motor de explosão dadá-surreal. Estacaria tudo no semáforo mais próximo? Mas nada começou, pois em cada tempo é tempo de começar. Talvez Almada também o quisesse dizer. No momento-Cesariny, este, há uma aurora dadá-equinocial-surrealista que aclara, pelo método antinômico da obscuridade, a vida dos nomes e das coisas, as relações entre nomes e nomes, coisas e 
coisas, e a religião geral, nova, renova, cabeças, entranhas, dedos. Aquilo que se equaciona - "de De", destruição nos subúrbios de Buenos Aires, Borges, "tahafut-ultahafiit" -, já a conversa fora da razão achada não pode repudiar. Esta nesta carta marítima, no roteiro de "maar", onde se lê, de maré a maré, o naufrágio do cruzeiro organizado pela agência Abreu. O almagre, elemento terra, transmuda-se; e os quatro elementos exaltados participam na crisopeia. É tudo inteligível na vista que da natureza se mudou para o athanor. Desde a última aurora ao primeiro crepúsculo, o cuidado universal quotidiano não concebera Blake no jardim de sua casa, tocado para sempre pela mão persuasiva e poderosa de uma Big Mother, a registar o cancioneiro que diz: a inocência conduz à ciência. Agora temos do novo o "Maar" que "em movimento inverso se expande", quer dizer: "O espaço come porém não altera". Ao cume serigráfico de uma espécie do montanha - pedra central com raiz na matéria negra subiu uma estrela de ouro; dinâmica: a mão superior que refulge, que protege o mundo, "sombra de almagre”. Cesariny contempla de lado, para lá de portuguesmente, por cima em forma de pálpebra cinza, de nuvem com toque amarelo, fora disto que é verde-rubro como as melancias. $\mathrm{O}$ poema lembrar-me-ia, se lembrasse, a canção de sageza infantil intacta que fala de um leão atrás da porta. Julgo tratar-se do leão vermelho dos alquimistas.

(In: A Phala, “de S. Jerónimo a Cesariny”. Lisboa: Assírio \& Alvim, 1\# 2007, p. 5458) 
ANEXO J - Cartaz da exposição de Cruzeiro Seixas na Galeria de Arte Moderna

\section{CRUZEIRO SEIXAS}

Desenho/Colagem/Objecto (1946-82)

28 de Maio - 17 de Junho 1982
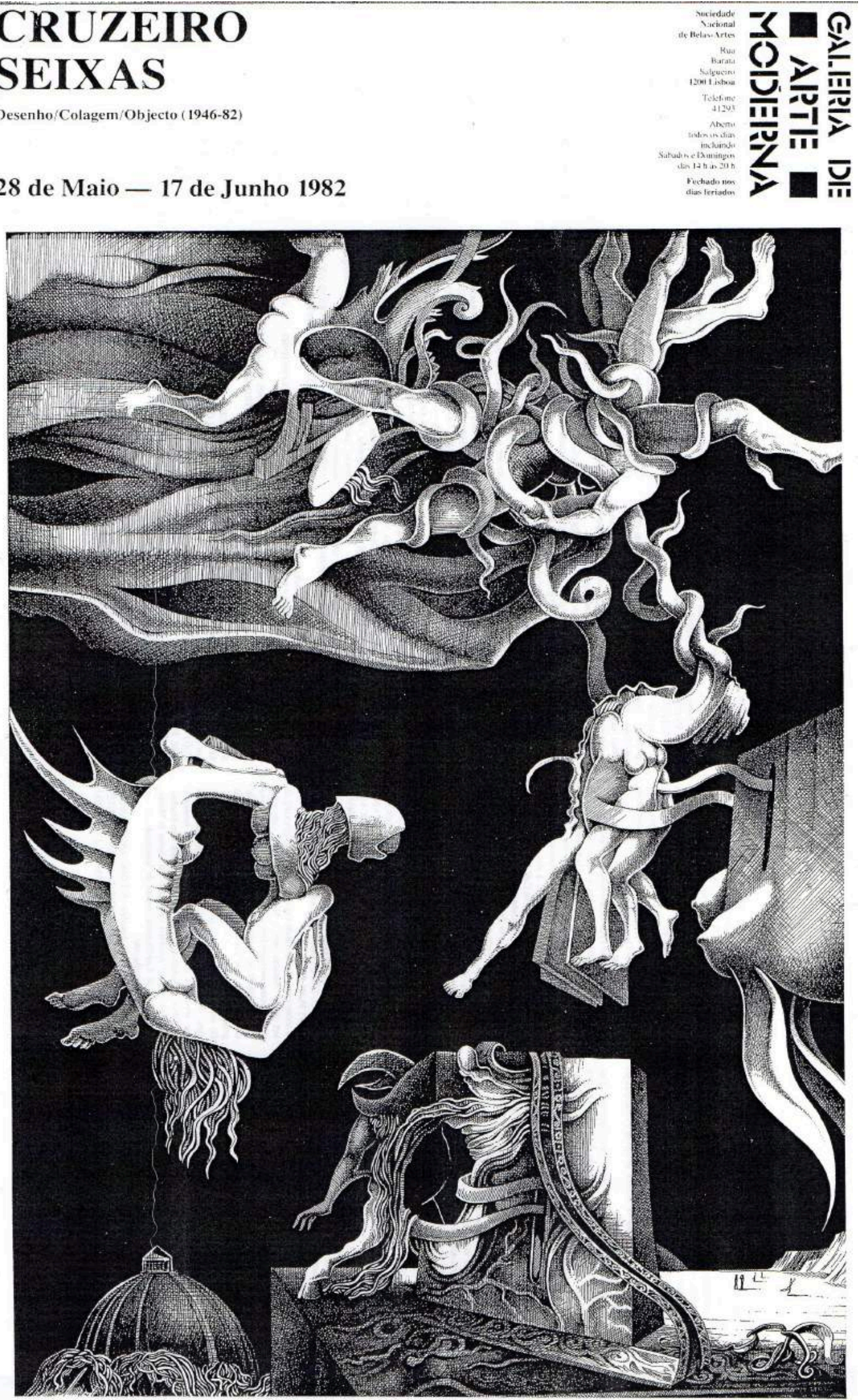

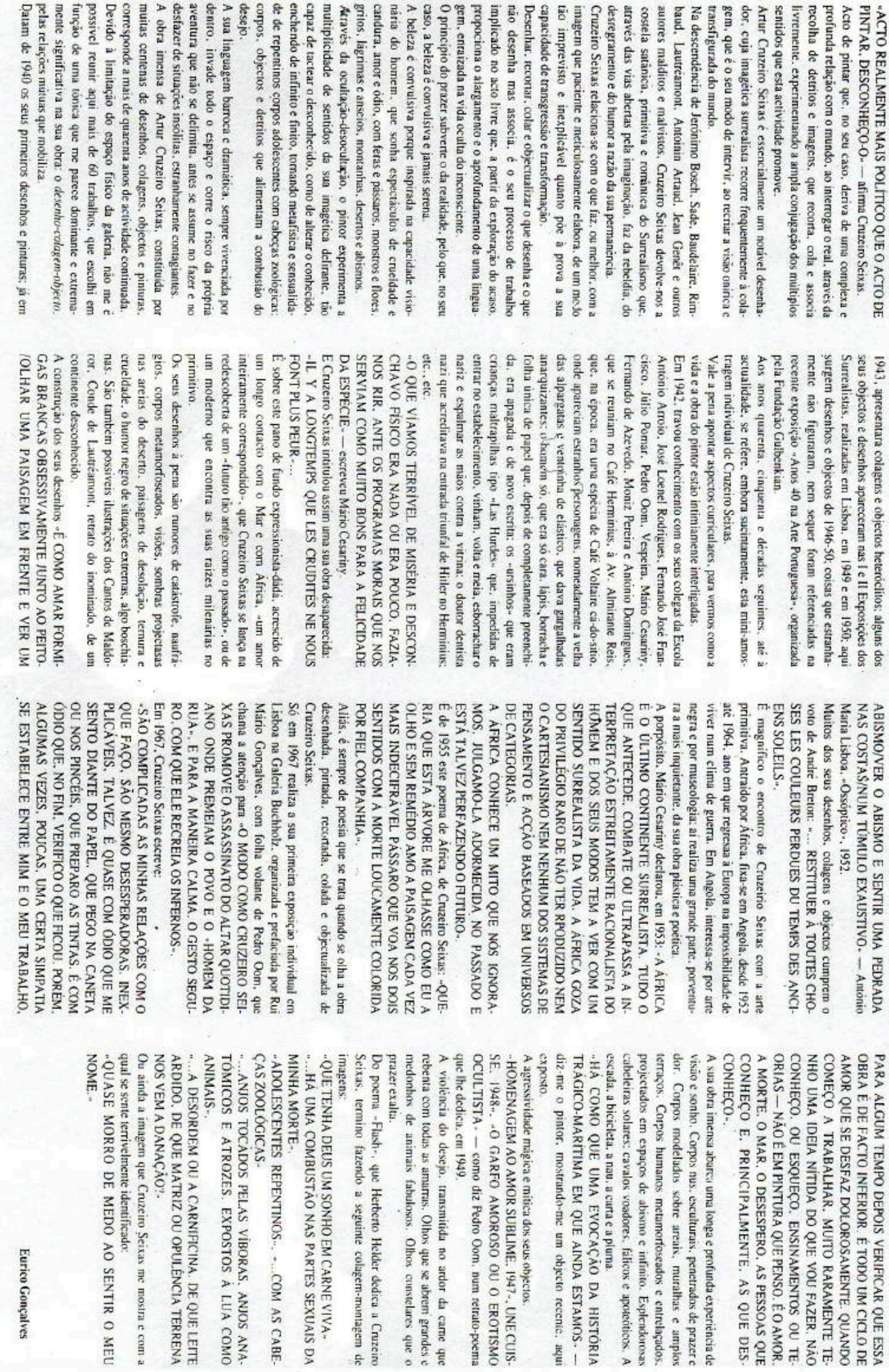